UNIVERSIDADE DE SÃO PAULO INSTITUTO DE GEOCIÊNCIAS

\title{
ZONA DE CISALHAMENTO RIBEIRA: DEFORMAÇÃO, METAMORFISMO E TERMOBAROMETRIA DE VEIOS SIN- TECTÔNICOS
}

FREDERICO MEIRA FALEIROS

Orientador: Prof. Dr. Ginaldo Ademar da Cruz Campanha

DISSERTAÇÃO DE MESTRADO

COMISSÃO JULGADORA

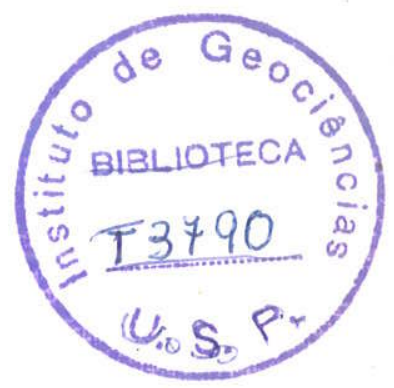

Nome

Assinatura

Presidente: Prof. Dr. Ginaldo Ademar da Cruz Campanha

Examinadores: Prof. Dr. Marcos Egydio da Silva

Prof. Dr. Peter Christian Hackspacher

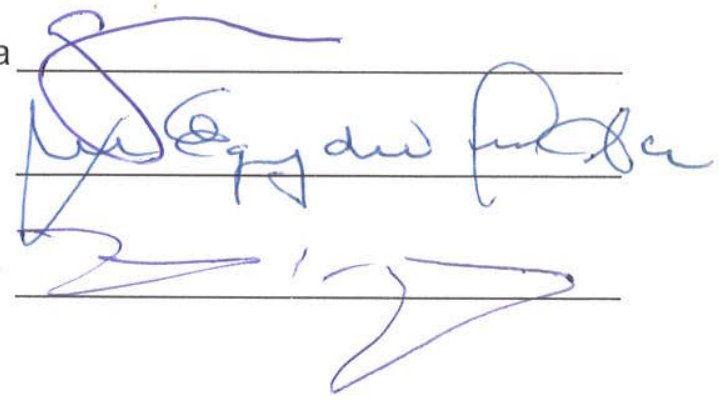

SÃO PAULO

2003 


\section{UNIVERSIDADE DE SÃO PAULO INSTITUTO DE GEOCIÊNCIAS}

\section{ZONA DE CISALHAMENTO RIBEIRA: DEFORMAÇÃO, METAMORFISMO E TERMOBAROMETRIA DE VEIOS SIN-TECTÔNICOS}

Frederico Meira Faleiros

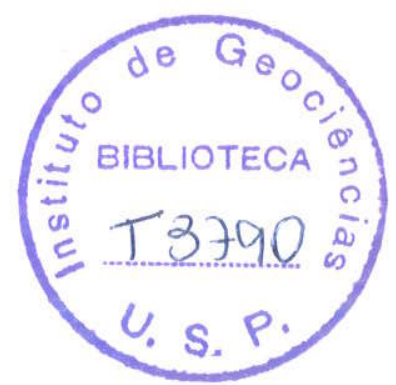

Orientador: Prof. Dr. Ginaldo Ademar da Cruz Campanha

DISSERTAÇÃO DE MESTRADO

Programa de Pós-Graduação em Geoquímica de Geotectônica

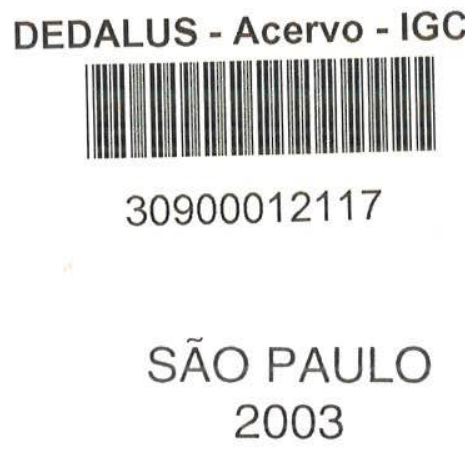




\section{RESUMO}

A Zona de Cisalhamento Ribeira, de natureza transcorrente destral e direção ENE, apresenta grande importância no zonamento metamórfico e estrutural do Supergrupo Açungui, no Vale do Ribeira (SP e PR). Dados petrográficos e microestruturais indicam uma longa história deformacional da zona de cisalhamento que é caracterizada por milonitos formados em condições desde fácies anfibolito $\left(550-600^{\circ} \mathrm{C}\right)$ até xisto verde $\left(300-400^{\circ} \mathrm{C}\right)$, seguido pela geração de brechas cataclásticas, veios de quartzo tardios e pela instalação de fraturas na qual inclusões fluidas tardias foram aprisionadas em condições de $85-150^{\circ} \mathrm{C}$. Estimativas de pressão e temperatura em grupos de inclusões presentes em veios de quartzo de diferentes gerações indicam que as movimentações finais ocorreram em uma trajetória de resfriamento quase isobárico.

As relações geométricas entre quatro familias principais de zonas de cisalhamento regionais com orientações NE, ENE, NNE e NE-ENE, aliadas aos padrões de foliações e lineações de estiramento e à distribuição espacial dos elipsóides de deformação não favorecem a aplicação dos modelos transpressivos numa hipótese de geração concomitante destas estruturas. A integração dos dados existentes sobre a história deformacional suportam a hipótese de uma evolução tectônica progressiva vinculada com convergência obliqua entre placas, caracterizada por três estágios principais. Inicia-se um estágio compressivo no qual foram geradas falhas de empurrão e macrodobras de orientação NE. Segue-se a instalação de transcorrências com orientação ENE, reativações direcionais das falhas NE e geração de transcorrências NNE. O estágio final foi caracterizado pelos movimentos tardios controlados pelo cisalhamento paralelo à borda da placa, representados pela Zona de Cisalhamento Lancinha.

As texturas e estruturas dos principais tipos de sistemas de veios de quartzo associados à Zona de Cisalhamento Ribeira, que são extensionais e paralelos à foliação milonítica, indicam que estes foram gerados em estágios cíclicos repetitivos com alternâncias entre processos de crescimento e deformação. Ambos os tipos de veios foram gerados em condições subsolvus sob flutuação da pressão, na presença de fluidos aquocarbônicos e, posteriormente, deformados na presença de fluidos aquossalinos de menores temperaturas. O fluxo de fluidos geral pela Zona de Cisalhamento Ribeira é caracterizado por pulsos de fluidos aquocarbônicos primitivamente ricos em metano que evoluem no sentido de perda deste componente e de um leve enriquecimento em nitrogenio. Esses pulsos se alternaram no tempo com pulsos aquossalinos. A integração dos dados mostra-se favorável à aplicação do modelo de bombeamento sísmico como mecanismo responsável pelo transporte e redistribuição de fluidos durante a ativação de falhas. 


\section{ABSTRACT}

The Ribeira Shear Zone, in the homonymous valley, Southeast Brazil is a dextral transcurrent, ENE trending structure. It was a fundamental role in the metamorphic and structural zoning of the Açungui Supergroup. Petrographic and microstructural data indicate a long deformational history of the shear zone which is characterized by mylonites formed under amphibolite $\left(550-600^{\circ} \mathrm{C}\right)$ to green-schist $\left(300-400^{\circ} \mathrm{C}\right)$ facies conditions, followed by cataclastic breccias and late quartz-veins formation and fracture installings in which late secondary fluid inclusion trails were formed at $85-150^{\circ} \mathrm{C}$. Pressure and temperature estimatives from fluid inclusion groups of the different quartz-veins generations indicate that late shear zone movements occurred during nearly isobaric cooling.

Geometric relationships between the four main regional shear zone sets with NE, ENE, NNE and NE-ENE trends together with foliations and stretching lineations patterns and spatial distribution of deformation ellipsoids do not favour the applications of transpressive models in a hypothesis of contemporaneous generation of these structures. Data support the hypothesis of progressive tectonic evolution associated with oblique convergence between plates characterized by three main stages. The first was compressive during which northeast trending thrust faults and regional folds were developed. In the second stage, dextral ENE and sinistral NNE trends strike-slip shear zones were formed and NE-thrust faults were reactived with a sinistral transcurrent character. The late stage was characterized by displacements controlled by shearing parallel to the plate boundary, represented by the Lancinha Shear Zone.

Textures and structures of the two main quartz-vein systems associated with the Ribeira Shear Zone, which are extensional and parallel to mylonitic foliations, indicate that they were formed in cyclic stages alternating growth and deformation. Both types of veins were formed in subsolvus conditions under pressure fluctuations, in the presence of aqueouscarbonic fluids, and were deformed in the presence of lower temperature aqueous-saline fluids. The general fluid flow is characterized by aqueous-carbonic fluid pulses initially methane-rich that underwent progressive lose of methane and a small gain of nitrogen. These pulses alternated in time with aqueous-saline fluid pulses. Data are favorable to application of the seismic pumping model as a mechanism of transport and redistribution of fluids during faults activation. 


\section{ÍNDICE}

1. INTRODUÇÃO

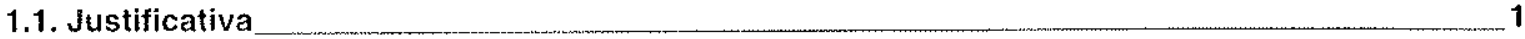

1.2. Objetivos 2

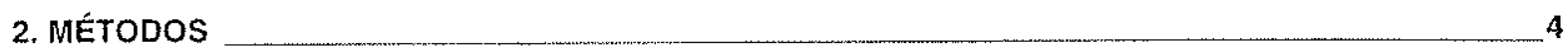

3. TRABALHOS ANTERIORES

4. COMPARTIMENTAÇÄO TECTONNICA ____ 11

5. PETROGRAFIA E ESTRUTURAS DAS ROCHAS DE FALHA ___ 21

5.1. Feiçöes Macroscópicas ___ 21

5.2. Microestruturas e Mineralogia Metamórfica 25

5.3. Discussão _ 37

6. ANÁLISE GEOMÉTRICA ___ 42

6.1. Classificação dos Principais Lineamentos Regionais ___ 42

6.2. Padrão de Isógonas ____ 44

6.3. Orientação das Foliações e Lineações

7. INDICADORES CINEMÁTICOS

8. ANÁLISE DA DEFORMAÇÃO FINITA ___ 59

8.1. Base Teórica ___ 59

8.1.1. Método de Orientação Preferencial de Forma ___ 59

8.1.2. Método $R_{1} / \varnothing^{\prime}$

8.1.3. Cálculo de elipsóides a partir das elipses de três seções perpendiculares _____ 63

8.2. Procedimentos adotados 64

8.3. Discussão 65

9. TRAMAS DE EIXO-C DE QUARTZO 80

9.1. Introdução____ 80

9.2. Petrografia das rochas de falha analisadas ___ 80

9.3. Descrição das tramas de eixo-c de quartzo

9.4. Discussäo _..._. 83

10. INCLUSÕES FLUIDAS E ESTRUTURAS DE VEIOS DE QUARTZO

10.1. Características Estruturais dos Veios de Quartzo _ 91

10.2. Inclusōes Fluidas - Método Analítico

10.3. Petrografia das Inclusões Fluidas ___ 95

10.4. Microtermometria ______ 98

10.5. Espectroscopia Raman ___ 101

10.6. Discussão ___ 101

10.7. Conclusões _ 115

11. CONSIDERAÇÕES FINAIS _________ 129

11.1. Evolução Metamórfica _________ 129

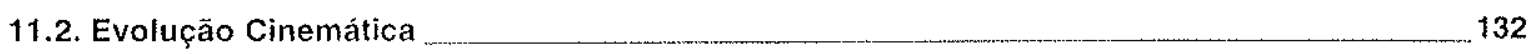

12. CONCLUSÕES 136

13. REFERÊNCIAS BIBLIOGRÁFICAS

AGRADECIMENTOS ___ 145 


\section{ÍNDICE DE FIGURAS}

Figura 1.1. Localização

Figura 4.1. Compartimentação Tectônica 13

Figura 4.2. Mapa Geológico Simplificado

Figura 5.1. Ilustraçöes fotográficas de feiçöes de campo

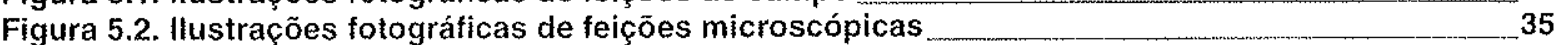

Figura 5.3. Hlustrações fotográficas de feições microscópicas ____ 36

Figura 5.4. Diagrama $P$ versus $T$ com reações metamórficas de metapelitos e metabasitos _..__ 40

Figura 6.1. Classificação dos principais lineamentos regionais

Figura 6.2. Padrão de isógonas mostrando relaçōes angulares _ $\quad 45$

Figura 6.3. Padrão de isógonas e representação das principais zonas de cisalhamento _. $\quad 46$

Figura 6.4. Interpretação do padrão de superposição de deformaçöes ______ 47

Figura 6.5. Anatise geométrica de foliações e lineaçōes de estiramento da ZCR _ _

Figura 6.6. Analise geométrica de fraturas da ZCR

Figura 6.7. Analise geométrica de foliaçōes e lineações de estiramento das ZC ___ 54

Figura 7.1. llustrações fotográficas de indicadores cinemáticos _ـ___n 57

Figura 7.2. modelos de pares de foliaçōes $\mathrm{SC}, \mathrm{SC}_{1}$ e $\mathrm{SC}_{2}$

Figura 7.3. modelo do par de foliações $\mathrm{SC}_{1} \ldots$

Figura 8.1. Objeto teórico em formato raster no método OPF 61

Figura 8.2. Gráficos Rf/Phi teóricos __________._._. 61

Figura 8.3. Orientação das seções e subseções de análise da deformaçäo finita ___ 61

Figura 8.4. Gráficos Rf/Phi e subseçŏes correspondentes da amostra M51_______ 68

Figura 8.5. Gráficos Rt/Phi e subseçōes correspondentes da amostra M183 69

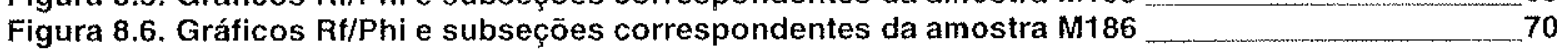

Figura 8.7. Gráficos Rf/Phi e subseções correspondentes da amostra M193A ___

Figura 8.8. Gráficos Rf/Phi e subseçōes correspondentes da amostra M193B

Figura 8.9. Gráticos Rt/Phi e subseções correspondentes da amostra M206A ______

Figura 8.10. Gráficos Rt/Phi e subseçöes correspondentes da amostra M215__

Figura 8.11. Gráficos Rf/Phi das amostras F198 e M23 e subseçăo desta última ___ 75

Figura 8.12. Diagrama de Flinn com dados obtidos

Figura 8.13. Estereogramas com eixos principais dos elipsóides de deformação

Figura 8.14. Mapa de distribuição das orientações dos elipsóides de deformação ___.__ 79

Figura 9.1. Tramas de eixo-c obtidas ___ 82

Figura 9.2. Diagrama de Flinn com representação das tramas de eixo-c teóricas _................ 82

Figura 9.3. Tramas cristalogräficas não-coaxiais teóricas _._. 82

Figura 10.1. Critérios de fraturamento extensional e por cisalhamento ___ 90

Figura 10.2. Expressão do fraturamento hidráulico 90

Figura 10.3. Ilustraçöes fotográficas de veios paralelos e extensionais ___ 117

Figura 10.4. Mapa de amostragem $\quad 117$

Figura 10.5. llustraçóes fotográficas de inclusões fluidas _. 118

Figura 10.6. Histogramas microtermométricos das inclusöes dos grupos A e C

Figura 10.7. Histogramas microtermométricos das inclusões dos grupos $B, C$ e $E \ldots$

Figura 10.8. Histogramas microtermométricos das inclusöes do grupo D _ _ _ 121

Figura 10.9. Histogramas microtermométricos das inclusões do grupo $F \quad 122$

Figura 10.10. Histogramas microtermométricos das inclusões do grupo $1 \ldots 123$

Figura 10.11. Histogramas microtermométricos das inclusōes do grupo 2

Figura 10.12. Resultados de espectroscopia Raman __.......... 125

Figura 10.13. Diagramas salinidade versus preenchimento, $T f_{\mathrm{CO} 2}$ versus $T_{\mathrm{CO} 2}$ (Grupo $\left.A\right) \ldots$

Figura 10.14. Diagrama Th versus Ts (Grupo B) $\quad 126$

Figura 10.15. Diagrama $\mathrm{Tf}_{\mathrm{CO} 2}$ versus $\mathrm{Th}_{\mathrm{CO} 2}(\mathrm{Grupo} F)$

Figura 10.16. Diagramas salinidade versus preenchimento, $\mathrm{Tf}_{\mathrm{CO} 2}$ versus $\mathrm{Th}_{\mathrm{CO} 2}$ (Grupo 1) _______ 126

Figura 10.17. Diagramas isocóricos com campos de pressão estimados ___ 127

Figura 10.18. Modelo alternativo de formação dos veios paralelos à foliação milonítica _ $\quad 128$

Figura 11.1. Trajetórias de pressão e temperatura da ZCR

Figura 11.2. Modelo tectônico para área de estudos ___ 135 


\section{ÍNDICE DE TABELAS}

Tabela 5.1. Proporções entre as fases minerais de xistos/filitos 26

Tabela 5.2. Relações entre os minerais metamórficos e as foliações em metassedimentos 29

Tabela 5.3. Proporções entre as fases minerais de metabasitos 30

Tabela 5.4. Relações entre os minerais metamórficos e as foliações nos metabasitos. 32

Tabela 5.5. Proporçōes entre as fases minerais de calciossilicáticas 32

Tabela 5.6. Proporções entre as fases minerais de granitóides 34

Tabela 8.1. Comparação entre os resultados bidimensionais de $R_{S}$ obtidos pelos três métodos. 66

Tabela 8.2. Comparação entre os resultados $3 D$ obtidos por $O P F, R_{t} / \varnothing^{\prime}$ e média harmônica 67

Tabela 10.1. Sintese dos resultados microtermométricos 102

Tabela 10.2. P e T de aprisionamento estimadas nos grupos de inclusões fluidas 110

\section{ANEXOS}

Anexo 1. Mapa Geológico

Anexo 2. Perfil Geológico

Anexo 3. Mapa de pontos de descriçäo de afloramentos 


\section{INTRODUÇÃO}

A Zona de Cisaihamento Ribeira (ZCR) encontra-se inserida no importante sistema de cisalhamento de direção ENE que corta rochas pré-cambrianas no sudeste e sul do Brasil. Possui notável expressão vista em imagens de sensores remotos e fotografias aéreas, infletindo as estruturas regionais por quilômetros a dezenas de quilômetros. Secciona rochas metamórficas do Supergrupo Açungui e granitóides nele intrusivas.

$\mathrm{Na}$ sua extremidade leste une-se com a Falha da Lancinha, que por sua vez ligase com a Falha de Cubatão-Além Paraiba, tida como o principal timite litosférico de toda a Faixa Ribeira. Na sua extremidade oeste une-se ao Lineamento de Morro Agudo, que vem com direção NNE, passando a ter essa denominação no Estado do Paraná (Fig. 1.1).

Apesar da grande expressão regional a ZCR é de difícil caracterização no campo, principalmente quando corta rochas metassedimentares de baixo grau, onde desenvolve filonitos. Quando afeta rochas mais competentes, tais como anfibolitos, quartzitos e granitóides, desenvolve rochas miloníticas e cataclásticas.

\subsection{Justificativa}

A notável proeminência das deflexões regionais entorno da ZCR, bem como a existência de blocos tectônicos (a norte) com marcadores de deformaçăo confiáveis (reliquias de estruturas sedimentares primárias), fornece uma boa oportunidade de avaliação dos processos de formação de zonas de cisalhamento e dos padrões de foliações e lineações geradas.

A caracterização do metamorfismo e do nivel crustal das rochas presentes nos blocos tectônicos separados pelas zonas de cisathamento é de grande importância na definição dos possiveis modelos cinemáticos em que estas estruturas puderam ser geradas.

Sistemas de veios associados com movimentações de falhas podem ser considerados como produtos fósseis exumados de atividade sismica e proporcionam uma boa evidência do envolvimento de fluidos durante falhamentos, uma vez que, tais veios são marcadores do fluxo de fluidos. Dessa forma, a ocorrência de sistemas de veios de quartzo bem expostos, associados à ZCR, proporciona uma oportunidade de avaliação da importância e dos efeitos da pressão de fluidos ao longo de falhas ativadas 
sismicamente, além de fornecer informações sobre a circulação de fluidos em larga escala e sua redistribuição na crosta. As condições $P$ e $T$ de formação dos veios são também relacionadas com as últimas etapas do metamorfismo regional.

A caracterização das condições $P$ e $T$, bem como dos fluidos presentes tem também implicações em termos de possíveis mineralizações associadas à zonas de cisalhamento. Na região a ocorrência de ouro em veios de quartzo das regiões de Piririca e Ivaporunduva são tidas como associadas a zonas de cisalhamento subsidiárias da ZCR (Nogueira, 1990; Câmara, 1992; Perrota, 1996). A ocorrência de fluorita na mina de Sete Barras pode estar associada a fases de movimentação da ZCR (Campanha, 2001).

\subsection{Objetivos}

Os objetivos do trabalho foram:

(1) Caracterização estrutural da ZCR em termos de sua geometria e cinemática;

(2) Caracterização das condições metamórficas em que as deformações ocorreram;

(3) Geotermobarometria e caracterização de fluidos em sistemas de veios de quartzo;

(4) Elaboração de modelos de deformação e metamorfismo para área de estudos;

(5) Contextualização das informações obtidas em termos do sistema regional das zonas de cisalhamento do Domínio Apiaí, e da evolução dos blocos adjacentes. 


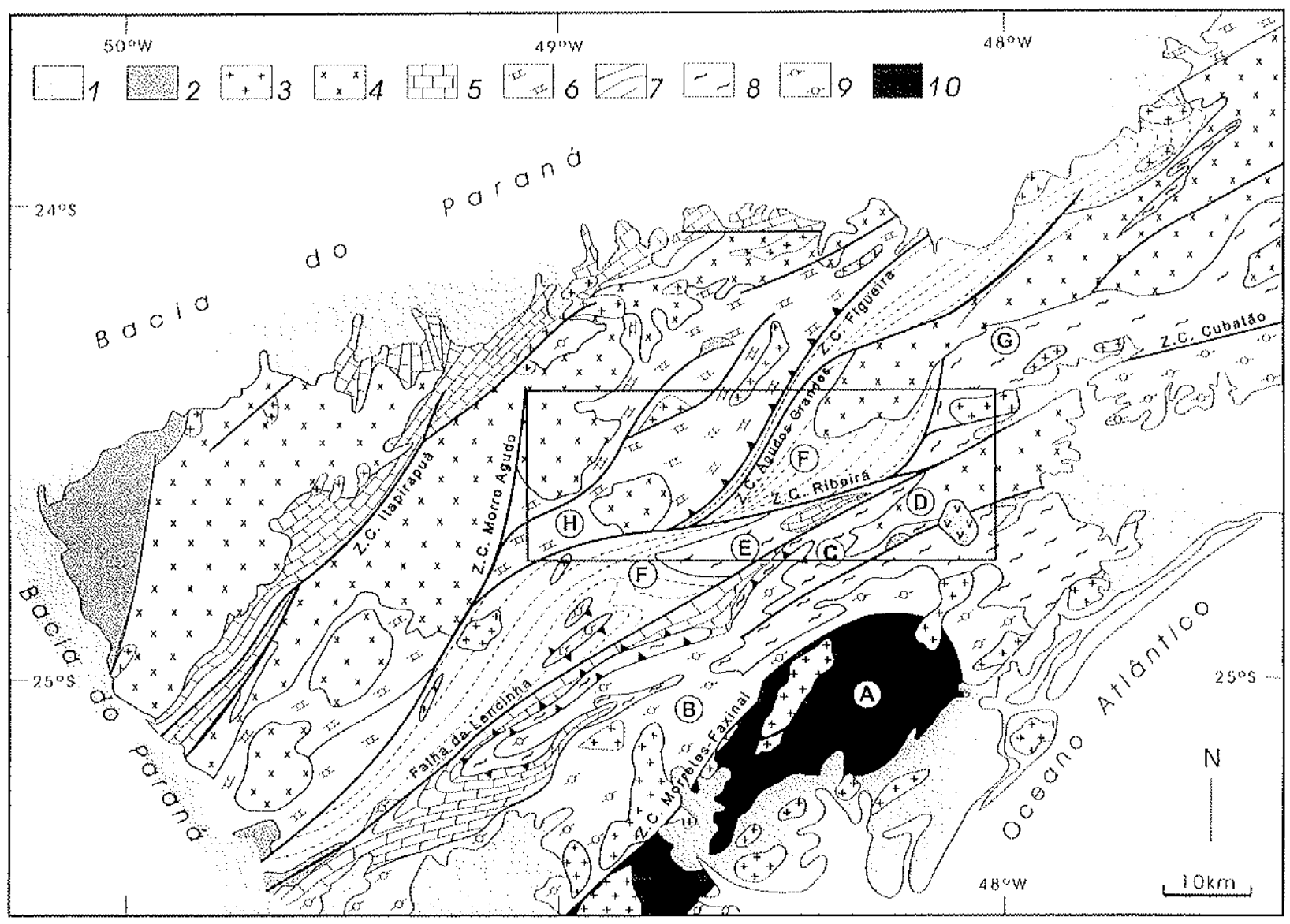

Figura 1. Mapa tectônico simplificado do Domínio Apiaí da Faixa Ribeira. Adaptado de Campanha \& Sadowski (1999).

Principais dominios tectônicos e paleogeográficos

1- coberturas e rochas intrusivas de idades fanerozóicas

2 - bacias molassóides tardias

3- granitos pós-tectônicos

4. granitos sin a tardi-tectônicos

5- plataformas carbonáticas de águas rasas

6- plataformas carbonáticas distais

7- seqüencias metaturbidíticas, metavulcânicas e metapelágicas

8- xistos de ambientes desconhecidos

9- gnaisses migmatíticos

10-gabros-noritos, charnockitos

Principais unidades litoestratigráficas relacionadas com o trabalho proposto
A- Complexo Serra Negra ou Alto Turvo
B. Complexo Gnáissico-Migmatítico
C- Seqüencia Turvo-Cajati
D- Maciço de ltapeúna
E. Seqüência Serra das Andorinhas
F- Subgrupo Ribeira indiviso
G- Complexo Embu
H- Subgrupo Lajeado
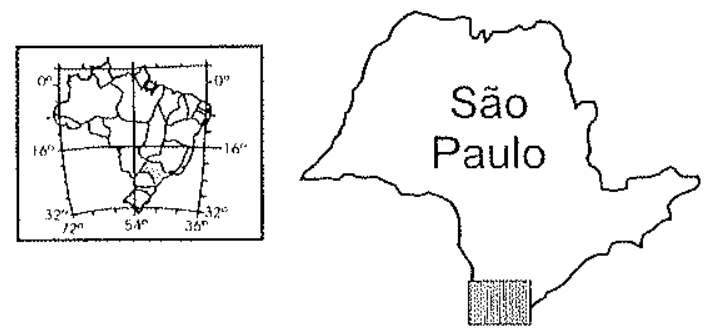


\section{MÉTODOS}

Abaixo são descriminados sucintamente os procedimentos utilizados para atingir os objetivos. Tais métodos encontram-se descritos com detalhe em cada capítulo específico.

\subsection{Análise Geométrica e Cinemática}

(1) interpretação de fotos aéreas em escala 1:60.000;

(2) compilação e integração de produtos cartográficos incluindo dados estruturais, pontos de descrição de afloramentos, amostras e ensaios anteriormente realizados;

(3) caminhamentos de campo transversais às estruturas regionais e ao longo da Zona de Cisalhamento Ribeira, além de perfis detalhados em regiőes selecionadas;

(4) caracterização cinemática através da interpretação de dados de campo, tais como lineações, foliações e indicadores cinemáticos;

(5) caracterização cinemática através da análise da geometria das estruturas defletidas (isógonas) e da correlação entre niveis estratigráficos;

(6) análise de tramas de rochas cisalhadas, pela orientação preferencial de forma de minerais e orientação preferencial de eixo-c de quartzo.

\subsection{Caracterização Metamórfica}

(1) Descrição petrográfica de seções delgadas, visando definir os mecanismos de deformação atuantes e reconhecer as paragêneses metamórficas;

(2) estimativas de temperatura de metamorfismo por meio da interpretação dos sistemas de deslizamentos intracristalinos ativados na deformação de grãos de quartzo, responsáveis pela produção das tramas cristalográficas de eixo-c.

(3) geotermobarometria de veios de quartzo e caracterização de fluidos por meio de análises em inclusões fluidas (microtermometria e espectroscopia Raman). 


\section{TRABALHOS ANTERIORES}

\subsection{Evolução dos conhecimentos na área}

Desde o início do século XIX o Vale do Ribeira tem sido alvo de diversos trabalhos versando sobre geologia, tanto nos estado de São Paulo como do Paraná. Esse interesse decorreu da grande importância econômica das rochas da região e resultou em uma enormidade de denominações formais e informais que acabou tornando confuso o entendimento da estratigrafia do Grupo Açungui. Da vasta gama de trabalhos presentes na literatura geológica, distingem-se aqueles de caráter bastante gerais, aqueles que abordam aspectos relacionados com a gênese de mineralizações diversas, os de cunho sedimentar e os de enfoque tectônico.

Dentre os trabahos pioneiros citam-se os de Derby (1878), que descreveu genericamente os metamorfitos do Vale do Rio Açungui, e os trabalhos de Oliveira (1916, 1925, 1927) que introduziu o termo Série Açungui, separando as rochas metassedimentares da região oeste e noroeste de Curitiba, de um embasamento tido como Arqueano.

Moraes Rego (1933) denominou de Série São Roque os epimetamorfitos que reconheceu nas proximidades da cidade de São Paulo. Posteriormente essa série foi considerada contínua com a Série Açungui (Carvalho \& Pinto, 1937; Martins, 1938), sendo utilizado um ou outro nome conforme o autor.

Barbosa (1941) propôs a primeira subdivisão estratigráfica para a chamada Série São Roque, na região entre Apiaí e Iporanga. Outra subdivisão estratigráfica para essa região foi proposta por Geoffrey \& Santos (1942).

Barbosa (1948) apresentou o primeiro perfil geológico completo levantado na estrada Apiai-lporanga. No mesmo trabalho priorizou, para a designação dos metamorfitos da bacia do Ribeira, a utilização do termo Série Açungui, ao termo Série São Roque, argumentando serem ambas uma única e a mesma unidade geológica e a designação Série Açungui ser mais antiga.

Tentativas sistemáticas de subdivisões estratigráficas para o Grupo Açungui iniciam-se nas décadas de 50 na porção paranaense (e.g. Bigarella \& Salamuni, 1956a, b; Bigarella \& Salamuni, 1958a, b; Marini et al., 1967), e de 70 na porção paulista (e.g. Algarte et al., 1974; Morgental et al., 1975; Silva et al., 1977, 1978).

Entre as décadas de 70 e 90 a região foi alvo de diversos mapeamentos geológicos em escalas regionais (Algarte et al., 1974; Silva et al., 1981; Silva \& Algarte, 1981a, b; Campanha et al., 1988) e de semi-detalhe (MMAJ/JICA, 1981, 1982, 1983; 
Campanha et al., 1985; Vasconcelos et al., 1999). Esses trabalhos contribuíram muito para o entendimento da evolução geológica no Vale do Ribeira.

Dos trabalhos com enfoque sedimentológico destacam-se os de Petri \& Suguio (1969) que interpretaram o ambiente de sedimentação do Grupo Açungui, como representando uma bacia marinha com sedimentação não litorânea próxima à linha de costa, com aumento progressivo da profundidade das águas de noroeste para sudeste. Posteriormente Pires $(1988,1990,1991)$ apresentou uma concepção dos ambientes de sedimentação do Grupo Açungui através da identificação e análise de seqüências deposicionais. Identificou na região entre Apiai e Barra do Turvo, cinco seqüências deposicionais e um complexo turbiditico, refletindo episódios transgressivos e regressivos e diferentes ambientes de sedimentação.

Com enfoque tectônico destacam-se os trabalhos de Fiori (1985a, b), Campanha et al. (1987), Soares (1987), Ebert et al. (1988), Fiori (1993), Fassbinder (1990), Campanha (1991), Fassbinder et al. (1994), Reis Neto (1994), Fassbinder (1996), Campanha \& Sadowski (1999) e Campanha \& Sadowski (2002).

\subsection{Zonas de Cisalhamento do Vale do Ribeira}

A parte meridional da Faixa de Dobramento Ribeira (Domínio Apiaí), localizada no vale homônimo (estados de São Paulo e Paraná), é cortada por grandes lineamentos que correspondem a zonas de cisalhamento de várias naturezas. Essas zonas de cisalhamento influenciam a compartimentação litoestrutural e faciológica da região. Nesse âmbito podem ser destacados como os mais importantes os lineamentos Carumbé, Quarenta-Oitava, Itapirapuã, Figueira, Agudos Grandes, Morro Agudo, Ribeira, Lancinha e Cubatão. Esses lineamentos afetam rochas metassedimentares pertencentes ao Supergrupo Açungui e rochas granitóides sin a tardi-tectônicas.

O Lineamento Ribeira foi identificado por Algarte et al. (1974). Segundo os autores este afeta rochas plásticas (filitos e xistos), que funcionam como elementos dispersores dos esforços através dos seus inúmeros planos de foliação. Os autores relataram que a provável continuidade do Lineamento Ribeira seria o traço definido pela convergência das falhas Cubatão e Itariri.

Algarte et al. (1974) denominaram de Falha de Morro Agudo, zonas de rochas cataclásticas de direção geral N10E que cortam o granito Três Córregos.

Para Sadowski (1983) o prolongamento da Falha de Cubatão-Além Paraíba se daria ou segundo o Lineamento Ribeira ou Segundo a Falha da Lancinha, sendo a última 
hipótese mais provável. Assim, a Falha de Além Paraíbam-Cubatäo-Lancinha alcançaria mais de $820 \mathrm{Km}$ de extensão.

Sadowski $(1983,1984)$ reconheceu que a Zona de Falhamento Ribeira apresenta nítido arrasto destral visivel em fotografia aérea e imagens Landsat. Observou juntas antitéticas $R^{\prime}$ na região de Barra do Batatal, próximo a Iporanga e estimou valores de deslocamento horizontal mínimo de $10 \mathrm{~km}$ ao longo do Lineamento Ribeira, nestas proximidades.

Fassbinder et al. (1985) dividiram o sistema de falhas do pré-Cambriano paranaense da seguinte forma:

- Sistema NE: formado por falhas transcorrentes principais com movimentação destral, situadas sobre antigas zonas de fraqueza do embasamento. São exemplo desse sistema as falhas Lancinha, Morro Agudo e Itapirapuã;

- Sistema ENE: formado por falhas ou fraturas secundárias sintéticas, de movimentação destral. A Faiha da Ribeira seria a mais importante inserida nesse sistema;

- Sistema NW: formado por falhas ou fraturas secundárias antitéticas, com movimentação sinistral;

- Sistema NNW: relacionado a outro sistema de esforços mais jovem, ou representado por fraturas de relaxamento associadas ao modelo discutido.

Alguns autores propöem que as falhas principais (expostas no modelo acima), são reflexos de reativação de falhas antigas do embasamento cristalino atingindo a cobertura metassedimentar representada pelo Grupo Açungui (Fiori, 1985a, b, c; Fassbinder et al. 1985).

Fiori (1985a) utilizando o modelo de cisalhamento simples de Ramsay \& Graham (1970), calculou um deslocamento dúctil destral médio para as falhas da Lancinha e Morro Agudo de $114 \mathrm{~km}$ e $106 \mathrm{~km}$, respectivamente.

Fassbinder (1990) constatou que as falhas Ribeira, do Cerne e demais de direção ENE provocaram uma movimentação destrógira nas falhas/fraturas de direção NNE, como as da Figueira e Agudos Grandes, entre outras. Segundo o autor as falhas NNE constituem normalmente limites laterais NW e SE de macrolentes tectônicas, que apresentam um formato de paralelogramo com suas terminações NE e SW infletidas, indicando movimento lateral direito ao longo das falhas ENE.

Sadowski (1991) nomeia todo o conjunto de falhas transcorrentes que rodeiam a costa sudeste brasileira como Sistema de Falhamento Cubatão ou Megafalha de Cubatão, que seria segmentado pelas três falhas principais de nordeste para sudoeste, 
Além-Paraiba, Cubatão e Lancinha. Segundo o autor esse sistema abrange uma área exposta em torno de $800 \mathrm{~km}$ e mais $1200 \mathrm{~km}$ de área sob as rochas sedimentares da bacia do Paraná, totalizando aproximadamente $2000 \mathrm{~km}$ de extensão. Na mesma seqüência apresentada para as três falhas, teriamos a representação de nivel crustal profundo a NE, passando de médio em direção SW até chegar ao nível superior. $O$ autor cita uma evolução cinemática extremamente complexa dessa zona de cisalhamento, passando desde falhamento inverso até transcorrente destral e sinistral, bem como normal a obliquo.

Campanha et al. (1993) e Campanha \& Sadowski (2002) analisaram, através do traçado de isógonas, as estruturas regionais do Supergrupo Açungui infletidas ao longo de um trecho do Lineamento Ribeira. Nesses trabalhos, identificaram um paralelismo das estruturas com o Lineamento Ribeira até a isógona de $25^{\circ}$, sendo de $10^{\circ}$ o menor ângulo entre as estruturas e o lineamento. As isógonas acima de $30^{\circ}$ são defletidas nas zonas de influência dos Lineamentos Agudos Grandes e Figueira, onde ocorre truncamento das estruturas sugerindo movimentação diferencial destas em relação ao Lineamento Ribeira. Nos mesmos trabalhos, os autores calcularam um rejeito total de $50 \mathrm{~km}$ para o Lineamento Ribeira, indicado pelas correlações litoestratigráficas e inflexão regional das estruturas no Bloco Lajeado. Desse rejeito total, no bloco norte, $16 \mathrm{~km}$ e $14 \mathrm{~km}$ são respectivamente os rejeitos dúctil e rúptil. No bloco sul foi calculado um rejeito dúctil de $20 \mathrm{~km}$. Para explicar o variado padrão de distribuição das isógonas, os autores atentaram para a alternância de pacotes com forte contraste de competência, ação de várias zonas de cisalhamento de dimensões menores e efeitos deformacionais causados pela intrusão do Granito Itaoca.

Perrota (1996) definiu duas falhas transcorrentes de direção geral NE-SW ocorrentes no bloco a norte do Lineamento Ribeira, denominadas de zonas de cisalhamento Ivaporunduva e Piririca. Segundo a autora os indicadores cinemáticos identificados sugerem movimentações destrais.

Mello (1995) e Mello \& Bittencourt (1998) apresentaram uma idade isocrônica $\mathrm{Rb} / \mathrm{Sr}$, em rocha total, de $626 \mathrm{Ma}$ para o Maciço Itaoca. Essa é uma idade minima de ativação da Zona de Cisalhamento Ribeira, que deforma a porção sul do batólito. Entretanto, Tassinari \& Mello (1994 apud Mello \& Bettencourt, 1998) obtiveram uma idade de 520 Ma para mineralizações de fluorita em filões associados à Zona de Cisalhamento Pavão, que afeta a porção leste do batólito. Essa foi considerada uma idade compativel com o intervalo admitido para os eventos de transcorrência regionais que teriam reajustado o sistema isotópico na passagem do Proterozóico para o Fanerozóico (Mello \& Bittencourt, 1998). 
Dos modelos cinemáticos mais relevantes para a explicação do cinturão de cisalhamento que afeta a área de estudos destacamos aqueles apresentados por Ebert et al. (1988), Fassbinder (1990), Fassbinder et al. (1994), Fiori (1993), Fassbinder (1996) e Campanha (2002).

Ebert et al. (1988) apresentaram um modelo transpressivo para a evolução do Cinturão Móvel Costeiro, a partir de estudos na Megantiforma da Serra do Cadeado, que representa um submbloco tectônico delimitado pelos lineamentos Lancinha, Ribeira e Morro Agudo. Segundo os autores a referida área teria sofrido três fases de deformação, iniciando com uma fase de deformação tangencial $D_{1}$, relacionada com cavalgamento obliquo para norte ou noroeste do Bloco Vitória sobre o Bloco São Paulo, responsável pela geração da maioria das estruturas regionais penetrativas, tais como a foliação metamórfica $S_{1}$. Com a evolução do processo, teria havido a atuação de uma tectônica tangencial mista e culminaria com uma deformação transpressiva $D_{3}$, que teria absorvido os esforços regionais por rotaçăo, deformação e dobramento de estruturas preexistentes ao longo das zonas de cisalhamento dúctil de alto a médio ângulo e de cavalgamento ao longo de zonas de baixo ângulo.

Fassbinder (1990) e Fassbinder et al. (1994) aplicaram o modelo de Riedel para a Zona de Cisalhamento Lancinha no estado do Paraná. Abaixo são citadas as principais estruturas interpretadas como decorrentes da movimentação da falha principal do sistema representada pela Zona de Cisalhamento Lancinha nesse modelo:

a) Zonas de cisalhamento sintéticas $(R)$ com direção média $N 85^{\circ} E$, tendo como melhores exemplos as zonas de cisalhamento Ribeira e do Cerne.

b) Zonas de cisalhamento e/ou fraturas antitéticas ( $\left.R^{\prime}\right)$ com direção ao redor de N10$30^{\circ} \mathrm{W}$, observadas como lineamentos em imagens de radar e como finas clivagens em escala de amostra de mão.

c) Familias de juntas de relaxamento $(X)$ e falhas de empurrão com direção entre N10$40^{\circ} \mathrm{E}$, sendo estas últimas interpretadas como duplex de Riedel. Os autores incluíram nesse grupo de estruturas as zonas de cisalhamento Espirito Santo, Figueira, Agudos Grandes e Caucáia.

Fiori (1993) definiu o Sistema de Cavalgamento Açungui que englobaria todas as estruturas geradas durante um primeiro evento deformacional do Grupo Açungui, anterior à instalação das transcorrências. Segundo o autor as principais estruturas geradas seriam falhas de cavalgamento, dobras de arrasto $D_{1}$, foliações $S_{1}$ (principal) e $S_{2}$.

Fassbinder (1996) elaborou um modelo transpressivo associado a colisão obliqua para deformação neoproterozóica das rochas no Estado do Paraná. Segundo o autor as 
formações Água Clara, Votuverava e Capirú teriam suas estruturações organizadas por componentes de deformação submetidas a partição em falhas de baixo ângulo e transcorrências geradas num ambiente de transpressão. $O$ autor interpreta que a componente de cisalhamento puro desenvolveu três sistemas de deformação durante o mesmo evento metamórfico, mostrando uma clara superposição cinemática. A evolução do processo de convergência, com eventos transpressivos e transtrativos associados teria culminado com a geração de uma mega estruturamem-flor positiva, em condições rúpteis-dúcteis. Como conseqüência diversos blocos tectônicos teriam sido alçados, de forma que o complexo Três Córregos e a Formação Água Clara estariam posicionados no centro da estrutura; seguidos da Formação Votuverava numa posição intermediária na aba sudeste, com suas bordas ocupadas pelas formações Capirú (a sudeste) e Itaiacoca (a noroeste).

Campanha (2002) apresentou uma interpretação mecânica na qual todas as estruturas da região teriam sido geradas em processos tectônicos associados a uma convergência obliqua entre duas placas. Nesse modelo, a trama NE-SW estaria relacionada à convergência das placas e fechamento oceânico. Após a colisão obliqua se desenvolveriam os sistemas conjugados de cisalhamento de direção ENE (e.g. Zona de Cisalhamento Ribeira) e NNE (e.g. Zona de Cisalhamento Morro Agudo). A etapa final seria representada pelos movimentos tardios controlados pelo cisalhamento paralelo à borda da placa, materializada pela Zona de Cisalhamento Lancinha. 


\section{COMPARTIMENTAÇÄO TECTÔNICA}

Visando facilitar as abordagens na área de estudos, esta foi dividida em blocos tectônicos separados por zonas de cisalhamento regionais, dos quais são citados aqueles diretamente relacionados à Zona de Cisalhamento Ribeira: blocos Barra do Turvo, Serra da Bandeira, Eldorado, Rio das Pedras e Adrianópolis.

\subsection{Bloco Barra do Turvo}

O Bloco Barra do Turvo ocorre a sul da Falha da Lancinha (Fig. 4.1). As unidades inseridas nesse bloco compreendem essencialmente rochas do Complexo Turvo-Cajati, embora ocorram subordinadamente rochas do Complexo Gnáissico-Migmatítico e da Formação Capirú (Fig. 4.2).

As rochas do Complexo Gnáissico-Migmatítico, no sentido de Vasconcelos et al. (1999), consistem de gnaisses ortoderivados com feições de assimilação e/ou mistura mecânica de boudins máficos/utramáficos pelas porções quartzo-feldspáticas, indicando deformações em regimes fortemente dúcteis de altas temperaturas. Os mesmos autores cartografaram, nas folhas Rio Guaraú e Jacupiranga, três domínios litológicos denominados de Ortognaisses Bandados, Ortognaisses Porfiroclásticos e Granitóides Foliados. Na área de estudos foram identificadas rochas semelhantes àquelas descritas no dominio dos ortognaisses bandados. Correspondem a gnaisses bandados $e$ laminados formados por plagioclásio, quartzo, hornblenda e biotita. O bandamento é dado pela alternância entre leitos cinzentos ricos em hornblenda e biotita com lâminas milimétricas, esbranquiçadas, formadas por quartzo e feldspato. A ocorrência de porfiroclastos centimétricos de feldspato estirado confere um aspecto de augen gnaisse. Bandamento com leitos muito contínuos, porfiroclastos lenticulares assimétricos, forte estiramento de leitos e veios de quartzo incorporados à foliação indicam uma natureza milonítica para esta. Lineações de estiramento de baixo mergulho e kink bands com eixos subverticais sugerem movimentos direcionais horários. Vasconcelos et al. (1999) obtiveram idades U/Pb em zircão de $2.148 \pm 37 \mathrm{Ma}$, para rochas do domínio de ortognaisses porfiroclásticos, interpretadas como idade de cristalização.

O Complexo Turvo-Cajati, ocorrente exclusivamente a sul da Falha da Lancinha, tal como definido originalmente por Silva \& Algarte (1981a, b), encontra-se em contato tectônico com o Complexo Gnáissico-Migmatítico (Vasconcelos et al., 1999). Constituí-se de uma seqüência de rochas metassedimentares que inclui micaxistos, quartzomicaxistos, cálcio xistos, mármores dolomíticos, quartzitos, rochas calciossilicáticas, 
paragnaisses, migmatitos aluminosos/calciossilicáticos e paranfibolitos. Vasconcelos et al. (1999) incluiram o que denominaram Gnaisse de Itapeúna no Complexo Turvo-Cajati devido a identificação de feições de campo indicativas de que as rochas graníticas apresentam protolitos estritamente associados às rochas metassedimentares deste complexo. No entanto, pelas nossas descriçöes de campo consideramos que essa unidade é representada por granitóides que podem ser isótropos à protomiloniticos, mas não gnáissicos. Desse modo é preferível adotar a nomenclatura de Maciço de Itapeúna.

Os micaxistos são as rochas de maior expressão do complexo. Correspondem a muscovita-biotita xistos com proporçōes variadas de quartzo. Granada, sillimanita e turmalina geralmente estão presentes em menores proporções. Vasconcelos et al. (1999) descrevem xistos contendo quartzo, biotita, muscovita, granada, sillimanita, plagioclásio e estaurolita. Também descrevem rochas que incluem em sua composição cristais de cianita e andalusita. Variações dos micaxistos para rochas gnáissicas indicam um incremento do grau metamórfico. Os gnaisses são bandados e constituidos por quartzo, plagioclásio, biotita, feldspato potássico, granada, sillimanita e clorita (Vasconcelos et al., 1999). Intercalações de rochas carbonáticas são comuns (Vasconcelos et al., 1999).

Rochas calciossilicáticas ocorrem em meio aos dominios de paragnaisses, migmatitos e micaxistos, além de enclaves no Maciço de Itapeúna. A mineralogia essencial é representada por tremolita, diopsídio, hornblenda, epidoto e quartzo. Podem incluir também feldspato potássico e biotita, como essenciais, além de clorita, sericita e carbonato como acessórios (Vasconcelos et al., 1999).

As rochas graníticas do Maciço de Itapeúna apresentam granulação média a grossa, estrutura homogênea a heterogênea e composição tonalítica a granitica. Minerais essenciais consistem de plagioclásio, feldspato potássico, quartzo e biotita. Clorita, sericita, carbonato e granada, quando presentes são acessórios. Nas proximidades da Falha da Lancinha os litotipos consistem de brechas cataclásticas, protomilonitos, milonitos e ultramilonitos. Predominam as brechas e protomilonitos. Geralmente a foliação é linear, caracterizando tectonitos tipo LS.

Finalizando, a Formação Capirú, não estudada neste trabalho, é formada por filitos e ardósias com laminaçc̃es e acamamentos primários preservados. Geralmente essas estruturas encontram-se dobradas, onde identifica-se uma clivagem ardosiana associada. Ocorrem também intercalaçōes de corpos alongados de quartzitos, além de metacherts e pequenos corpos de mármores calcíticos ou dolomíticos (Campanha, 1991). 


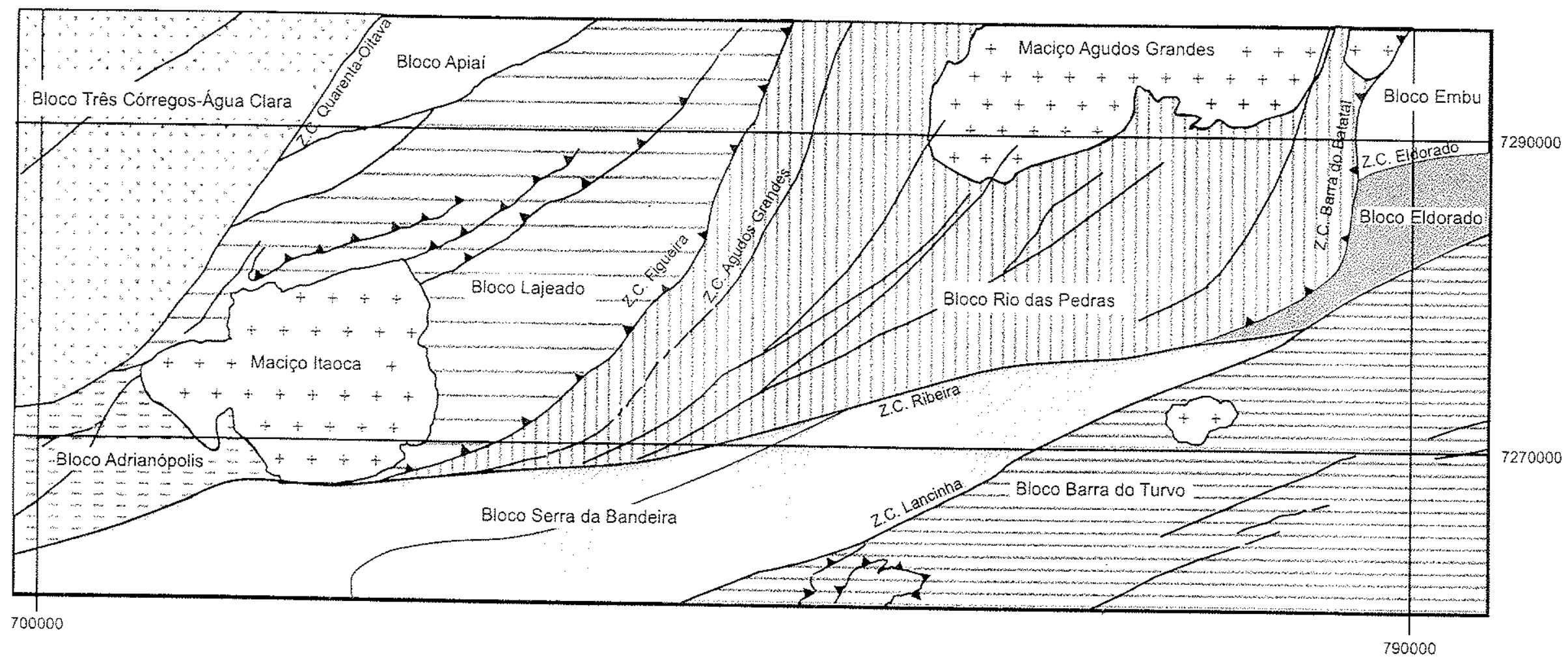

Figura 4.1. Representação da compartimentação da área de estudos em blocos tectônicos separados por zonas de cisalhamento 


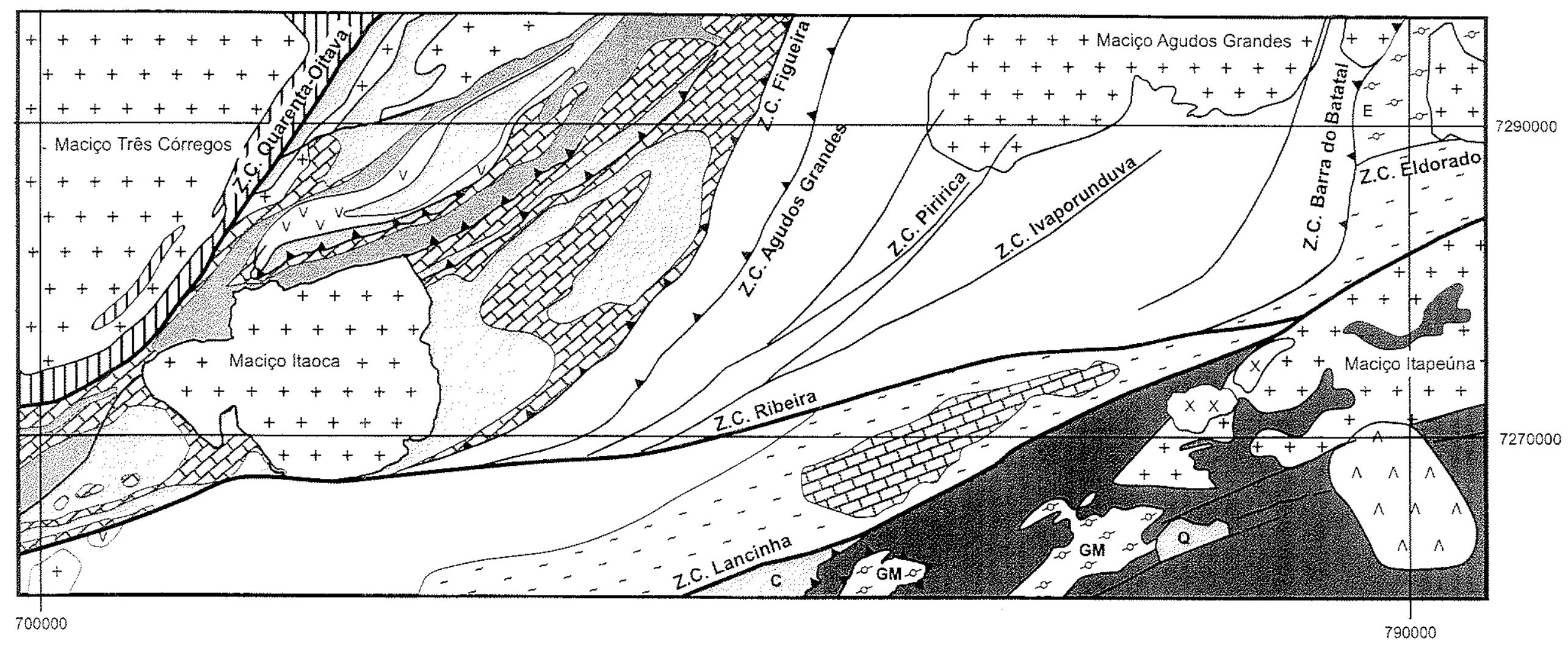

Cretáceo

$\triangle$ Maciço Alcalino de Jacupiranga Cambriano a Neoproterozóico

$x$ Rochas graniticas pós-tectônicas

Q Formação Quatis (bacia molassóide)

Neoproterozóico

+ Rochas graniticas sin-tectônicas

Gabro de Apiai
Neo a Mesoproterozóico

Subgrupo Lajeado (metarritmitos)

Subgrupo Lajeado (metarenitos)

KEY Subgrupo Lajeado (mármores)

C Formação Capiru (metarritmitos)

Subgrupo Ribeira indiviso

(metarritmitos, metarritmitos, metaconglomerados, metabasitos)

In Mármore da Tapagem

- - Seqüência Serra das Andorinhas (micaxistos finos)
Neo a Mesoproterozóico

DII Formação Ȧgua Clara (metamargas e xistos)

Seqüencia Turvo-Cajati (micaxistos)

$\sim \sim$ (E) Complexo Embu (paragnaisses)

Paleoproterozóico

F.- (GM) Complexo Gnáissico-Migmatitico (gnaisses)

Fathas transcorrentes

A. Falhas de empurrấo ou inversas

Figura 4.2. Mapa geológico simplificado 


\subsection{Bloco Serra da Bandeira}

O Bloco Serra da Bandeira limita-se pelas zonas de cisalhamento Lancinha (a sul), Ribeira (a norte) e Morro Agudo/ZCR (a oeste) (Fig. 4.1). Compreende a Seqüência Serra das Andorinhas, o Mármore da Tapagem, e parte do Subgrupo Ribeira (Fig. 4.2).

Os litotipos presentes na Seqüencia Serra das Andorinhas consistem de filitos e xistos carbonáticos, quartzo xistos, quartzitos, mármores e metabasitos. Predominam rochas com xistosidade bem desenvolvida, geralmente com laminação diferenciada onde alternam-se leitos ricos em quartzo com leitos ricos em micas. Minerais essenciais compreendem muscovita, biotita e quartzo. Granada, turmalina, magnetita e clorita podem estar presentes em pequenas quantidades. Os filitos e xistos carbonáticos são variações faciológicas transicionais que apresentam como mineralogia essencial muscovita, dolomita, calcita, quartzo, feldspato e clorita, esta última em maior quantidade em relação às rochas anteriores.

O Mármore da Tapagem assenta-se sobre a Seqüência Serra das Andorinhas formando uma sinforme, provavelmente com contatos tectônicos (Campanha, 1991). Os mármores são em geral dolomiticos, finos, brancos, isótropos e homogêneos. Raramente ocorrem bandamentos composicionais, ou clivagens tectônicas.

O Subgrupo Ribeira neste bloco foi diferenciado da Seqüência Serra das Andorinhas em termos da associação de protolitos (Campanha, 1991). Desse modo, o primeiro fol considerado uma associação metavulcano-sedimentar com contribuição básica expressiva, enquanto a segunda é tipicamente de natureza clástico-terrigena.

As rochas presentes consistem de quartzo-micaxistos finos a médios, laminados, com intercalações de quartzitos, carbonato xistos, e anfibolitos. Os micaxistos são formados principalmente por muscovita, quartzo e biotita, podendo conter granada e turmalina como acessórios. Estruturas primárias preservadas são ausentes. Intercalações quartzíticas e veios de quartzo estirados e boudinados configuram uma foliação tipicamente milonítica.

Intercalações concordantes e alongadas de carbonato xistos e quartzitos são comuns. Localmente ocorrem corpos de metaconglomerados oligomíticos.

Os metabasitos mais comuns consistem de anfibolitos verde escuros, com hornblenda predominando sobre actinolita. Além de plagioclásio que também é um mineral essencial, epidoto e clorita podem ocorrer como acessórios. Metabasitos metassomatizados são raros neste bloco em relação ao Bloco Rio das Pedras.

Metabasitos mais raros são constituidos por quartzo-plagioclásio-clorita xistos miloníticos bandados. 


\subsection{Bloco Eldorado}

O Bloco Eldorado é uma cunha tectônica limitada a oeste pela Zona de Cisalhamento Barra do Batatal, a sul pelas zonas de cisalhamento Ribeira e Lancinha, e a norte pela Zona de Cisalhamento Eldorado (Fig. 4.1). As rochas presentes foram consideradas em trabalhos anteriores como parte do Complexo Embu (e.g. Vasconcelos et al., 1999) ou Grupo Setuva (Campanha, 1991; Campanha \& Sadowski, 1999).

Os litotipos principais consistem de quartzo micaxistos finos, geralmente filonitizados, com estrutura bandada e laminada. A laminação é formada tipicamente pela segregação de leitos quartzosos com filmes micáceos submilimétricos. Intensa lineação de estiramento e abundância de vênulas de quartzo estiradas e incorporadas à foliação conferem a rocha um aspecto milonitico. Geralmente observa-se dobras intrafoliais em escala de amostra de mão. Estruturas primárias tais como acamamento sedimentar não estão preservadas.

Apesar da mica reconhecida em campo ser principalmente a muscovita, rochas muito alteradas com cores roxeadas sugerem a presença de biotita. Também são comuns cristais milimétricos de granada estirada. Vasconcelos et al. (1999) descreveram a presença de sillimanita em rochas alteradas e de cianita e estaurolita em concentrados de batéia coletados nesse domínio. No entanto, em seções delgadas não foram confirmadas a presença destes minerais.

A Zona de Cisalhamento Eldorado limita os filonitos finos (a sul), com rochas gnáissicas e xistos grossos (a norte). Na faixa de mais alta deformação da Zona de Cisalhamento Eldorado ocorrem abundantes veios de quartzo paralelos a subparalelos à foliação milonitica. Tais veios apresentam-se fortemente lineados, caracterizando tectonitos tipo L. Dobras intrafoliais e kinks são comuns. Localmente ocorrem bandas tabulares com espessuras decimétricas, constituidas por feldspato e quartzo. Estas bandas encontram-se encaixadas concordantemente na foliação, e apresentam-se milonitizadas. As lineações de estiramento apresentam atitudes contrastantes. Enquanto no afloramento $M 75$, que representa a parte mais interna da zona de cisalhamento reconhecida, as lineações apresentam baixos caimentos para WSW, em afloramentos mais afastados predominam lineações de alto ângulo (capitulo 6, Fig. 6.7 e Anexo 1).

As rochas a norte da Zona de Cisalhamento Eldorado apresentam uma estrutura dominantemente gnáissica, onde bandas escuras ricas em biotita alternam-se com leitos quartzo-feldspáticos subordinados. Cristais de granada fina também estão presentes. A granulação pode ser fina a média. As bandas ricas em biotita apresentam espessuras decimétricas a métricas $e$, além da biotita, são compostas por quartzo, feldspato e granada. As bandas quartzo-feldspáticas são tabulares, extremamente estiradas e 
apresentam espessuras centimétricas a decimétricas. Ocorrem também veios de quartzo, fortemente estirados, com espessuras centimétricas a decimétricas, incorporados à foliação. Lineações de estiramento bem desenvolvidas em todos os leitos descritos sugerem natureza milonitica para a foliação. A presença de bandas quartzo-feldspáticas injetadas e bolsões graníticos pouco deformados é indicativa de migmatização.

De acordo com as descrições acima, as rochas gnáissicas ocorrentes a norte da Zona de Cisalhamento Eldorado são semelhantes àquelas descritas classicamente no Complexo Embu de Hasui \& Sadowski (1976), enquanto as rochas a sul são de mais baixo grau metamórfico (filitos/filonitos e xistos finos), as quais consideramos pertencentes à Seqüência Serra das Andorinhas.

\subsection{Bloco Rio das Pedras}

O Bloco Rio das Pedras é limitado a sul pela ZCR, a oeste pela Falha da Figueira e a leste pela Zona de Cisalhamento Barra do Batatal (Fig. 4.1). Compreende litologias do Subgrupo Ribeira indiviso e da Formação Iporanga (Campanha \& Sadowski, 1999).

o Subgrupo Ribeira indiviso é constituído por rochas metassedimentares dominantemente finas, com estruturas sedimentares primárias bem preservadas. Podem ser classificados metamorficamente como ardósias e filitos, mas como os protolitos são facilmente reconhecidos, podemos chama-las de metarritmitos finos. É notável a ocorrência de intercalações de metabasitos. No mais estão presentes lentes e camadas subordinadas de metarenitos, metaconglomerados, metacalcários e carbonato filitos.

Os metarritmitos apresentam bandas de espessura geralmente milimétrica a centimétrica (mas que podem ser métricas), com variação composicional e/ou granulométrica. Geralmente tem-se também variação na cor das bandas, principalmente quando as rochas encontram-se alteradas. Clivagens ardosianas são comuns, freqüentemente paralelas a subparalelas ao acampamento sedimentar, tendo um desplacamento planar muito intenso associado. Quando não alteradas estas rochas são tipicamente cinza-esverdeadas. Podem ocorrer corpos métricos a decamétricos de rochas metassedimentares finas com estrutura mais maciça, refletindo, provavelmente, argilitos como protolitos. Minerais mais comuns compreendem sericita, quartzo, clorita, estilpnomelano, carbonato, turmalina, minerais opacos e biotita clástica. Sericita e quartzo em geral representam em torno de $80 \%$ da rocha. Localmente essas rochas são ricas em porfiroblastos de cloritóide. Intercalações de camadas de metacherts com espessuras ao redor de $2-4 \mathrm{~cm}$, embora de ocorrência subordinada, freqüentemente foram encontrados na maioria dos afloramentos visitados. Camadas de formações ferriferas são bastante raras, e foram atribuidas a presença de camadas de metacherts 
ferríferos. Campanha (1991) cita a presença de formaçöes ferriferas fácies carbonato, constituidas por quartzo, ankerita, caulinita e magnetita. O mesmo autor identificou formações constituidas por magnetita e hematita alternadas com bandas de metacherts com cores brancas, esverdeadas e avermelhadas.

Os metaconglomerados intercalados são oligomíticos e apresentam matriz grossa constituida por quartzo, feldspato e sericita. Os seixos consistem dominantemente de quartzo e quartzito, mas não são raros seixos de filitos. Suas formas podem ser bem arredondadas ou angulosas, neste caso caracterizando brechas sedimentares. Podem apresentar estratificações incipientes ou bem desenvolvidas. Transicionam geralmente para termos cada vez mais finos, chegando a metarenitos no topo.

Os metabasitos ocorrem por toda área do Subgrupo Ribeira como corpos alongados concordantes com a foliação. Suas espessuras variam de poucos centímetros até centenas de metros. Constituem-se de actinolita anfibolitos, feldspato-clorita xistos e feldspato-clorita-carbonato fels. Os actinolita anfibolitos são finos, apresentam cores verde claras e, geralmente, estruturas maciças, onde estão preservadas texturas igneas subofiticas, ofíticas ou intergranulares. Raramente são foliadas. São compostos essencialmente de actinolita, epidoto e clorita.

Perrota (1996) subdividiu o Subgrupo Ribeira no bloco a norte da Zona de Cisalhamento Ribeira (Bloco Rio das Pedras), definindo as unidades Nhunguara, Piririca, Ribeirão das Pedras e Rubuquara.

A unidade Nhunguara é caracterizada por clorita-sericita filitos homogêneos a laminados, com intercalações de filitos carbonosos, sericitamclorita-carbonato filitos, metamargas, e metarenitos maciços a laminados em direção ao contato com filitos (Perrota, 1996).

A unidade Piririca, limitada pelas zonas de cisalhamento Ivaporunduva e Piririca, é formada por filitos carbonosos com espessas intercalações de rochas metabásicas e metaultrabásicas geralmente hidrotermalizadas (cloritização e/ou carbonatação), além de intercalações centimétricas freqüentes de sericita-quartzo filitos (Perrota, 1996).

A unidade Ribeirão das Pedras caracteriza-se por pacotes centi-decimétricos ritmicos onde alternam-se camadas de filitos sericiticos brancos, metacherts, metassiltitos e metarenitos finos ferruginosos ou magnesianos (Perrota, 1996).

A unidade Rubuquara é caracterizada pela predominância de sericita ardósias de cores violáceas e estruturas homogêneas a bandadas, com intercalações de bancos de metarenitos microconglomeráticos (Perrota, 1996). A autora descreve na base dessa unidade a presença de metabrechas oligomíticas e polimiticas com fragmentos da formados pela própria matriz (autofagia) e outros já metamórficos na época da deposição. 
A Formação Iporanga ocorre como uma extensa faixa alongada entre as zonas de cisalhamento Figueira e Agudos Grandes (Fig. 4.2). É composta dominantemente por metassiltitos (ardósias e filitos), com intercalações de metarenitos e niveis de metaconglomerados e metabrechas.

Os metassittitos apresentam estrutura bandada com clivagem ardosiana paralela ou subparalela ao acamamento. As estruturas sedimentares dominantes são estratificações gradacionais e laminações plano-paralelas. Lâminas e bandas carbonáticas impuras também estão presentes em pequena quantidade. São compostos dominantemente por sericita e quartzo, podendo conter até $10 \%$ de clorita. Biotita e. muscovita geralmente de origem clástica podem estar presentes.

Os metarenitos intercalados são geralmente arcosianos, formados por quartzo, microclínio, plagioclásio, sericita, muscovita e biotita. Grãos policristalinos de quartzito e siltito também podem estar presentes. Por vezes essas intercalações assumem caráter rítmico. Geralmente essas intercalações passam gradacionalmente para metaconglomerados polimíticos com matriz areno-arcosiana de granulação grossa. Os seixos são milimétricos a centimétricos, compostos por quartzito, quartzo, filitos $\mathrm{e}$ fragmentos de feldspatos rosados.

Lentes de metaconglomerados e metabrechas polimíticas são as rochas mais típicas da Formação Iporanga (Campanha, 1991). Os clastos podem ser milimétricos a decimétricos e, angulosos a arredondados, dependendo da litologia. Consistem de metargilitos, metarenitos, metaconglomerados oligomíticos, anfibolitos, vulcânicas ácidas, ganisses e rochas graniticas (Campanha, 1991). Clastos de filitos apresentam-se geralmente angulosos e com uma foliação interna anterior àquela desenvolvida na matriz. Essa ocorrência por vezes indica que a área fonte continha rochas metassedimentares metamorfizadas (Campanha, 1991).

\subsection{Bloco Adrianópolis}

O Bloco Adrianópolis é aqui considerado como a porção sul de uma cunha tectônica limitada pelas zonas de cisalhamento Figueira (a leste), Ribeira (a sul) e Quarenta-Oitava (a oeste). As unidades inseridas correspondem a formações alternadamente de naturezas terrigenas e carbonáticas, pertencentes ao Subgrupo Lajeado de Campanha et al., $(1985,1986)$, além da porção sul do batólito granítico Maciço Itaoca.

$\mathrm{Na}$ região abordada, o Subgrupo Lajeado não apresenta um empithamento estratigráfico preservado, tal como visto a nordeste do Maciço de Itaoca, embora as principais unidades alternadamente de naturezas siliciclásticas e carbonáticas tenham 
sido reconhecidas (MMAJ/JICA, 1981, 1982, 1983). Na porção a sudoeste do Maciço Itaoca as rochas metassedimentares foram submetidas a metamorfismo de contato associado com a intrusão desse batólito. Esse metamorfismo é bem evidente nas rochas carbonáticas, onde foram identificadas estruturas hornfélsicas e rochas xistosas com porfiroblastos de muscovita e biotita crescidas em arranjo aleatório.

Junto a ZCR, nesse bloco, as rochas metassedimentares são também mais deformadas, conforme evidenciado pelas transposições de acamamentos primários e desenvolvimento de intensa lineação de estiramento. Os litotipos principais presentes na área são filitos finos bandados (metarritmitos), quartzitos médios foliados (metarenitos) e mármores cinza escuros acamadados, interestratificados por lâminas micáceas submilimétricas.

As rochas do Maciço Itaoca, em sua porção sul, consistem de hornblenda-biotita monzogranitos pofiriticos. A mineralogia essencial compreende feldspatos róseos, quartzo, biotita e hornblenda. O batólito trunca dobras tectônicas e falhas de empurrão presentes no Subgrupo Lajeado, mas em sua porção sul é deformado na região de influência da ZCR. Descrições detalhadas sobre o batólito podem ser encontradas em Mello (1995) e Mello \& Bittencourt (1998). 


\section{PETROGRAFIA E ESTRUTURAS DAS ROCHAS DE FALHA}

\subsection{Feições Macroscópicas}

A ZCR apresenta estruturação geral ENE, foliações subverticais e movimentação dominantemente destral. Tal movimentação é muito evidente pela inflexão sigmoidal das estruturas mostradas em mapas geológicos (Anexo 1) e fotos aéreas.

Apesar da grande expressão regional a ZCR não limita blocos com ambientes tectônicos muito distintos, tendo maior importância no zonamento metamórfico e estrutural do Supergrupo Açungui. Dessa forma, as rochas a norte apresentam metamorfismo variando de grau incipiente até a fácies xisto verde inferior (zona da clorita), enquanto as rochas a sul mostram metamorfismo entre a zona da granada e a fácies anfibolito inferior. Uma mudança estrutural acompanha o aumento do grau metamórfico. Enquanto nos blocos a norte as rochas apresentam estruturas sedimentares primárias bem preservadas (acamamento, estratificações cruzadas, laminações gradacionais - Fig. 5.1A), no bloco a sul estas estruturas são praticamente destruidas, prevalecendo uma xistosidade intensa e laminações metamórficas formadas pela segregação entre leitos micáceos e quartzosos.

No campo a ZCR caracteriza-se por uma faixa de rochas cisalhadas com espessuras entre 500 e 1000 metros, onde ocorrem filonitos (Fig. 5.1B), brechas tectônicas, protomilonitos, milonitos e ultramilonitos. Uma caracteristica importante é a existência, lado a lado, de rochas de falha com texturas contrastantes (e.g. brechas e ultramilonitos), que podem refletir diferentes estágios de movimentação da zona de cisalhamento. Litotipos com competências muito divergentes e a influência da pressão de fluidos (fraturamento hidráulico) também influenciam nos diferentes produtos relacionados com o cisalhamento.

Quanto aos litotipos afetados pela ZCR predominam filitos e xistos finos pertencentes ao Subgrupo Ribeira e à Seqüência Serra das Andorinhas, além de intercalações de rochas calciossilicáticas, quartzitos, metaconglomerados, anfibolitos e intrusões graníticas variadas,

Os filitos e xistos finos apresentam cores cinzentas e esverdeadas quando não alterados. São constituidos principalmente por sericita, quartzo e clorita. Feições de cisalhamento, apesar de muito dificil reconhecimento, são ressaltadas quando da presença de grande quantidade de veios de quartzo estirados e boudinados dentro da foliação (Fig. 5.1C), pela forte transposição de foliações primárias (Fig. 5.1B) e pela presença de foliações SC e dobras intrafoliais. Estruturas observadas com menor 
freqüência compreendem kink bands com eixos subverticais. Em um único afloramento observou-se uma dobra em bainha de dimensão centimétrica e eixo subhorizontal.

É importante destacar que fora das faixas cisalhadas a presença de veios de quartzo torna-se muito rara, indicando que estes estão intimamente relacionados com as zonas de cisalhamento.

Lineações de estiramento intensas podem ocorrer em quartzo xistos e quartzitos (Fig. 5.1D), mas em geral, nos litotipos mais micáceos (dominantes), quando existem lineações, tornamse muito dificil separar as relacionadas com estiramento daquelas de interseção entre foliações e crenulações. Nesses casos as lineações de estiramento foram identificadas em paredes de veios de quartzo e metacherts, onde geralmente são bem visiveis.

Na porção sul da área as rochas apresentam um grau metamórfico mais elevado. Ocorrem xistos grossos compostos por muscovita, quartzo, biotita e granada, com intensa lineação mineral de muscovita e biotita e uma laminação milimétrica formada pela segregação metamórfica entre leitos quartzosos e micáceos. Quando presente nessas rochas, a clorita é retrometamórfica.

As rochas calciossilicáticas são finas e caracterizadas por um bandamento milimétrico onde alternam-se leitos carbonáticos marronzados com leitos quartzosericiticos esverdeados. Apresentam feições de cisalhamento bem desenvolvidas, tais como leitos de espessuras contínuas dispostas em arranjo anastomosado, porfiroclastos sigmoidais e lineação de estiramento intensa.

Metaconglomerados próximos à ZCR na parte centroeste da área, são suportados por uma matriz arcosiana e apresentam clastos centimétricos de quartzo leitoso, silexito negro e metassiltitos. Os clastos apresentam-se fortemente estirados nos cortes $X Z$ e $Y Z$ e praticamente circulares no corte $X Y$, refletindo elipsóides oblatos tipo pizza (ver capítulo 8).

Os anfibolitos são verde escuros e ocorrem como corpos concordantes com a foliação. Apresentam larguras geralmente de dezenas a centenas de metros, apesar de localmente ocorrerem corpos de espessura decimétrica a submétrica (Fig. 5.1E). Nesse caso, apresentam-se estirados e boudinados da mesma forma que os vejos de quartzo. Apresentam em geral lineações mais desenvolvidas que foliações, caracterizando tectonitos tipo L. A litologia poderia, em parte, ser responsável por essa característica, pois os anfibólios apresentam formas prolatas. No entanto, como será visto nos capítulos 8 e 9 , as rochas desse bloco tectônico apresentam varias evidências de que predominam tramas prolatas. A cor verde escura sugere que o anfibólio presente é constituido principalmente por hornblenda. 

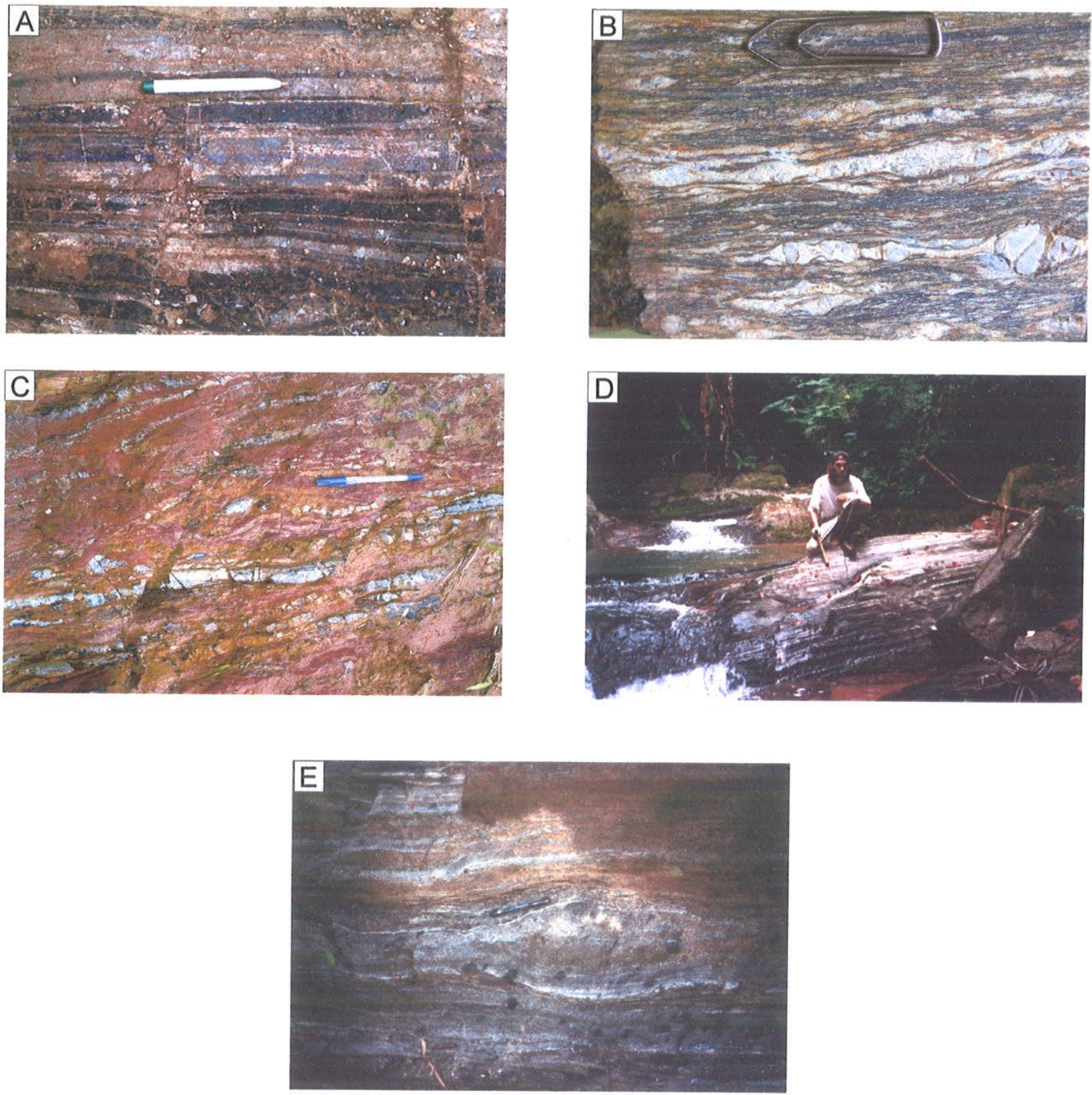

Figura 5.1. llustrações de feições observadas em campo.

(A) Acamamento sedimentar primário preservado.

(B) Filonitos com intensa foliação lenticularizada.

(C) Feições miloníticas ressaltadas pela grande quantidade de veios de quartzo incorporados à foliação.

(D) Lineação de estiramento intensa em xistos quartzosos.

(E) Anfibolitos em corpos decimétricos paralelos à foliação milonítica. 
De todas as rochas descritas, as graníticas são as que apresentam feições mesoscópicas de cisalhamento mais nítidas, tais como estrutura brechada, foliação lenticularizada, lineação de estiramento e porfiroclastos rotacionados. Predominam protomilonitos com estrutura formada por porfiroclastos de feldspato e quartzo arredondados, sendo envoltos por uma matriz fina constituida por quartzo, muscovita e biotita. Porfiroclastos rotacionados do tipo sigma mostram assimetrias dominantemente destrais.

As rochas da porção sul do Maciço de Itaoca são monzograníticas e apresentam texturas porfiriticas e estruturas foliadas. São formadas essencialmente por feldspatos, quartzo, biotita e hornblenda. Os feldspatos são róseos e suas dimensões variam de subcentimétricas a até $2 \mathrm{~cm}$. São indistinguiveis a olho nu. Esses cristais apresentam uma orientaçäo preferencial de forma bem definida, mas geralmente aparentam pequena deformação em estado sólido. Biotita e hornblenda são muito finas e seus agregados formam lentes bastante alongadas de espessuras milimétricas entre os cristais de feldspato. O quartzo ocorre como cristais anédricos, subédricos ou ribbons, principalmente nas porções mais ricas em feldspato. Apresentam dimensões em torno de 5 milimetros. Raramente encontram-se estirados concordantemente com a foliação, ou recristalizados dinamicamente. Essa situação sugere que o corpo igneo é tardideformacional em relação à ZCR.

Próximo à faixa de mais intensa deformação da ZCR os granitóides apresentam diversos xenólitos de rochas metassedimentares fortemente milonitizadas. Esses xenólitos ocorrem como corpos lenticulares ou tabulares paralelos à foliação, conferindo um aspecto semelhante ao gnáissico. São compostos por quartzitos, biotita-quartzo xistos e sericita-quartzo xistos, geralmente com intensa lineação de estiramento. Nessas localidades o monzogranito apresenta faixas decimétricas de milonitos, onde ocorreu intensa sericitização e recristalização de quartzo.

Duas importantes inferências podem ser feitas a partir das relações entre o Maciço de Itaoca e a Zona de Cisalhamento Ribeira: (1) O truncamento entre o batólito e as dobras e falhas que afetam o Subgrupo Lajeado indicam que esse corpo é póstectônico em relação a pelo menos um evento; (2) O fato de o batólito encontrar-se cisalhado em sua porção sul e na mesma região apresentar xenólitos de rochas miloníticas associadas a ZCR, indica que esta teve uma história evolutiva relativamente longa em relação aos outros eventos tectônicos e à cristalização do Maciço de Itaoca.

Afloramentos da Falha da Lancinha na área de estudos ocorrem na estrada entre as cidades de Itapeúna e Eldorado. Nesses afloramentos identificamos principalmente rochas graniticas cisalhadas pertencentes ao Maciço de Itapeúna. Essas rochas săo finas a médias, rosadas e de composição tonalítica a granítica. Predominam protomilonitos e 
brechas cataclásticas, sendo raramente encontrados milonitos e ultramilonitos. Em geral, as rochas de falha apresentam estrutura linear bem desenvolvida, caracterizando tectonitos tipo LS.

Deve-se ressaltar que nessa porção a Falha da Lancinha apresenta-se bem estreita em relação a ZCR, com espessuras da faixa cisalhada não ultrapassando $200 \mathrm{~m}$.

\subsection{Microestruturas e Mineralogia Metamórfica}

Cerca de 70 seções delgadas de rochas de falha da ZCR (além de outras zonas de cisalhamento associadas), foram descritas por intermédio de um microscópio petrográfico convencional. As condições metamórficas da deformação foram avaliadas pelo reconhecimento de paragêneses metamórficas e pela análise qualitativa de microestruturas e estilos de deformação.

A deformação imposta pelo Lineamento Ribeira foi de caráter dúctil a ruptil-dúctil, refletindo diversas etapas de atuação no tempo geológico. Os diferentes litotipos identificados (rochas metassedimentares, metabasitos, rochas calciossilicáticas e granitóides variados), são descritos detalhadamente abaixo.

\subsubsection{Rochas Metassedimentares}

As rochas metassedimentares afetadas pela ZCR estão inseridas em duas unidades principais (Subgrupo Ribeira e Seqüência Serra das Andorinhas - Fig. 4.2).

As rochas do Bloco Rio das Pedras consistem dominantemente de filitos e xistos finos, com mármores, quartzitos, metarcóseos e metabasitos intercalados. Estruturas sedimentares primárias encontram-se bem preservadas e representam a foliação principal.

Os xistos e filitos são formados essencialmente por quartzo e sericita/muscovita, que geralmente perfazem de 70 a $90 \%$ da rocha (Tabela 5.1). Clorita, carbonato e estilpnomelano geralmente são essenciais podendo individualmente representarem de 5 a $15 \%$ da rocha total. Acessórios comuns compreendem turmalina, epidoto, biotita, titanita, minerais opacos, apatita e zircão. Turmalina esverdeada-acastanhada e minerais opacos podem alcançar proporções de $8 \%$ (Tabela 5.1). Localmente ocorrem sericita turmalinitos xistosos e miloníticos. A biotita, quando presente, é essencialmente de natureza clástica.

Os xistos e filitos geralmente apresentam uma laminação definida pela alternância entre leitos ricos em quartzo e leitos ricos em micas. Localmente a laminação é formada por micas clásticas, indicando relíquias de uma laminação primária $\left(S_{0}\right)$. 
Apresentam uma foliação metamórfica $S_{1}$ constituida por uma xistosidade penetrativa, sub-paralela à laminação primária, com isorientação de sericita, quartzo, muscovita, clorita e estilpnomelano. Os minerais orientados nessa xistosidade apresentam-se dobrados e rompidos, desenhando uma crenulação $S_{2}$ obliqua que, em geral, não produz foliação penetrativa, mas localmente forma quartzo e sericita, orientados em uma xistosidade espaçada (Fig. 5.2A).

\begin{tabular}{lllllllllllllllll}
\hline Amostra & Se & Qtz & Clo & Car & Est & Bt & Ep & Tur & Tit & Opa & Gr & Ap & Pl & Mic & Zir \\
\hline EP001G & 60 & 20 & - & - & 12 & - & - & tr & - & 8 & - & - & - & - & - \\
F34D (1) & 20 & 30 & 05 & - & 5 & 40 & - & tr & - & tr & - & - & - & - & tr \\
F35A & 40 & 30 & 15 & 14 & - & - & - & 2 & tr & tr & - & - & - & - & - \\
F35B & 40 & 35 & - & 15 & - & - & 5 & tr & 3 & 2 & - & - & - & - & - \\
F47 & 40 & 50 & 10 & - & - & - & - & tr & - & tr & - & - & - & - & - \\
GD121A1 & 45 & 40 & - & - & - & - & - & 5 & - & 10 & - & - & - & - & - \\
GD121A2 & 45 & 50 & - & - & - & 1 & - & 4 & - & tr & - & - & - & - & - \\
GD121C & 22 & 40 & - & 5 & 3 & - & - & tr & - & tr & - & - & 10 & 20 & - \\
GD121E & 50 & 30 & - & - & - & 5 & - & 8 & - & 7 & - & - & - & - & - \\
GD179B & 35 & 50 & - & - & - & - & 15 & tr & - & tr & - & - & - & - & - \\
IP132A & tr & 17 & 50 & 7 & - & - & - & - & - & 3 & $t r$ & tr & 13 & - & - \\
IP530 & 35 & 20 & 25 & 15 & - & - & - & tr & - & 5 & - & - & - & - & - \\
M014 & 45 & 40 & tr & - & - & 10 & - & 1 & - & tr & 3 & - & - & - & - \\
M310 & 40 & 5 & - & - & - & tr & - & 55 & - & tr & - & - & - & - & - \\
M117 & 40 & 5 & - & - & - & tr & - & 55 & - & tr & - & - & - & - & - \\
M198 & 14 & 50 & tr & - & - & 25 & - & tr & - & 1 & 10 & - & tr & - & - \\
M214C & 25 & 40 & tr & - & - & 27 & tr & 1 & - & 1 & 5 & - & tr & - \\
\hline
\end{tabular}

Tabela 5.1. Proporções entre as fases minerais de xistos/filitos estimadas em lâminas petrogràticas.

A foliação $S_{3}$ relaciona-se com o cisalhamento, sendo caracterizada por lenticularização de foliações anteriores e recristalização parcial ou total de sericita, quartzo, estilpnomelano, clorita e, localmente, biotita. Rochas quartzosas apresentam quartzo ribbons fortemente estirados e matriz fina com textura poligonizada (Figs. 5.2B e D). Outros produtos compreendem foliação lenticularizada (Fig. 5.2D e F) e texturas pisciformes (Fig. 5.2C).

No interior da ZCR o quartzo ocorre como grãos recristalizados dinamicamente na matriz, onde formam texturas poligonizadas; como porfiroclastos estirados com extinção ondulante e subgrãos internos; e como ribbons mono e policristalinos. A sericita/muscovita apresenta-se comumente muito fina, lenticularizada e recristalizada na matriz milonitica, geralmente associada com clorita e estilpnomelano. Carbonato ocorre associado a vênulas estiradas e incorporadas à foliação milonítica.

No Bloco Serra da Bandeira é comum a presença de xistos mais grossos, laminados, com porfiroblastos de biotita e granada. A laminação é formada pela alternância entre leitos lepidoblásticos ricos em micas e leitos granoblásticos formados por quartzo poligonizado. Litotipos do Subgrupo Ribeira ocorrentes nesse bloco 
apresentam mineralogia essencial composta por quartzo, biotita, muscovita e granada. Minerais acessórios compreendem turmalina, minerais opacos, clorita, feldspato e epidoto.

O quartzo ocorre como grãos poligonais formando textura em mosaico de alto equilíbrio (contatos a $120^{\circ}$ ), dispostos em bandas muito contínuas alternadas com leitos micáceos.

Muscovita e biotita por vezes apresentam-se bastante estiradas e recristalizadas em leitos pobres em quartzo (Fig. 5.3A). O quartzo nesses leitos apresenta-se como ribbons policristalinos. Essas evidências indicam a natureza milonítica da foliação principal.

Ocorrem biotitas de quatro gerações. A mais antiga apresenta-se como finas inclusões em granada, orientadas em uma foliação externamente destruída. A biotita de segunda geração ocorre como porfiroblastos de micafish com inclusões de uma foliação retilínea discordante da externa (Fig. 5.3B), indicando que essa é pós-cinemática a um evento tectônico. As formas externas fortemente lenticularizadas são decorrentes da superposição da foliação milonítica $S_{3}$ (Fig. 5.3A). A biotita da terceira geração é mais fina, fortemente estirada e associada à muscovita nos leitos micáceos, sendo, portanto, sin-milonítica. A biotita de quarta geração ocorre em sombras de pressão em granada e a partir de substituição desta, sugerindo estar relacionada com retrometamorfismo.

A granada é porfiroblástica, perfeitamente euédrica e apresenta inclusões de uma foliação retilínea com orientação divergente da foliação externa, correlacionável com aquelas encontradas na biotita de segunda geração (Fig. 5.3C). Como só existem duas foliações preservadas e a última é correlacionável com o cisalhamento, aparentemente as foliaçöes $S_{0}$ e $S_{1}$ foram totalmente destruidas. Localmente ocorre granada fina com formas lenticularizadas, cristalizadas nos leitos ricos em quartzo, sugerindo uma geração de granada sin-milonítica.

A clorita apresenta se como finas lamelas, quase indistinguiveis ao microscópio, formadas a partir de substituição das biotitas. É, portanto, tipicamente retrometamórfica.

O epidoto, juntamente com biotita e mica branca, foi gerado a partir da decomposição de mineral não identificado. Também é retrometamórfico.

Na porção leste do Bloco Serra da Bandeira (Seqüência Serra das Andorinhas), ocorrem xistos grossos com porfiroblastos de granada, muito parecidos com aqueles pertencentes ao Subgrupo Ribeira no mesmo bloco. São rochas formadas por muscovita, quartzo, biotita, granada, clorita, turmalina e minerais opacos. Uma diferença básica observada, é a presença de planos de cisalhamento obliquos à foliação $S_{3}$, formando pares $\mathrm{SC}_{1}$ (ver capítulo 7). A amostra M14 apresenta quartzo em aglomerados formando ribbons policristalinos e monocristalinos fortemente estirados, que alternam-se com leitos 
ricos em muscovita e biotita. Tanto a muscovita quanto a biotita estão fortemente estiradas, definindo texturas pisciformes. A granada é euédrica a levemente lenticularizada e apresenta dimensões variando entre 5 e $10 \mathrm{~mm}$. Localmente identificase mica branca e fina como pseudomorfo de granada, com uma foliação rotacionada incluida, indicando a existência de antiga granada sin-cinemática. Minerais opacos estão fortemente estirados na matriz. A turmalina é esverdeada-acastanhada, tal como as demais encontradas em todas rochas metassedimentares descritas.

Os turmalinitos xistosos miloníticos são caracterizados, no campo, por camadas negras de espessuras centimétricas, com foliação lenticularizada definida pela presença de augens de aglomerados de quartzo em meio a matriz muito fina de cor escura. Ao microscópio petrográfico essa rocha compreende além de turmalina, sericita, quartzo e muscovita. Foram descritas duas lâminas, cortadas no corte $X Z$ do elipsóide de deformação, representantes de rochas com graus de recristalização dinâmica contrastantes (milonitos e ultramilonitos). Nos milonitos observa-se uma intensa foliação dada pela isorientação de sericita fina recristalizada. A turmalina disseminada junto com a sericita ou em leitos distintos é geralmente idiomórfica, com zonamento de cores (castanho na borda e esverdeado no centro) e extinção ondulante, indicando processos de deformação intracristalina. Apresenta-se dominantemente em corte perpendicular ao eixo-c. O quartzo, quando presente na matriz, encontra-se recristalizado. A diferença marcante dos ultramilonitos, é que neste caso a turmalina encontra-se recristalizada dinamicamente, por vezes com subgrãos internos e intensa extinção ondulante. Tanto nos milonitos quanto nos ultramilonitos ocorrem vênulas intensamente estiradas e incorporadas à foliação, formadas por quartzo e muscovita. Nas vênulas o quartzo encontra-se poligonizado, formando texturas em mosaico com contatos retilíneos entre os grãos à aproximadamente $120^{\circ}$, indicando um alto equilibrio contrastante com a matriz milonítica. A muscovita associada é idiomórfica e disposta em orientação aleatória. Localmente ocorrem vênulas com duas gerações de quartzo, onde a mais antiga, em núcleos, apresenta granulação fina e intensa orientação preferencial de forma, sendo superposta por grãos mais grossos e poligonizados, definindo texturas em mosaico. Essas evidências indicam que o quartzo e a sericita das vênulas foram submetidos a processos de recristalização estática (annealing).

As relações texturais entre os minerais metamórficos e as foliações estão apresentadas na tabela 5.2 . 


\begin{tabular}{|c|c|c|c|c|c|c|c|}
\hline $\begin{array}{l}\text { Estágios } \rightarrow \\
\downarrow \text { Minerais }\end{array}$ & clástico & $s_{1}$ & Pós-S 1 & $\mathrm{~S}_{2}$ & Pós-S ${ }_{2}$ & $S_{3}$ & Pós-S 3 \\
\hline & \multicolumn{7}{|c|}{ Blocos a norte Zona de Cisalhamento Ribeira } \\
\hline \multirow{5}{*}{$\begin{array}{l}\text { Quartzo } \\
\text { Muscovita } \\
\text { Clorita } \\
\text { Cloritóide } \\
\text { Biotita } \\
\text { Plagioclásio }\end{array}$} & & & & & & & \\
\hline & & & & & & & \\
\hline & & & & $-\ldots$ & $---?$ & & \\
\hline & & & & & & & \\
\hline & & - & & $-\cdots$ & & $---\cdots$ & \\
\hline Quartzo & & & s a sul Zo & a de $\mathrm{Ci}$ & hamento & Ribeira & \\
\hline Muscovita & & & & & & & \\
\hline Clorita & & & & & & & \\
\hline Biotita & & & & & & & - س- \\
\hline Granada & & & & & & & \\
\hline Plagioclásio & & & & & & & \\
\hline
\end{tabular}

Tabela 5.2. Relaçŏes texturais entre os minerais metamórficos e as foliações nas rochas metassedimentares.

\subsubsection{Metabasitos}

As rochas metabásicas consistem de anfibolitos, xistos básicos e cloritaplagioclásio-carbonato fels.

Os anfibolitos ocorrentes no Bloco Rio das Pedras, quando pouco afetados pela ZCR, apresentam-se geralmente isótropos, com estruturas igneas preservadas (blastofiticas, blastosubofiticas). Os minerais essenciais são actinolita, hornblenda e epidoto (Tabela 5.3). A hornblenda é idiomórfica, zonada, verde-acastanhada e em parte representa relíquias igneas. A actinolita ocorre como poiquiloblastos orientados aleatoriamente na matriz. O epidoto apresenta-se como agregados microcristalinos preservando formas reliquiares de plagioclásio tabular, arranjados aleatoriamente. Minerais acessórios compreendem quartzo intersticial, poiquiloblastos de minerais opacos, apatita acicular e clorita xenomórfica.

Outro litotipo, encontrado em posições mais próximas do interior da ZCR, consiste de xistos básicos compostos essencialmente por clorita, quartzo, carbonato, andesina e minerais opacos, além de apatita e sericita como acessórios (Tabela 5.3). Apresentam um bandamento correlacionável com a foliação $S_{3}$ das rochas metassedimentares, onde leitos carbonáticos alternam-se com leitos ricos em clorita e quartzo recristalizado. Internamente ao bandamento os minerais apresentam uma intensa orientação preferencial de forma. A andesina é de natureza ignea e ocorre como porfiroclastos fraturados ou cristais idiomórficos ripiformes em meio a matriz fina composta por clorita e 
quartzo. Tal feição sugere que o protolito dessas rochas era de natureza ignea básica. Os minerais opacos encontram-se fortemente estirados, lenticularizados e com formas assimétricas indicativas de deformação rotacional. A sericita ocorre como sombras de pressão em porfiroclastos e como alteração de plagioclásio.

\begin{tabular}{lcccccccccc}
\hline Amostra & Hb & Act & PI & Ep & Cl & Car & Qtz & Opa & Ap & Se \\
\hline F199B & 35 & 25 & 10 & 5 & 15 & 5 & 5 & tr & tr & - \\
GD109A & 40 & 30 & 20 & 5 & - & - & tr & 5 & tr & - \\
GD177 & 10 & 50 & 20 & 15 & 5 & - & tr & tr & tr & - \\
GD486A & 15 & 45 & tr & 20 & 2 & - & 10 & 5 & 3 & - \\
GD487 & - & - & 8 & - & 30 & 20 & 30 & 10 & 2 & tr \\
GD532 & - & - & 10 & - & 15 & 50 & 5 & 8 & - & - \\
M1611 & 30 & 40 & 20 & 5 & - & - & tr & 5 & tr & -
\end{tabular}

Tabela 5.3. Proporções entre as fases minerais de metabasitos estimadas em lâminas petrográficas.

Os clorita-plagioclásio-carbonato fels são rochas isotrópicas com estrutura ignea reliquiar parcialmente preservada, reconhecida pela presença de plagioclásio (andesinalabradorita) tabular ou ripiforme em orientação aleatória e quartzo intersticial. A matriz é muito fina e constituida por agregados microcristalinos de carbonato com clorita intersticial. Em geral a matriz representa de 50 a $65 \%$ da rocha. Vênulas de carbonato e clorita cortam todas estruturas.

No interior da zona milonítica ocorrem anfibolitos miloníticos caracterizados por augens de anfibólio envoltos por matriz fina constituida por plagioclásio e hornblenda (Fig. 5.3D), além de acessórios como epidoto, apatita e minerais opacos. Os augens de anfibólio apresentam um zonamento com actinolita no centro e hornblenda tschermackítica (dominante) nas bordas (Fig. 5.3E), indicando que a milonitização foi associada a metamorfismo progressivo. Na matriz, o plagioclásio encontra-se totalmente recristalizado dinamicamente indicando temperaturas de metamorfismo relativamente altas. O plagioclásio apresenta uma fraca orientação preferencial de forma e normalmente mostra geminação lei da albita bem formada (Fig. 5.3F). A hornblenda na matriz é acicular e encontra-se disposta em orientação paralela à foliação lenticularizada. O epidoto ocorre como microcristais idiomórficos a subidiomórficos concentrados em certos leitos na matriz, porém aparentemente não está em paragênese com a hornblenda. Clorita quando presente é retrometamórfica.

Ocorrem também anfibolitos com estrutura brechada, constituídos por anfibólio com zonamento inverso àquele apresentado pelos anfibolitos miloníticos. Nesse caso predominam hornblendas tschermakíticas no interior dos cristais e actinolitas nas bordas, indicando fases retrometamórficas associadas à zona de cisalhamento. Outra diferença importante é dada pela grande proporção de clorita (15\%), mineral praticamente ausente 
nos anfibolitos miloníticos. Os porfiroblastos de anfibólio podem estar brechados, lenticularizados ou subédricos (reliquiares). A clorita encontra-se fortemente lenticularizada e pisciforme. Quartzo e plagioclásio são finos e recristalizados na matriz. O plagioclásio apresenta extinção concêntrica sugerindo zonamentos composicionais. Epidoto microcristalino xenomórfico e carbonato ocorrem como acessórios. A estrutura é levemente orientada, onde leitos brechados ricos em anfibólio alternam-se com porções lenticularizadas formadas por clorita, plagioclásio, epidoto e quartzo. O carbonato ocorre em vênulas estiradas e incorporadas à foliação milonítica.

Somente uma amostra de anfibolito coletada no Bloco Serra da Bandeira foi descrita em seção delgada. Suas características texturais são muito semelhantes àquelas dos anfibolitos miloníticos, a não ser pela composição, onde observa-se maior porcentagem de epidoto $(15 \%)$ e a presença de clorita $(5 \%)$, sugerindo condições metamórficas levemente menos intensas. No mais, as caracteristicas de campo dos anfibolitos desse bloco sugerem que são constituídos principalmente por hornblenda, devido a cor verde escura da rocha. As estruturas e texturas observadas levam a correlacioná-las com os anfibolitos miloníticos em termos de grau metamórfico.

Rochas de ocorrência muito rara consistem de xistos grossos porfiroblásticos compostos por clorita, quartzo, feldspato, biotita, minerais opacos e granada. A clorita é porfiroblástica, pisciforme e ocupa $50 \%$ da rocha. Quartzo e feldspato são microcristalinos e recristalizados na matriz. O feldspato apresenta formas arredondadas e extinção concêntrica, sugerindo zonamentos composicionais metamórficos. Os minerais opacos encontrammse fortemente estirados. A granada é euédrica, pós-cinemática à geração de uma foliação anterior à milonitização (provavelmente $S_{2}$ ), e encontramse parcialmente substituída por biotita retrometamórfica. A clorita também pode ocorrer como sombras de pressão na granada, como resultado de retrometamorfismo. A estrutura dessa rocha consiste de um bandamento anastomosado diferenciado formado pela alternância entre lâminas lepidoblásticas ricas em clorita e leitos granoblásticos constituídos por quartzo e feldspato. Como produtos do cisalhamento, a clorita e o quartzo encontram-se fortemente estirados, lenticularizados e com extinções ondulantes ou ainda recristalizados na matriz milonítica. A grande abundância de clorita $(50 \%)$ e feldspato $(15 \%)$ sugere que esta rocha pode ser de natureza originalmente vulcanoclástica, com contribuições básicas na deposição.

$\mathrm{Na}$ tabela 5.4 são mostradas as relações texturais entre os minerais metamórficos presentes nos metabasitos e as foliações. 


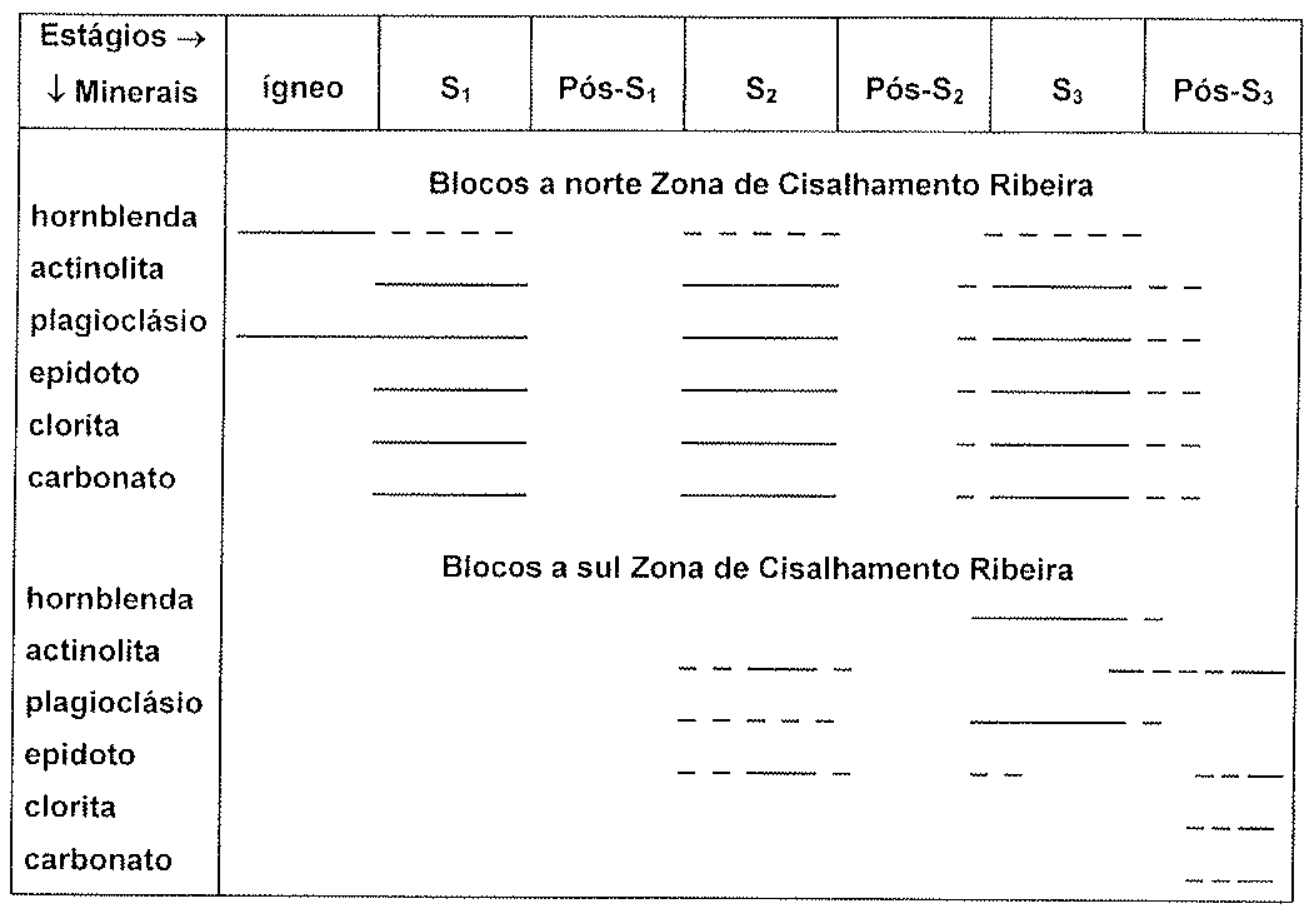

Tabela 5.4. Relações texturais entre os minerais metamórficos e as foliações nos metabasitos.

\subsubsection{Rochas calciossilicáticas}

Três tipos de rochas calciossilicáticas foram identificados: tremolititos ou actinolititos, feldspato-anfibólio-epidoto xistos bandados com granada e biotita, e quartzoclorita-feldspato-carbonato-muscovita xistos. A proporção entre cada mineral formador destes litotipos é apresentada na tabela 5.5 .

\begin{tabular}{lcccccccccccccccc}
\hline Amostra & Ep & Tre & Hb & PI & Mic & Car & Mu & Cl & Qtz & Tit & Gr & Opa & Bt & Ap & Tur \\
\hline F30C & 55 & 8 & 7 & 10 & 5 & tr & - & - & 5 & 5 & 3 & - & 1 & 1 & - \\
F33A & 15 & 65 & - & 20 & tr & - & - & - & tr & - & - & - & - & - & - \\
F33B & 3 & 65 & - & 32 & - & - & tr & - & tr & - & - & - & - & - & - \\
F48 & - & - & - & 15 & 15 & 20 & 25 & 10 & 10 & tr & - & 5 & - & - & tr \\
\hline
\end{tabular}

Tabela 5.5. Proporçōes entre as fases minerais de calciossilicáticas estimadas em lâminas petrográficas.

Os tremolititos foram identificados no extremo leste do Bloco Adrianópolis. Além de tremolita os minerais essenciais compreendem plagioclásio e epidoto. Quartzo e microclínio representam acessórios. A tremolita é idiomórfica, prismática e encontra-se isorientada formando leitos nematoblásticos. O plagioclásio é muito fino, xenomórfico e associado com a tremolita. O epidoto é fino, xenomórfico e forma agregados granoblásticos em porções localizadas. Microclínio e quartzo estão presentes em vênulas indeformadas.

Essas rochas apresentam uma lenticularização muito incipiente, que não chega a formar minerais sin-miloníticos. 
Os feldspato-anfibólio-epidoto xistos bandados, também ocorrentes na porção leste do Bloco Adrianópolis, são formados por epidoto, plagioclásio, anfibólio tremolíticoactinolítico, hornblenda, microclinio, quartzo, titanita, granada, biotita, apatita e carbonato (Tabela 5.5). Apresentam um bandamento composicional constituído por leitos nematoblásticos formados por hornblenda, feldspatos, quartzo, biotita e apatita, alternados com leitos granoblásticos ricos em epidoto, anfibólio tremolítico-actinolítico e subordinadamente plagioclásio. Os leitos ricos em epidoto são dominantes e, localmente, ricos em granada. A passagem entre um leito e outro se dá de forma gradacional. As associações fortemente contrastantes entre cada leito sugerem que o bandamento é de natureza primária. O epidoto ocorre geralmente zonado, podendo ser xenomórfico, poiquiloblástico ou idiomórfico. $O$ anfibólio tremolítico-actinolítico apresenta-se corroído e parcialmente substituido por epidoto. A hornblenda é verde muito escura, idiomórfica a subidiomórfica e associa-se a feldspatos, quartzo e biotita em bandas restritas. Feldspatos e quartzo são xenomórficos, finos e ocorrem associados. A titanita é idiomórfica e encontra-se como inclusão em epidoto e actinolita. A granada é euédrica, amarelada e pode ocorrer como inclusões em anfibólio tremolítico-actinolitico. Parece ser pré-cinemática. O carbonato ocorre como inclusões em granada, epidoto e anfibólios. As evidências texturais e composicionais sugerem que os protolitos eram constituidos por tufos básicos provavelmente metassomatizados.

Os quartzo-clorita-muscovita-carbonato-feldspato xistos ocorrem no sudoeste do Bloco Eldorado, na zona de junção da ZCR com a Falha da Lancinha. Apresentam um bandamento primário $\left(S_{0} / / S_{i}\right)$, formado pela alternância entre leitos nematoblásticos ricos em carbonato e feldspatos e leitos grano-lepidoblásticos constituídos por muscovita, clorita e quartzo. A muscovita pode ser idiomórfica (reliquiar), lenticularizada ou recristalizada na matriz, onde associa-se com quartzo e clorita muito finos e xenomórficos. Porfiroclastos lenticularizados de feldspatos (plagioclásio e microclínio), apresentam fraturas internas. Acessórios compreendem cristais idiomórficos de turmalina, titanita, zircão e minerais opacos com formas arredondadas.

As micas orientadas na xistosidade $S_{0} / / S_{1}$ encontram-se dobradas e rompidas desenhando uma crenulação $S_{2}$ fortemente obliqua, bem formada nos leitos mais micáceos. Uma lenticularização generalizada sobrepõe-se as foliações mencionadas caracterizando a foliação milonitica $S_{3}$, que gerou quartzo ribbons, lenticularização $e$ fraturamento de feldspatos e texturas pisciformes. Turmalina, titanita e minerais opacos parecem ser essencialmente clásticos. 


\subsubsection{Rochas graniticas}

As amostras de rochas graniticas cisalhadas descritas em seções delgadas pertencem às zonas de cisalhamento Ribeira e Lancinha, no caso da última, coletadas no trecho aflorante entre as cidades de Itapeúna e Eldorado. As rochas associadas com ambas as falhas mostram caracteristicas estruturais e metamórficas muito semelhantes, de forma que serão descritas em conjunto.

Essas rochas consistem de brechas cataclásticas, protomilonitos, milonitos e ultramilonitos. Os minerais essenciais são quartzo, sericita, plagioclásio e microclínio. Minerais acessórios compreendem clorita, estilpnomelano, biotita, epidoto, turmalina e zircão. Em algumas amostras o estilpnomelano, sempre associado com o cisalhamento, pode alcançar de 15 a $20 \%$ da rocha (Tabela 5.6).

Nas brechas cataclásticas os feldspatos (microclínio e plagioclásio) são angulosos e encontram-se envolvidos por uma matriz arranjada caoticamente, composta por microcristais de quartzo, sericita (Fig. 5.3G) e, por vezes estilpnomelano. Os feldspatos apresentam extinção ondulante e kinks internos, denunciando deformações intracristalinas. No entanto, predominam microfraturas e microfaihas, indicando deformações rúpteis.

Nos protomilonitos e milonitos os porfiroclastos lenticulares de feldspato encontram-se internamente fraturados, arqueados e falhados (Fig. 5.3H). Apresentam extinção ondulante intensa, subgrãos e grãos recristalizados nas bordas. A matriz recristalizada é muito fina e formada por quartzo em grãos poligonizados e sericita isorientada. O quartzo ocorre também como poríroclastos exibindo bandas e lamelas de deformação e como ribbons mono e policristalinos, geralmente com bordas poligonizadas (Fig. 5.2G). A matriz se amolda nos porfiroclastos, formando uma foliação anastomosada correlacionável com a $S_{3}$ das rochas metassedimentares.

Os ultramilonitos ocorrem raramente e são caracterizados por raros porfiroclastos lenticularizados de feldspato, formados internamente por subgrãos e grãos poligonizados, envoltos por matriz recristalizada muito fina composta por quartzo, sericita e feldspato. Forte orientação preferencial de forma desses minerais define a foliação milonítica.

\begin{tabular}{lccccccccccc}
\hline Amostra & Qtz & P1 & Mic & Se & Clo & Est & Bt & Ep & Tur & Zir \\
\hline EP001B & 55 & 10 & 10 & 15 & 7 & - & - & - & 2 & tr \\
EP001E & 50 & 5 & 5 & 37 & - & 3 & - & - & tr & tr \\
EP001F & 15 & 20 & 20 & 30 & - & 15 & - & - & - & tr \\
F46A & 30 & 20 & 10 & 15 & - & 20 & 5 & tr & - & tr \\
F94 & 25 & 35 & 20 & 20 & - & - & - & - & - & tr
\end{tabular}

Tabela 5.6. Proporções entre as fases minerais de granitóides estimadas em lâminas petrográficas. 

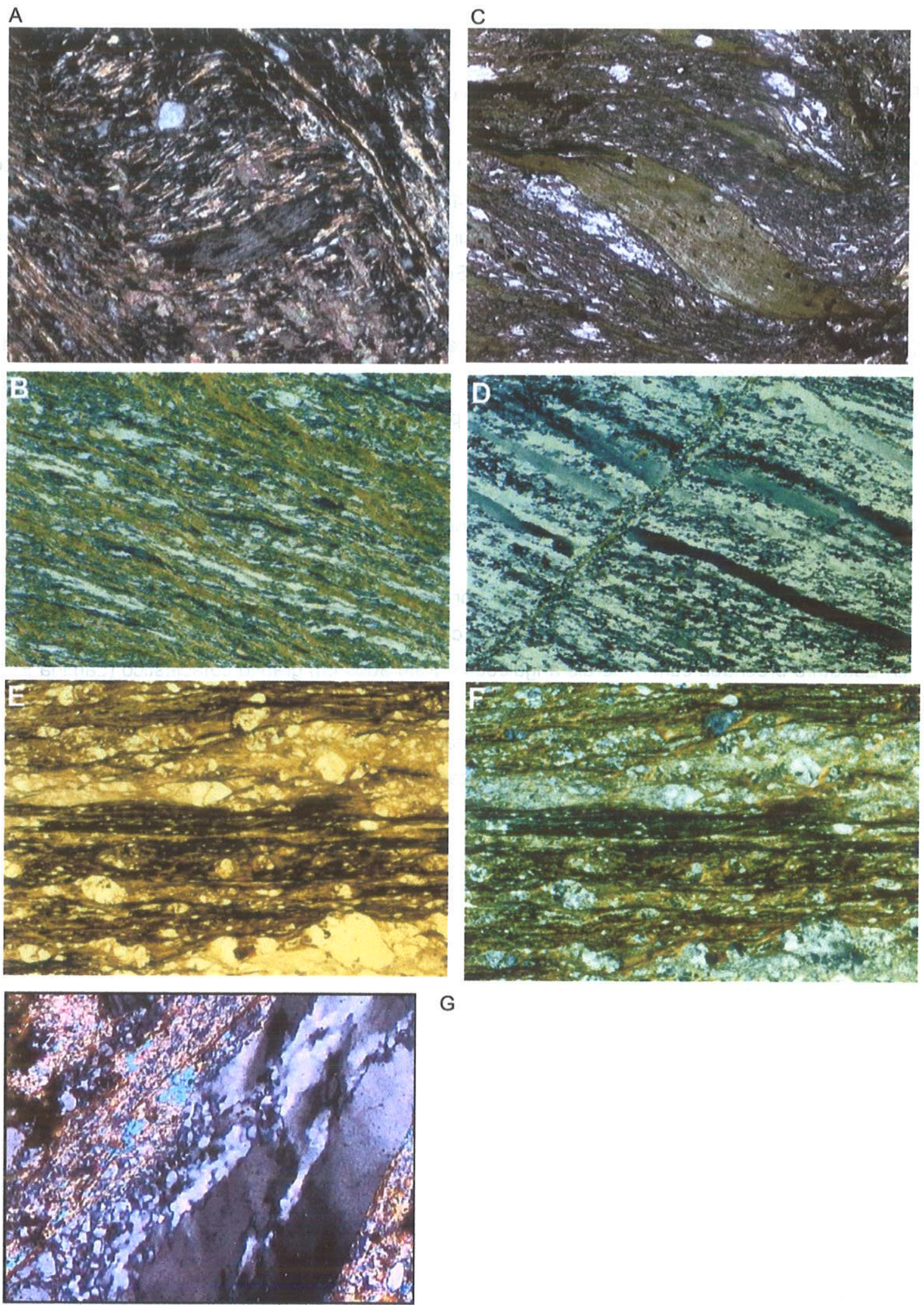

G 

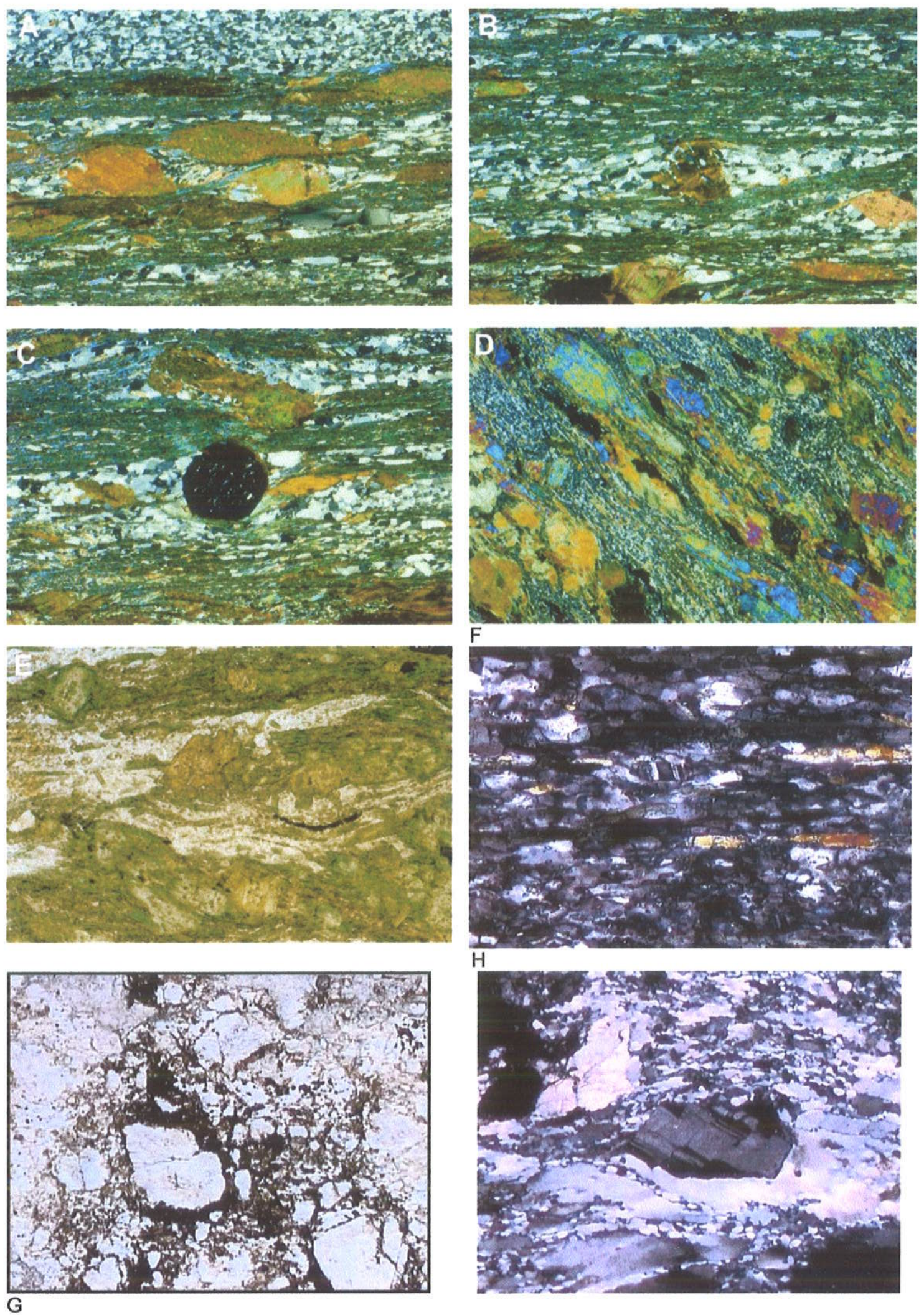


\subsection{Discussão}

\subsubsection{Metamorfismo progressivo}

De acordo com as paragêneses minerais as foliações pré-cisalhamento $\left(S_{1}\right.$ e $\left.S_{2}\right)$, nos filitos e xistos do Bloco Rio das Pedras, foram geradas em condições de fácies xisto verde, geralmente na zona da clorita. Apesar da ausência de paragêneses conclusivas, visto que sericita e clorita podem ocorrer em metamorfismo mais intenso, a abundância de estruturas sedimentares primárias bem preservadas e a ocorrência local de cloritóide (identificados somente em campo), confirmam o metamorfismo na fácies xisto verde inferior. O primeiro aparecimento da biotita em metapelitos geralmente ocorre em temperaturas ao redor de $400^{\circ} \mathrm{C}$, podendo se dar através da reação (Bucher \& Frey, 1994):

3 clorita +8 feldspato potássico $=5$ annita +3 muscovita +9 quartzo $+4 \mathrm{H}_{2} \mathrm{O}$

Devido a ausência generalizada de biotita metamórfica nas rochas do Bloco Rio das Pedras, essa temperatura é um provável limite máximo do metamorfismo a que foram submetidas. De acordo com Bucher \& Frey (1994) o cloritóide pode ser o primeiro mineral metamórfico formado em "metapelitos normais" em temperaturas próximas a $300^{\circ} \mathrm{C}$. Dessa maneira, as rochas metassedimentares dos blocos a norte da ZCR provavelmente foram metamorfizadas em temperaturas entre 300 e $400^{\circ} \mathrm{C}$ (Fig. $5.4 \mathrm{~A}$ ).

Os metabasitos do Bloco Rio das Pedras apresentam texturas blastosubofiticas bem preservadas, sugerindo que seus protolitos eram basaltos. A assembléia identificada consiste de actinolita, epidoto, clorita, albita \pm quartzo \pm carbonato \pm hornblenda ignea reliquiar. De acordo com Bucher \& Frey (1994) a assembléia diagnostica do início da fácies xisto verde é dada pelo primeiro aparecimento de actinolita e epidoto na presença de clorita e, pode ser formada em temperaturas ao redor de $280^{\circ} \pm 30^{\circ} \mathrm{C}$ em pressones menores que 6kbar, pelas reações (Fig. 5.4B):

5 prehnita + clorita +2 quartzo $=4$ zoisita + tremolita $+6 \mathrm{H}_{2} \mathrm{O}$

25 pumpellita +2 clorita +29 quartzo $=7$ tremolita +43 zoisita $+67 \mathrm{H}_{2} \mathrm{O}$

No caso analisado, não é rara a ocorrência de finas bordas de hornblenda na actinolita, sugerindo condições um pouco mais intensas de metamorfismo, porém, como o plagioclásio possui proporções de anortita < 17, essas rochas não alcançaram a fácies anfibolito. Liou et al. (1974) determinaram que a partir de $475^{\circ} \mathrm{C}$ começa a instabilidade da clorita, que tende a reduzir seu volume na rocha. Levando-se em conta que os metabasitos no bloco a norte da ZCR apresentam clorita estável, o metamorfismo não 
deve ter alcançado essa temperatura. Considerando as condições metamórficas apresentadas pelas rochas metassedimentares relacionadas, as paragêneses dos metabasitos são coerentes com metamorfismo em temperaturas entre 300 e $400^{\circ} \mathrm{C}$.

Nas rochas metassedimentares a sul da ZCR (Bloco Serra da Bandeira), as foliações $S_{0}$ e $S_{1}$ foram totalmente destruídas e a foliação $S_{2}$ é preservada como relíquias inclusas em granada e biotita pós- $S_{2}$. Essa textura indica que o pico térmico foi atingido após a geração da foliação $S_{2}$ e que houve um intervalo entre o início do desenvolvimento da foliação milonítica $S_{3}$. A paragênese quartzo + muscovita + biotita + granada e a ausência de clorita sugere que a produção de biotita e granada se deu pela reação:

1 muscovita +3 clorita +3 quartzo $=4$ almandina +1 annita $+12 \mathrm{H}_{2} \mathrm{O}$ (Fig. 5.4A)

Segundo Bucher \& Frey (1994) essa reação limita a presença de clorita em rochas contendo excesso de muscovita e deve ocorrer entre 500 e $520^{\circ} \mathrm{C}$. Como a assembléia biotita + granada permanece estável em metamorfismo de grau mais alto, esse é um limite minimo para o metamorfismo a que estas rochas foram submetidas.

Nas cercanias da ZCR as rochas de ambos os blocos Rio da Pedras e Serra da Bandeira foram cisalhadas de diferentes modos. No Bloco Rio das Pedras a foliação milonítica $S_{3}$ apresenta geralmente recristalização de quartzo, sericita, clorita $e$ estilpnomelano. Nas rochas do Bloco Serra da Bandeira foram recristalizados dinamicamente cristais de quartzo, muscovita, biotita e granada. Portanto, as paragêneses da foliação milonítica $S_{3}$ são idênticas àquelas apresentadas pelas foliações anteriores, em cada bloco, indicando que a ZCR foi responsável pelo zonamento metamórfico apresentado.

As relaçōes texturais apresentadas pelos anfibolitos miloniticos onde ocorre a paragênese tshermackita + andesina $\left(\mathrm{An}_{35-45}\right)$ indicam que o metamorfismo no interior da ZCR alcançou a fácies anfibolito. A presença de hornblenda e plagioclásio no início da fácies anfibolito ocorre primeiramente em temperaturas ao redor de $500^{\circ} \mathrm{C}$ e pressões de $5 \mathrm{Kbar}$, quando o metamorfismo segue a geoterma da cianita (Bucher \& Frey, 1994). A mesma reação continua que produz a mineralogia inicial da fácies anfibolito, continua consumindo clorita e epidoto na fácies anfibolito inferior. Eventualmente a clorita desaparece em aproximadamente $550^{\circ} \mathrm{C}$ e o epidoto não é tipicamente encontrado em anfibolitos metamorfizados ao redor de $600^{\circ} \mathrm{C}$ (Fig. 5.4B). Em pressões mais baixas o epidoto é todo consumido antes da clorita, enquanto em pressões mais altas ocorre o inverso. Condições de desaparecimento da clorita em rochas com composição basáltica foram determinadas experimentalmente em $550^{\circ} \mathrm{C} / 2 \mathrm{kbar}$ e $575^{\circ} \mathrm{C} / 5 \mathrm{kbar}$ (Liou et al,, 1974) e $525^{\circ} \mathrm{C} / 5 \mathrm{Kbar}$ (Apted \& Liou, 1983). Como os anfibolitos miloniticos apresentam 
pequenas quantidades de epidoto e clorita progressiva é ausente, a milonitização destas rochas deve ter ocorrido entre 550 e $600^{\circ} \mathrm{C}$. Esse intervalo de temperatura coincide com as condições de recristalização dinâmica do plagioclásio, que corrobora com semelhante interpretação.

As deformações nos granitóides afetados tanto pela ZCR como pela Zona de Cisalhamento Lancinha ocorreram em condições de fácies xisto verde a anfibolito inferior. De acordo com Voll (1976) os primeiros grãos de quartzo recristalizam-se em aproximadamente $300^{\circ} \mathrm{C}$. Com a progressão do metamorfismo o volume de grãos recristalizados deve aumentar constantemente. Como a porcentagem de quartzo recristalizado geralmente é grande, temperaturas maiores são sugeridas.

A presença local de feldspatos (potássico e plagioclásio) parcialmente recristalizados evidencia temperaturas em torno de $500^{\circ} \mathrm{C}$ na milonitização, visto que o inicio da recristalização destes minerais ocorre entre 480 a $520^{\circ} \mathrm{C}$ (Voll, 1980). Entretanto, a presença de ultramilonitos associados à Zona de Cisalhamento Lancinha, onde ocorrem feldspatos quase totalmente recristalizados sugerem temperaturas de deformação relativamente mais altas.

A presença de estilpnomelano em brechas e protomilonitos graniticos indica que o metamorfismo se deu em condições de fácies xisto verde (Bucher \& Frey, 1994). Dados experimentais de Nitsch (1970) sugerem que a reação de consumo do estilpnomelano:

$$
\text { estilpnomelano }+ \text { fengita }=\text { biotita }+ \text { clorita }+ \text { quartzo }+\mathrm{H}_{2} \mathrm{O}
$$

está em equilíbrio em $4 \mathrm{kbar} / 445^{\circ} \mathrm{C}$ e $7 \mathrm{kbar} / 460^{\circ} \mathrm{C}$.

Rochas de falha ocorrentes na Mina de Sete Barras mostram pelo menos duas fases de deformação, uma dúctil anterior com temperatura estimada em torno de $500^{\circ} \mathrm{C}$ (inicio da recristalização de feldspato) e uma rúptil-dúctil tardia com temperatura em torno de $300^{\circ} \mathrm{C}$ (recristalização de quartzo e sericita). A primeira deformação é preservada em fragmentos de milonitos contendo porfiroclastos de feldspato fortemente estirado $e$ quartzo ribbons em meio a matriz recristalizada com quartzo e sericita. A segunda deformação é caracterizada por brechas com cimentação fluorítica.

Nenhuma paragênese em todos os litotipos estudados é conclusiva em termos da pressão do metamorfismo. 

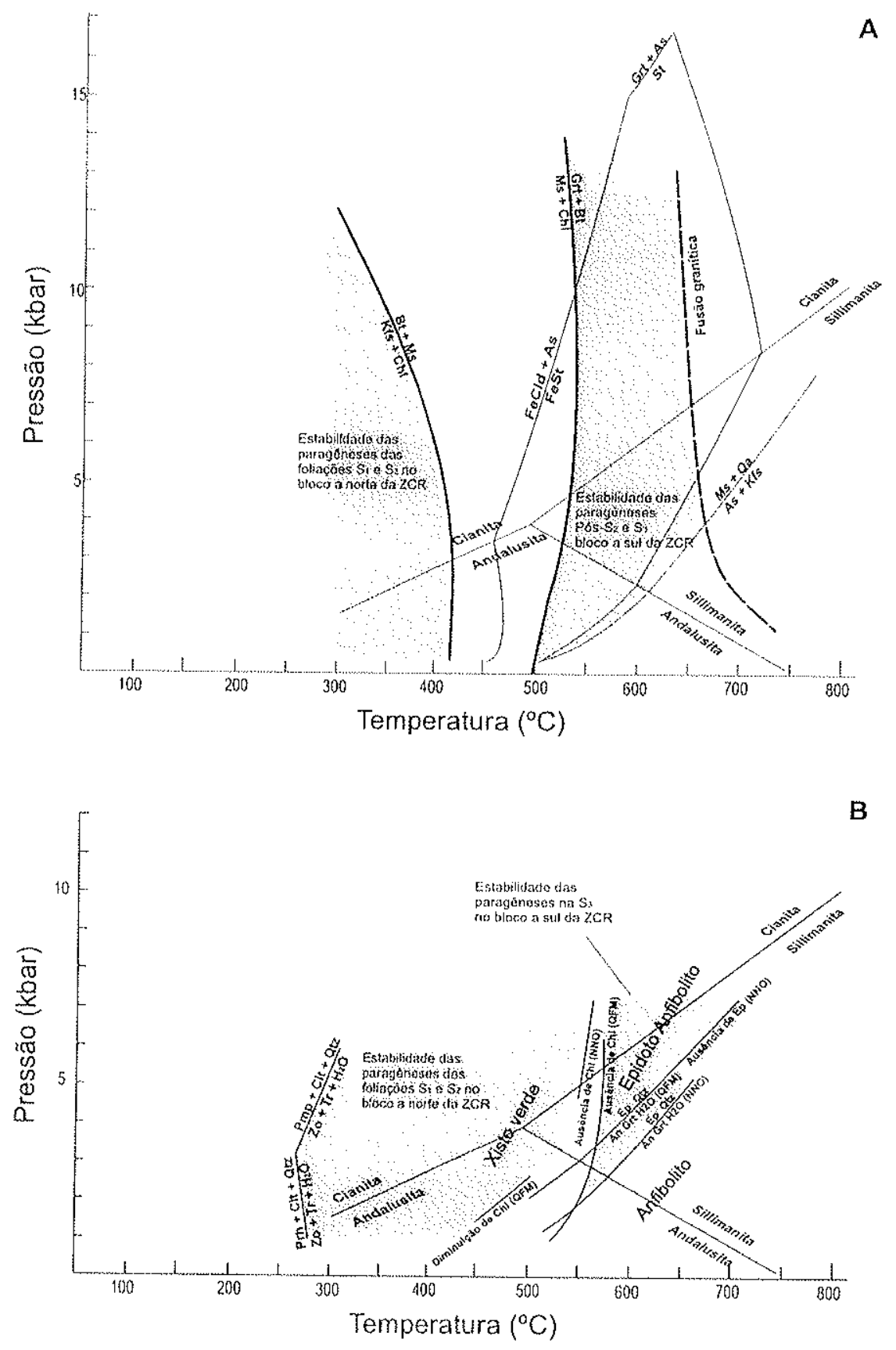

Figura 5.4. Diagrama PT com os campos de estabilidade prováveis para as paragêneses relacionadas com cada foliação metamórfica. A) rochas metassedimentares; B) metabasitos. 


\subsubsection{Metamorfismo Retrógrado}

O metamorfismo retrógrado não é muito evidente nas rochas metassedimentares do Bloco Rio das Pedras, visto que o metamorfismo progressivo é de muito baixo grau.

Nas rochas metassedimentares do Bloco Serra da Bandeira observa-se uma gradação retrometamórfica iniciando com biotita gerada em sombras de pressão em porfiroblastos de granada, seguida pela associação entre biotita, mica branca e epidoto gerada a partir de substituição granada e, culminando com a formação de finas lamelas de clorita por substituição das biotitas de todas as gerações.

Nos anfibolitos do Bloco Serra da Bandeira o retrometamorfismo é representado pela substituição de hormblenda tschermackítica por actinolita e pelas formações de clorita e epidoto.

Nenhuma das transformações é conclusiva quanto às temperaturas e pressões retrometamórficas. 


\section{ANÁLISE GEOMÉTRICA}

\subsection{Classificação dos Principais Lineamentos Regionais}

Baseado em critérios de superposição de estruturas as zonas de cisalhamento foram classificadas e hierarquizadas em quatro grupos principais (Fig. 6.1).

O grupo I consiste de falhas de alto ângulo com direção aproximada $N 35^{\circ} \mathrm{E}$ ocorrentes principalmente a norte da ZCR. São estruturas relativamente mais antigas, uma vez que são defletidas pelas zonas de cisalhamento dos outros grupos. Geraimente apresentam lineações de estiramento de caimentos altos. Como exemplos principais podemos citar as zonas de cisalhamento Figueira, Agudos Grandes e Barra do Batatal.

O grupo II compreende falhas direcionais com direção aproximada $N 80^{\circ} \mathrm{E}$, tal como a Zona de Cisalhamento Ribeira. Essas estruturas foram interpretadas como fraturas sintéticas de Riedel associadas à movimentação destral da falha tida como a principal do sistema (Zona de Cisalhamento Lancinha) (Sadowski, 1983, 1984; Fassbinder et al., 1985, 1994; Fassbinder, 1990; Sadowski, 1991). A interação entre as estruturas dos grupos 1 e Il forma, nos blocos a norte da ZCR, um padrão regional semelhante a foliações SC.

O grupo III é formado por falhas direcionais com direção aproximada $\mathrm{N} 10^{\circ} \mathrm{E}$, tal como a Zona de Cisalhamento Morro Agudo. Essas falhas infletem aquelas do grupo II de ENE para NNE, sugerindo uma movimentação sinistral.

O grupo IV é representado pelas falhas principais do sistema, que apresentam direção geral $\mathrm{N} 60^{\circ} \mathrm{E}$ e ocorrem a sul da Zona de Cisalhamento Lancinha. São exemplos as zonas de cisalhamento Lancinha, Braço Grande e Faxinal. Essas estruturas cortam todas as anteriores. A Zona de Cisalhamento Lancinha, de movimentação destral, é interpretada como a principal do sistema por vários autores da literatura. A sul da referida estrutura o padrão estrutural é bem diverso, onde passam a ocorrer foliações predominantemente de baixo mergulho e zonas de cisalhamento transcorrente sinistrais com as do Braço Grande e Faxinal (Vasconcelos et al., 1999; Campanha, 2001). Essa situação sugere uma evolução estrutural distinta entre os blocos balizados pela Zona de Cisalhamento Lancinha. 


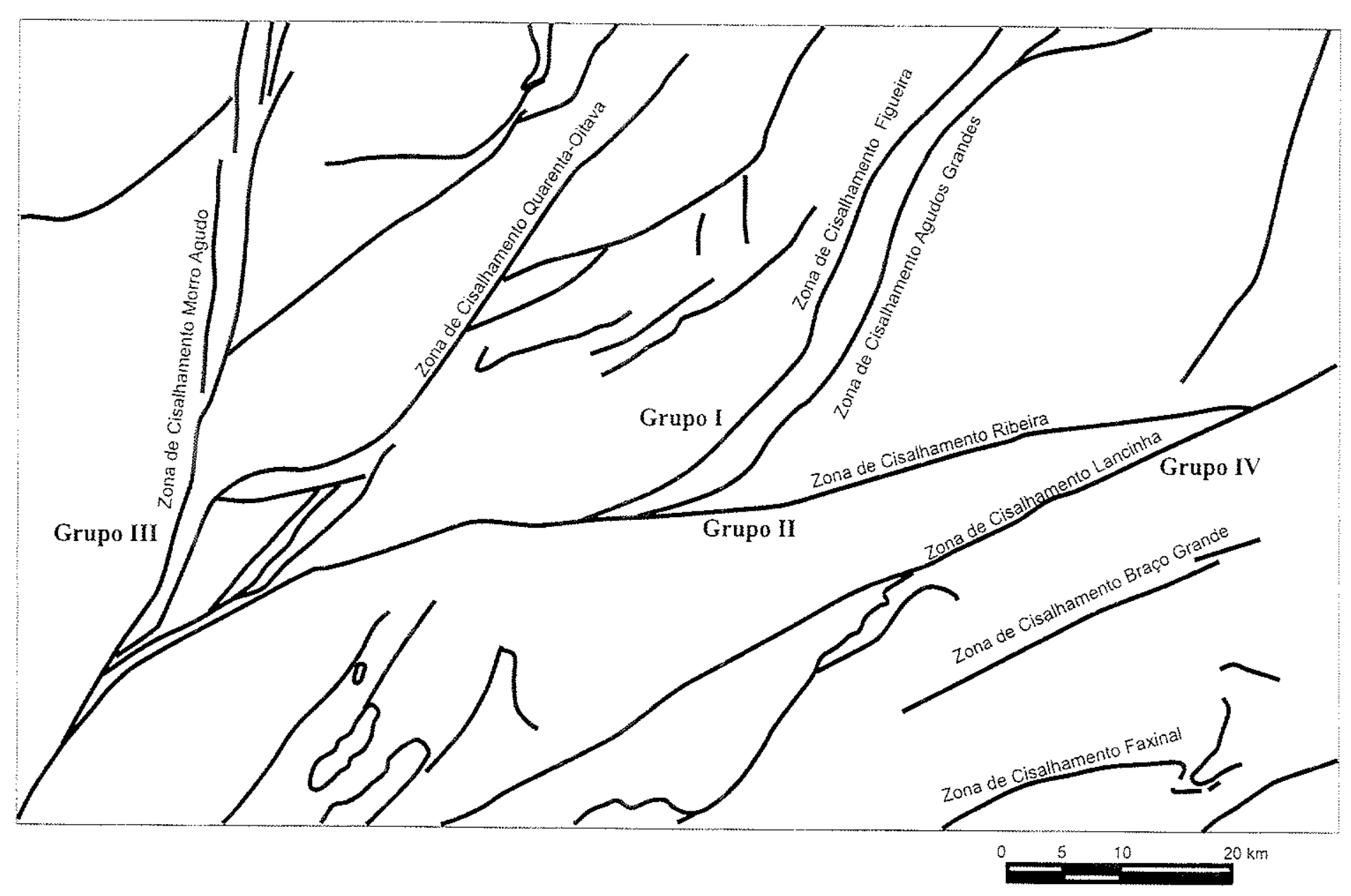

Figura 6.1. Classificação dos principais lineamentos da região estudada 


\subsection{Padrão de Isógonas}

O método de isógonas (linhas que unem pontos com mesma orientação da foliação das rochas), inicialmente desenvolvido para a análise de forma de dobras em perfil (Ramsay, 1967), foi proposto também para análise de zonas de cisalhamento (Ramsay, 1980; Ramsay \& Huber, 1983) e de padrões gerais de estruturas dobradas em mapa (Elliott, 1968).

Com o emprego desse método é possivel avaliar se a geração de uma zona de cisalhamento é coerente com o mecanismo de cisalhamento simples heterogêneo (Ramsay \& Graham, 1970).

Em uma zona de cisalhamento gerada por cisalhamento simples heterogêneo, as isógonas deveriam ser paralelas às paredes da zona de cisalhamento. A foliação se iniciaria a um ângulo de $45^{\circ} \mathrm{com}$ essa estrutura, nas porções externas menos deformadas, tendendo a zero grau na porção central da zona de cisalhamento. No entanto, nunca sendo, em teoria, totalmente paralela.

Nas zonas transpressivas o ângulo inicial das foliações com a zona de cisalhamento seria menor que $45^{\circ}$ e nas zonas transtrativas maior que $45^{\circ}$. Nas zonas de cisalhamento afetando foliações e estruturas anteriores, os padrões são mais complexos.

Campanha et al. (1993), Campanha \& Sadowski (2002) e Fiori (1985a, 1997) aplicaram o modelo de cisalhamento simples, pela interpretação das isógonas em trechos das zonas de cisalhamento Ribeira e Lancinha. No entanto, os primeiros autores analisaram somente uma porção restrita da ZCR e o segundo estudou sua parte oeste, onde esta une-se com a Zona de Cisalhamento Morro Agudo. No presente trabalho foram traçadas as isógonas de uma área que abrange todo trecho da ZCR, além de grande parte das falhas Morro Agudo, Lancinha, Figueira, Agudos Grandes, Quarenta-Oitava e Carumbé, entre outras. Assim, obteve-se uma visão mais ampla das relações entre essas zonas de cisalhamento.

Inicialmente foram traçadas as tendências médias de orientação das estruturas em mapa, tomando-se como base a xistosidade paralela ao acamamento nas unidades de maior intensidade da deformação (blocos Serra da Bandeira, Rio das Pedras e Eldorado) e também a partir da superfície axial de macrodobras mapeadas nas unidades menos transpostas (e.g. Bloco Lajeado). A partir desse traçado elaboramos um mapa de isógonas tomando-se como referência de isógona $0^{\circ}$ a orientação média da ZCR (Figs. 6.2 e 6.3). 


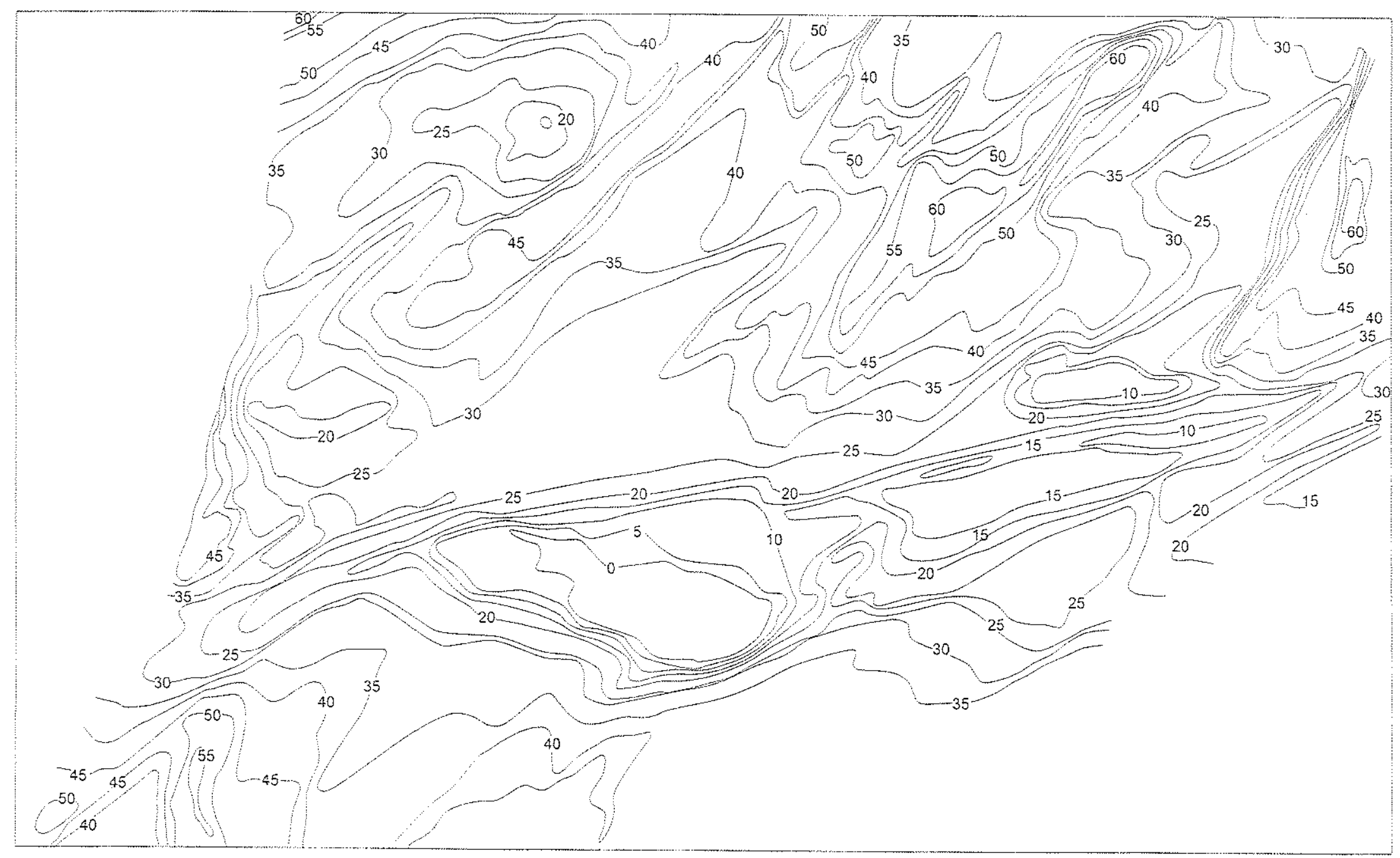

Figura 6.2. Distribuição das isógonas obtidas para as estruturas presentes no Vale do Ribeira, tendo como refefência a zona de cisalhamento homônima 


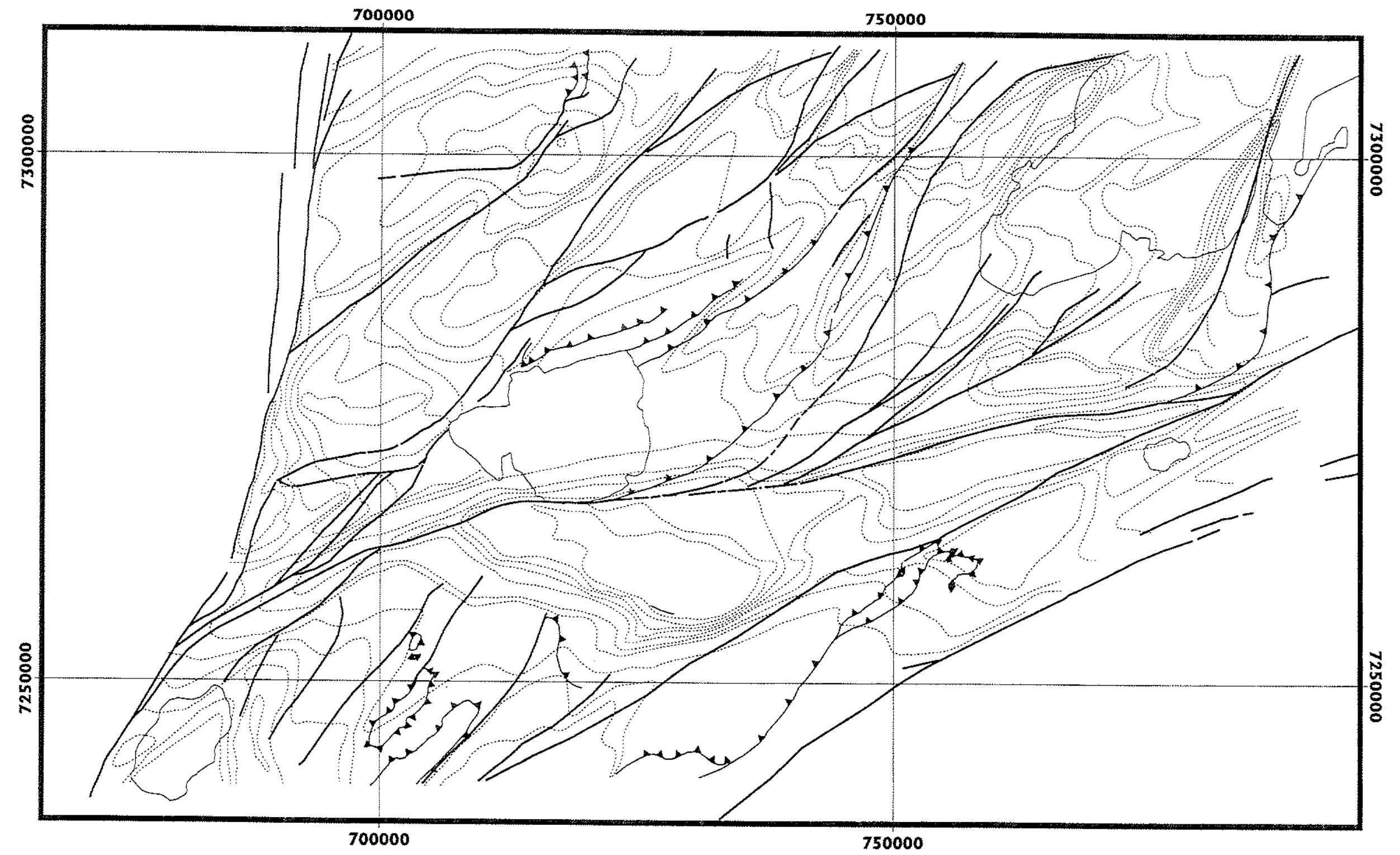

Figura 6.3. Mapa de isógonas com a representação das principais zonas de cisalhamento regionais 


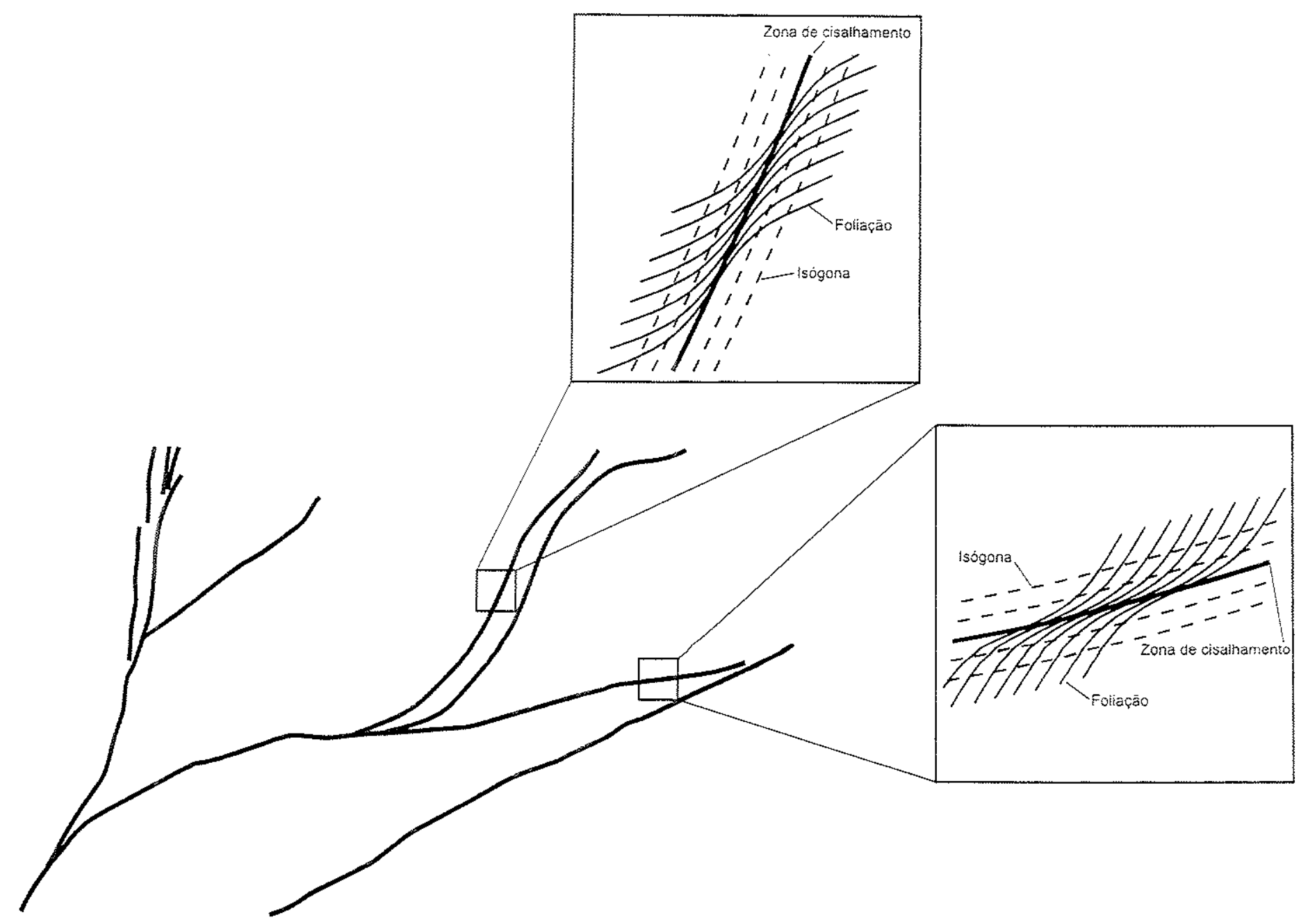

Figura 6.4. Interpretação do padrão de interferência entre as estruturas dos grupos I e ll, responsável pela padrāo de isógonas.

$\pm$ 


\subsubsection{Descrição do padrão de isógonas}

O padrão do traçado de isógonas tomando se como base a ZCR (Figs. 6.2 e 6.3), pode ser separado em dois dominios principais limitados pela mesma (domínios norte e sul).

No domínio sul as isógonas dispõem-se em orientação geral ENE, mantendo certo paralelismo com as zonas de cisalhamento Ribeira e Lancinha. No entanto, grandes anomalias em relação ao padrão esperado são encontradas, tais como uma região onde as estruturas apresentam-se orientadas na direção NW. Essa situação é resultado da inflexão NW das estruturas na borda da Megantiforma da Serra do Cadeado, feição esta ainda não suficientemente explicada na literatura. Na porção oeste do domínio sul as isógonas apresentam uma tendência de orientação NNE na zona de influência da Falha de Morro Agudo.

No domínio norte ocorre um paralelismo entre a ZCR e as isógonas de valores entre $0^{\circ}$ e $25^{\circ}$. A isógona de $25^{\circ}$ apresenta-se paralela em grande trecho, mas a leste é defletida para NE na zona de influência de uma falha subsidiária. As isógonas de valores maiores que $25^{\circ}$ dispõem-se em orientação principal NE. Esse padrão mostra uma nítida interferência entre duas familias principais de falhas (com direções ENE e NE, grupos II e I, respectivamente).

\subsubsection{Discussão}

No domínio norte ocorre uma nitida interferência entre estruturas de direção NE (dominantes), sendo infletidas por estruturas ENE subsidiárias (Figs. 6.2 e 6.3).

Em ambos os domínios norte e sul, ocorrem máximos com isógonas de $60^{\circ} \mathrm{em}$ relação à ZCR. Como o ângulo máximo que uma foliação gerada concomitantemente com uma zona de cisalhamento dúctil por cisalhamento simples heterogêneo é de $45^{\circ}$, duas hipóteses podem ser inicialmente levantadas: 1) as estruturas NE seriam foliações pré-existentes e teriam sido rotacionadas na época do desenvolvimento das falhas de direção ENE; 2) As estruturas NE e ENE teriam sido geradas concomitantemente num processo de transtração.

A hipótese de transtração pode ser descartada visto que as falhas de direção NE apresentam em sua maioria foliações subverticais e lineações de alto ângulo (e.g. falhas da Figueira e Agudos Grandes), sendo dessa forma incompativeis com a geometria de falhas transtrativas (foliações e lineações de baixo ângulo). No caso de transpressão a foliação deve ser ainda menor que $45^{\circ}$ e, portanto, um único processo transpressivo (e.g. 
no sentido de Sanderson \& Marchini, 1984), não é adequado para explicar a geração das foliações na área de estudos.

Nesse caso a primeira hipótese torna-se até o momento mais provável.

Mesmo admitindo-se que as estruturas $\mathrm{NE}$ (grupo l) pré-datam a formação das estruturas ENE (grupo II), os padrões de isógonas obtidos mostram que estas falhas não se comportaram como estruturas passivas no momento da superposição das falhas do grupo II, mas que foram reativadas com componentes direcionais (Fig. 6.4). Uma possibilidade de explicação é que as falhas do grupo I inicialmente foram geradas como falhas inversas e com a progressão da deformação reativadas como falhas obliquas à direcionais.

\subsection{Orientação das Foliações e Lineações}

\subsubsection{Zona de Cisalhamento Ribeira}

As foliações miloniticas $\left(S_{3}\right)$ associadas à ZCR não apresentam grandes variações de atitude. A grosso modo, essas variações estão relacionadas com a inflexão regional da zona de cisalhamento. Foram reconhecidos quatro dominios principais denominados pelos números $1,2,3$ e 4 (Fig. 6.5). No tocante às lineações de estiramento ocorre um padrão mais complexo.

Quanto às foliações, observa-se que domínios com tendência E-W alternam-se com dominios com tendência NE-SW. Desse modo, os dominios 1 e 3 são muito semelhantes, e apresentam foliações médias com mergulhos de $85^{\circ}$ para o azimute $345^{\circ}$ e de $85^{\circ}$ para o azimute $346^{\circ}$, respectivamente (Fig. 6.5). Os domínios 2 e 4 , onde as foliações tendem à direção NE, apresentam foliações médias com mergulhos de $80^{\circ}$ para o azimute $337^{\circ}$ e de $89^{\circ}$ para $153^{\circ}$, respectivamente (Fig. 6.5). Com exceção do domínio 4 , as foliações mergulham dominantemente para noroeste.

As lineações de estiramento apresentam geralmente caimentos baixos para ENE ou WSW, mas não são raras lineações com caimentos moderados a altos. Como pode ser observado na figura 6.5 as lineações de alto ângulo concentram-se no domínio 3 , justamente na faixa de interação entre as zonas de cisalhamento Ribeira, Figueira e Agudos Grandes. Nos domínios 1 e 2 foram obtidas atitudes médias de $256^{\circ} / 07^{\circ}$ e $053 \% 19$, respectivamente (Fig. 6.5). Apesar das lineações de estiramento do domínio 4 apresentarem atitude média de $054 \% 2$, no campo observam-se mergulhos em torno de $30^{\circ}$ ora para NE ora para SW (ver mapa geológico, Anexo 1). 
No dominio 3 pode ser separado um subdominio representado pelas rochas milonitizadas na borda sul do Granito Itaoca. Nesse subdomínio as foliações mostram uma tendência NE, com atitude média mergulhando $72^{\circ}$ para o azimute $332^{\circ}$ (Fig. 6.5). Esse padrão sugere que as foliações nos granitóides são relativamente mais jovens e, portanto, foram rotacionadas em menor intensidade para direção da zona de cisalhamento. As lineações de estiramento nesse subdominio foram identificadas somente em lascas metassedimentares intercaladas tectonicamente e apresentam atitude média de $049 \% 21$.

Medidas sistemáticas de fraturas realizadas em seis afloramentos de diferentes litologias (anfibolitos, quartzitos, filitos e ultramilonitos graníticos), mostram que as fraturas säo essencialmente controladas pela anisotropia pré-existente das rochas. Essa interpretação baseia-se no fato de que em todos os afloramentos analisados ocorrem três familias principais de orientação, sendo ou paralelas ou perpendiculares à foliação milonitica. As atitudes médias a grosso modo são NE-ENE/subvertical, NWNNW/subvertical e subhorizontal (Fig. 6.6). Nota-se também que as atitudes desses grupos principais seguem a inflexão regional da ZCR. Onde as foliações miloníticas tem tendência ENE, as famílias subverticais de fraturas orientam-se ENE e NNW (M173, M183, M201, M209, M224 - Fig. 6.6). Onde a tendência da foliação é NE, as fraturas subverticais orientam-se NE e NW (M216 - Fig. 6.6).

\subsubsection{Zona de Cisalhamento Lancinha (trecho entre Eldorado e Itapeúna)}

A Zona de Cisalhamento Lancinha, no trecho entre as cidades de Eldorado e Itapeúna, é identificada principalmente pela ocorrência de brechas cataclásticas e protomilonitos derivados de rochas graníticas do Maciço de Itapeúna. A foliação média obtida mergulha $81^{\circ}$ para o azimute $324^{\circ}$ (Fig. 6.7). A lineação de estiramento apresenta caimentos muito baixos para NE. Nesse caso foi obtida uma média de $050^{\circ} / 15^{\circ}$ (Fig. 6.7).

\subsubsection{Zona de Cisalhamento Eldorado}

A Zona de Cisalhamento Eldorado, identificada neste trabalho, é responsável pela separação de paragnaisses representantes do Complexo Embu, a norte, de filonitos da Seqüência Serra das Andorinhas a sul. Caracteriza-se por uma direção geral E-W e foliações subverticais, podendo ser inserida no grupo II, conforme descrito acima. As foliações medidas em campo apresentam atitude média com mergulho de $84^{\circ}$ para 0 azimute $348^{\circ}$ (Fig. 6.7). As lineações de estiramento mostram-se bem dispersas. 
Enquanto na maioria dos afloramentos dominam caimentos moderados a altos, no afloramento M075, onde ocorrem tipicos milonitos, predominam caimentos baixos (Fig. 6.7).

\subsubsection{Zonas de Cisalhamento Figueira, Agudos Grandes e Barra do Batatal}

As zonas de cisalhamento Figueira, Agudos Grandes e Barra do Batatal apresentam foliações com atitudes variadas refletindo a rotação da posição original NE para direção ENE, devido a influência da ZCR (Fig. 6.7). As lineações de estiramento mostram caimentos variando desde posições de máximo mergulho até subhorizontais (Fig. 6.7), também evidenciando uma rotação posterior a suas gerações. 

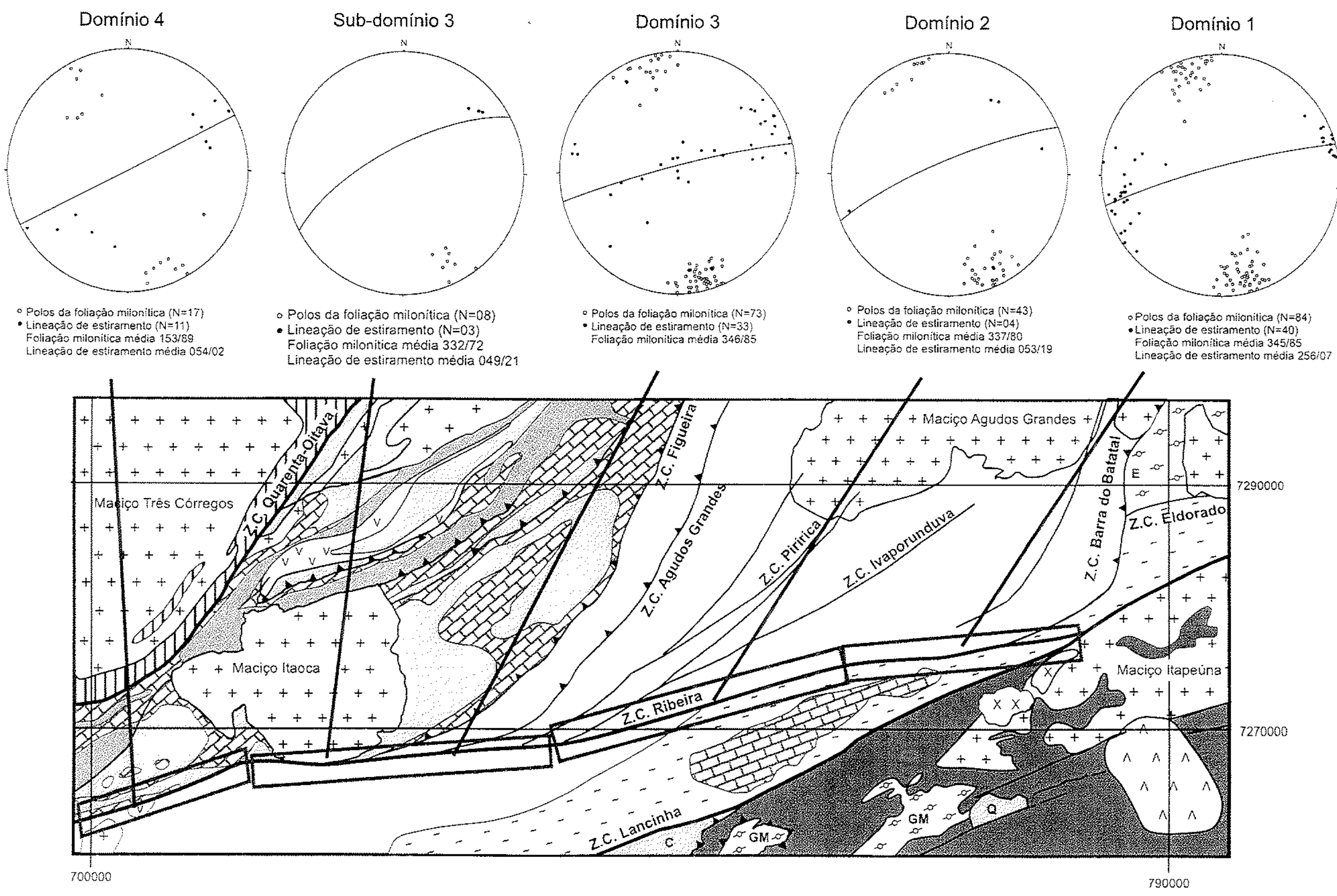

Figura 6.5. Mapa de distribuição dos domínios estruturais da Zona de Cisalhamento Ribeira. 


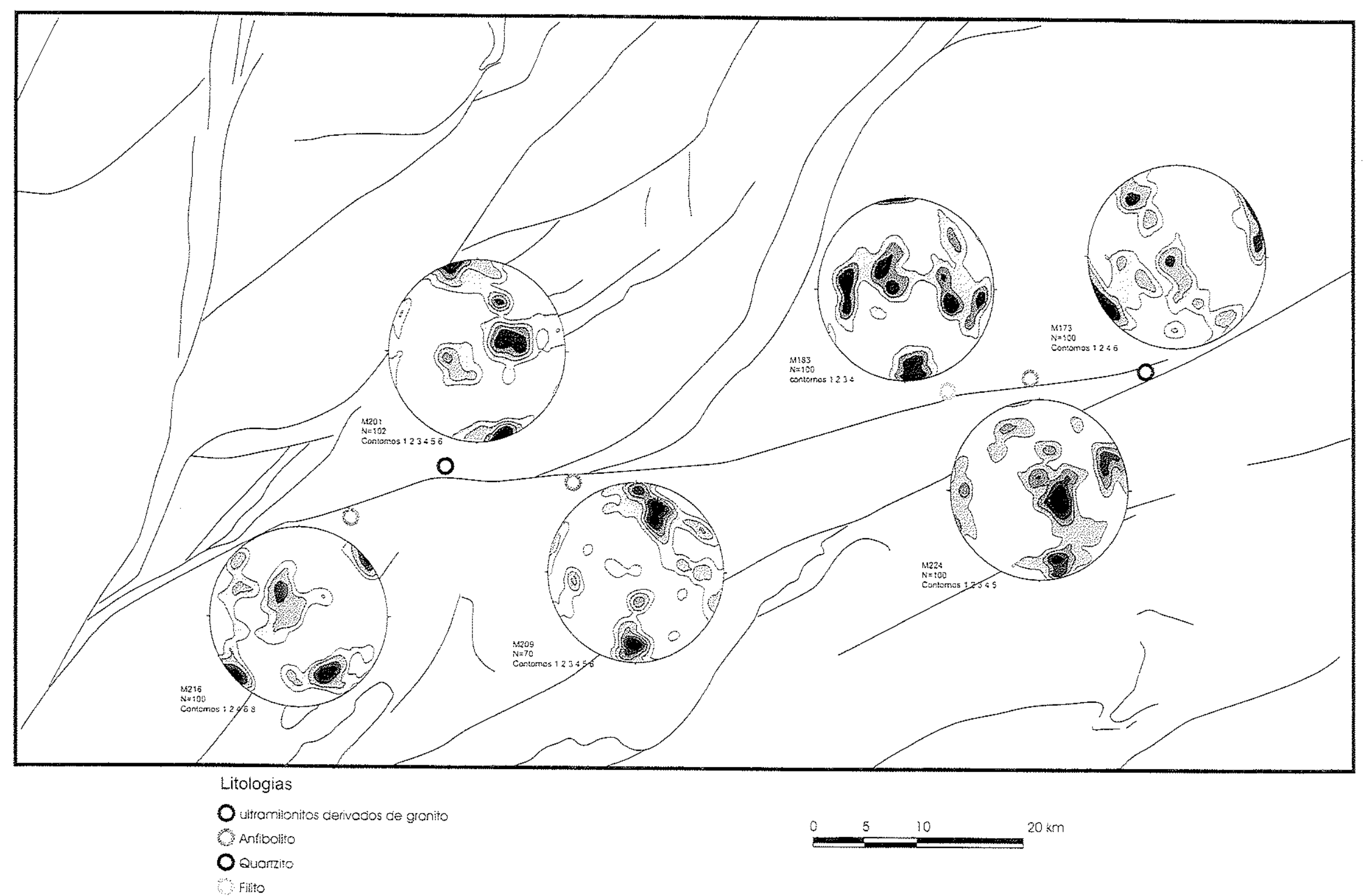




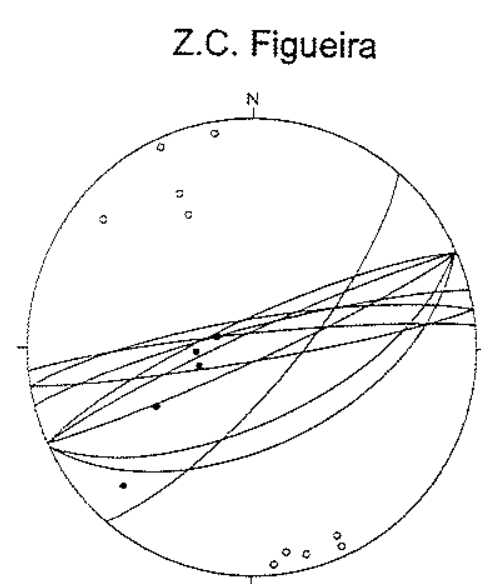

- Poios da foliação milonítica $(\mathrm{N}=10)$

- Lineação de estiramento $(N=5)$
Foliaça milonitica média $349: 84$
Z.C. Agudos Grandes

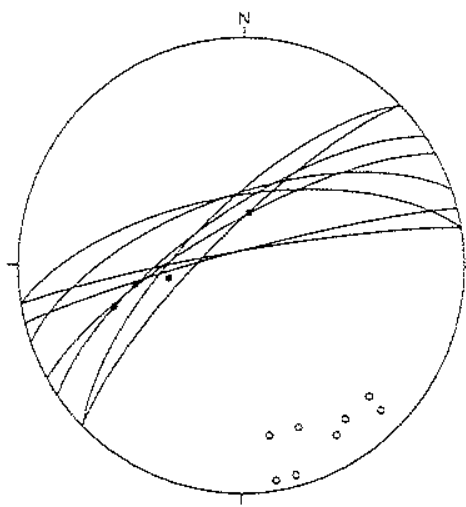

- Polos da foliaçăo milonitica ( $(\vdots=8)$ - Lineação de estiramento $(\mathrm{N}=4$ )
Z.C. Barra do Batatal

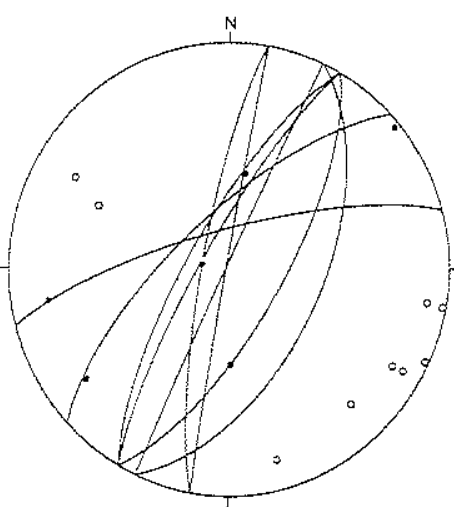

- Poios daa :oliação milcnitica $(N=9)$

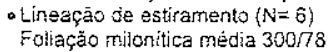

Z.C. Lancinha

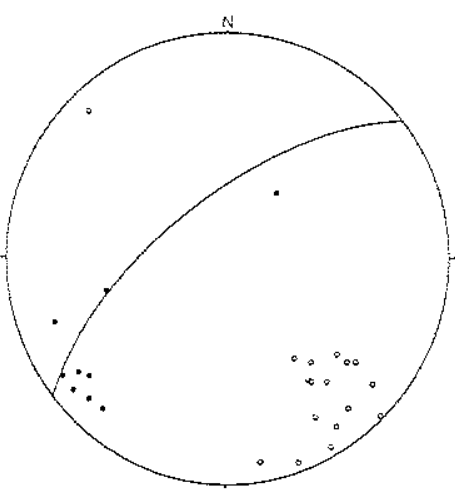

- Polos da folizçăo milonitica $(\mathrm{N}=23)$ - Lineaçäo de estiramento $(\hat{N}=8)$ folkaçáo milonitica média $321 / 75$
Z.C. Eldorado

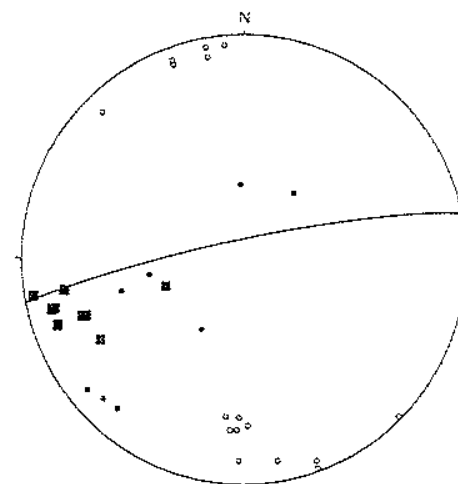

- Polos da foliaçăc mionitica $(\hat{N}=17)$ - Lineaçás de estramento $(\mathrm{N}=\mathrm{N})$

( Lineaçăo de estiramentio mếdia 253/22

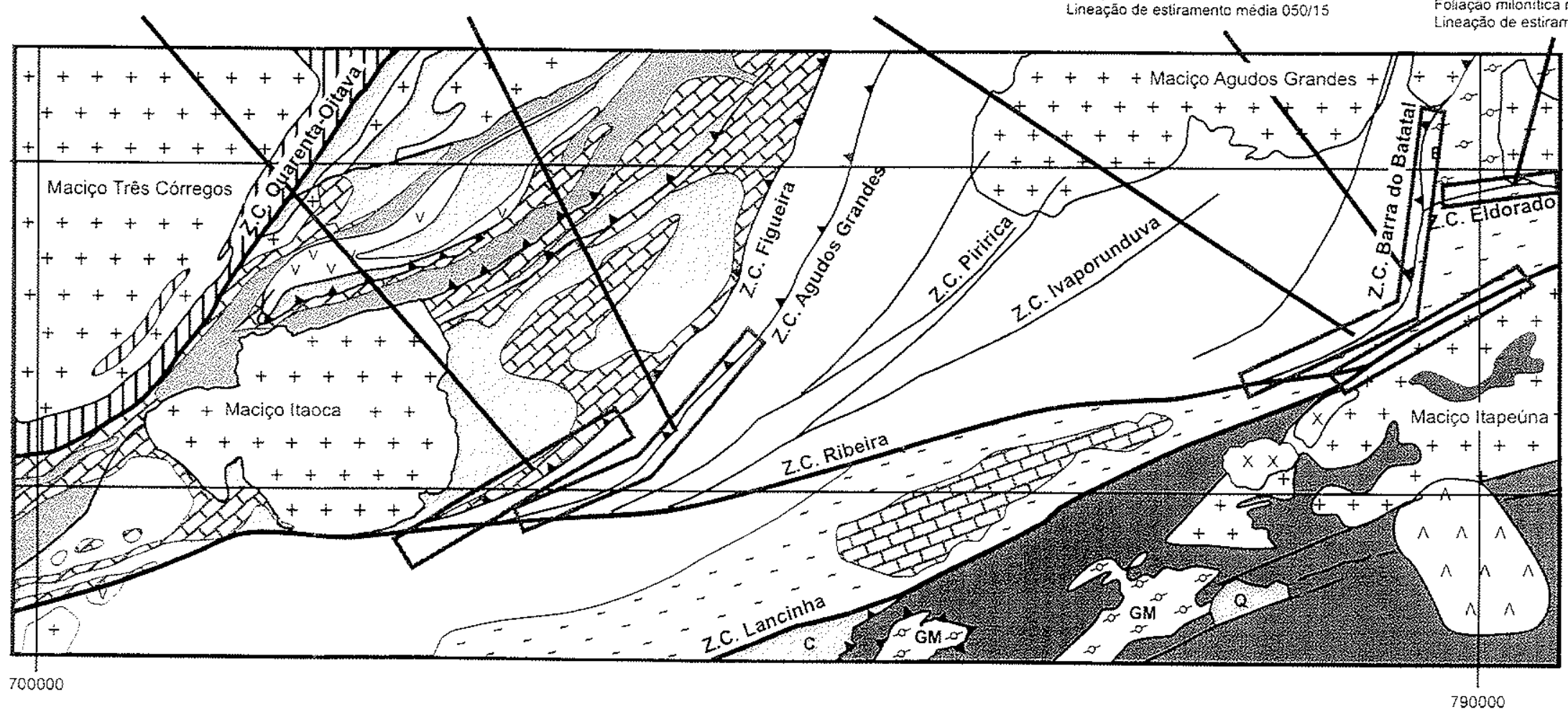

Figura 6.7. Dominios estruturais das zonas de cisalhamento associadas com a ZCR. 


\section{INDICADORES CINEMÁTICOS}

\subsection{Zona de Cisalhamento Ribeira}

A Zona de Cisalhamento Ribeira apresenta diversos indicadores cinemáticos seguros nas escalas macro, meso e microscópicas.

A inflexão regional das estruturas pela ZCR mostra um nítido arrasto destral, como pode ser observado no mapa geológico (Anexo 1, Fig. 4.2), em fotografias aéreas ou em imagens de radar.

Os indicadores cinemáticos mesoscópicos consistem de fragmentos e boudins rotacionados, dobras assimétricas e veios extensionais. Todos esses critérios indicam sistematicamente movimentação destral. Os veios extensionais, geralmente formados por quartzo, apresentam orientação geral N45W/subvertical (Fig. 10.3B), sendo consistentes com uma deformação por cisalhamento simples destral, uma vez que a ZCR apresenta direção ENE.

Os diversos indicadores cinemáticos observados na escala microscópica também mostram sistematicamente uma movimentação destral. Tais indicadores compreendem pares de foliações SC (Lister \& Snoke, 1984) e SC 1 (Ramsay \& Lisle, 2000), porfiroclastos e porfiroblastos rotacionados (Passchier \& Simpson, 1986; Ramsay \& Huber, 1987), assimetria de tramas de eixo-c de quartzo (e.g. Lister \& Hobbs, 1980). Exemplos de indicadores microscópicos observados são mostrados na figura 7.1. As tramas cristalográficas assimétricas são apresentadas na figura 9.1.

As estruturas $\mathrm{SC}_{1}$, conforme definidas por Ramsay \& Lisle (2000), merecem discussão mais detalhada pelo fato de poderem ser interpretadas como resultantes de movimentos opostos.

Segundo Ramsay \& Lisle (2000) em uma deformação por cisalhamento simples dúctil são geradas duas bandas secundárias de cisalhamento, denominadas de bandas $C_{1}$ e $C_{2}$, que são análogas às fraturas $R$ e $R^{\prime}$ de Riedel associadas com deformações rúpteis, porém, com relações angulares diferentes (Fig. 7.2).

As bandas $C_{1}$ produzem cisalhamentos extensionais em pequena escala nas camadas paralelas às bordas da zona de cisalhamento, especialmente nos leitos mais competentes. Essa movimentação é oposta àquela apresentada pelo cisalhamento simples nas estruturas $\mathrm{C}$ e pela movimentação principal da zona de cisaihamento (Figs. 7.2 e 7.3).

As bandas $\mathrm{C}_{2}$ (Fig. 7.2) apresentam baixo ângulo em relação à zona de cisalhamento simples e sentidos de deslizamento concordantes com a movimentação desta e das estruturas C (Ramsay \& Liste, 2000). 
Nas figuras $7.1 \mathrm{~A}$ e $7.1 \mathrm{~B}$ são mostradas típicas estruturas $S / C_{1}$ indicativas de movimentação destral (compare com modelo de Ramsay \& Lisle, 2000 apresentado na figura 7.3).

$O$ ângulo entre $a$ banda $C_{1}$ e a direção do cisalhamento principal decresce com a deformação cisalhante total na zona. Onde a deformação total média é de aproximadamente $\gamma=1$ (Razão de deformação ao redor de 1,4 ), as bandas $C_{1}$ tipicamente encontram-se orientadas ao redor de $60^{\circ} \mathrm{em}$ relação as paredes da zona de cisalhamento. Com o aumento do cisalhamento $(\gamma)$ e da razão de deformação, esse ângulo decresce progressivamente pela rotação das estruturas $C_{1}$ e $C_{2}$.

\subsection{Zona de Cisalhamento Lancinha}

Os indicadores cinemáticos observados na Zona de Cisalhamento Lancinha consistem de porfiroclastos rotacionados tipo $\sigma$ e pares de foliações SC. Ambos os critérios são indicativos de movimentação destral, estando compativeis com a inflexão da foliação milonítica (ver mapa geológico - Anexo 1).

\subsection{Zonas de Cisalhamento Figueira, Agudos Grandes e Barra do Batatal}

As zonas de cisalhamento Figueira, Agudos Grandes e Barra do Batatal, todas classificadas no grupo I (item 6.1), apresentam indicadores cinemáticos contraditórios.

A inflexão regional das foliações associadas a essas falhas sugerem componentes de movimentação direcional anti-horárias, visto que tais foliações apresentam tendências NE, enquanto o traço das falhas tendências NNE.

Pares de estruturas SC e porfiroclastos rotacionados do tipo $\sigma$ observados na Zona de Cisalhamento Figueira indicam componentes inversos. Considerando que nas localidades onde foram observados esse indicadores (área próxima da zona de junção com a ZCR), as lineações de estiramento caem para SW, são sugeridos componentes direcionais destrais. Entretanto, é possivel que essas lineações de estiramento foram geradas em um regime de empurrão anterior à instalação das transcorrências, de modo que teriam sido superpostas por deformações associadas a estas últimas, tornando complexa a análise cinemática.

Ressalta-se que Campanha \& Sadowski (2002) obtiveram nas zonas de cisalhamento Figueira e Agudos Grandes elipsóides de deformação com eixo $X$ caindo $50^{\circ}$ para NNW e $72^{\circ}$ para NE, sugerindo componentes direcionais anti-horários. 

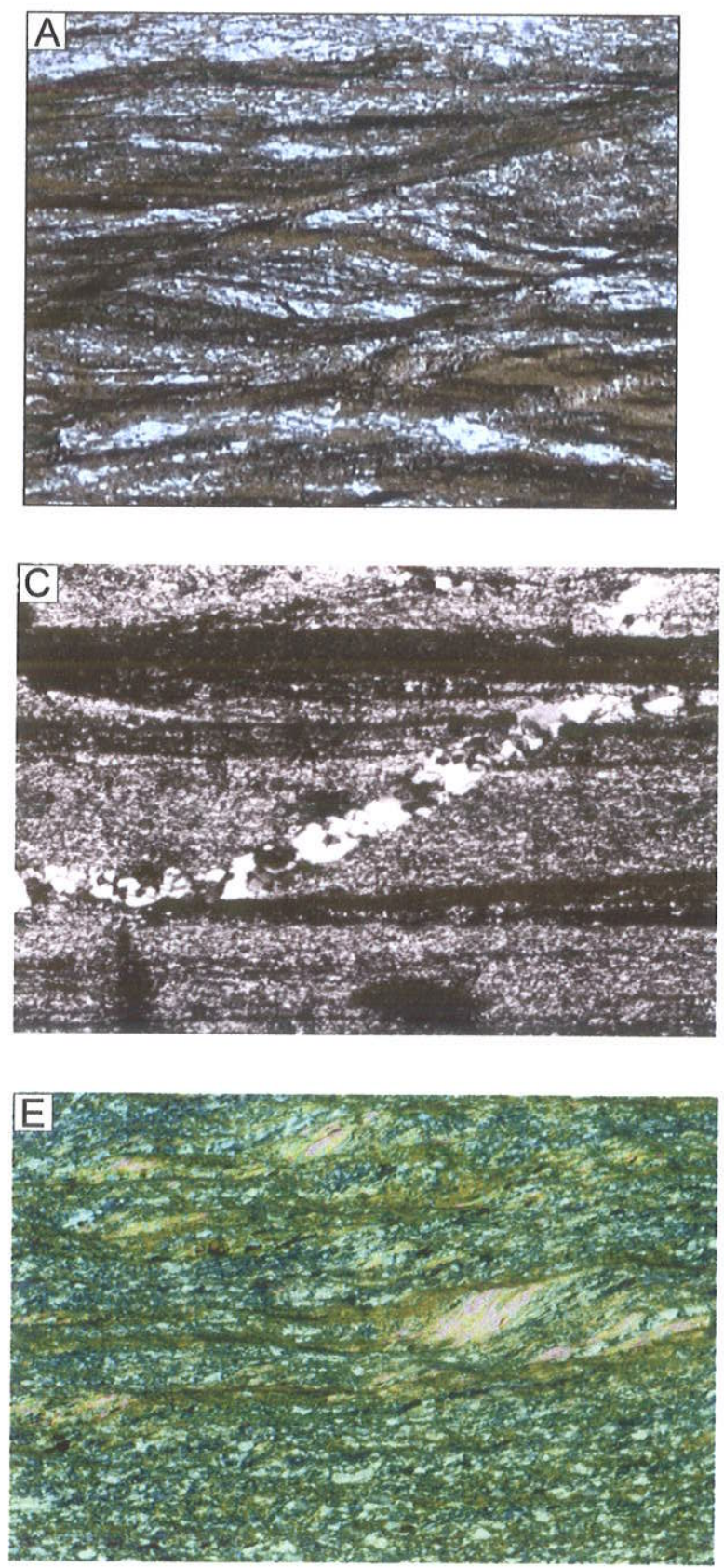
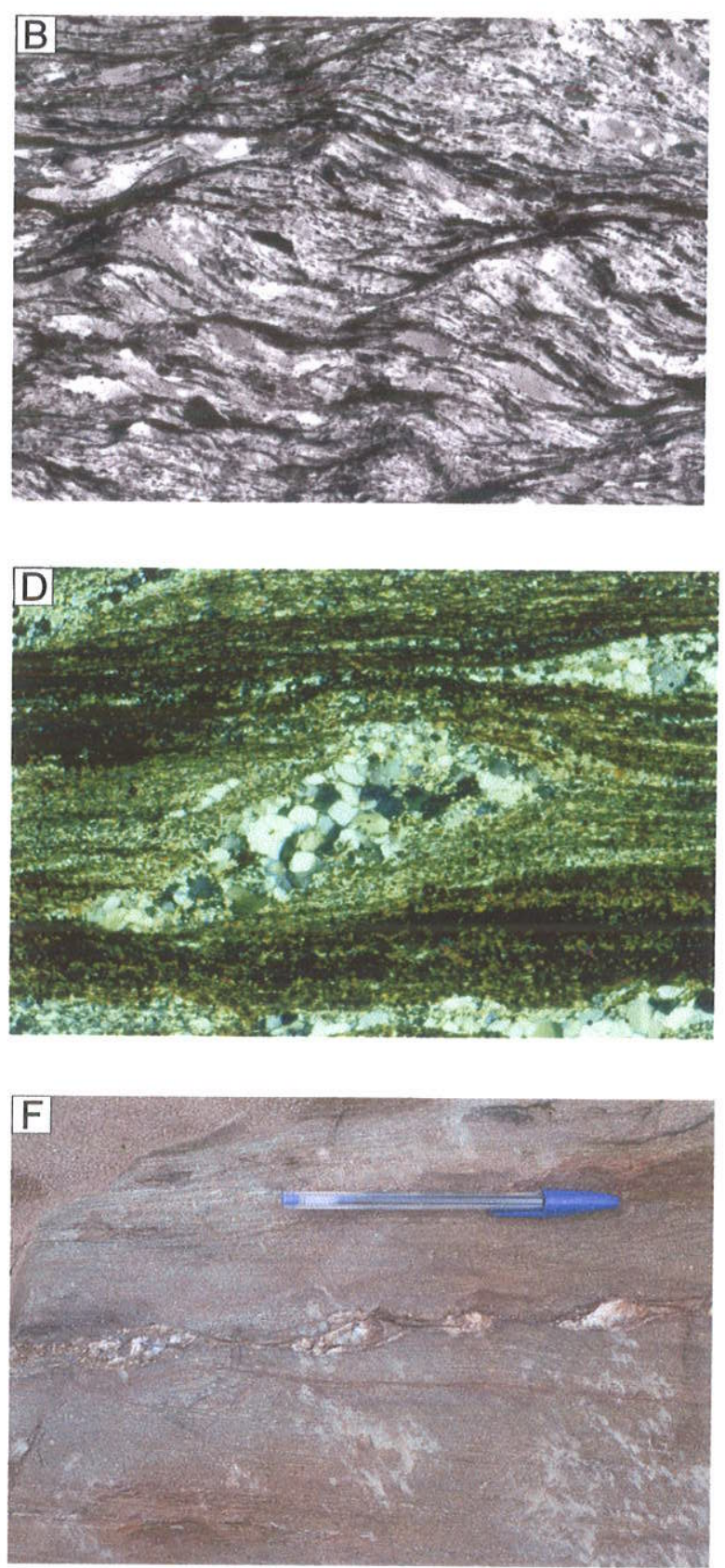

Figura 7.1. Principais indicadores cinemáticos em escala de afloramento e microscópica: (A e B) Pares de folições Sc1; (C) Vênula rotacionada; (D) porfiroclasto tipo sigma rotacionado; (E) par SC; (G) boudins rotacionados. Todos os critérios indicam movimentação destral. 

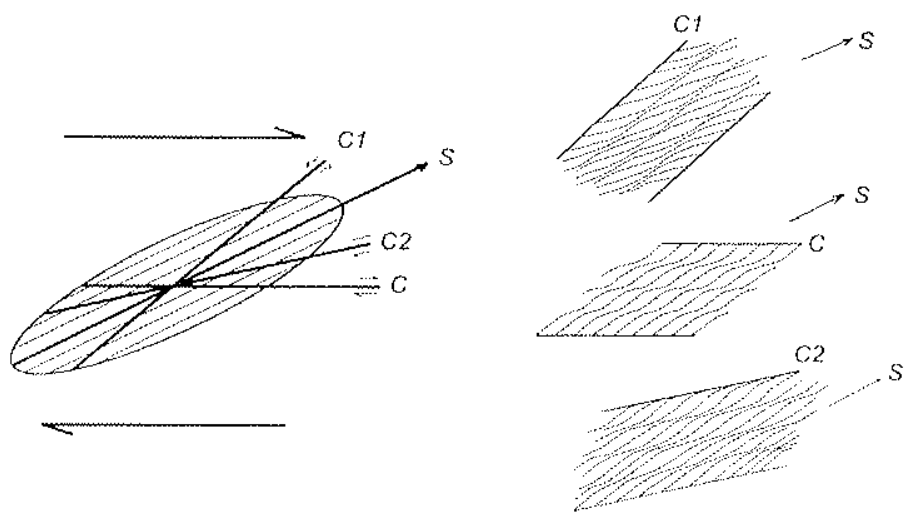

Figura 7.2. Relaçöes entre foliaçöes $S$ com diferentes bandas de cisalhamento que podem surgir durante o deslocamento em uma zona de cisalhamento simples (Ramsay \& Lisle, 2000)
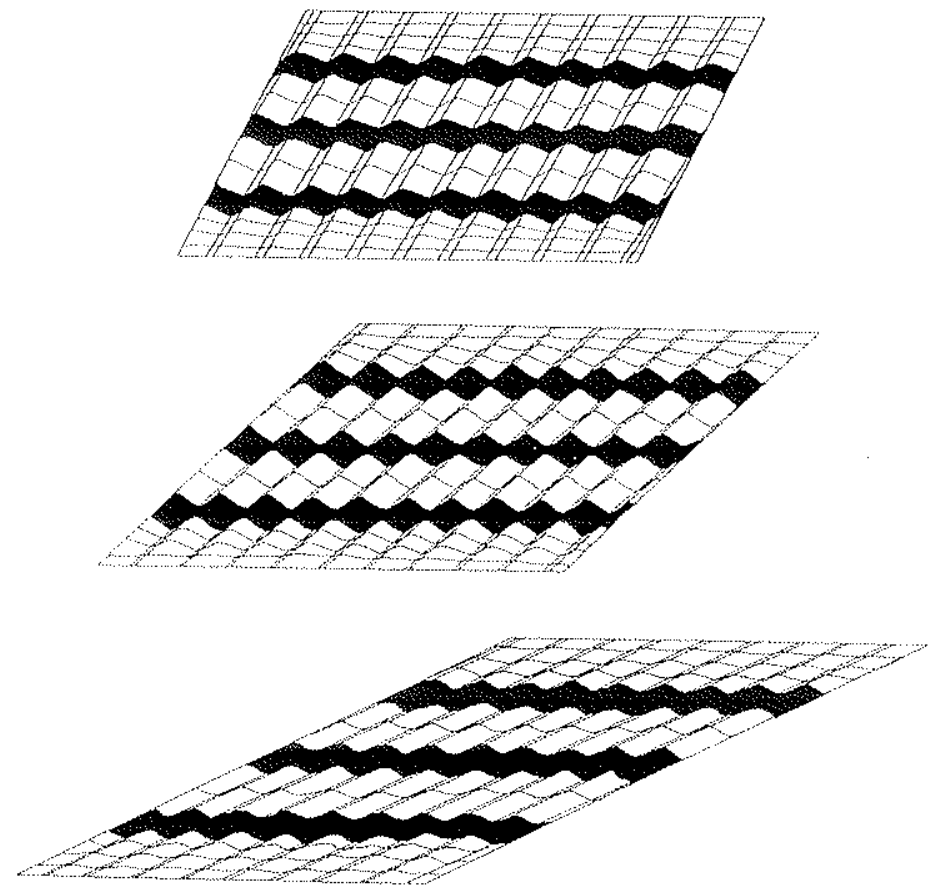

Figura 7.3. Representação diagramática das relações geométricas de desenvolvimento das bandas de cisalhamento $\mathrm{C} 1$ sinistrais em uma deformação por cisalhamento simpłes destral. Notar como o desłocamento diferencial através das bandas C1 decresce nos limites da zona C (Ramsay \& Lisłe, 2000). 


\section{ANÁLISE DA DEFORMAÇÃO FINITA}

Estimativas quantitativas da deformação finita de rochas deformadas em torno da ZCR foram realizadas a partir da aplicação dos métodos: orientação preferencial de forma (OPF) (Launeau \& Cruden, 1998), Rf/Ø̋' e média harmônica (Ramsay \& Huber, 1983). Os objetivos foram obter os tipos de elipsóide deformação e um mapa de distribuição de seus eixos principais. Os resultados foram lançados em diagramas de Flinn e mapas e confrontados com as previsões propostas pelos modelos teóricos de zonas de cisalhamento e transpressão, tais como os de Ramsay \& Graham (1970), Sanderson \& Marchini (1984), Tikoff \& Teyssier (1994), Robin \& Cruden (1994), entre outros autores.

Foi realizada uma comparação entre os resultados do método OPF e os resultados provenientes dos métodos $\mathrm{Rf} / \varnothing$ ' e média harmônica, estes últimos comumente utilizados na bibliografia. Usualmente o método OPF tem sido aplicado na dedução de tramas ígneas, não sendo encontrado na bibliografia trabalhos em que foi utilizado na obtenção de tramas metamórficas. O método básico aqui utilizado foi o cálculo do tensor de inércia da forma dos grãos (Launeau \& Cruden, 1998). Numa primeira aproximação, pode-se dizer que, se temos um grão (ou outro objeto qualquer a ser medido, como um seixo ou boudin, etc.), pode ser encontrada uma elipse (2D) ou um elipsóide (3D) que melhor se ajusta à forma do gräo.

Esse tensor é apenas descritivo da forma do objeto e não necessariamente corresponde ao tensor de deformação finita. Porém, no caso de objetos deformados, cujo estado inicial era aproximadamente equidimensional (tendendo a circular ou esférico), a elipse (elipsóide) de forma deveria aproximar-se da elipse (elipsóide) de deformação finita.

\subsection{Base Teórica}

\subsubsection{Método de Orientação Preferencial de Forma}

A razão de forma e a orientação do eixo maior de cada grão podem ser calculadas a partir do tensor de inércia de sua forma (Jähne, 1991 apud Launeau \& Cruden, 1998). São obtidas imagens raster das seções, como tais constituidas por pixe/s. Se $x_{i}$ e $y_{i}$ são as coordenadas dos pixels do grão $j$, e $A$ é sua área superficial (igual ao número de pixels) (Fig. 8.1), então o tensor de inércia $\left(\mathbf{M}_{j}\right)$, de sua forma é dado por: 


$$
\mathbf{M}_{j}=\left|\begin{array}{ll}
\mathrm{m}_{x x j} & \mathrm{~m}_{x y j} \\
\mathrm{~m}_{x y j} & \mathrm{~m}_{y y j}
\end{array}\right|
$$

onde,

$$
\begin{aligned}
& \mathrm{m}_{x x j}=1 / A \sum_{i}\left(x_{i}-x_{c}\right)^{2} \\
& \mathrm{~m}_{x y j}=1 / A \sum_{i}\left(x_{i}-x_{c}\right)^{2}\left(y_{i}-y_{c}\right) \\
& \mathrm{m}_{y y j}=1 / A \sum_{i}\left(y_{i}-y_{c}\right)^{2}
\end{aligned}
$$

são os componentes do tensor e,

$x_{c}=1 / A \sum_{i} x_{i}$

$y_{c}=1 / A \sum_{i} y_{i}$

são coordenadas do centróide do grão.

A razão de forma do grão pode ser definida como $r=\left(\lambda_{1} / \lambda_{2}\right)^{1 / 2}$ onde $\lambda_{1}$ e $\lambda_{2}$ são os autovalores de $\mathbf{M}_{j}$. Da mesma forma, a direção de máxima elongação do grão $(\Phi)$, é dada pelo maior autovetor de $\mathbf{M}_{j}$.

O tamanho do semi-eixo maior $(a)$, e do semi-eixo menor $(b)$, de uma elipse representando o grão é dado por $a=\left(\lambda_{1}\right)^{1 / 2}$ e $b=\left(\lambda_{2}\right)^{1 / 2}$ em unidade de pixels (ou em milímetros se o tamanho do pixel é conhecido).

Para correlacionar as orientações preferenciais de forma (OPF) das populações de grãos com a OPF total, introduz-se a média do tensor de inércia de $N$ formas de grãos:

$$
\mathbf{M}=1 / N \sum_{j} \mathbf{M}_{j}=1 / N\left|\begin{array}{ll}
\sum_{j} \mathrm{~m}_{x x j} & \sum_{j} \mathrm{~m}_{x y j} \\
\sum_{j} \mathrm{~m}_{x y j} & \sum_{j} \mathrm{~m}_{y y j}
\end{array}\right|
$$

que efetivamente fornece uma OPF ponderada pela área de cada grão. A razão de forma média dos grãos, $S R_{t}=\left(\lambda_{1} / \lambda_{2}\right)^{1 / 2}$ e sua orientação $\Phi$, são dadas pelos autovalores $e$ autovetores máxinios de $\boldsymbol{M}$, respectivamente. As dimensões médias $a_{t}$ e $b_{t}$ são calculadas da mesma forma. 


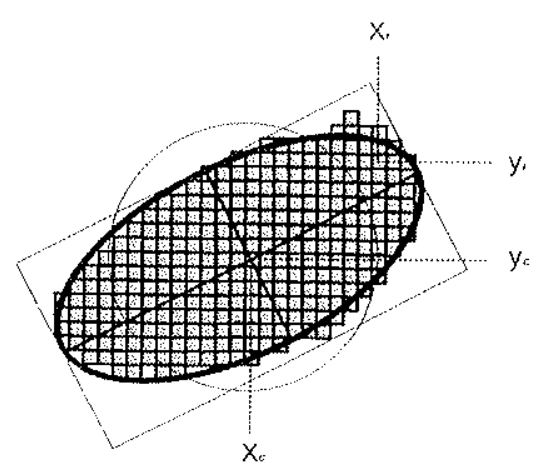

A

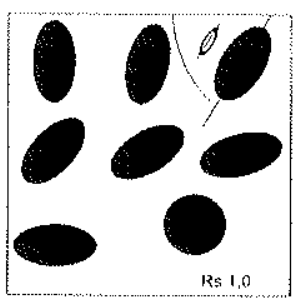

B

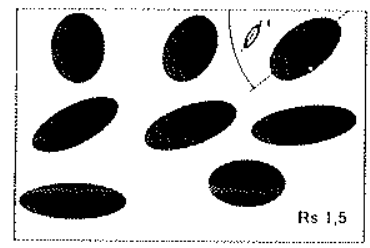

C

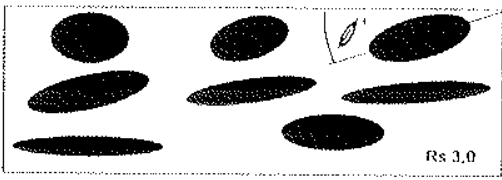

Figura 8.1. Representaçäo esquemática de uma imagem raster de um grão teórico, com o tensor de inércia ajustado. xi e yi são as coordenadas de cada pixel e xc e yc são as coordenadas do centróide do grão.
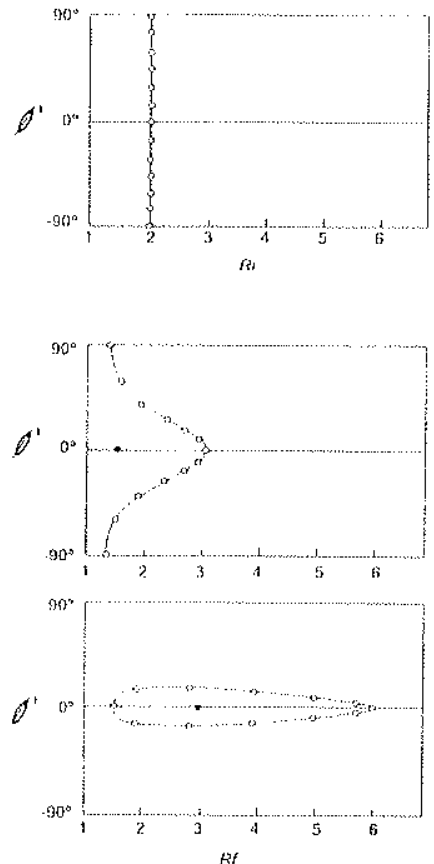

Figura 8.2. Efeitos da deformação em uma série de objetos elípticos com orientação inicial $\theta$ e elipsidade inicial Ri. Depois da deformação, cuja elipse apresenta elipsidade $\mathrm{Rs}_{\mathrm{s}}$ os marcadores originais mudam suas formas (elipsidade Rf) e orientações $\left(\theta^{\prime}\right)$.

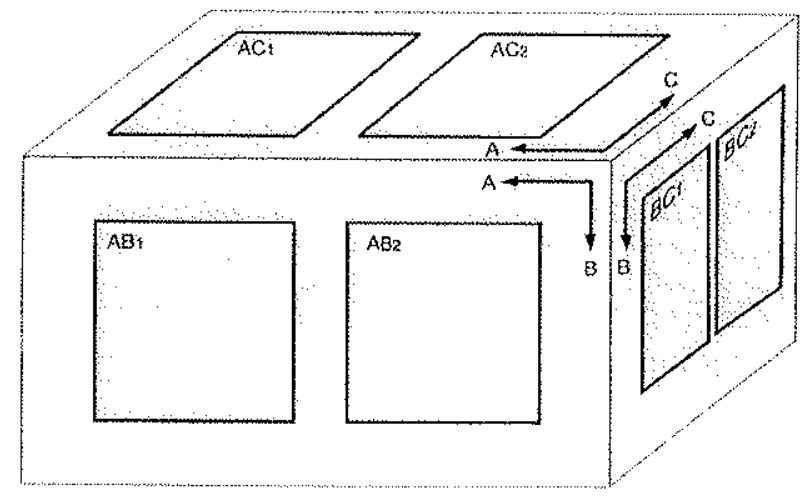

Figura 8.3. Esquema de orientação das seçōes e sub-seçöes das amostras analisadas. 


\subsubsection{Método $R_{f} / \varnothing^{\prime}$}

Quando uma elipse inicial com elipsidade $R_{i}$ é homogeneamente deformada, a forma resultante também é elíptica (Ramsay \& Huber, 1983). Dessa maneira, a forma da elipse final $\left(R_{f}\right)$ é função da forma e orientação da elipse inicial e do elipsóide de deformação.

No método $R_{f} / \varnothing^{\prime}$ o gráfico relacionando a $R_{f}$ com a orientação final dos eixos maiores das elipses $\left(\varnothing^{\prime}\right)$, é a chave para a análise da geometria de marcadores elípticos deformados $e$, proporciona um excelente meio de separação dos componentes de deformação tectônica das formas iniciais dos marcadores (Ramsay \& Huber, 1983). A construção desse gráfico necessita dos valores de elipsidade dos grãos e da orientação dos eixos maiores com relação a uma linha de referência. No gráfico $R_{f} / \varnothing$ os pontos devem apresentar uma distribuição simétrica ao redor da direção do eixo maior da elipse de deformação e, em cada curva, os pontos derivados de um grupo de elipses inicialmente orientadas aleatoriamente tendem a se concentrar na direção dos maiores valores de $R_{f}$. Duas situações principais podem ocorrer:

1) Se a $R_{l}$ máxima for maior que a $R_{S}$ os pontos devem apresentar uma flutuação de $180^{\circ} \mathrm{em} \varnothing^{\prime}$ (Fig. 8.2B), de forma que os dados concentrar-se-ão ao redor do valor de $R_{f}$ máximo. A direção dessa concentração máxima de dados corresponde a orientação do eixo maior da elipse de deformação.

A distribuição dos dados deve ser simétrica em relação à direção de concentração máxima, caso contrário, deveria existir orientação preferencial dos objetos antes da deformação.

Os valores de elipsidades máxima e minima apresentam relações matemáticas especiais:

$$
\begin{aligned}
& R_{f} \text { máximo }=R_{s} \cdot R_{i} \text { máximo } \\
& R_{f} \text { mínimo }=R_{i} \text { máximo } / R_{s} \\
& \left(R_{f} \text { máximo } R_{f} \text { mínimo }\right)^{1 / 2}=R_{i} \text { máximo } \\
& \left(R_{f} \text { máximo } / R_{f} \text { minimo }\right)^{1 / 2}=R_{s}
\end{aligned}
$$

2) Se a $R_{i}$ máxima for menor que a $R_{s}$, os dados mostrarão uma flutuação menor que $90^{\circ} \mathrm{em} \varnothing^{\prime}$ (Fig. 8.2C). A freqüência máxima de orientação nesse caso coincide com a orientação do eixo maior da elipse de deformação e a distribuição dos dados deve ser simétrica em relação a esta direção.

Nesse caso, as caracteristicas dos valores máximos e mínimos de $R_{f}$ são dados por: 


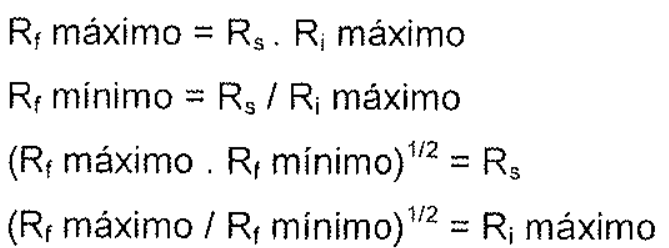

Ramsay \& Huber (1983) compararam os resultados de $R_{s}$ obtidos a partir do método $R_{f} / \varnothing^{\prime} \mathrm{com}$ aqueles provindos das médias aritmética, geométrica e harmônica dos valores de elipsidade de objetos deformados. Assim, os autores concluíram que as duas últimas médias fornecem aproximaçōes satisfatórias para uma rápida determinação da deformação tectônica. Não existe uma razão lógica para a escolha da média harmônica, exceto que esta fornece valores menores de $R_{s}$ em relação àqueles obtidos pelas outras médias, embora possa apresentar valores maiores que o $R_{f} / \varnothing^{\prime}$.

\subsubsection{Cálculo de elipsóides a partir das elipses de três seçōes perpendiculares}

Quando uma seção bidimensional de análise é grande o bastante para representar a distribuição de uma população de grãos, um conjunto de seções paralelas de uma amostra deve fornecer exatamente a mesma anisotropia, tanto em dimensão quanto orientação (caso contrário, um grande número de seções devem ser analisadas). A partir dos tensores quadráticos bidimensionais de uma amostra calculados em três seções ortogonais, os coeficientes resultantes podem ser combinados para calcular o tensor quadrático tridimensional do elipsóide correspondente (Launeau \& Cruden, 1998).

Uma vez conhecendo-se $a_{t}$ e $b_{t}$, os eixos médios maior e menor de um objeto elíptico teórico, com a orientação do eixo maior $\left(\alpha_{x}\right)$, medido em relação à direção $x \mathrm{em}$ um plano xy, o tensor quadrático 2-D de forma é dado por:

$$
\begin{aligned}
& \left|\begin{array}{cc}
\cos \alpha_{x} & -\operatorname{sen} \alpha_{x} \\
\operatorname{sen} \alpha_{x} & \cos \alpha_{x}
\end{array}\right| \times\left|\begin{array}{cc}
1 / a_{t}^{2} & 0 \\
0 & 1 / b_{t}^{2}
\end{array}\right| \times\left|\begin{array}{cc}
\cos \alpha_{x} & \operatorname{sen} \alpha_{x} \\
-\operatorname{sen} \alpha_{x} & \cos \alpha_{x}
\end{array}\right|=S_{x y} \\
& \text { e } \\
& \left|\begin{array}{cc}
x x_{x y} & x y_{x y} \\
x y_{x y} & y y_{x y}
\end{array}\right|=S_{x y}
\end{aligned}
$$

O mesmo procedimento é usado para calcular os tensores 2-D nos planos $x z$ e yz. O tensor de forma quadrático 3-D pode ser calculado diretamente como segue: 


$$
S_{3 D}=\left|\begin{array}{ccc}
\left(x x_{x z}+x x_{x y}\right) / 2 & x y_{x y} & x z_{x z} \\
x y_{x y} & \left(y y_{x y}+y y_{y z}\right) / 2 & y z_{y z} \\
x z_{x z} & y z_{y z} & \left(z z_{x z}+z z_{y z}\right) / 2
\end{array}\right|
$$

Os inversos das raizes quadradas dos autovalores de $S_{3 D}$ fornecem as intensidades $a, b$ e $c$ do elipsóide e suas orientações são dadas pelos três autovetores correspondentes.

O programa ELLIPSOID 2001 (Launeau \& Robin, 2001, inédito), que utiliza a base teórica discutida acima, permite uma boa avaliação do erro provindo das determinações das elipses médias de cada seção de uma amostra. Para tal, cada uma das seções a serem analisadas ( $A B, A C$ e $B C$ ), são subdivididas em duas subseções (Fig. 8.3). Em cada uma das subseções é calculada uma elipse, de forma que são geradas seis elipses $\left(A B_{1}, A B_{2}, A C_{1}, A C_{2}, B C_{1}, B C_{2}\right)$. As combinações possiveis entre estas seis elipses fornecem oito elipsóides para uma mesma amostra:

$$
\begin{aligned}
& A B_{1} A C_{1} B C_{1} \\
& A B_{1} A C_{1} B C_{2} \\
& A B_{1} A C_{2} B C_{1} \\
& A B_{1} A C_{2} B C_{2} \\
& A B_{2} A C_{1} B C_{1} \\
& A B_{2} A C_{1} B C_{2} \\
& A B_{2} A C_{2} B C_{1} \\
& A B_{2} A C_{2} B C_{2}
\end{aligned}
$$

A compatibilização entre as três seções é realizada a partir da comparação entre os oito elipsóides obtidos de cada amostra. A partir desses elipsóides, o programa calcula um elipsóide médio.

Outra vantagem do programa é a possibilidade em se trabalhar com seções que não correspondem às seções principais do elipsóide de deformação.

\subsection{Procedimentos adotados}

O procedimento utilizado consistiu na determinação das elipses de deformação em duas ou três seções perpendiculares a subperpendiculares entre si de cada amostra. A partir das três elipses (2D) deduziu-se o elipsóide (3D) de deformação.

No campo foram determinadas as elipsidades e relações angulares de clastos de um afloramento de metaconglomerado (F198), nas seções $X Z$ e $Y Z$ do elipsóide de 
deformação finita. Os dados foram lançados em diagramas relacionando as elipsidades dos grãos com suas orientações e as elipses de cada seção calculadas pelos métodos Rf/Ø' e média harmônica.

No mais, foram coletadas em campo oito amostras orientadas, sendo duas de metaconglomerados (M193A e M193B), três de metassiltitos (M183, M186 e M206A), uma de quartzito (M215), uma de granito (M51) e uma de veio de quartzo milonitizado (M23). Posteriormente cada amostra foi cortada em três seções mutuamente perpendiculares onde foram marcados três eixos de referência $(A, B$ e $C$ - dois eixos por plano - Fig. 8.3).

As amostras de metaconglomerados e de granito (M193A, M193B e M51) foram cortadas com serra, e os clastos das seções $A B, A C$ e $B C$ de cada amostra foram desenhados manualmente através de um overlay, sendo posteriormente escanerizados $e$ digitalizados no programa CorelDraw.

Para as amostras de metarenitos e metassiltitos (M23, M183, M186, M206A e M215) preparou-se uma seção delgada para cada corte, totalizando treze lâminas. Em cada lâmina capturou-se imagens por meio de uma câmera CCD acoplada a um microscópio óptico, que transmite a imagem no formato raster ao microcomputador. No microcomputador foram digitalizados cerca de 40 a 100 grãos de quartzo em cada subseção, utilizando-se o programa CorelDraw.

A partir das imagens digitalizadas as elipses de distribuição das tramas de cada seção, foram determinadas pelos métodos do tensor de inércia (OPF), Rf/Ø' e média harmônica, com o auxílio do programa SPO2002 de Launeau \& Robin (2002, inédito).

Os resultados bidimensionais obtidos das três seções de cada amostra foram combinados no programa ELLIPSOID2001 (Launeau \& Robin, inédito), construindomse os elipsóides de distribuição das tramas minerais de cada amostra.

\subsection{Discussão}

\subsubsection{Apresentação dos resultados}

Os resultados das elipses e dos elipsóides obtidos pelos três métodos são apresentados nas tabelas 8.1 e 8.2 .

De maneira geral, os resultados provenientes de OPF mostram-se com valores de deformação mais baixos que aqueles obtidos pelos métodos $R_{\sharp} / \varnothing^{\prime}$ e média harmônica, conforme pode ser observado pelos valores de $K$ e $R_{s} x z$ mostrados na tabela 8.2. Já os valores resultantes dos métodos $R_{f} / \varnothing$ e média harmônica mostram-se bem próximos. 
A disposição dos dados de elipsidade e relações angulares dos objetos lançados nos gráficos $R_{f} / \varnothing^{\prime}$ (Figs. 8.4 a 8.11 ), indica que esses seriam originalmente elipticos. Dessa forma, preferimos utilizar nas nossas interpretações sobre aspectos deformacionais os resultados provenientes do método $R_{f} / \varnothing$, em vista deste ser um meio mais adequado de separação entre os componentes de deformação tectônica e as formas iniciais dos marcadores.

\begin{tabular}{|c|c|c|c|c|c|c|c|c|c|c|c|c|}
\hline \multirow{3}{*}{ Amostra } & \multicolumn{12}{|c|}{ Seções } \\
\hline & \multicolumn{4}{|c|}{$\mathrm{AB}$} & \multicolumn{4}{|c|}{$\mathrm{AC}$} & \multicolumn{4}{|c|}{$\mathrm{BC}$} \\
\hline & $\begin{array}{l}\text { Sub- } \\
\text { Seçöes }\end{array}$ & $O P F$ & $R / \emptyset^{\prime}$ & $M H$ & $\begin{array}{c}\text { Sub- } \\
\text { Seçöes }\end{array}$ & OPF & $R / \emptyset^{\prime}$ & $M H$ & $\begin{array}{c}\text { Sub- } \\
\text { Secöes }\end{array}$ & $O P F$ & $R / \emptyset^{\prime}$ & $M H$ \\
\hline M23 & & 6.793 & 7,248 & 7.235 & & & & & & & & \\
\hline M51 & $\begin{array}{l}1 \\
2\end{array}$ & $\begin{array}{l}1,872 \\
1,762\end{array}$ & $\begin{array}{l}2,270 \\
2,053\end{array}$ & $\begin{array}{l}2,057 \\
2,043\end{array}$ & $\begin{array}{l}1 \\
2\end{array}$ & $\begin{array}{l}2,230 \\
2,052\end{array}$ & $\begin{array}{l}2,536 \\
2,358\end{array}$ & $\begin{array}{l}2,561 \\
2,384\end{array}$ & $\begin{array}{l}1 \\
2\end{array}$ & $\begin{array}{l}1,216 \\
1,192\end{array}$ & $\begin{array}{l}1,506 \\
1,575\end{array}$ & $\begin{array}{l}1,712 \\
1,645\end{array}$ \\
\hline$M 183$ & $\begin{array}{l}1 \\
2\end{array}$ & $\begin{array}{l}1,28 \\
1,31\end{array}$ & $\begin{array}{l}1,525 \\
1.573\end{array}$ & $\begin{array}{l}1,517 \\
1.542\end{array}$ & $\begin{array}{l}1 \\
2\end{array}$ & $\begin{array}{l}1,844 \\
1,872\end{array}$ & $\begin{array}{l}1,872 \\
2,004\end{array}$ & $\begin{array}{l}1,916 \\
1,903\end{array}$ & $\begin{array}{l}1 \\
2\end{array}$ & $\begin{array}{l}1,431 \\
1,478\end{array}$ & $\begin{array}{l}1,715 \\
1,674\end{array}$ & $\begin{array}{l}1,675 \\
1,619\end{array}$ \\
\hline M186 & $\begin{array}{l}1 \\
2\end{array}$ & $\begin{array}{c}1,326 \\
1,26\end{array}$ & $\begin{array}{l}1,573 \\
1,472\end{array}$ & $\begin{array}{l}1.533 \\
1,496\end{array}$ & $\begin{array}{l}1 \\
2\end{array}$ & $\begin{array}{l}1,250 \\
1,262\end{array}$ & $\begin{array}{l}1,465 \\
1,673\end{array}$ & $\begin{array}{l}1,504 \\
1,568\end{array}$ & $\begin{array}{l}1 \\
2\end{array}$ & $\begin{array}{l}1,582 \\
1,531\end{array}$ & $\begin{array}{l}1,623 \\
1,685\end{array}$ & $\begin{array}{l}1,682 \\
1,687\end{array}$ \\
\hline M193A & $\begin{array}{l}1 \\
2\end{array}$ & $\begin{array}{l}1,285 \\
1,407\end{array}$ & $\begin{array}{l}1,738 \\
1,788\end{array}$ & $\begin{array}{l}1,738 \\
1,802\end{array}$ & $\begin{array}{l}1 \\
2\end{array}$ & $\begin{array}{l}1,409 \\
1,278\end{array}$ & $\begin{array}{l}1,872 \\
1,855\end{array}$ & $\begin{array}{l}1,830 \\
1,772\end{array}$ & $\begin{array}{l}1 \\
2\end{array}$ & $\begin{array}{l}1,205 \\
1,300\end{array}$ & $\begin{array}{l}1,741 \\
1,599\end{array}$ & $\begin{array}{l}1,596 \\
1,596\end{array}$ \\
\hline M193B & $\begin{array}{l}1 \\
2\end{array}$ & $\begin{array}{l}1,61 \\
1,47\end{array}$ & $\begin{array}{l}1.930 \\
1.816\end{array}$ & $\begin{array}{l}1,792 \\
1,713\end{array}$ & $\begin{array}{l}1 \\
2\end{array}$ & $\begin{array}{l}1,48 \\
1,42\end{array}$ & $\begin{array}{l}1,646 \\
1,738\end{array}$ & $\begin{array}{l}1,646 \\
1,764\end{array}$ & $\begin{array}{l}1 \\
2\end{array}$ & 1,24 & 1,463 & 1,458 \\
\hline M206A & $\begin{array}{l}1 \\
2\end{array}$ & $\begin{array}{l}1,45 \\
1,47\end{array}$ & $\begin{array}{l}1,694 \\
1,647\end{array}$ & $\begin{array}{l}1,643 \\
1,664\end{array}$ & $\begin{array}{l}1 \\
2\end{array}$ & $\begin{array}{l}1,22 \\
1,26\end{array}$ & $\begin{array}{l}1,511 \\
1,455\end{array}$ & $\begin{array}{l}1,514 \\
1,425\end{array}$ & $\begin{array}{l}1 \\
2\end{array}$ & $\begin{array}{l}1,65 \\
1.69\end{array}$ & $\begin{array}{l}1,674 \\
1,781\end{array}$ & $\begin{array}{l}1,774 \\
1,760\end{array}$ \\
\hline$M 215$ & $\begin{array}{l}1 \\
2\end{array}$ & $\begin{array}{l}1,30 \\
1,39\end{array}$ & $\begin{array}{l}1,549 \\
1,605\end{array}$ & $\begin{array}{l}1,516 \\
1,598\end{array}$ & $\begin{array}{l}1 \\
2\end{array}$ & $\begin{array}{l}1,79 \\
2,03\end{array}$ & $\begin{array}{l}2,210 \\
2,205\end{array}$ & $\begin{array}{l}2,021 \\
2,051\end{array}$ & $\begin{array}{l}1 \\
2\end{array}$ & $\begin{array}{l}1,61 \\
1,67\end{array}$ & $\begin{array}{l}1,999 \\
1,817\end{array}$ & $\begin{array}{l}1.846 \\
1.806\end{array}$ \\
\hline F198 & 1 & - & 1,067 & 1.044 & 1 & - & 2,755 & 2,295 & 1 & - & 2,582 & 2,198 \\
\hline
\end{tabular}

Tabela 8.1. Comparação entre os resultados bidimensionais de $R_{\mathrm{s}}$ obtidos pelos três métodos em cada subseção. 


\begin{tabular}{|c|c|c|c|c|c|c|c|c|c|}
\hline \multicolumn{10}{|c|}{ OPF } \\
\hline \multirow{2}{*}{ Amostra } & \multirow[b]{2}{*}{ Plano $X Y$} & \multicolumn{3}{|c|}{ Valores dos eixos principais } & \multicolumn{3}{|c|}{ Atitudes dos eixos principais } & \multirow[b]{2}{*}{$x / Z$} & \multirow[b]{2}{*}{$\mathrm{k}$} \\
\hline & & $x$ & $Y$ & z & $\mathrm{x}$ & Y & z & & \\
\hline Mo51 & $318 / 95$ & 1,400 & 1,106 & 0.645 & $352 / 61$ & $235 / 15$ & $138 / 25$ & 2,170 & 0,372 \\
\hline M183 & $350 / 69$ & 1,336 & 1,038 & 0,721 & $062 / 40$ & $280 / 42$ & $\{70 / 21$ & 1,853 & 0,653 \\
\hline M186 & $347 / 86$ & 1,274 & 0,987 & 0.795 & $308 / 84$ & $076 / 03$ & $167 / 04$ & 1.603 & 1.201 \\
\hline M193A & $153 / 23$ & 1.260 & 0,946 & 0,839 & $216 / 11$ & $122 / 20$ & $333 / 67$ & 1,502 & 2,599 \\
\hline M193B & $111 / 31$ & 1,392 & 0,880 & 0,816 & $029 / 03$ & $121 / 30$ & $294 / 59$ & 1,706 & 7,413 \\
\hline M206A & $160 / 62$ & 1,279 & 1,052 & 0.743 & $225 / 39$ & $095 / 39$ & $340 / 28$ & 1,721 & 0,518 \\
\hline M215 & $337 / 60$ & 1,477 & 1.013 & 0,669 & $044 / 34$ & $277 / 42$ & $157 / 30$ & 2,208 & 0,892 \\
\hline \multicolumn{10}{|c|}{$\mathrm{R}_{f} / \varnothing^{\prime}$} \\
\hline \multirow{2}{*}{ Amostra } & \multirow{2}{*}{ Plano $X Y$} & \multicolumn{3}{|c|}{ Valores dos eixos principais } & \multicolumn{3}{|c|}{ Atitudes dos eixos principais } & \multirow{2}{*}{$X / Z$} & \multirow{2}{*}{$\mathrm{K}$} \\
\hline & & $\mathrm{x}$ & Y & $z$ & $x$ & $\mathrm{Y}$ & $z$ & & \\
\hline M051 & $317 / 65$ & 1,592 & 1.086 & 0,579 & $011 / 51$ & $241 / 27$ & $137 / 26$ & 2,749 & 0.532 \\
\hline M183 & $350 / 69$ & 1,505 & 1,006 & 0.661 & $056 / 48$ & $276 / 35$ & $170 / 21$ & 2,277 & 0.951 \\
\hline M+86 & $348 / 85$ & 1,387 & 1,025 & 0,703 & $282 / 77$ & $077 / 12$ & $168 / 05$ & 1,973 & 0,769 \\
\hline M193A & $155 / 22$ & 1,744 & 0,866 & 0,662 & $212 / 12$ & $118 / 18$ & $335 / 68$ & 2,634 & 3,276 \\
\hline M193B & $\$ 14 / 39$ & 1,708 & 0,832 & 0,704 & $030 / 05$ & $124 / 39$ & $294 / 51$ & 2,426 & 5,827 \\
\hline M206A & $160 / 62$ & 1,443 & 1,002 & 0,692 & $230 / 33$ & $102 / 44$ & $340 / 28$ & 2,085 & 0.983 \\
\hline M215 & $337 / 60$ & 1,779 & 0.963 & 0.584 & $042 / 36$ & $276 / 40$ & $157 / 30$ & 3,046 & 1,306 \\
\hline$F 198$ & $349 / 70$ & 1,724 & 1,385 & 0,507 & 077105 & $333 / 69$ & $169 / 21$ & 2,331 & 0,016 \\
\hline \multicolumn{10}{|c|}{ Média Harmônica } \\
\hline \multirow{2}{*}{ Amostra } & \multirow{2}{*}{ Plano $X Y$} & \multicolumn{3}{|c|}{ Valores dos eixos principais } & \multicolumn{3}{|c|}{ Atitudes dos eixos principais } & \multirow{2}{*}{$\mathrm{x} / \mathrm{z}$} & \multirow{2}{*}{ K } \\
\hline & & $\mathrm{x}$ & $Y$ & $z$ & $\mathrm{x}$ & $\mathrm{Y}$ & $z$ & & \\
\hline M051 & $317 / 65$ & 1,659 & 1,046 & 0,576 & $011 / 51$ & $241 / 28$ & $137 / 25$ & 2,880 & 0,719 \\
\hline M183 & $350 / 69$ & 1,483 & 1.004 & 0,671 & $056 / 47$ & $276 / 36$ & $157 / 30$ & 2,210 & 0.962 \\
\hline$M 486$ & $348 / 85$ & 1,392 & 1,021 & 0,704 & $284 / 78$ & $077 / 10$ & $168 / 05$ & 1.977 & 0,804 \\
\hline M193A & $153 / 22$ & 1,690 & 0.870 & 0,680 & $213 / 12$ & $119 / 19$ & $333 / 68$ & 2,485 & 3,372 \\
\hline M193B & $115 / 40$ & 1,670 & 0,834 & 0,718 & $031 / 05$ & $126 / 39$ & $295 / 50$ & 2,326 & 6,251 \\
\hline M206A & $160 / 62$ & 1,437 & 1,009 & 0,690 & $229 / 34$ & $100 / 43$ & $340 / 28$ & 2,083 & 0,914 \\
\hline M215 & $337 / 60$ & 1,699 & 0,964 & 0,611 & $041 / 36$ & $276 / 39$ & $157 / 30$ & 2,781 & 1,318 \\
\hline F198 & $349 / 69$ & 1,331 & 1.316 & 0,571 & $260 / 02$ & $354 / 69$ & $169 / 21$ & 2,331 & 0,009 \\
\hline
\end{tabular}

Tabela 8.2. Comparação entre os resultados tridimensionais obtidos pelos métodos OPF, R/l e média harmônica 

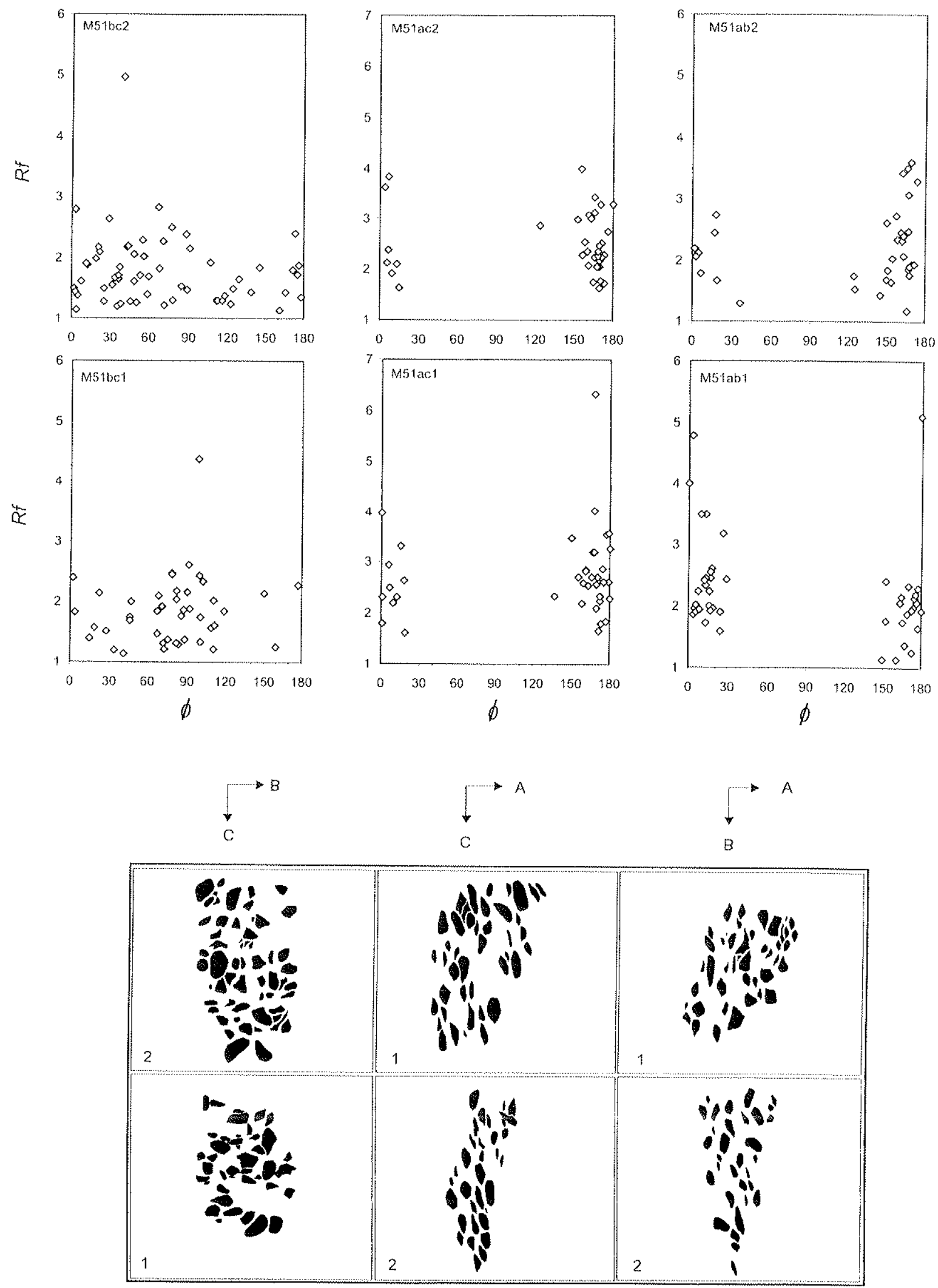

Figura 8.4. Gráficos Rfinal / Phi e respectivas sub-seções analisadas da amostra M51. 

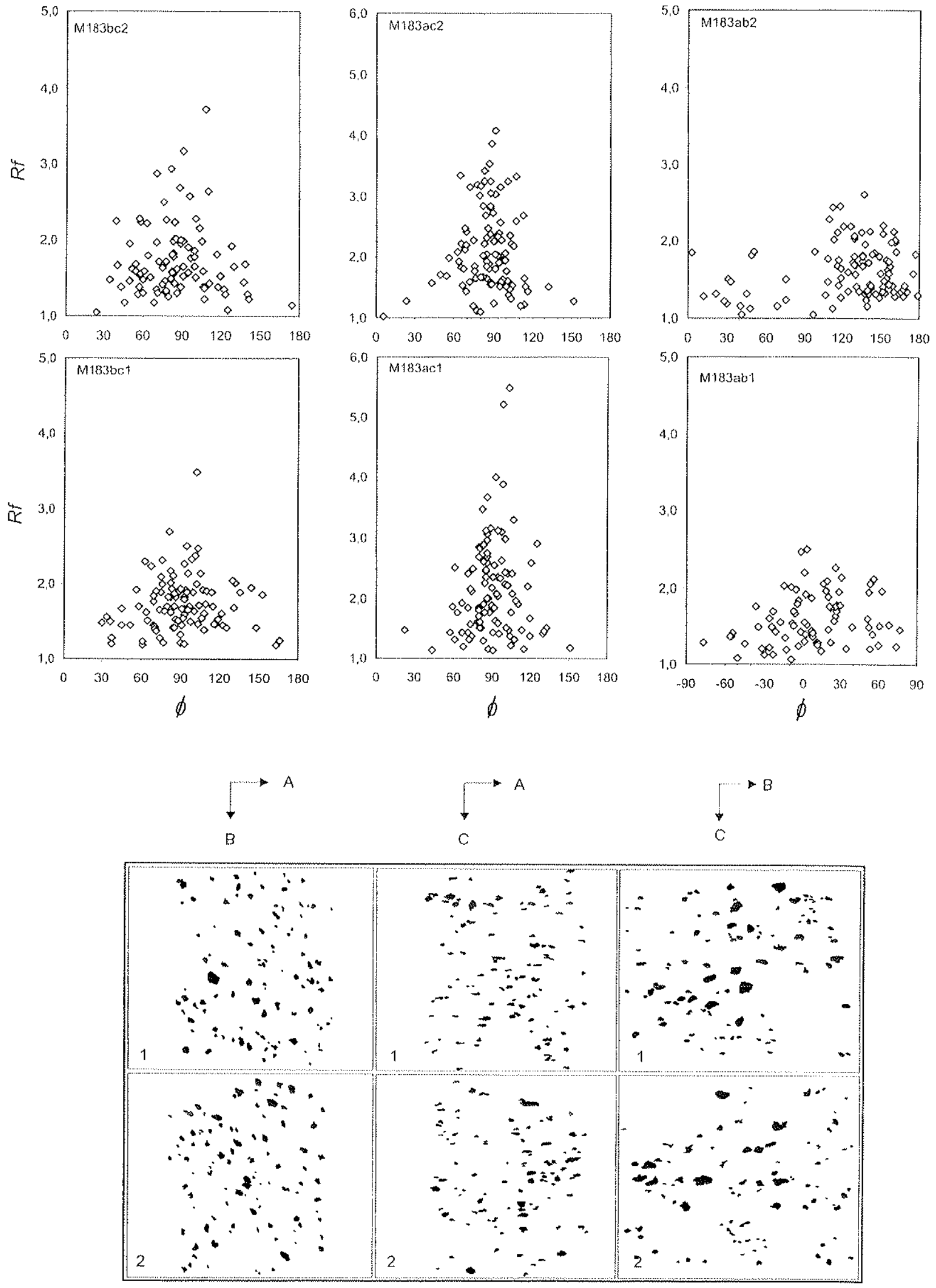

Figura 8.5. Gráficos Rfinak / Phi e respectivas sub-seções analisadas da amostra M183. 

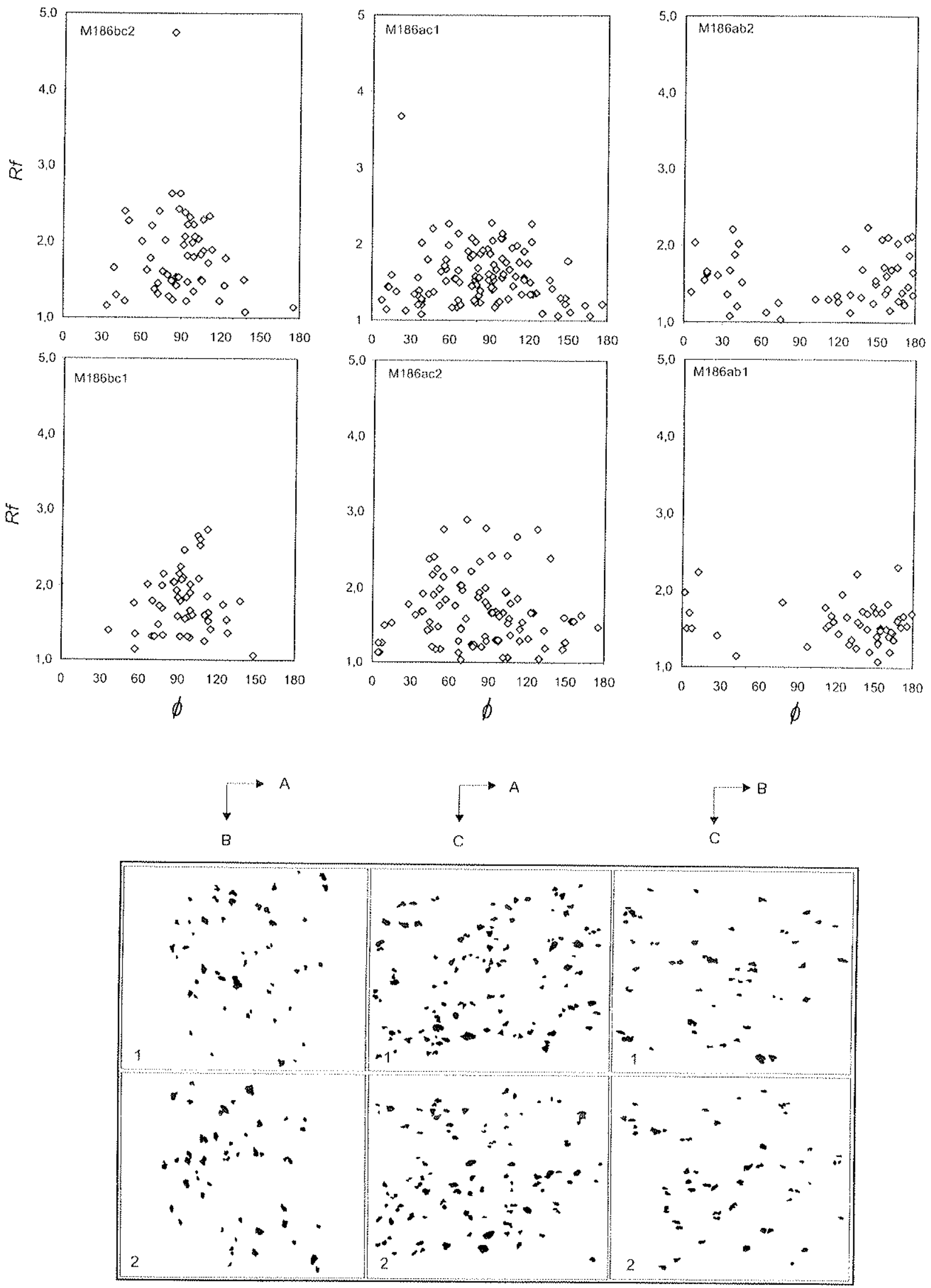

Figura 8.6. Gráficos Rinal / Phi e respectivas sub-seções analisadas da amostra M186. 

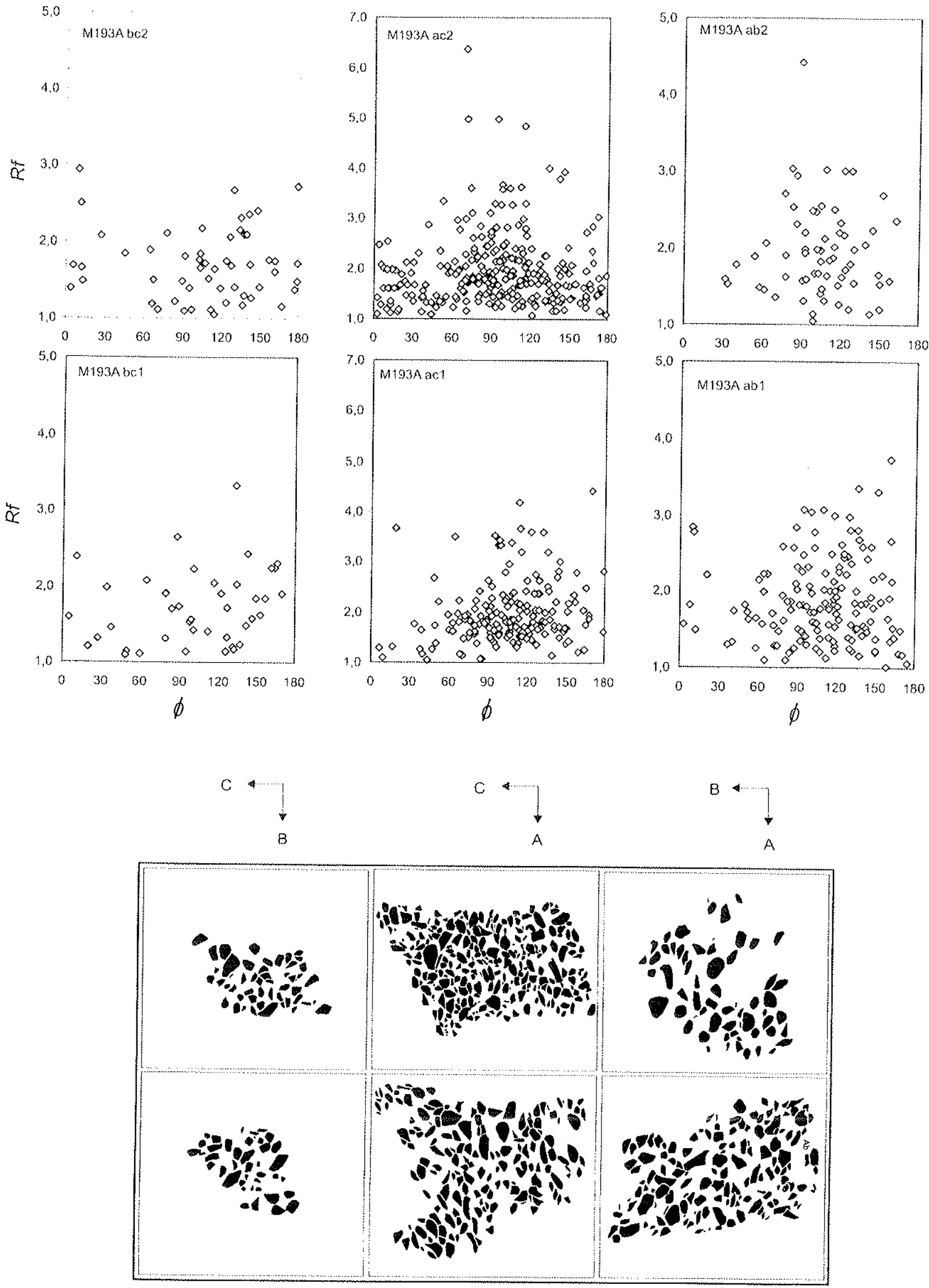

Figura 8.7. Gráficos Rtiral / Phi e respectivas sub-seções analisadas da amostra M193A. 

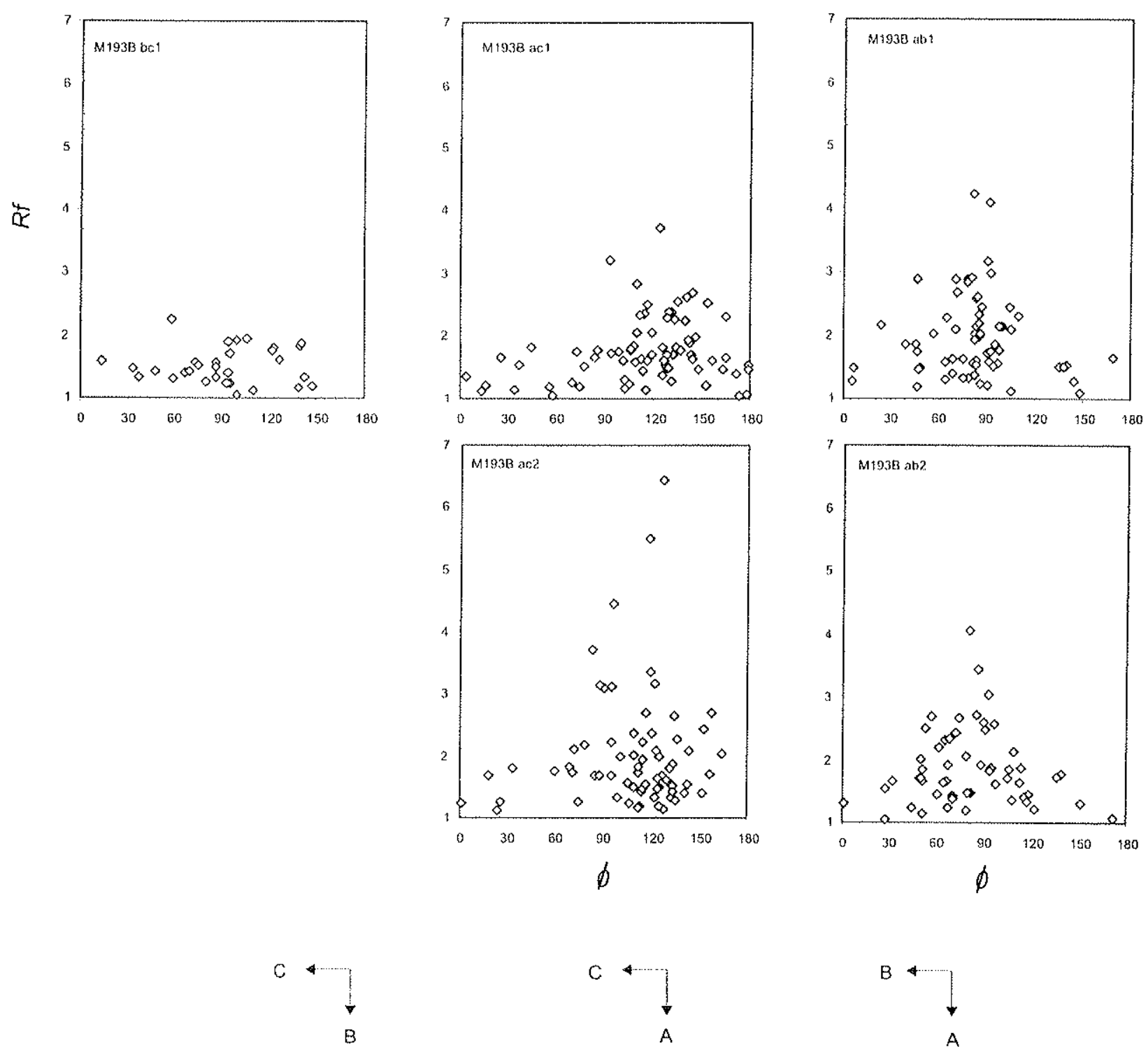

B

B

A

A

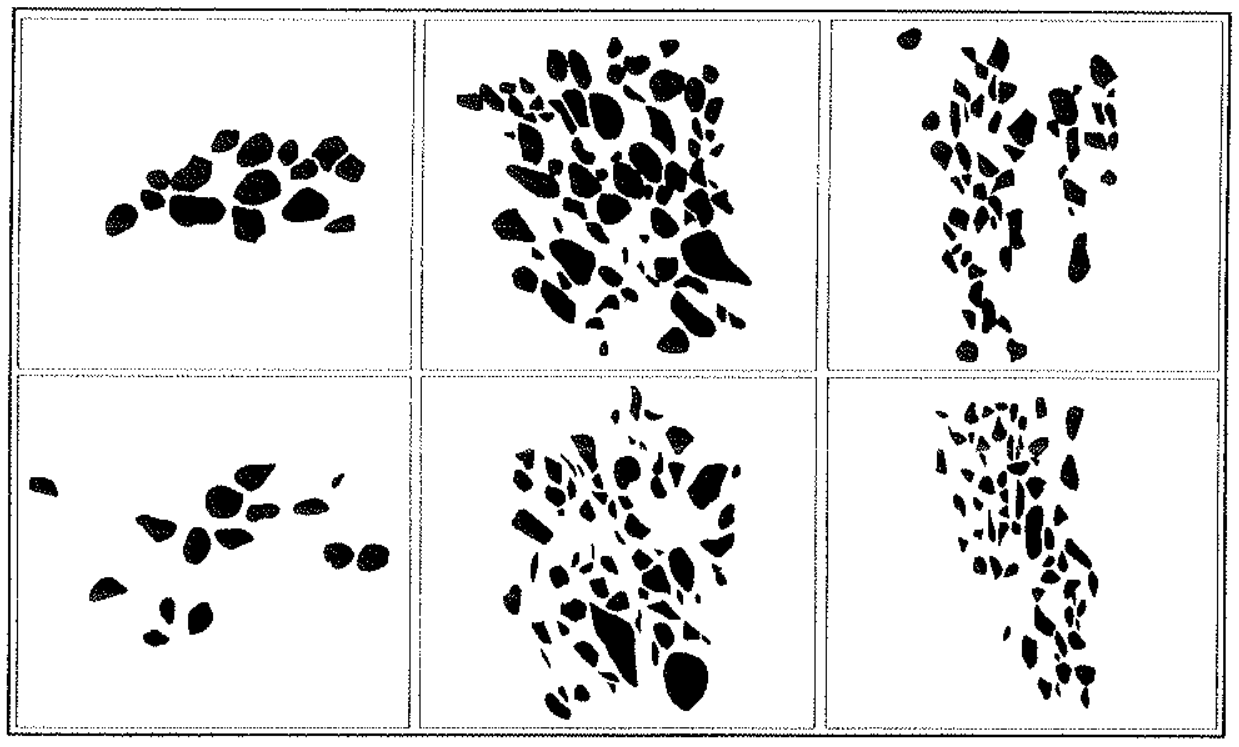

Figura 8.8. Gráficos Rfinal / Phi e respectivas sub-seções analisadas da amostra M193B 

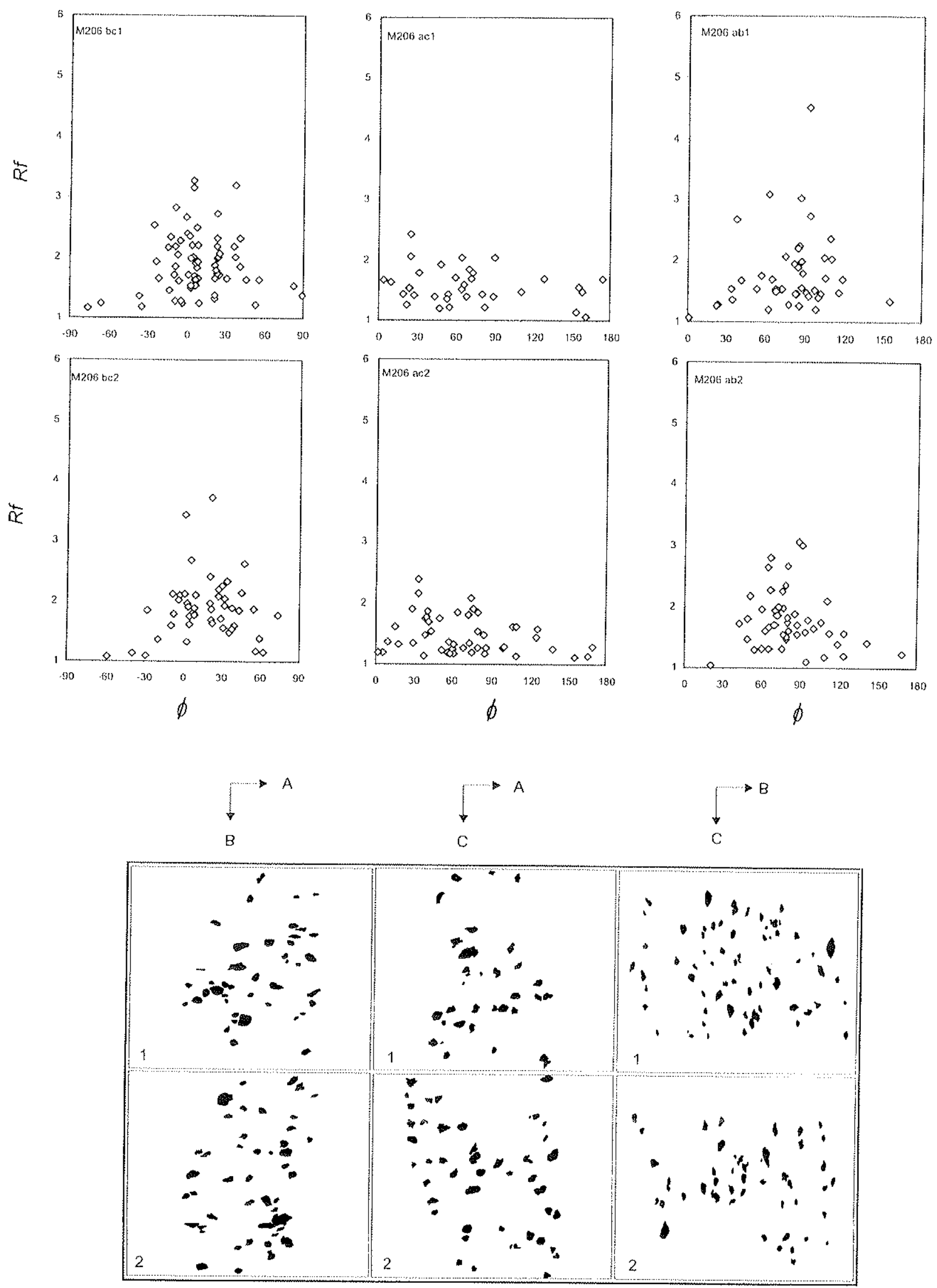

Figura 8.9. Gráficos Rfiral / Phi e respectivas sub-seções analisadas da amostra M206A. 

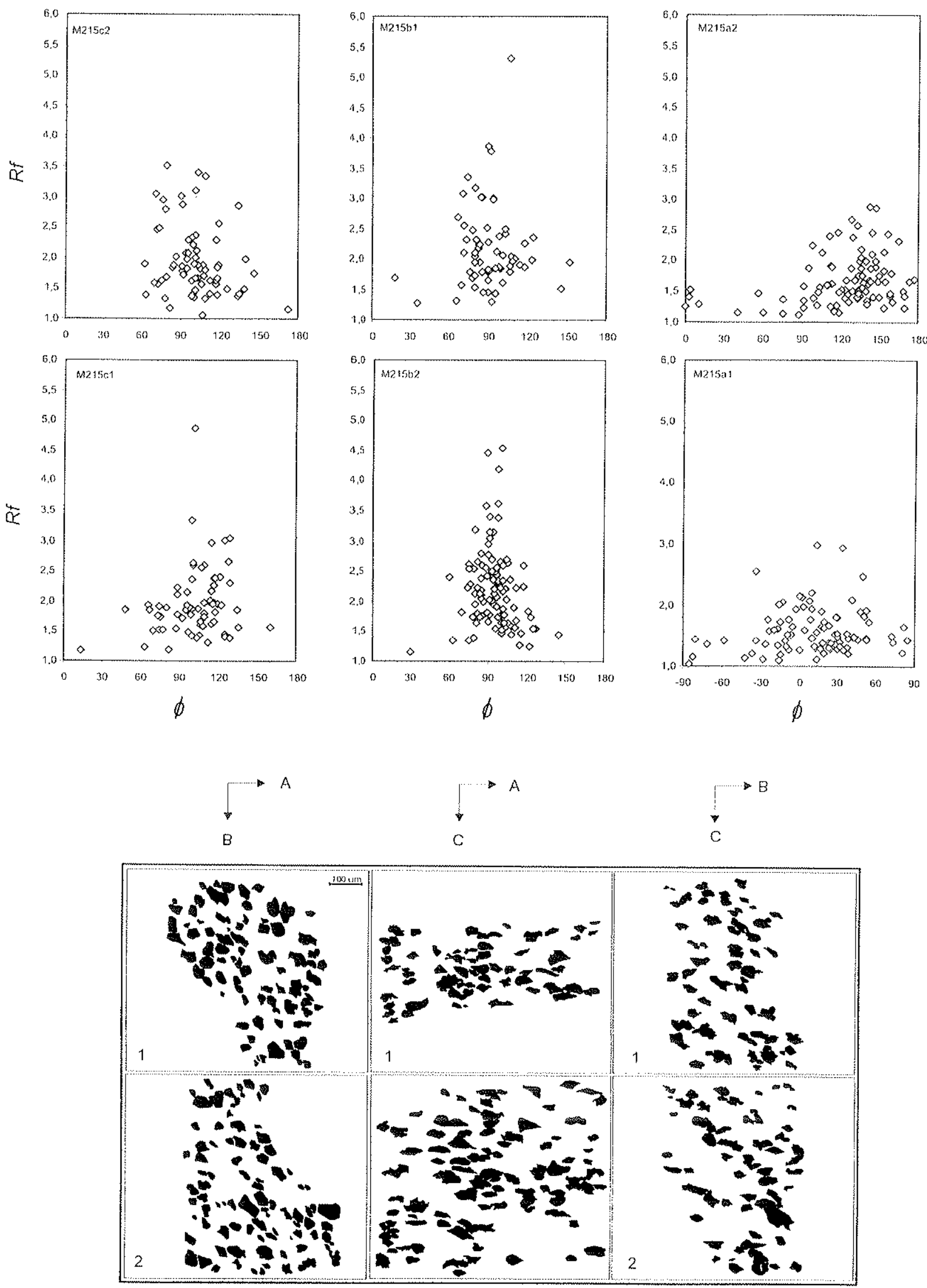

Figura 8.10. Gráficos Rinal/ Phi e respectivas sub-seçöes analisadas da amostra M215. 

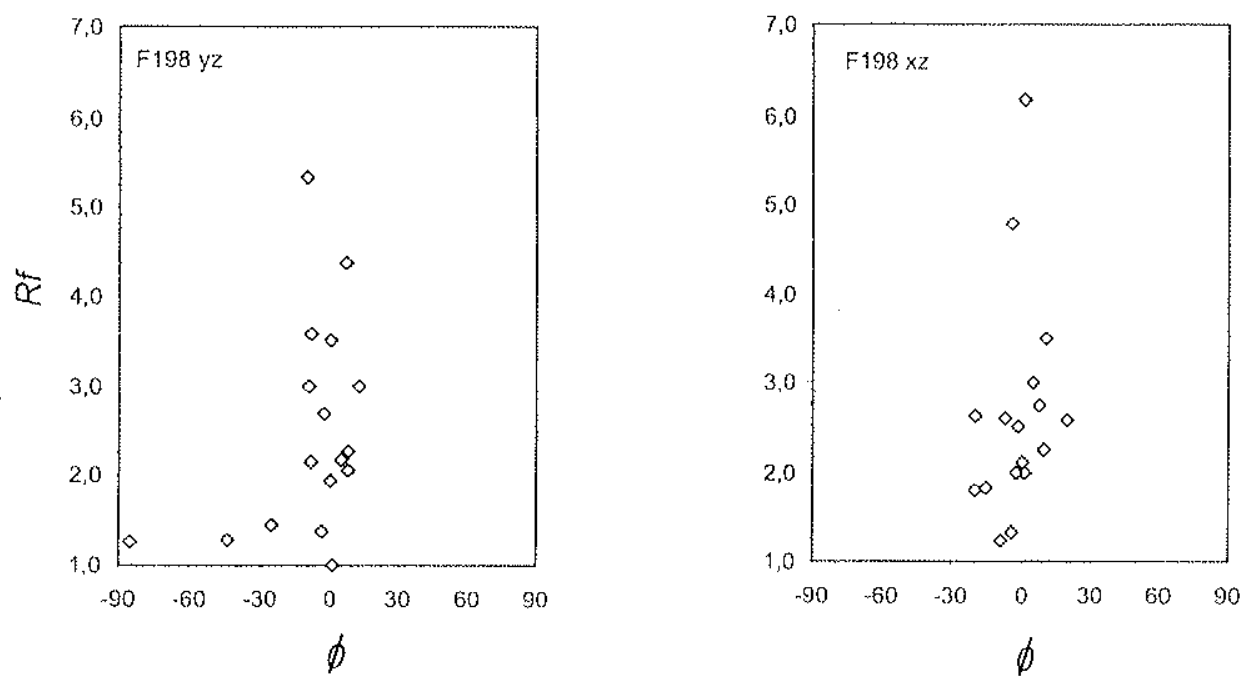

21
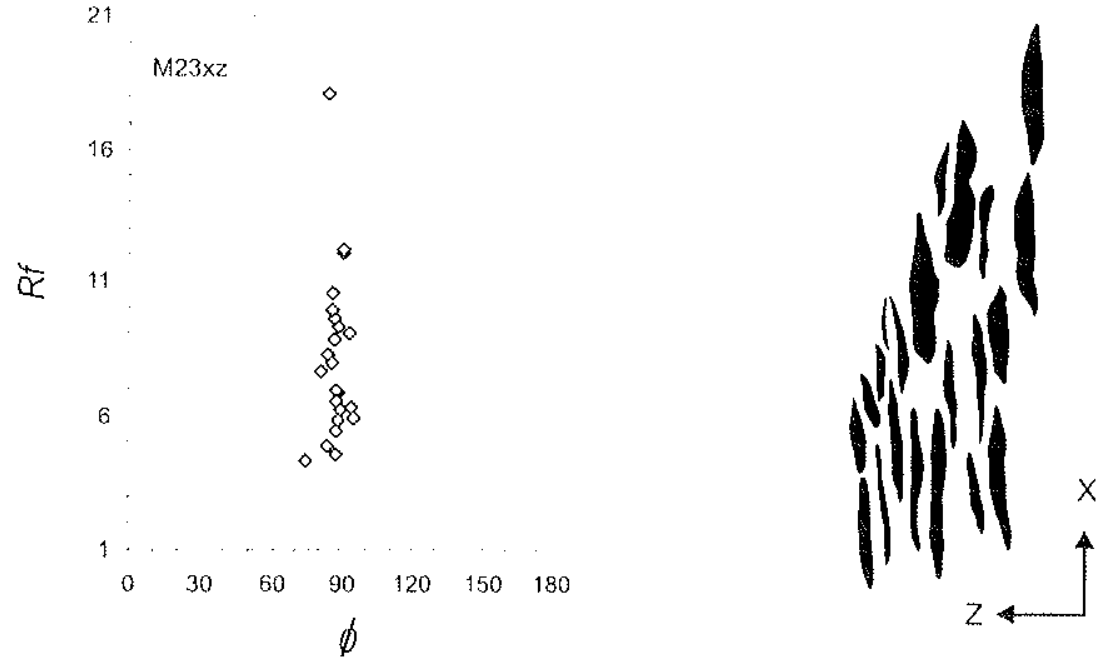

Figura 8.11. Gráficos Rfinał / Phi das amostras F198 e M23 e seção analisada da amostra M23. 


\subsubsection{Forma dos elipsóides}

Dos oito elipsóides de deformação obtidos, três se aproximam do tipo com $K=1$, sugerindo deformação plana (M183, M186 e M206A - Tabela 8.2, Fig. 8.12). Entre os elipsóides restantes, três caem no campo de estiramento aparente, sendo um levemente e dois fortemente prolatos (M215, M193A e M193B, respectivamente). Por fim, dois elipsóides caem no campo de achatamento aparente, sendo um levemente e outro fortemente oblato (M51 e F198, respectivamente).

O padrão fortemente assimétrico mostrado pelos gráficos $\mathrm{Rf} / \varnothing$ obtidos nas amostras de metaconglomerados M193A e M193B (Figs. 8.7-8.8), sugere que tais tramas prolatas são decorrentes da interação entre tramas sedimentares primárias e metamórficas. Portanto, podem não ser indicativas de diferentes domínios tectônicos. Adicionalmente devemos levar em conta que os resultados das duas amostras, representantes do mesmo ponto de amostragem, apresentaram diferenças consideráveis tanto na forma quanto na orientação dos elipsóides, indicando que estes são fortemente influenciados pelas caracteristicas estruturais anteriores à deformação.

O elipsóide $F 198$, fortemente oblato, foi obtido em afloramento localizado na zona de interferência entre a ZCR e a Falha da Figueira. Nesse caso, os gráficos Rf/ $\varnothing^{\prime}$ para os planos $X Z$ e $Y Z$ mostram padrões típicos de altas deformações (Fig. 8.11). A forma fortemente oblata pode ser decorrente da superposição entre as deformações da Falha da Figueira (caráter inverso) e da ZCR (transcorrente).

\subsubsection{Intensidade da deformação}

Os valores de elipsidade máxima $\left(R_{s} x z\right)$, situam-se entre 1,97 e 3,05 (Tabela 8.2), mostrando deformações intermediárias. Exceção a esses valores são observados em amostras coletadas na faixa de mais intensa deformação da $Z C R$, onde o valor de $R_{s} \times Z$ de 7,25 obtido na amostra M23 e a presença de ribbons de quartzo com razões de forma maiores que $20 / 1$ no plano $X Z$ da amostra $M 161 \mathrm{H}$ (Fig. 5.3D) indicam deformações altas a muito altas.

Os dados mostram que, de modo geral, nas proximidades com a ZCR e no bloco a sul desta a deformação é maior. Exceção a esse padrão é mostrado pelas amostras M193A e M193B, cujos elipsóides forneceram deformações relativamente altas, mas que, como discutido acima, esses devem ter forte influência de tramas sedimentares primárias.

Deve-se ressaltar que os dados de deformação estimados são menores que aqueles obtidos na mesma área por Campanha \& Sadowski (2002), que encontraram 
razões de deformação máxima de 8,93 em rochas do Bloco Rio das Pedras. Fiori (1997) apresentou dados de $R_{\mathrm{s}}$ entre 1,8 e 2,4 em conglomerados da Formação Camarinha deformados pela Zona de Cisalhamento Lancinha. Esses dados são mais baixos que aqueles obtidos tanto no trabalho de Campanha \& Sadowski (2002), quanto no presente trabalho.

\subsubsection{Orientação dos eixos principais}

Dos oito elipsóides obtidos, cinco apresentam eixos $Z$ com atitudes SSE subhorizontais (Fig. 8.13A), consistente com planos de máximo achatamento de direção NE e mergulhos fortes para NW. A trama da amostra M206A apresenta eixo $Z$ com baixo merguho para NW, coerente com planos de achatamento com fortes mergulhos para SE. Tal feição pode ser explicada pela proximidade do ponto de coleta dessa amostra com as falhas Ribeira e Figueira, já que a inversão na direção de mergulho das foliações é muito comum em zonas de cisalhamento transcorrentes de alto ângulo. Os dois elipsóides restantes apresentam os eixos $Z$ com altos caimentos para NW, indicando planos de achatamento com mergulhos baixos para SE. O fato destes elipsóides representarem as amostras de metaconglomerados M193A e M193B, corrobora com a hipótese de uma forte influência da trama sedimentar primária, como discutido anteriormente.

As orientações dos eixos $X$ apresentaram caimentos variados, baixos, moderados e altos na direção NE-SW (Fig. 8.13B). Observa-se que no bloco a norte da ZCR, predominam as lineações de ângulo alto a moderado (Fig. 8.14). Das amostras com eixo $X$ de baixo caimento, duas encontram-se bem próximas da ZCR (F198 e M23), e as outras duas são aquelas de metaconglomerados com forte influência da trama sedimentar (M193A e M193B), embora estas amostras se localizem próximas à Zona de Cisalhamento Piririca, sugerindo que esta é de caráter transcorrente. Essa distribuição foge do padrão observado por Campanha e Sadowski (2002) onde a maioria dos eixos $X$ apresentaram caimentos baixos, a não ser nas regiões de influência de zonas de cisalhamento inversas tais como as falhas da Figueira e Agudos Grandes.

A única amostra do bloco a sul da ZCR (M215), apresentou eixo $X$ com caimento moderado para NE, estando muito próximo das lineações de estiramento locais. 

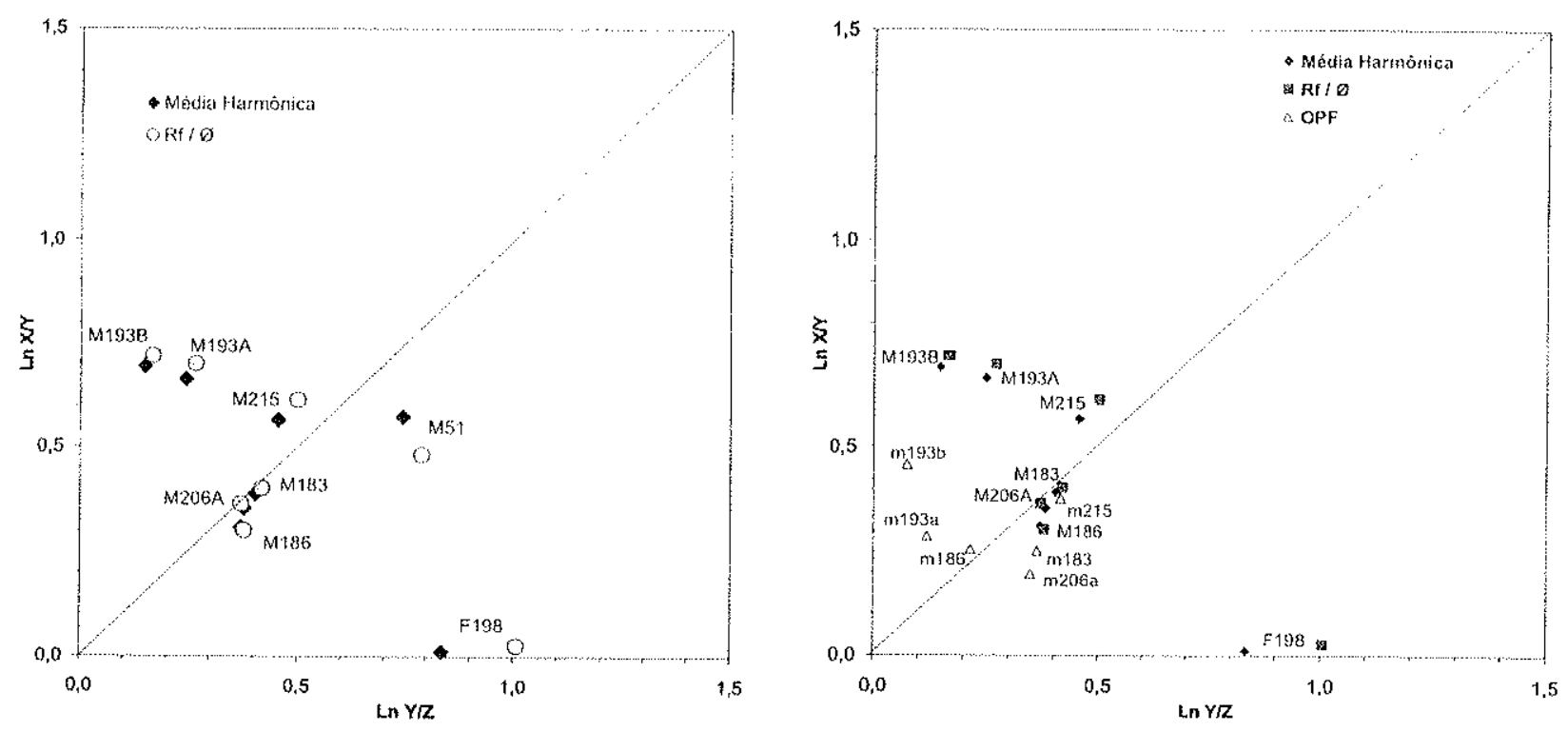

Figura 8.12. Diagramas de Flinn modificado (Ramsay \& Huber, 1983) com razões entre os valores principais de deformaçäo finita obtidos pelos três métodos.
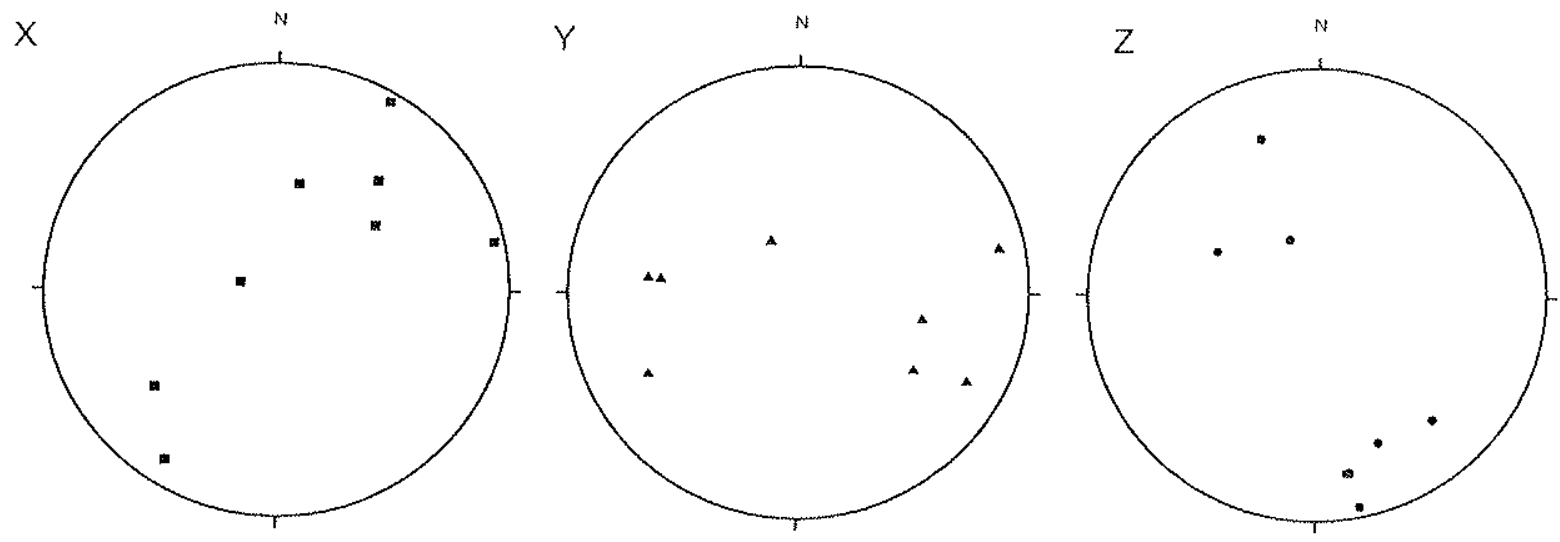

Figura 8.13. Orientaçäo dos eixos principais de deformação finita $(X, Y, Z)$ obtidas para as amostras analisadas. 


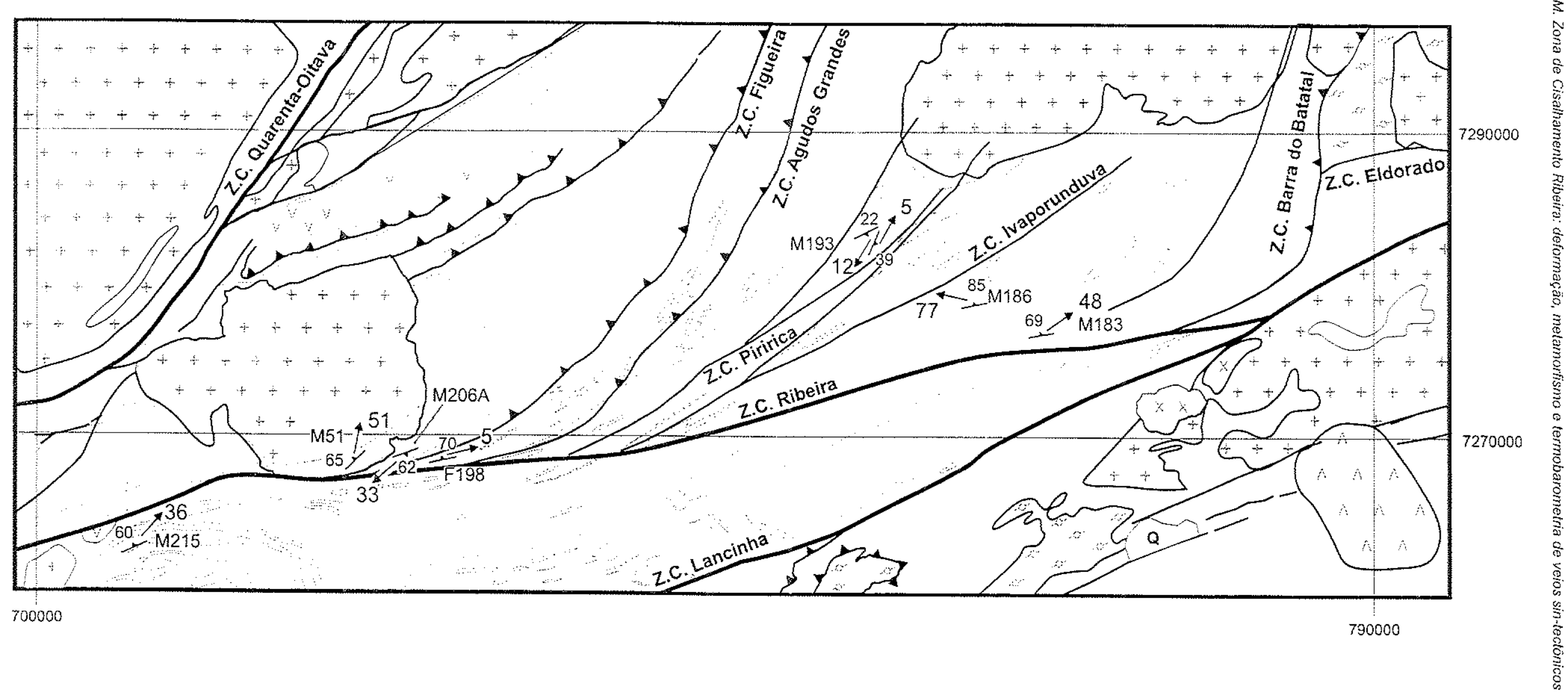

Figura 8.14. Atitudes do planos $X Y$ e dos eixos $X$ dos elipsóides de deformação finita. 


\section{TRAMAS DE EIXO-C DE QUARTZO}

\subsection{Introdução}

As tramas de orientação preferencial cristalográfica estão relacionadas aos mecanismos de deformação, à forma do elipsóide de deformação finita e ao padrão da deformação progressiva (coaxial ou não-coaxial) (Schmid \& Casey, 1986). No caso de deformações não-coaxiais, podem indicar o sentido de rotação. As tramas cristalográficas podem também fornecer informações sobre as condições metamórficas em que ocorreu a deformação, uma vez que os sistemas de deslizamentos ativados são governados pela temperatura, pressão de confinamento e quantidade de fluidos presentes no momento da deformação (Lister \& Dornsiepen, 1982).

Medidas de eixo-c de quartzo em oito seções delgadas de rochas de falha foram realizadas por intermédio de uma platina universal de quatro eixos. As amostras, orientadas no campo, foram cortadas no plano $X Z$ do elipsóide de deformação (plano perpendicular à foliação e paralelo à lineação de estiramento). Os eixos-c medidos foram lançados como linhas em redes estereográficas de igual área, semi-esfera inferior, e são representados por curvas de isofreqüência. Os dados lançados nos estereogramas têm como referência as direções principais do elipsóide de deformação finita $(X, Y, Z)$.

Descrições detalhadas dos procedimentos utilizados nas medições podem ser encontradas em vários trabalhos presentes na literatura geológica, dentre os quais podemos citar Turner \& Weiss (1963), Wahlstrom (1969) e Passchier \& Trow (1996).

\subsection{Petrografia das rochas de falha analisadas}

Diferentes tipos de tectonitos foram analisados, tais como granada-biotita-quartzomuscovita xistos miloníticos, quartzo-sericita-turmalina ultramilonitos, quartzo-sericita milonitos, biotita-sericita-quartzo milonitos e veios de quartzo cisalhados.

Os xistos miloníticos (amostras M14 e M214C) apresentam quartzo ribbons mono e policristalinos envoltos por leitos micáceos (Fig. 7.1), como sombras de pressão ao redor de granada e também na forma de grãos poligonizados formando texturas em mosaico de alto equilibrio (contatos retilineos a $\sim 120^{\circ}$ ). Na amostra M14 as foliações são representadas por pares $\mathrm{SC}_{1}$ (Fig. 7.1).

A textura dos ultramilonitos é definida por minerais recristalizados e estirados orientados em duas direções, formando estruturas SC. Correspondem a tipicos milonitos SC do tipo II de Lister \& Snoke (1984). A amostra M117 apresenta vênulas de quartzo poligonizado, onde foram realizadas as medidas. 
Nos milonitos, quartzo e sericita alternam-se em dominância. $\mathrm{Na}$ amostra M140 (proporção quartzo/sericita de $1 / 3$ ), o quartzo ocorre como porfiroclastos lenticulares formados internamente por grãos recristalizados com bordas serrilhadas e subgrãos. Tais porfiroclastos são envoltos pela matriz recristalizada de sericita, onde está presente pequena porcentagem de quartzo ribbons monocristalino, principalmente em leitos ultramiloniticos. $\mathrm{Na}$ amostra $\mathrm{M} 161 \mathrm{~F}$, onde a razão quartzo/micas é $4 / 1$, o quartzo ocorre como ribbons monocristalinos em meio a uma matriz muito fina de quartzo poligonizado, biotita e sericita, dispostos em duas foliações levemente obliquas que formam estruturas SC do tipo II de Lister \& Snoke (1984).

Os veios de quartzo são formados por quartzo ribbons monocristalinos intensamente estirados, envoltos por matriz de quartzo microcristalino poligonizado (amostras F42B, M023 e M161H).

\subsection{Descrição das tramas de eixo-c de quartzo}

Em todas amostras foram medidos eixos-c tanto de quartzo ribbons como de grãos recristalizados. Os resultados mostram que não ocorre variação das orientações nas diferentes gerações de quartzo.

As rochas de falha da ZCR apresentam cinco padrões principais de tramas cristalográficas:

(1) Caracterizado por concentrações máximas de eixo-c pontuais e simétricas nas posições intermediárias entre os eixos $X$ e $Z$ do elipsóide de deformação finita, sendo conectadas por subconcentrações ao redor do eixo $Y$ (M14 e M214C, Fig. 9.1). Esse padrão se aproxima de tramas em guirlandas cruzadas do tipo Il de Lister (1977). O ângulo de semi-abertura dos círculos minimos observados nas duas amostras varia de $33^{\circ}$ a $40^{\circ}$.

(2) Concentrações máximas de eixo-c em guirlandas de círculos mínimos centradas ao redor de $Z$ sendo conectadas por subconcentrações ao redor do eixo $Y$ do elipsóide de deformação finita (M117, Fig. 9.1). Corresponde ao padrão de guirlanda cruzada do tipo I de Lister (1977) quase completa. Também nesse caso o ângulo de semi-abertura dos círculos mínimos é de aproximadamente $40^{\circ}$. 

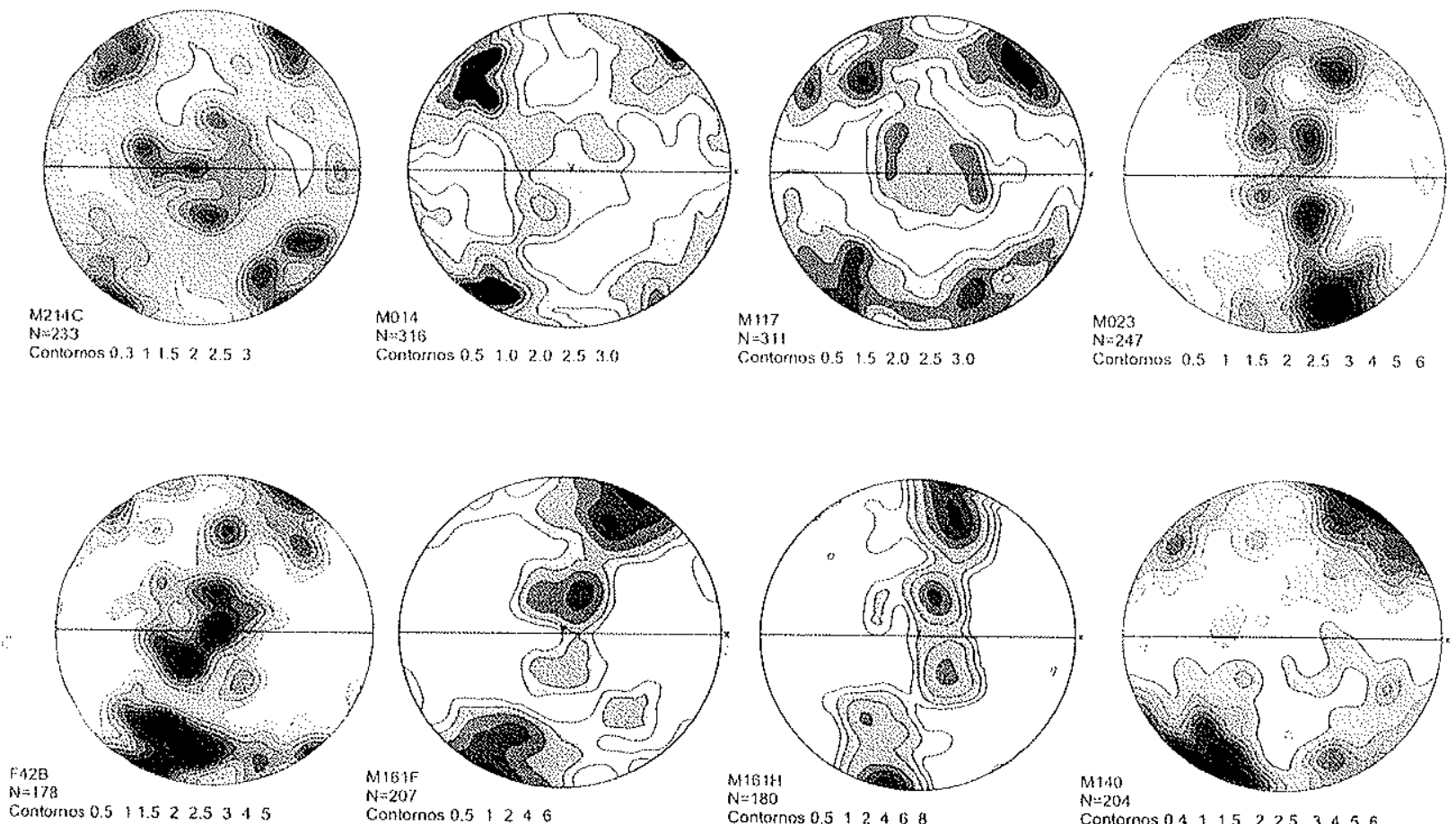

Figura 9.1. Tramas de eixo-c de quartzo de rochas de fatha associadas à Zona de Cisalhamento Ribeira. Projeção em recles de igual área, semi-esfera inferior M214C e M014 - granada-biotita-quartzo-muscovita xisto milonitico; M117 - vêntala recristalizada em citartzo-turmalina-sericita ultramilonito:
M140- quartzo-sericita milonito; M23, F42B, M161H - veios de çuartzo cisalhados: M161F (sericita)- quartzo milonilo.

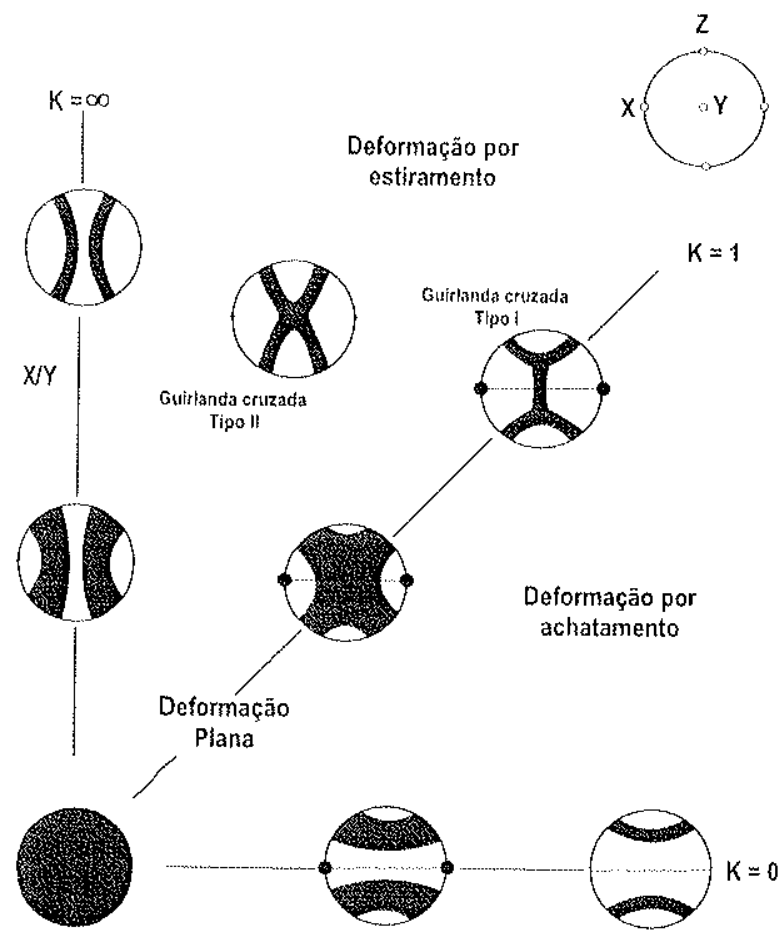

Figura 9.2. Principais padröes de eixo-c de quartzo esperados para deformaçäo coaxial dentro relacionadas com diferentes àreas do diagrama de Flinn. Adaptado de Schmid \& Ca sey (1986).
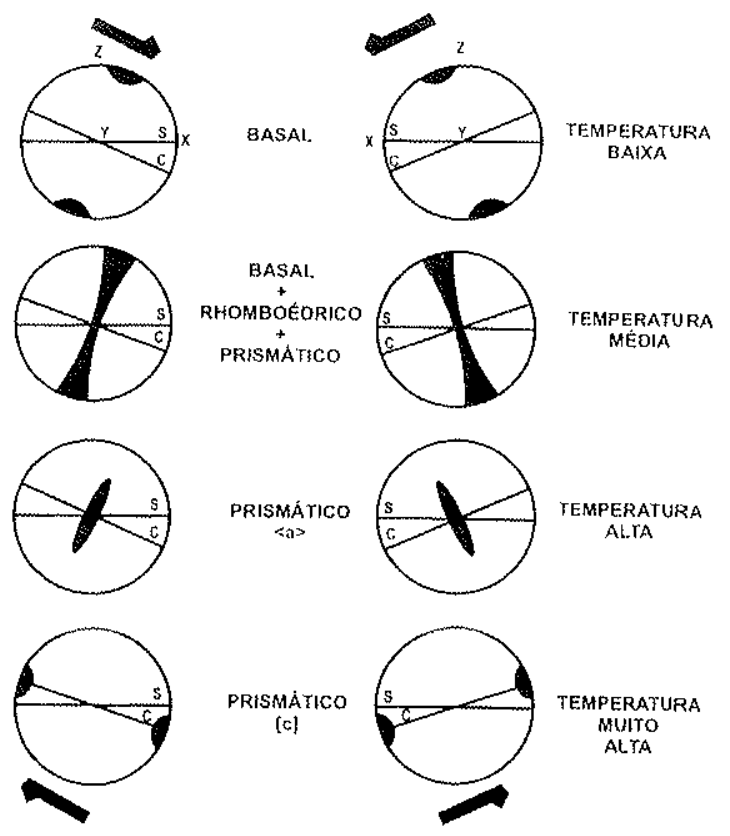

DESLIZAMENTO DOMINANTE

Figura 9.3. Relaçôes entre os padröes principais de eixo-c para defor mações nảo-coaxiais, os sistemas de deslizamento ativados e as faixas de temperaturas esperadas.. 
(3) Padrão intermediário entre guirlandas cruzadas do tipo I de Lister (1977) e guirlanda simples assimétrica (M23, Fig. 9.1). Nesse caso, apesar das concentrações principais de eixo-c distribuirem-se em uma guirlanda de círculo máximo orientada em ângulo de $70^{\circ}$ em relação à foliação e à lineação de estiramento, a presença de concentrações centradas ao redor de $Z$ sugerem também uma distribuição em círculos mínimos, tornando dificil a distinção entre os dois tipos de trama.

(4) Concentrações de eixo-c em guirlandas de círculo máximo representantes de planos de alto mergulho orientados em ângulos entre 65 e $80^{\circ}$ em relação ao traço da foliação e lineação de estiramento (eixo X) (M161F, M161H e F42B, Fig. 9.1). Corresponde ao típico padrão de guirlandas simples assimétricas.

(5) Concentrações pontuais e simétricas centradas ao redor de $Z$ (em posições de $\sim 60^{\circ}$ em relação ao eixo $\left.X\right)$, e pequena ocorrência de eixo-c nas posições intermediárias entre $Y$ e Z (M140, Fig. 9.1). Apesar das concentrações principais simétricas ao redor de $Z$, não se observa tendências de distribuição em guirlandas de círculo mínimo, fato que, aliado ao padrão das subconcentrações dos eixos-c, sugerem tramas em guirlandas cruzadas do tipo 11 incompletas. Maiores concentrações de eixo-C nos quadrantes NE e SW sugerem deformações nãocoaxiais.

\subsection{Discussão}

\subsubsection{Padrão da deformação progressiva}

Das oito amostras estudadas, três apresentaram padrões de eixo-c dispostos em guirlandas cruzadas simétricas, sugestivas de deformação coaxial (M14, M117, M214C Fig. 9.1). Extensivas modelagens numéricas presentes na bibliografia (e.g. Lister \& Willians, 1979; Lister \& Hobbs, 1980) possibilitam a interpretação cinemática dessas tramas. A trama de guirlandas cruzadas do tipo I, exemplificada pela amostra M117 (Fig. 9.1), pode ser correlacionada com tramas resultantes de deformação plana prevista pelo modelo B de Lister \& Hobbs (1980). Segundo Price (1985) a guirlanda de círculo mínimo pode ser ampla, porém, reconhecivel em baixas deformações e torna-se levemente mais distinta em altas deformações. Quanto melhor desenvolvida a guirlanda parcial sobre $Y$, maior o componente de deformação plana em relação ao de achatamento (Price, 1985).

As tramas em guirlandas cruzadas do tipo II observadas nas amostras M14 e M214C (Fig. 9.1), são indicativas de padrões de deformação diferentes. Tramas desse 
tipo podem ser correlacionadas com aquelas resultantes de deformação plana prevista pelo modelo C de Lister \& Hobbs (1980). No entanto, Schmid \& Casey (1986) ao analisarem diversos trabalhos presentes na literatura, concluiram que existem fortes evidências de que as tramas em guirlandas cruzadas do tipo Il são típicas de deformação por estiramento.

A ocorrência de tramas indicativas de deformação coaxial em rochas da Zona de Cisalhamento Ribeira não é facilmente explicável, uma vez que existem várias evidèncias do predominio de deformação rotacional.

Price (1985) afirma que deformações não-coaxiais fora de zonas de cisalhamento não são compelidas a cisalhamento simples e deformação plana e, consequentemente, padrões de tramas mais similares àqueles resultantes de deformação por estiramento ou achatamento são encontrados. Porém, as tramas cristalográficas simétricas apresentadas pelas amostras M14, M117 e M214C apresentam forte estiramento e intensa recristalização, necessitando de outra explicação.

Lister \& Willians (1979) simularam a sobreposição de deformação coaxial em rochas que haviam sido previamente submetidas a deformação não-coaxial e concluíram que as mudanças na cinemática da deformação podem modificar as tramas, complicando assim suas interpretações. No entanto, apesar da modificação, as tramas podem preservar a assimetria (Lister \& Willians, 1979).

As amostras restantes (F42B, M23, M140, M161F e M161H - Fig. 9.1) apresentam tramas tipicamente relacionadas com deformações não-coaxiais. Com exceção da amostra $M 140$, todas as outras apresentam padrões correlacionáveis com tramas previstas como resultado de cisalhamento simples (e.g. Lister \& Hobbs, 1980; Lister \& Willians, 1979).

Existe uma clara correlação entre o tipo de trama e a litologia e/ou domínio estrutural/metamórfico. As tramas em guirlandas cruzadas do tipo II foram observadas em xistos formados pela assembléia quartzo + muscovita + biotita + granada (M14 e $\mathrm{M} 214 \mathrm{C}$ ), ocorrentes no bloco a sul da Zona de Cisaihamento Ribeira, onde o grau metamórfico é mais alto. A estimativa da deformação finita realizada neste domínio estrutural (M215 - ver capitulo anterior), forneceu trama prolata com $K=1,3$. Esse resultado corrobora com as tramas cristalográficas indicativas de deformação por estiramento, conforme discutido anteriormente.

As tramas em guirlandas simples foram obtidas em amostras de veios de quartzo milonitizados (F42B, M23 e M161F) e biotita-muscovita-quartzo xisto milonítico com proporção entre quartzo e micas de 4/1 (M161F). Todas essas amostras foram coletadas nas faixas de mais intensa deformação da ZCR, de forma que, não se sabe se as tramas cristalográficas estão relacionadas com o dominio estrutural ou com o litotipo. Não existe 
um consenso sobre os efeitos das proporções relativas de outras fases minerais associadas ao quartzo na orientação dos eixos-c. Joy \& Saha (1998) estudaram amostras de quartzitos contendo de 2 a $35 \%$ de impurezas como muscovita e clorita e concluíram que essas não influenciavam nos padrōes de tramas de eixo-c. De qualquer forma, observamos que a amostra onde a quantidade de sericita excede a de quartzo (M140), foi aquela que apresentou o padrão de orientação cristalográfica mais divergente em relação às outras amostras, sugerindo que as tramas podem ser influenciadas quando a quantidade de micas é grande.

$\mathrm{Na}$ amostra M117 existem fortes indicios texturais de que os grãos de quartzo das vênulas, onde foram medidos os eixos-c, foram submetidos a recristalização estática (annealing), conforme discutido no item 5.3. Dessa forma, o padrão de orientação cristalográfica dessa amostra pode ter sido modificado. Tramas de eixo-c de quartzo modificadas por processos de annealing foram identificadas recentemente em amostras do Sistema de Cisalhamento Além Paraiba-Padua (Egydio-Silva et al., 2002). Os autores usaram como argumento de semelhante interpretação o fato de que as rochas estudadas (milonitos granulíticos), além de mostrarem evidências texturais de annealing, apresentaram tramas cristalográficas incompativeis com o grau metamórfico alto. Por outro lado, resultados de recristalização estática experimental em quartzitos apresentados por Heilbronner \& Tullis (2001 apud Egydio-Silva et al., 2002) mostraram que as tramas cristalográficas pré-existentes foram fortemente preservadas, embora o tamanho e a forma dos grão tenham sido intensamente modificados.

Como a recristalização estática nas vênulas da amostra M117 produziu apenas poligonização e um pequeno aumento no tamanho dos grãos, é mais provável que a trama cristalográfica anterior ao annealing tenha sido preservada.

\subsubsection{Sentido de rotação}

A assimetria externa das tramas de eixo-c representativas de deformações nãocoaxiais mostra sentido de rotação dominantemente destral (F42B, M140, M161F, $\mathrm{M} 161 \mathrm{H}$ ), compativel com outros indicadores cinemáticos (ver item 7). Apenas a trama M23 mostra uma assimetria sinistral, ainda que de certo modo vaga. 


\subsubsection{Sistemas de deslizamento ativados}

A orientação cristalográfica preferencial em agregados de quartzo é um indicador da temperatura da deformação, uma vez que o padrão da trama é controlado pela importância relativa de diferentes sistemas de deslizamento. O deslizamento basal <a> $\dot{e}$ dominante em baixas temperaturas e altas razões de deformação, produzindo tramas com eixos-c concentrados ao redor da direção $Z$ do elipsóide de deformação finita (Fig. 9.3). Com aumento da temperatura o sistema de deslizamento romboédrico <a> torna-se ativado, produzindo concentrações em orientações intermediárias entre os eixos $Y$ e $Z$ (Fig. 9.3). Finalmente, em altas temperaturas e baixas razões de deformação, o sistema de deslizamento prismático <a> pode atuar, resultando em concentrações máximas ao redor o eixo Y (e.g. Tullis et al., 1973; Lister \& Dornsiepen, 1982; Hobbs, 1985; Schmid \& Casei, 1986). Deformações em temperaturas muito altas podem resultar em concentrações de eixo-c na direção $X$ do elipsóide de deformação, como resultado do deslizamento prismático <c> (Blacic, 1975).

As rochas de falha da Zona de Cisalhamento Ribeira são caracterizadas, principalmente, por tramas com concentrações máximas posicionadas com baixos ângulos ao redor de $Z$, porém com máximos e submáximos em torno do eixo $Y$, ou intermediária entre os eixos $Y$ e $Z$ na maioria das amostras (Fig. 9.1). Essas concentrações indicam que na deformação do quartzo ocorreram ativações principais dos sistemas de deslizamento basal <a> e romboédrico <a>, porém com importantes contribuições do sistema prismático <a>. Somente a amostra M140 apresentou concentrações sugerindo unicamente deslizamento basal. Essa situação sugere temperaturas dominantemente médias na deformação (Fig. 9.3).

As paragêneses metamórficas corroboram com essa interpretação. Anfibolitos que ocorrem no mesmo ponto de coleta das amostras M161F e M161H apresentam a paragênese sin-milonítica hornblenda + andesina, indicando que a milonitização alcançou a fácies anfibolito, com temperaturas estimadas entre $550-600^{\circ} \mathrm{C}$ (ver capítulo 5). As amostras M14 e M214C foram metamorfizadas em condições de fácies xisto verde, zona da granada, com temperaturas mínimas estimadas entre 500 e $520^{\circ} \mathrm{C}$.

O ângulo de semi-abertura dos círculos mínimos observados nas tramas $\mathrm{M} 14$, $\mathrm{M} 117$ e $\mathrm{M} 214 \mathrm{C}$ varia entre $30^{\circ}$ e $40^{\circ}$. Mudanças nos valores desses ângulos foram correlacionados com variações na razão de deformação e na temperatura, em tramas produzidas experimentalmente (Tullis et al., 1973) e em quartzitos naturais (Hara et al., 1976). Ângulos menores são gerados em deformações de menores temperaturas e maiores razões de strain. Os modelos teóricos de Lister \& Hobbs (1980) indicam que estas diferenças em semi-ângulos de abertura devem-se a diferentes atividades nos 
sistemas de deslizamentos \pm romboédrico (círculos minimos a $\sim 30^{\circ}$ ) e os sistemas de deslizamento prismático e dipirâmidal-trigonal (círculos minimos a $\sim 40^{\circ}$ ). Esses sistemas podem ser considerados como mecanismos de reorientação competidores, predominando um ou outro dependendo das condições de temperatura e pressão. 


\section{INCLUSÕES FLUIDAS E ESTRUTURAS DE VEIOS DE QUARTZO}

Até a década de 70 considerava-se que as falhas tinham uma função passiva no emplacement de depósitos hidrotermais do nivel superior, agindo ou como condutos permeáveis para percolação de fluidos ou, em alguns casos, como barreiras impermeáveis que impediriam a migração destes. Sibson et al. (1975) foram os primeiros autores a proporem que os mecanismos de falhamento sísmico têm uma função chave no transporte intermitente de fluidos hidrotermais ao redor das zonas de cisalhamento, agindo como um mecanismo de bombeamento por meio do qual terremotos individuais são capazes de movimentar rapidamente grandes quantidades de fluidos de um ambiente da crosta para outro, onde serão depositados.

Dessa forma, os sistemas de veios associados com movimentações de falhas proporcionam uma boa evidência do envolvimento de fluidos durante os episódios de falhamento.

A pressão de fluidos elevada é um fator preponderante na indução da ruptura das rochas (fraturamento hidráulico). As condições de esforço necessárias para a formação de fraturas por extensão e por cisalhamento são expressadas graficamente na figura 10.1, a partir dos critérios de Navier-Coulomb (fraturas de cisalhamento) e de Griffith (fraturas extensionais) e, da representação dos estados de esforços pelo círculo de Mohr. Para ocorrer fraturas por extensão o círculo de Mohr deve tocar a envoltória de fraturamento rúptil no ponto onde $\tau=0 \mathrm{e} \sigma_{3}=T$, onde $T$ é a resistência à tração da rocha (Cosgrove, 1995). Como observado na figura 10.1, isso somente ocorre se o diâmetro do círculo de Mohr (esforço diferencial $\sigma_{1}-\sigma_{3}$ ) é pequeno, isto é < $4 T$ (Cosgrove, 1995).

Em regiões tectonicamente relaxadas da crosta, isto é, uma região onde a principal fonte de esforço é dada pela carga das rochas, ambos os esforços vertical e horizontal são compressionais, de forma que não poderia haver esforços por tração (Cosgrove, 1995). Na figura 10.2 são mostrados os estados de esforço para quatro diferentes rochas em profundidade (linhas cheias). Como os esforços principais são todos compressivos, nenhum desses estados de esforço podem causar fraturas extensionais. $O$ desenvolvimento da pressão de fluidos age de modo que se opõe ao esforço compressivo gerado pela carga de rochas e causa a redução do esforço efetivo ( $\sigma_{1}$ $\left.P_{\mathrm{H}_{2} \mathrm{O}}\right)$ e $\left(\sigma_{3}-P_{\mathrm{H}_{2} \mathrm{O}}\right)$. Assim, os círculos de Mohr são movidos para a direita por uma quantidade equivalente a $P_{H_{2} \mathrm{O}}$ e, desta forma, se o esforço diferencial é $<4 T$, o círculo de Mohr poderá tocar a envoltória de ruptura no ponto onde $\sigma_{3}=-T$ e $\tau=0$, causando 0 fraturamento (Fig. 10.2). Essas fraturas são chamadas de fraturas hidráulicas.

Em zonas de falhas ativas ocorre uma ciclicidade típica com o aumento da pressão de fluidos e tensões tectônicas que induzem a ruptura das rochas e, portanto, 
produzem permeabilidade ao longo da zona de falha. Essa permeabilidade momentânea induz a injeção dos fluidos e, desta forma, ocorre relaxamento das tensões tectônicas e da pressão de fluidos. Com a cicatrização da zona de falha, inicia-se um novo ciclo de carga de tensão e pressão de fluidos, até que as condições de ruptura novamente sejam alcançadas. Esse ciclo pode repetir-se inúmeras vezes ao longo da história geológica de uma falha.

Os sistemas de veios podem assim ser considerados como produtos fósseis exumados de atividade sísmica e oferecem a possibilidade de estudar os efeitos e a importância da sobrepressão de fluidos ao longo de falhas ativadas sismicamente. Considerados na escala de trabalho, os sistemas de veios podem também fornecer importantes informações sobre a circulação de fluidos em larga escala e sua redistribuição na crosta.

O estudo de inclusões fluidas tem se mostrado uma importante ferramenta na obtenção de informações sobre a composição e evolução de fluidos em sistemas metamórfico-hidrotermais ou magmático-hidrotermais, bem como auxiliado na definição da trajetória de pressão e temperatura de formação de veios sin-tectônicos. Somente no final da década de 80 e começo da década de 90 esse método começou a ser utilizado para resolução de problemas especificamente estruturais (e.g. Yonkee et. al., 1989; Boullier et. al., 1991; Foremam \& Dunne, 1991; Srivastava \& Engelder, 1991; Hodgkings \& Stewart, 1993), uma vez que, classicamente, era aplicado para análise de depósitos minerais.

O presente trabalho investiga amostras de veios de quartzo associados à faixas cisalhadas do Lineamento Ribeira. A boa exposição de sistemas de veios de quartzo com diferentes geometrias oferece uma oportunidade para o estudo de processos de falhamento e fluidos envolvidos. A ocorrência de inclusões fluidas seguramente primárias, além de inclusões pseudo-secundárias e secundárias, em trilhas, possibilita a determinação das condições de $\mathrm{P}$ e $\mathrm{T}$ de formação dos veios, bem como dos processos deformacionais posteriores aos seus selamentos. Ressalta-se que, classicamente na literatura, trabalhos de inclusões fluidas para resoluções de problemas estruturais foram realizados naquelas de origem secundária devido a destruição das inclusões primárias (Roedder, 1984; Xu, 1997). Como as inclusões primárias são muito abundantes nos veios da ZCR, temos uma oportunidade incomum de determinar as condições de cristalização destes veios. 


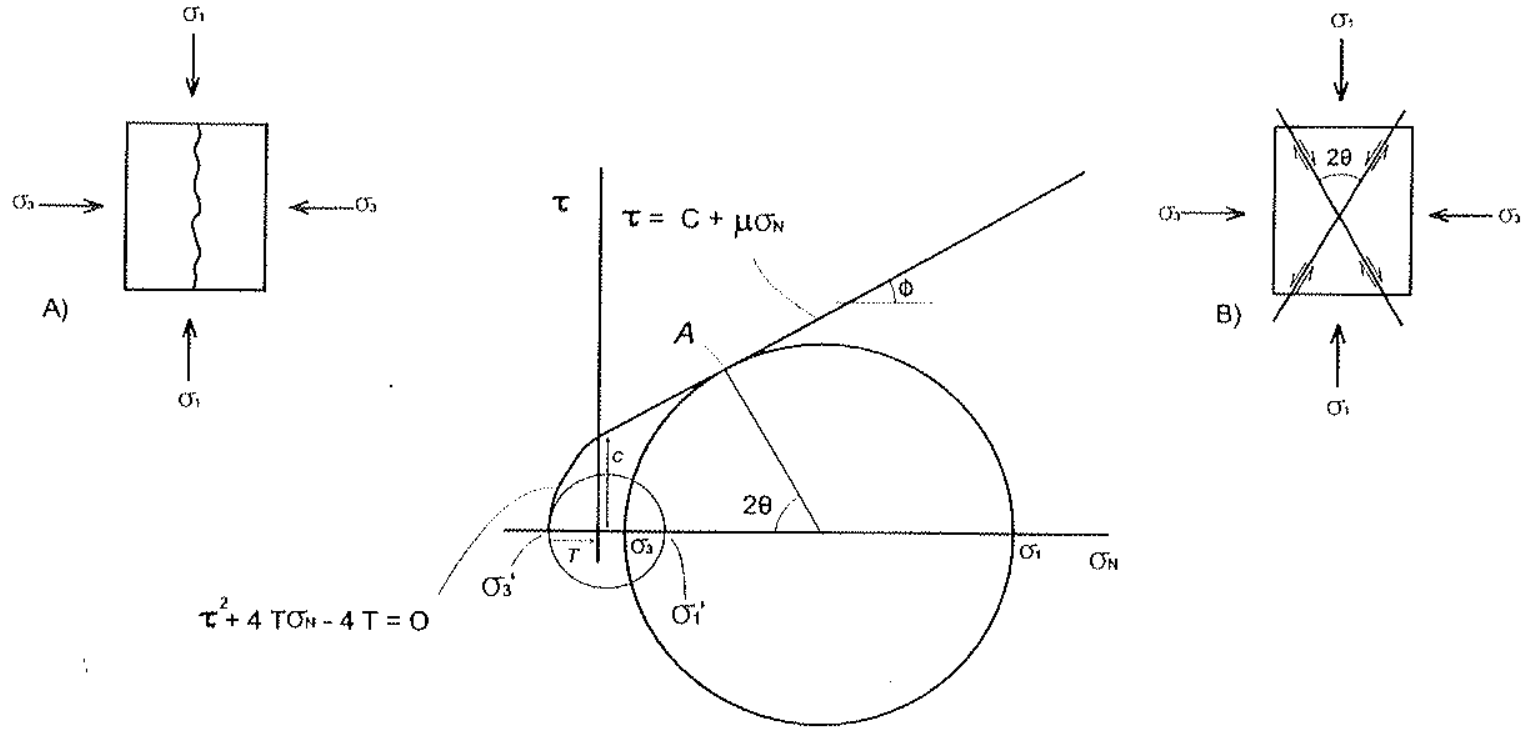

Figura 10.1. Expressäo gráfica dos dois critérios de fraturamento rúptil e do Circulo de Mohr representando os estados de esforço capazes de causar fraturas extensionais (A) e de cisalhamento (B). Adaptado de Cosgrove (1995).

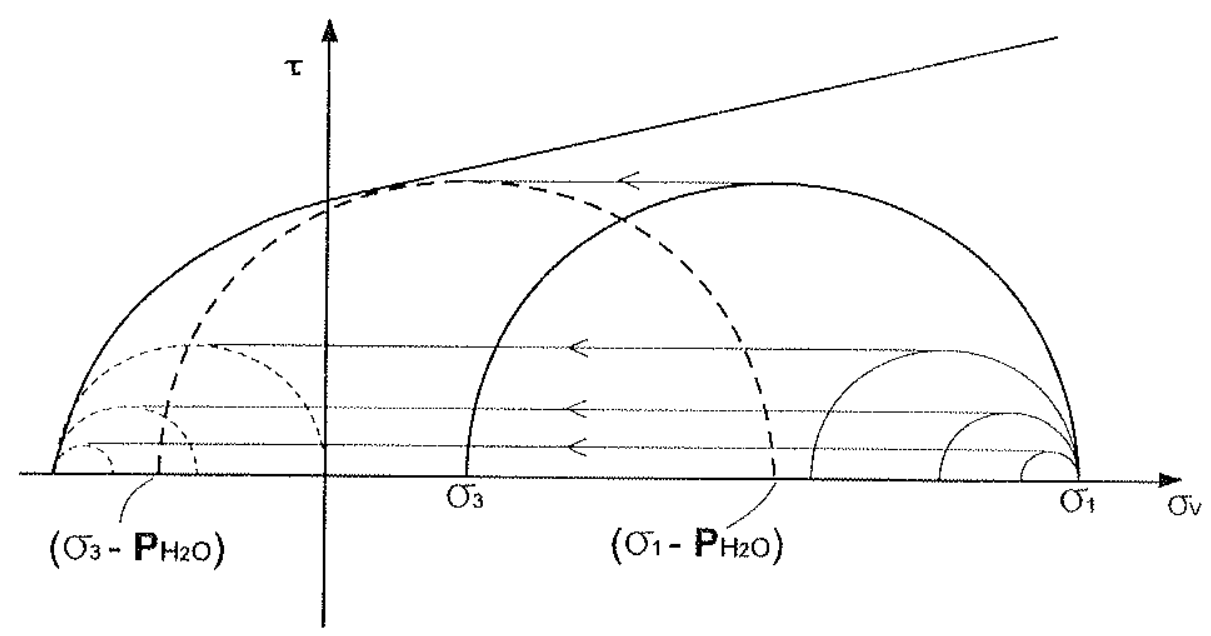

Figura 10.2. Círculo de Mohr com a representação de quatro estados de esforço que näo causaräo fraturamento (lirhas cheias). O efeito da pressão de fluidos è mover o estado de stress para a direita por uma quantidade $\mathrm{PH}_{2} \mathrm{O}$. Se o novo circulo (linhas pontilhadas) tocar a envoltória de Mohr ocorrerá o fraturamento hidráulico. Se este fraturamento se dará por cisalhamento ou extensão, depende do esforço diferencial. Adaptado de Cosgrove (1995). 


\subsection{Características Estruturais dos Veios de Quartzo}

Os sistemas de veios estão encaixados dominantemente em seqüências metassedimentares finas (filitos e xistos) com intercalações metabásicas (anfibolitos) subordinadas. Essas litologias estão inseridas no Subgrupo Ribeira e na Seqüência Serra das Andorinhas e encontram-se metamorfizadas, geralmente, na fácies xisto verde entre as zonas da clorita e da granada, apesar de ocorrerem assembléias de fácies anfibolito em alguns setores da ZCR (ver capitulo 5). A maioria dos veios de quartzo no Vale do Ribeira está concentrada ao longo das grandes zonas de cisalhamento que podem apresentar naturezas transcorrentes, reversas de alto ângulo e obliquas. A Zona de Cisalhamento Ribeira, objeto de nossos estudos, é tipicamente direcional.

Dois tipos principais de veios de quartzo podem ser distinguidos quanto a geometria: veios paralelos à foliação milonítica e veios extensionais discordantes. As características de cada tipo de veio são discutidas abaixo.

\subsubsection{Mesoestruturas}

Veios paralelos à foliação milonitica

Os veios paralelos à foliação ocorrem principalmente no interior da faixa milonitica, geralmente como feixes múltiplos. Apresentam espessuras variando de poucos centímetros a até um metro e extensões que podem chegar a centenas de metros, quando não interrompidas por feições de boudinagem. Suas formas podem ser tabulares ou sigmoidais (Fig. 10.3A). Cristais de quartzo leitoso dominam amplamente suas constituições, enquanto sulfetos ocorrem como traços. Estruturas primárias internas, tais como laminação e zonamentos mineralógicos, são muito raros ou inexistentes, dominando estruturas maciças. Feições deformacionais de geração concomitante ou posterior a formação dos veios são dominantes. Tais feições incluem fraturas, boudinagem, grãos fortemente estirados e intensa lineaçăo de estiramento nas paredes dos veios. As lineações de estiramento são quase invariavelmente subhorizontais e consistentes com movimentação transcorrente.

\section{Veios extensionais}

Os veios extensionais, mais raros, são encontrados nos arredores da faixa milonítica, porém, geralmente, fora das zonas de mais intensa deformação. Consistem de veios com quartzo leitoso, com espessuras variando entre 2 e $5 \mathrm{~cm}$. Suas formas podem ser lenticulares ou tabulares, alcançando, neste último caso, comprimentos de dezenas 
de metros. Apresentam direções em torno de N45W e mergulhos subverticais, sendo, portanto, discordantes da foliação milonítica (Fig. 10.3B). No campo parecem indeformados, visto que cortam a foliação e não foram boudinados, sugerindo estarem associados a etapas tardias de movimentação da zona de cisalhamento. Suas texturas são geralmente maciças, mas localmente ocorrem zonamentos reconhecidos por mudanças de cores e granulação entre os grãos que compõem o núcleo e a borda de certos veios.

Além dos dois tipos de veios principais, foram identificados veios boudinados com direção em torno de N25E. A presença de assimetrias indicativas de rotação em sentido horário, aliado à orientação desfavorável para aberturas, considerando-se um sistema transcorrente com o1 NW, sugere que esses veios devem ter sido gerados, inicialmente, na posição de extensão e, posteriormente, rotacionados pelo cisalhamento.

\subsubsection{Microestruturas}

Veios paralelos à foliação milonítica

Quatro tipos principais de texturas (P1, P2, P3, P4) foram reconhecidas nos veios encaixados na foliação milonítica.

- Tipo P1 - quando pouco deformados os veios podem apresentar estruturas maciças, onde os grãos de quartzo são subédricos e aproximadamente equidimensionais. Suas dimensões variam de 2 a $5 \mathrm{~mm}$. Feições de recristalização e deformação intracristalina são subordinadas, dominando uma extinção ondulante sutil. Nesses veios não são observados zonamentos nem grãos de diferentes gerações, o que pode indicar que se desenvolveram por um mecanismo de crescimento contínuo envolvendo um único estágio de dilatação e selamento. É comum a presença de concentrações de minerais opacos orientadas em faixas perpendiculares às paredes dos veios, que parecem representar antigas fraturas. Tais fraturas são seladas, $e$ os minerais opacos cristalizam-se em limites de grãos de quartzo e, subordinadamente, como inclusões. Essas feições sugerem que novo material foi adicionado e cristalizado nas fraturas.

- Tipo P2 - o segundo padrão de textura observada nos veios paralelos é caracterizada por fibras de quartzo fortemente orientadas. Os grãos apresentam razão de forma entre $3 / 1$ e $5 / 1$, onde as maiores dimensões chegam a $1 \mathrm{~cm}$. Internamente os cristais apresentam feições indicativas de deformação intracristalina, tais como bandas e lamelas de deformação que são sigmoidais e oblíquas à direção das fibras. Pequena 
porcentagem de grãos recristalizados ocorre dentro das bandas de deformação. Nas bordas destes veios ocorrem faixas alinhadas compostas por grãos de quartzo com granulações significantemente menores e com formas equidimensionais, que indicam mais de um evento de abertura e selamento e, portanto, ciclicidade dos processos que geraram os veios.

- Tipo P3 - o terceiro padrão de microestrutura consiste de zonas tabulares internas formadas por fibras de quartzo dispostas perpendicularmente às paredes. As fibras de quartzo apresentam bordas finas com quartzo recristalizado. Essas zonas tabulares são numerosas, preservam suas paredes bastante retilineas e alternam-se com faixas de grãos muito finos, recristalizados, definindo uma textura poligonizada. O contraste da deformação é muito acentuado, pois zonas praticamente indeformadas são alternadas com faixas completamente recristalizadas. As faixas poligonizadas apresentam orientações paralelas as paredes das zonas tabulares e perpendiculares a orientação das fibras de quartzo, indicando que as formas das fibras devem estar associadas aos processos de cristalização do veio e, não, relacionadas com deformações posteriores. Devem, portanto, representar texturas de preenchimento de espaços abertos reliquiares da época de formação destes veios. Provavelmente estas zonas tabulares pouco deformadas representam novo material adicionado ao veio previamente formado e deformado, indicando que a cristalização do veío foi cíclica.

- Tipo P4 - o último padrão de textura observado em veios intensamente deformados consiste de raros cristais de quartzo ribbons fortemente estirados envoltos por matriz muito fina composta por grãos recristalizados/recuperados definindo uma textura poligonizada. Intensa lineação de estiramento nas paredes ocorre associada. Feições da época da cristalização são ausentes. Nestes tipos de veios só foram encontradas inclusões fluidas secundárias sin-deformacionais, como será discutido abaixo.

\section{Veios extensionais}

Apesar de aparentemente indeformados quando observados em campo, os veios extensionais também apresentam feições deformacionais quando examinados ao microscópio petrográfico. Tais feições incluem quartzo ribbons (razão de forma 2/1 a 3/1), com extinção ondulante e bandas de deformação com faixas internas de grãos recristalizados. Essas faixas são obliquas à orientação dos ribbons e heterogeneamente desenvolvidas de grão para grão. Nestes veios minerais opacos incluidos em cristais de quartzo são abundantes e apresentam formas tabulares e cúbicas. Ocorrem também concentrações de carbonato microcristalino idiomórfico cristalizado em bordas de grãos. O grau de deformação é contrastante, visto a ocorrência de limites bruscos entre fibras 
de quartzo praticamente indeformadas e leitos quase completamente recristalizados. Nos leitos recristalizados, existem porfiroclastos de quartzo xenomórficos equidimensionais, com bordas serrilhadas, claramente diferentes das fibras presentes nas faixas menos deformadas.

Em vênulas extensionais ocorrem estruturas de crack-seal (quebra e selamento) formadas por um zonamento definido por um domínio externo, com cristais de quartzo muito finos, em contato com as paredes da rocha encaixante e um domínio interno onde ocorrem concentrações de quartzo subédrico mais grosso. Ambos domínios apresentam leves orientações preferenciais de forma perpendiculares às paredes das vênulas. $\mathrm{Na}$ amostra F200A, ocorrem abundantes cristais losangulares de minerais opacos na rocha encaixante. Esses cristais quando em contato com a vênula apresentam suas bordas corroídas, indicando desequilibrios termodinâmicos. Também ocorrem lascas da rocha milonítica embutidas na vênula.

Em suma, observa-se uma grande variedade no grau de deformação apresentado pelos veios, tanto paralelos quanto extensionais. A ocorrência de veios quase indeformados, veios completamente recristalizados e veios onde internamente existem faixas indeformadas truncadas por faixas intensamente recristalizadas é indicativa de que estágios de crescimento se alternaram com estágios de deformação. Ambos estágios representam partes de um ciclo repetido que levaram ao desenvolvimento dos sistemas de veios.

\subsection{Inclusões Fluidas - Método Analítico}

Foram preparadas 12 seções bipolidas, com espessuras entre 60 e $100 \mu \mathrm{m}$, de amostras de veios de quartzo, das quais sete foram selecionadas para estudos microtermométricos. Na figura 10.4 é apresentado o mapa de distribuição das amostras. Os dados microtermométricos foram obtidos em uma platina de resfriamento/ aquecimento CHAIXMECA, modelo MTM 85, que permite o resfriamento da amostra até $-180^{\circ} \mathrm{C}$ e aquecimento até $600^{\circ} \mathrm{C}$. Essa atividade foi realizada no Laboratório de Inclusões Fluidas do Instituto de Geociências da USP e contou com a orientação da Dra. Rosa Maria da Silveira Bello, responsável pelo laboratório. Foram realizadas análises qualitativas e semi-quantitativas por espectroscopia laser Raman em fases volateis de inclusões fluidas carbónicas e aquocarbônicas individuais, utilizando um equipamento Jobin Yvon modelo T64000, acoplado a um detector CCD resfriado $\operatorname{com} \mathrm{N}_{2}$ líquido, no Laboratório do Instituto de Geociências da Unicamp com orientação do Sr. Dailto Silva e 
do Prof. Dr. Roberto Perez Xavier; e também utilizando um Dilor Raman com um detector multicanal e a linha $514,53 \mathrm{~nm}$ de um laser Ar, no Laboratório de Óptica do Departamento de Física da UFMG, com orientação do Prof. Dr. Kazuo Fuzikawa.

A partir dos dados obtidos, as densidades, salinidades e isócoras dos fluidos foram determinadas utilizando-se equações de estado dos sistemas $\mathrm{H}_{2} \mathrm{O}-\mathrm{NaCl}, \mathrm{CO}_{2}-\mathrm{CH}_{4}$, e $\mathrm{CO}_{2}-\mathrm{CH}_{4}-\mathrm{H}_{2} \mathrm{O}-\mathrm{NaCl}$, presentes na literatura, com o auxilio do programa FLINCOR (Brown, 1989).

\subsection{Petrografia das Inclusões Fluidas}

Foram identificados quatro tipos principais de inclusões fluidas: inclusões carbônicas monofásicas, aquocarbônicas bifásicas e trifásicas, aquosas multifásicas (incluindo cristais de halita) ou bifásicas e inclusões constituidas por água e metano. Estes quatro tipos de inclusões apresentam diferentes modos de ocorrência e associações, dependendo do tipo de amostra (veio paralelo ou extensional), refletindo várias etapas de geração.

\subsubsection{Veios paralelos à foliação milonítica}

Nos veios paralelos à foliação milonítica foram identificados seis grupos de inclusões fluidas, de acordo com suas composições e modo de ocorrência, que foram classificados com as letras $A, B, C, D, E$ e .

O grupo $A$, presente em veios com texturas tipos $P 1$ e $P 2$, é formado pela associação de inclusões carbônicas e aquocarbônicas que ocorrem isoladas ou em arranjo aleatório no interior dos cristais, sugerindo naturezas primárias (Fig. 10.5A). Essas inclusões são as mais abundantes nos cristais menos deformados, em relação aos outros grupos de inclusões fluidas. Ambos tipos de inclusões apresentam-se com formas de cristais negativos geralmente com contornos arredondados, e dimensões variando de 3 a $15 \mu \mathrm{m}$.

As inclusões aquocarbônicas desse grupo são bifásicas à temperatura ambiente $\left(\mathrm{H}_{2} \mathrm{O}_{(1)}+\mathrm{CO}_{2}(1)\right.$ ou (v) $)$, apresentam grau de preenchimento variando de 5 a 90 (grau de preenchimento $=V_{\text {liq }} / V_{\text {liq }}+V_{\text {vapor ou gás }}$ ) e sua associação com as inclusões monofásicas carbônicas é uma primeira evidência de aprisionamento heterogêneo de fluidos.

O grupo B (Fig. 10.5B), ocorrente nos mesmos veios das inclusões do grupo $A_{1}$ é formado por inclusões multifásicas aquosas com sólidos de saturação incluindo halita, além de outros minerais não identificados. Apresentam graus de preenchimento aproximadamente constantes ao redor de 90 e morfologias variadas (poligonais, 
vermiformes e irregulares). Suas dimensões variam de 3 a $10 \mu \mathrm{m}$. O modo de ocorrência é bastante variado, predominando as inclusões pseudo-secundárias e secundárias aprisionadas em trithas intergranulares e transgranulares, respectivamente. Localmente ocorrem inclusões em arranjo aleatório ou isoladas, sugerindo naturezas primárias.

Uma importante característica observada em uma das amostras (F45), é que em alguns cristais de quartzo, as inclusões do grupo $A$ predominam $e$ as do grupo $B$ apresentam naturezas pseudo-secundárias e secundárias. Em outros cristais, principalmente os mais deformados, as inclusões do grupo B são muito abundantes, apresentam naturezas pseudo-secundárias e primárias, sendo raras as inclusões do grupo A. Como as inclusões do grupo A são sempre primárias, a hipótese mais provável é a de que elas teriam sido destruidas nos grãos mais deformados e as inclusões do grupo B estariam associadas com a deformação. No entanto, na amostra F254, na qual foram identificados os mesmos fluidos supradescritos, observa-se que as inclusões dos grupos A e B podem ocorrer localmente associadas, em arranjos aleatórios, independente do grau de deformação do cristal hospedeiro, sugerindo um aprisionamento cogenético. Duas hipóteses podem ser levantadas para explicar essa situação: 1) os fluidos dos grupos $A$ e $B$ foram separados a partir de um fluido originalmente homogêneo; 2) o fluido $B$ é relativamente tardio, mas localmente se misturou parcialmente com o fluido A. Pelo modo de ocorrência em geral, a segunda hipótese torna-se mais provável e esta é corroborada pelos dados microtermométricos, conforme será discutido posteriormente.

O grupo $\mathrm{C}$, presente nos veios com texturas do tipo $\mathrm{P} 1$, é constituido por inclusões carbônicas, aquocarbônicas e aquosas bifásicas aprisionadas associadamente em trilhas transgranulares (inclusões secundárias). As inclusões carbônicas (Fig. 10.5C) são monofásicas, apresentam formas ovaladas e dimensões variando de 2 a $8 \mu \mathrm{m}$. As inclusões aquosas associadas apresentam graus de preenchimento constantes (ao redor de 90) e dimensões entre 3 e $7 \mu \mathrm{m}$. Apesar de rarissimas, as inclusões aquocarbônicas apresentam graus de preenchimento muito variados. A ocorrência associada dos três tipos de inclusões em trilhas individuais indica que o aprisionamento foi heterogêneo.

grupo $D$, presente somente nos veios com texturas tipo P3, é formado por inclusões constituidas por água e metano, identificadas em apenas uma amostra. Estas ocorrem associadas com inclusões essencialmente aquosas que apresentaram 0 fenômeno do duplo congelamento, sempre em agrupamentos aleatórios no interior dos grãos (primárias). Ressalta-se que, além da diferença na composição das inclusões fluidas, o veio hospedeiro foi o único do tipo paralelo que apresentou texturas de crackseal, incluindo zonas tabulares com fibras de quartzo desenvolvidas em orientação perpendicular às paredes do veio truncando faixas mais antigas deformadas. Desse modo, é muito evidente que trata-se de um tipo de veio diferente do padrão geral 
identificado, além de confirmar as diferentes etapas de formação de veios sugerida pelas microestruturas.

$O$ grupo $E$ é formado por inclusões aquosas bifásicas secundárias que ocorrem em trilhas transgranulares tardias (Fig, 10.5D). Estão presentes nos veios com texturas tipo P1 e P2. Apesar de diferentes orientações das trilhas e diferentes composições, todas inclusöes são semelhantes quanto ao grau de preenchimento (ao redor de 90), morfologias (cristais negativos, vermiformes, irregulares), e dimensões (ao redor de 3-10 $\mu \mathrm{m})$

Em duas amostras representantes de veios intensamente deformados (texturas tipo P4), ocorrem somente inclusões carbônicas monofásicas (grupo F). As amostras caracterizam-se pela presença de raros porfiroclastos de quartzo disposto em ribbons em meio a uma matriz com quartzo poligonizado (grãos neoformados), como pode ser observado na figura 10.5F. Nos porfiroclastos as inclusões do grupo F ocorrem como trilhas transgranulares paralelas ou perpendiculares ao estiramento dos cristais. Nos grãos neoformados as inclusões ocorrem em grupos ou isoladas no interior dos cristais. Também ocorrem inclusões em junções triplice de subgrãos. Todas essas evidências indicam que as inclusões carbônicas do grupo $F$ estão geneticamente relacionadas com a milonitização do veio hospedeiro. Adicionalmente, os porfiroclastos de quartzo apresentam-se muito limpidos, com ausência de inclusões fluidas primárias, o que sugere que estas foram destruídas pela forte deformação dúctil.

\subsubsection{Veios extensionais}

Nesses veios foram identificados dois grupos de inclusões fluidas.

O grupo 1 é formado pela associação entre inclusões carbônicas e aquocarbônicas. Ocorrem em arranjos aleatórios, como inclusões isoladas no interior dos grãos e também como alinhamentos (inclusões pseudo-secundárias). Ambos tipos de inclusões apresentam formas de cristais negativos e dimensões variando de 3 a $15 \mu \mathrm{m}$. As inclusões aquocarbônicas são bifásicas a trifásicas à temperatura ambiente $\left(\mathrm{H}_{2} \mathrm{O}+\right.$

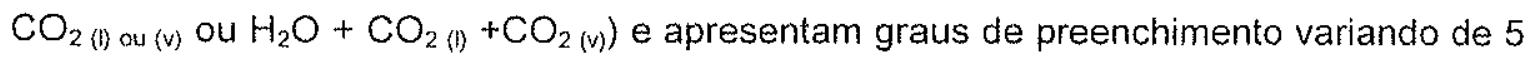
a 90. De forma semelhante aos fluidos do grupo $A$ dos veios paralelos, a coexistência dos fluidos do grupo 1 indica que o aprisionamento foi heterogêneo.

O grupo 2 consiste de inclusões aquosas bifásicas que ocorrem em faixas alinhadas no interior dos cristais. Deve-se ressaltar que apesar do alinhamento, essas faixas não representam trithas planares. Essa situação pode indicar que as inclusões do grupo 2 sucedem, imediatamente, as do grupo 1. Essas inclusões possuem dimensões 
entre 5 e $10 \mu \mathrm{m}$, formas irregulares e de cristais negativos e graus de preenchimento aproximadamente constantes, com valores ao redor de 90 .

\subsection{Microtermometria}

\subsubsection{Veios paralelos à foliação milonitica}

\section{Grupo A}

A fusão do $\mathrm{CO}_{2}$ nas inclusões do grupo $A$ (carbônicas e aquocarbônicas) ocorre entre $-64,2$ e $-58,4^{\circ} \mathrm{C}$ (Fig. 10.6A). Esses dados mostram a presença de importantes quantidades de outro componente volátil associado, visto que o ponto de fusão do $\mathrm{CO}_{2}$ puro ocorre em $-56,6^{\circ} \mathrm{C}$. A homogeneização do $\mathrm{CO}_{2}$ nas inclusões carbônicas ocorre invariavelmente para o estado liquido, principalmente entre $-4,5$ e $17,5^{\circ} \mathrm{C}$ (Fig. 10.6B), indicando densidades relativamente contrastantes $\left(0,92\right.$ e $\left.1,00 \mathrm{~g} / \mathrm{cm}^{3}\right)$ desse componente. As inclusões aquocarbônicas apresentam um comportamento mais complexo da homogeneização do $\mathrm{CO}_{2}$, que ocorre para os estados líquido, gás e crítico, dependendo da região analisada em cada amostra (Fig. 10.6B). Existem campos onde a homogeneização ocorre para o estado líquido em temperaturas aproximadamente constantes, independente do grau de preenchimento e campos onde a homogeneização ocorre para o estado gasoso nas mesmas faixas de temperatura. Essa situação indica densidades de $\mathrm{CO}_{2}$ amplamente contrastantes. Os valores estimados variam entre $0,11 \mathrm{e}$ $0,95 \mathrm{~g} / \mathrm{cm}^{3}$. As temperaturas de dissociação de clatratos nas inclusões aquocarbônicas desse grupo variam de -6 a $13^{\circ} \mathrm{C}$ (Fig. 10.6C) (salinidades de $\sim 0$ a 20 eq. $\%$ em peso do $\mathrm{NaCl}$ ). A homogeneização total ocorre pela expansão das fases carbônica, aquosa e para o estado crítico (em função do grau de preenchimento variado), em temperaturas de $360^{\circ}$ a $>600^{\circ} \mathrm{C}$ (Fig. 10.6D).

\section{Grupo B}

As inclusões fluidas do grupo $B$ apresentam temperaturas eutéticas principalmente no intervalo de -65 a $-40^{\circ} \mathrm{C}$ (Fig. 10.7A) e temperaturas de fusão do gelo entre -28 e $-21^{\circ} \mathrm{C}$ (Fig. 10.7B). A homogeneização total ocorre principalmente pela dissolução de cristais de saturação, mas devido ao tamanho muito pequeno das inclusões fluidas, poucos dados foram obtidos. A dissolução da halita e a homogeneização da fase fluida (para o estado líquido), ocorrem entre 240 e $380^{\circ} \mathrm{C}$ e entre 150 e $380^{\circ} \mathrm{C}$, respectivamente (Fig. 10.7C). Esses dados indicam salinidades entre 30 a 44 eq. \% em peso do $\mathrm{NaCl}$. 


\section{Grupo C}

A fusão do $\mathrm{CO}_{2}$ nas inclusões carbônicas e aquocarbônicas do grupo $\mathrm{C}$ ocorre entre $-58,1$ a $-57,4^{\circ} \mathrm{C}$ (Fig. 10.6A), sugerindo a presença de $\mathrm{CO}_{2}$ bastante puro. A homogeneização do $\mathrm{CO}_{2}$ ocorre para o estado liquido entre 20,1 e $25,5^{\circ} \mathrm{C}$ (Fig. 10.6B), indicando que suas densidades variam de 0,70 a $0,77 \mathrm{~g} / \mathrm{cm}^{3}$. As inclusões aquosas associadas apresentam temperaturas eutéticas variando de -45 a $-40^{\circ} \mathrm{C}$ (Fig. 10.7A). A fusão do gelo ocorre entre -14 e $-10^{\circ} \mathrm{C}$ (Fig. 10.7B), indicando salinidades de 13,6 a 17,6 eq. \% em peso do $\mathrm{NaCl}$. A homogeneização total, para o estado liquido, deu-se entre $100^{\circ}$ e $190^{\circ} \mathrm{C}$ (Fig. 10.7D).

\section{Grupo D}

As inclusões essencialmente aquosas do grupo $D$ apresentam temperaturas eutéticas variando de $-36 \mathrm{a}-31^{\circ} \mathrm{C}$ (Fig. 10.8A). A fusão do gelo entre -7 e $-5^{\circ} \mathrm{C}$ (maior quantidade de medidas - Fig. 10.8B), indica salinidades de 8 a $10 \mathrm{eq} . \%$ em peso do $\mathrm{NaCl}$. Deve-se ressaltar que no resfriamento destas inclusões ocorreu o fenômeno de "duplo congelamento", sugerindo a formação de clatratos. No entanto, a dissociação destes compostos não foi observada no aquecimento natural das inclusões, talvez devido à quantidades muito ínfimas de outro componente volátil associado à fase aquosa. A homogeneização total, para o líquido, varia de 230 a $340^{\circ} \mathrm{C}$ (Fig. 10.8C).

Nas inclusões constituídas por água e metano, os clatratos se dissociam ao redor de $14^{\circ} \mathrm{C}$ (Fig. 10.8D), sugerindo salinidades baixas. A homogeneização total ocorre pela expansão da fase aquosa ou rica em metano, no intervalo de 280 a $390^{\circ} \mathrm{C}$ (Fig. $10.8 \mathrm{C}$ ).

\section{Grupo E}

O grupo E pode ser dividido em três subgrupos pelos dados microtermométricos.

As inclusões do subgrupo E1 apresentam temperaturas eutéticas entre $-78,2$ e $\ldots$ $74,6^{\circ} \mathrm{C}$ (Fig. 10.7A). A fusão do gelo entre $-38,9$ e $-33,6^{\circ} \mathrm{C}$ (Fig. 10.7B), sugere salinidades muito altas, mas que não podem ser determinadas em função destes valores situarem-se abaixo do eutético estável do sistema $\mathrm{H}_{2} \mathrm{O}-\mathrm{NaCl}\left(=-21,8^{\circ} \mathrm{C}\right)$. De qualquer modo, as salinidades são maiores que $23,02 \mathrm{eq}$. $\%$ em peso do $\mathrm{NaCl}$. A homogeneização total, sempre para o estado líquido, situa-se no intervalo de 85 a $143^{\circ} \mathrm{C}$ (Fig. 10.7D).

Os valores eutéticos das inclusões do subgrupo E2 variam de -43 a $-26^{\circ} \mathrm{C}$ (Fig. 10.7A). A fusão do gelo entre -16 e $0^{\circ} \mathrm{C}$ (Fig. 10.7B), indica salinidades entre $\sim 0$ e 20 eq. $\%$ em peso do $\mathrm{NaCl}$. A homogeneização total ocorre sempre para o estado liquido entre 110 e $150^{\circ} \mathrm{C}$ (Fig. 10.7D). 
O subgrupo E3 é formado por inclusões aquosas mais tardias, de baixa salinidade $\left(\sim 5,6\right.$ eq. \% em peso do $\mathrm{NaCl}$ - fusão do gelo $\left.\sim-3,5^{\circ} \mathrm{C}\right)$, com temperaturas eutéticas em torno de $-37,4^{\circ} \mathrm{C}$ e de homogeneização total ao redor de $85^{\circ} \mathrm{C}$, para o estado líquido. Devido a pequena ocorrência, esse grupo de inclusões fluidas não foi estudado com detalhe. De qualquer modo, são importantes para caracterização da evolução de fluidos da ZCR.

\section{Grupo F}

A fusão do $\mathrm{CO}_{2}$ nas inclusões carbônicas sin-deformacionais do grupo $\mathrm{F}$, ocorre principalmente entre $-57,9$ a $-57,3^{\circ} \mathrm{C}$ (Fig. 10.9A), sugerindo quantidades muito pequenas de outros componentes junto ao $\mathrm{CO}_{2}$. A homogeneização, sempre para o estado líquido, ocorre entre 9 e $22^{\circ} \mathrm{C}$ (Fig. 10.9B), indicando um intervalo de densidade relativamente amplo $\left(0,76\right.$ a $\left.0,87 \mathrm{~g} / \mathrm{cm}^{3}\right)$.

\subsubsection{Veios extensionais}

\section{Grupo 1}

A fusão do $\mathrm{CO}_{2}$ nas inclusões do grupo 1 (carbônicas e aquocarbônicas) ocorre entre $-58,2$ e $-57,1^{\circ} \mathrm{C}$ (Fig. 10.10A), indicando pequenas quantidades de outros componentes voláteis associados. O padrão de distribuição das homogeneizações do $\mathrm{CO}_{2}$ variam em função da amostra analisada. Na amostra F200, a homogeneização ocorre para o estado líquido em ambas inclusões (carbônicas e aquocarbônicas), em temperaturas entre 15,2 e $25,2^{\circ} \mathrm{C}$ ( Fig. 10.10B), mostrando densidades entre 0,71 a 0,82 $\mathrm{g} / \mathrm{cm}^{3}$. Na amostra $\mathrm{F} 198$, a homogeneização do $\mathrm{CO}_{2}$ ocorre para os estados líquido, gás e crítico, entre 21,0 e $30,2^{\circ} \mathrm{C}$ (Fig. 10.10B), indicando grande contraste de densidade $\left(0,29\right.$ a $\left.0,76 \mathrm{~g} / \mathrm{cm}^{3}\right)$.

Diferentes comportamentos de mudanças de fase também foram observados na dissociação de clatratos e na homogeneização total. Enquanto na amostra F200 a dissociação de clatratos ocorre entre 0,3 a $13^{\circ} \mathrm{C}$ (salinidades variando de $\sim 0$ a 15 eq. \% em peso do $\mathrm{NaCl}$ ), na amostra $\mathrm{F} 198$ ocorre entre 6,8 e $8,0^{\circ} \mathrm{C}$ (Fig. 10.10C), indicando salinidades entre 4 e 6 eq. $\%$ em peso do $\mathrm{NaCl}$. A homogeneização total ocorreu para os estados líquido e gás na amostra F200, em temperaturas entre 223 e $414^{\circ} \mathrm{C}$. Na amostra F198 observou-se apenas homogeneização total para o estado líquido, em temperaturas entre 142 e $264^{\circ} \mathrm{C}$ (Fig. 10.10D). Deve-se ressaltar que apesar disso, foram identificadas inclusões com graus de preenchimento baixos (menores que 50), mas que não foram observadas no aquecimento. 


\section{Grupo 2}

As temperaturas eutéticas das inclusões do grupo 2 variam de $-46,5$ a $-35,5^{\circ} \mathrm{C}$ (Fig. 10.11A). A fusão do gelo ocorre entre $-8,7$ a $-8,1^{\circ} \mathrm{C}$ (Fig. 10.11B), indicando salinidades ao redor de $12 \mathrm{eq}$. $\%$ em peso do $\mathrm{NaCl}$. A homogeneização total, sempre para o estado líquido, ocorre principalmente entre 155 e $210^{\circ} \mathrm{C}$ (Fig. 10.11C).

\subsection{Espectroscopia Raman}

Nos veios paralelos à foliação milonítica, as inclusões fluidas do grupo $A$ apresentaram temperaturas de fusão do $\mathrm{CO}_{2}$ muito abaixo do ponto triplo deste $\left(-56,6^{\circ} \mathrm{C}\right)$, sugerindo importantes quantidades de outros voláteis presentes na fase carbônica. Análises por espectroscopia Raman em quatro dessas inclusões, sendo três carbônicas e uma aquocarbônica, revelaram que o rebaixamento do ponto triplo do $\mathrm{CO}_{2}$ é causado pela presença unicamente do $\mathrm{CH}_{4}$ (Fig. 10.12).

Ainda em relação aos veios paralelos à foliação milonítica foi analisada uma inclusão carbônica sin-deformacional (grupo F) e uma inclusão constituída por água e metano (grupo D). Dessas, a primeira forneceu uma composição de 97,89 moles $\%$ de $\mathrm{CO}_{2}$ e 2,71 moles $\%$ de $\mathrm{N}_{2}$ e na segunda foi detectada a presença de $\mathrm{CH}_{4}$ puro além da água (Fig. 10.12).

Duas inclusões aquocarbônicas presentes em amostra de vênula extensional (Grupo 1), mostraram a presença de traços de $\mathrm{CH}_{4}$ e $\mathrm{N}_{2}$ junto a fase carbônica (Fig. 10.12).

A combinação dos dados de microtermometria e espectroscopia Raman permitiu o cálculo da porcentagem de $\mathrm{CH}_{4}$ presente na fase carbônica, com base no método gráfico discutido por Shepherd et al. (1985). As composições resultantes mostraram que na fase carbônica das inclusões do grupo A estão presentes de 15 a $30 \mathrm{~mol}^{\circ}$ de $\mathrm{CH}_{4}$, enquanto nas inclusões do grupo 1 a porcentagem alcança no máximo $8 \mathrm{~mol} \%$.

\subsection{Discussão}

\subsubsection{Processos e estágios de aprisionamento de Inclusões fluidas}

10.6.1.1. Veios paralelos à foliação milonitica

A integração dos dados petrográficos, microtermométricos e de espectroscopia Raman, permitiu a caracterização de seis estágios de geração de inclusões fluidas nos veios paralelos à foliação milonítica (Tabela 10.1). 


\begin{tabular}{|c|c|c|c|c|c|c|c|c|c|c|c|}
\hline Grupo & Veio & Natureza & Sistema & $\begin{array}{l}T f_{\mathrm{CO} 2} \\
\left({ }^{\circ} \mathrm{C}\right)\end{array}$ & $\begin{array}{l}\text { TheO2 } \\
\left({ }^{\circ} \mathrm{C}\right)\end{array}$ & $\begin{array}{l}\mathrm{Tf}_{\mathrm{Cl}} \\
\left({ }^{\circ} \mathrm{C}\right)\end{array}$ & $\begin{array}{l}\text { TE } \\
\left({ }^{\circ} \mathrm{C}\right)\end{array}$ & $\begin{array}{l}\mathrm{Tf}_{\text {geto }} \\
\left({ }^{\circ} \mathrm{C}\right)\end{array}$ & $\begin{array}{l}T_{\text {total }} \\
\left({ }^{\circ} \mathrm{C}\right)\end{array}$ & $\begin{array}{c}\mathrm{D}_{\mathrm{CO} 2} \\
\left(\mathrm{~g} / \mathrm{cm}^{3}\right)\end{array}$ & $\begin{array}{l}\text { Salinidade } \\
\text { Eq. \% peso } \mathrm{NaCl}\end{array}$ \\
\hline $\bar{A}$ & paraleto & primària & $\begin{array}{l}\mathrm{CO}_{2}-\mathrm{CH}_{4} \\
\mathrm{H}_{2} \mathrm{O}-\mathrm{CO}_{2}-\mathrm{CH}_{4}-\mathrm{NaCl}\end{array}$ & $\begin{array}{l}-62,2 /-59,4 \\
-66,6 /-58,9\end{array}$ & $\begin{array}{l}-13,1 / 17,0 \mathrm{~L} \\
8,0 / 12,2 \mathrm{G} \\
-3,5 /-5,4 \mathrm{~L} \\
3,7 / 6,7 \mathrm{G}\end{array}$ & $\begin{array}{c}- \\
- \\
-6,5 / 12,9\end{array}$ & - & - & $360 />600$ & $\begin{array}{l}0,15 / 1,00 \\
0,11 / 0,95\end{array}$ & $\begin{array}{l}- \\
-0 / 19,9\end{array}$ \\
\hline$B$ & paralelo & primánia? & $\mathrm{H}_{2} \mathrm{O}-\mathrm{CaCl}_{2}-\mathrm{NaCl}$ & - & - & - & $-78,0 /-45,0$ & $-26,8 / \cdot 21,2$ & $163 / 371$ & - & $30,9 / 44,5$ \\
\hline c & paralelo & secundána & $\begin{array}{l}\mathrm{CO}_{2}-\mathrm{CH}_{4} \\
\mathrm{H}_{2} \mathrm{O}-\mathrm{CO}_{2}-\mathrm{CH}_{2}-\mathrm{NaCl} \\
\mathrm{H}_{2} \mathrm{O}-\mathrm{CaCl}_{2}-\mathrm{NaCl}\end{array}$ & $\begin{array}{c}-58,1 /-57,4 \\
-58,0 /-57,5 \\
-\end{array}$ & $\begin{array}{c}20,7 / 25,5 L \\
- \\
-\end{array}$ & $\begin{array}{c}- \\
1,0 / 9,9 \\
-\end{array}$ & $\begin{array}{c}- \\
- \\
-45,0 /-37,4\end{array}$ & $\begin{array}{c}- \\
- \\
-13,8 /-9,7\end{array}$ & $\begin{array}{c}- \\
- \\
101 / 255\end{array}$ & $\begin{array}{c}0,70 / 0,77 \\
- \\
-\end{array}$ & $\begin{array}{c}- \\
-0 / 14,7 \\
13,6 / 17,6\end{array}$ \\
\hline$D$ & paralelo & primária & $\begin{array}{l}\mathrm{H}_{2} \mathrm{O}-\mathrm{CH}_{4}-\mathrm{NaCl} \\
\mathrm{H}_{2} \mathrm{O}-\left(\mathrm{CH}_{4}\right)-\mathrm{NaCl}\end{array}$ & - & - & $\begin{array}{c}-1,4 / 14,6 \\
-\end{array}$ & $-30,4 i-39,7$ & $-8,1 /-3,1$ & $\begin{array}{l}298 / 586 \\
237 / 330\end{array}$ & - & $\begin{array}{c}? \\
5,0 / 11,9\end{array}$ \\
\hline $\begin{array}{l}E 1 \\
E 2 \\
E 3\end{array}$ & $\begin{array}{l}\text { paralelo } \\
\text { paraielo } \\
\text { paraielo }\end{array}$ & $\begin{array}{l}\text { secundária } \\
\text { secundária } \\
\text { secundária }\end{array}$ & $\begin{array}{l}\mathrm{H}_{2} \mathrm{O}-\mathrm{CaCl}_{2}-\mathrm{NaCl}(\mathrm{LiCl} ?) \\
\mathrm{H}_{2} \mathrm{O}-\mathrm{CaCl}_{2}-\mathrm{NaCl} \\
\mathrm{H}_{2} \mathrm{O}-\mathrm{CaCl}_{2}-\mathrm{NaCl}\end{array}$ & - & $\begin{array}{l}- \\
-\end{array}$ & - & $\begin{array}{l}-79,4 /+74,6 \\
-44,9 /-28,3 \\
-40,0 /-35,0\end{array}$ & $\begin{array}{l}-38,9 /-33,6 \\
-16,2 /-0,6 \\
-4,0 /-3,0\end{array}$ & $\begin{array}{l}85 / 143 \\
122 / 149 \\
80 / 90\end{array}$ & $\begin{array}{l}- \\
- \\
-\end{array}$ & $\begin{array}{l}>23,02 \\
-0 / 20,0 \\
5,0 / 6.5\end{array}$ \\
\hline$F$ & paralelo & $\begin{array}{l}\sin \cdot \\
\text { deformacional }\end{array}$ & $\mathrm{CO}_{2} \cdot \mathrm{N}_{2}$ & $-58,7 /-56,8$ & $9,1 L / 21,5 \mathrm{~L}$ & - & - & - & - & $, 78 / 0,87$ & - \\
\hline 1 & extensional & primána & $\begin{array}{l}\mathrm{CO}_{2}-\mathrm{CH}_{4}-\left(\mathrm{N}_{2}\right) \\
\mathrm{H}_{2} \mathrm{O}-\mathrm{CO}_{2}-\mathrm{CH}_{4}-\left(\mathrm{N}_{2}\right)-\mathrm{NaCl}\end{array}$ & $\begin{array}{l}-58,2 /-57,6 \\
-58,5 /-56,8\end{array}$ & $\begin{array}{l}20,1 \mathrm{~L} / 25,2 \mathrm{~L} \\
15,2 \mathrm{~L} / 30,1 \mathrm{C} \\
25,9 \mathrm{G} / 30,2 \mathrm{G}\end{array}$ & $0,3 / 12,7$ & - & - & $\begin{array}{c}- \\
167 / 389\end{array}$ & $\begin{array}{l}0,71 / 0,77 \\
0,35 / 0,82\end{array}$ & $\begin{array}{c}- \\
-0 / 14,8\end{array}$ \\
\hline 2 & extensional & secundária & $\mathrm{H}_{2} \mathrm{O}-\mathrm{CaCl}_{2}-\mathrm{NaCl}$ & - & - & - & $-46,5 /-35,7$ & $-9,3 /-6,4$ & $119 / 255$ & - & $9,7 / 13,2$ \\
\hline
\end{tabular}

Tabela 10.1. Síntese dos resultados microtermométricos 


\section{Estágio Pl (Grupo A)}

Os resultados obtidos mostram que as inclusões carbônicas e aquocarbônicas presentes no grupo A são seguramente primárias e representam os fluidos mais primitivos relacionados com a formação dos veios de quartzo.

De acordo com os critérios apresentados por Ramboz et al. (1982), as inclusões fluidas desse grupo apresentam evidências inequívocas de aprisionamento heterogêneo. Tais critérios consistem de:

a) evidências texturais de aprisionamento simultâneo de dois tipos diferentes de fluidos (fluidos carbônicos e aquocarbônicos, no caso);

b) evidências seguras da ausência de processos de modificações, tais como leakage e necking-down;

c) ocorrência de inclusões fluidas com variados graus de preenchimento, temperaturas de homogeneização e composições; e

d) Diagramas de freqüência de temperaturas de homogeneização total não simétricos, onde as homogeneizações ocorrem ora pela expansão da fase aquosa, nas inclusões ricas em $\mathrm{H}_{2} \mathrm{O}$ e, ora da fase carbônica, naquelas onde predomina $\mathrm{O}_{2}$, em temperaturas relativamente semelhantes, dependendo das proporçōes relativas dos componentes.

Os mesmos autores enfatizam que o aprisionamento heterogêneo constitui uma evidência simples e boa de imiscibilidade (Ramboz et al., 1982; pag. 37).

Segundo alguns autores (e.g. Bower \& Helgeson, 1983; Bodnar et al., 1985; Anderson et al., 1992) em inclusões aprisionadas heterogeneamente a partir de um sistema constituido por água, $\mathrm{CO}_{2}$ e sais, a salinidade da fase aquosa pode variar sistematicamente de acordo com a proporção de $\mathrm{CO}_{2}$, de forma que quanto maior a porcentagem deste componente, menor a salinidade da fase aquosa. No nosso caso observamos padrões diferentes dependendo da amostra analisada. Enquanto na amostra F45, as inclusões aquocarbônicas apresentaram salinidades pouco variáveis, na amostra F254, observamos diferentes padrões de distribuição de salinidade em campos diferentes (Fig. 10.13A, B). Independente do grau de preenchimento, na amostra F254, ocorrem campos onde a salinidade é aproximadamente constante contrastando com outros onde é bastante variável. Essas evidências sugerem que localmente ocorreram misturas parciais com fluidos mais salinos. As observações petrográficas corroboram com essa interpretação, uma vez que, nos campos onde as inclusões aquocarbônicas do grupo $A$ apresentam salinidades muito variáveis, estas ocorrem associadas com as inclusões 
aquossalinas do grupo B. Além disso, nesses campos as inclusões carbônicas são ausentes.

De acordo com as discussões acima, interpretamos que as inclusões carbônicas e aquocarbônicas do grupo A representam fluidos desmisturados a partir de um fluido originalmente homogêneo e que localmente foi misturado com fluidos mais salinos e de menores temperaturas, representados pelas inclusões fluidas do grupo $B$.

Roedder (1984) discute que em inclusões fluidas aprisionadas a partir de processos de imiscibilidade ou "boiling" (no caso de inclusões cujas fases líquida e vapor são constituidas pelo mesmo componente), os valores mais próximos das temperaturas reais de aprisionamento são representados pelas menores temperaturas de homogeneização total obtidas, uma vez que estas foram aprisionadas o mais próximo possivel da curva de solvus. Dessa forma, podemos considerar que as inclusões do grupo $\mathrm{A}$ foram aprisionadas entre $360^{\circ} \mathrm{C}$ e $380^{\circ} \mathrm{C}$ (Fig. 10.6D, Tabela 10.1).

Adicionalmente, observa-se diferenças significativas das densidades do $\mathrm{CO}_{2}$ nas inclusões desse grupo (Tabela 10.1). Enquanto em algumas regiões a homogeneização do $\mathrm{CO}_{2}$ ocorre para o estado liquido em temperaturas pouco variáveis, em outros campos a homogeneização ocorre sempre para o gás, indicando densidades muito contrastantes $\left(0,29\right.$ a $\left.0,95 \mathrm{~g} / \mathrm{cm}^{3}\right)$. Como modificações posteriores ao aprisionamento são descartadas, interpretamos que as diferenças de densidade são resultado de flutuação da pressão. No entanto, considerando somente as inclusões cuja homogeneização do $\mathrm{CO}_{2}$ ocorre para o líquido, observamos na figura $10.13 \mathrm{C}$ uma correlação positiva entre $\mathrm{Tf}_{\mathrm{CO} 2}$ e $\mathrm{Th}_{\mathrm{CO}}$, indicando que em parte a variação da temperatura de homogeneização do $\mathrm{CO}_{2}$ deve-se a composição (quanto maior a quantidade de metano, menor é a Th $\mathrm{CO}_{\mathrm{C} 2}$ da fase volátil). Apesar dessa influência mascarar os efeitos da flutuação de pressão, o simples fato de ocorrerem homogeneizações para o estado líquido e gás já indica grandes contrastes de densidade.

\section{Estágio P2 (Grupo B)}

Temperaturas eutéticas associadas a presença cristais de saturação de halita nas inclusões do grupo $B$ indicam que estas representam soluções pertencentes ao sistema $\mathrm{CaCl}_{2}-\mathrm{NaCl}_{2}-\mathrm{H}_{2} \mathrm{O}$. Os desvios em relação ao eutético estável desse sistema puro ( $\mathrm{T}=$ $52^{\circ} \mathrm{C}$ ), podem denunciar a presença de outros sais dissolvidos, tais como $\mathrm{MgCl}_{2}, \mathrm{FeCl}_{3}$, $\mathrm{KCl}, \mathrm{AlCl}_{3}$, ou ainda estar associados a metaestabilidade do sistema $\mathrm{CaCl}_{2}-\mathrm{NaCl}_{2}-\mathrm{H}_{2} \mathrm{O}$, uma vez que inclusões com estas composições geralmente produzem assembléias metaestáveis em temperaturas abaixo do eutético (Goldstein \& Reynolds, 1994). Exemplos dessas assembléias são mostradas abaixo: 


$$
\begin{aligned}
& \text { vapor + gelo + halita }+\mathrm{CaCl}_{2}\left(4 \mathrm{H}_{2} \mathrm{O}\right) \\
& \text { vapor + gelo + halita + antarcticita }
\end{aligned}
$$

Essas assembléias podem produzir eutéticos metaestáveis ao redor de $-70^{\circ} \mathrm{C}$ pela reação de gelo com $\mathrm{CaCl}_{2}\left(4 \mathrm{H}_{2} \mathrm{O}\right)$ formando $\mathrm{CaCl}_{2}\left(6 \mathrm{H}_{2} \mathrm{O}\right)$ (Goldstein \& Reynolds, 1994).

Altas salinidades são indicadas pela presença de halita de saturação em todas inclusões desse grupo. A dissolução desses sólidos, na maioria dos casos observados, ocorre em temperaturas (Ts) superiores as de homogeneização da fase fluida (Th)

Inclusões fluidas onde as Ts excede as Th podem ocorrer em três casos: 1) aprisionamento de um fluido em boiling saturado com respeito a um ou mais sólidos (Ramboz et al. 1982; Shepherd et al., 1985); 2) salmouras homogeneamente muito concentradas, supersaturadas em altas T e P; ou 3) aprisionamento de soluções livres de vapor saturadas em alkali-cloretos (Cloke \& Kessler, 1979).

Uma solução em boiling saturada é aprisionada na curva onde coexistem $\mathrm{V}+\mathrm{L}+\mathrm{H}$, e neste caso as temperaturas de dissolução da halita e de homogeneização da fase fluida devem ocorrer nos mesmos intervalos (Ramboz et al., 1982). No entanto, os mesmos autores citaram a possibilidade de aprisionamento de quantidades variáveis de sólidos nestas soluções, desde que os valores mais baixos de Ts se situem nos mesmos intervalos de variação da Th. Alguns autores enfatizam que como suporte de semelhante interpretação é necessário o reconhecimento de evidências petrográficas de aprisionamento heterogêneo, tais como graus de preenchimento variáveis num mesmo grupo de inclusões (Cloke \& Kessler, 1979; Shepherd et al., 1985).

Nas as inclusões do grupo B ocorre grande variação da salinidade em um intervalo pequeno de variação da Th (Fig. 10.14). Como não existem inclusões com graus de preenchimento variáveis e as Ts sempre excedem as Th, a hipótese de boiling pode ser descartada.

Salmouras homogêneas muito concentradas, aprisionadas em altas $T$ e $P$, caracterizam-se pelos intervalos constantes de Th e Ts, sendo os últimos mais elevados A grande variação das Ts (e portanto das salinidades) das inclusões do grupo B exclui essa possibilidade.

Levando-se em conta as discussões acima, interpretamos que o intervalo pouco variável de Th frente a grande variação de Ts pode ser resultado do aprisionamento heterogêneo de um fluido aquoso saturado e livre de vapor, porém já contendo halita precipitada. Nesse caso grande parte da halita deve ter sido aprisionada como fases sólidas em variadas proporções de inclusão para inclusão, o que impossibilita sabermos qual era a salinidade real da fase fluida na época do aprisionamento. 
Pelos dados microtermométricos podemos considerar que as inclusões desse grupo foram aprisionadas em temperaturas minimas entre 250 e $270^{\circ} \mathrm{C}$, que seria 0 intervalo das menores temperaturas de dissociação da halita (Figs. 10.7C, 10.14).

\section{Estágio P3 (Grupo C)}

As inclusões fluidas do grupo $\mathrm{C}$ apresentam evidências petrográficas muito fortes de aprisionamento de fluidos em condiçōes subsolvus, visto que foi observada, em trithas individuais, a coexistência de inclusões carbônicas, aquocarbônicas e aquosas. Como as inclusões aquocarbônicas são raríssimas nestas trithas, e não puderam ser analisadas, não foi possivel avaliar outros criterios do aprisionamento de fluidos imisciveis.

Segundo Ramboz et al. (1982) os processos de imiscibilidade metaestável de fluidos misciveis coexistentes (decorrentes de mistura de fluidos), não pode persistir por muito tempo em função da alta razão de difusão e da usualmente intensa mobilidade física dos líquidos (fluxos laminar, turbulento, etc.). Conforme os autores, trabalhos experimentais no limite $L+V$ indicam que condições de equilibrio químico são geralmente atingidas dentro de poucos dias ou em poucas horas. Comparados com as taxas da dinâmica de fluidos, crescimento de cristais, cicatrização de fraturas e, portanto, do aprisionamento de inclusões fluidas em processos naturais, estes valores são muito baixos. Desse modo a hipótese de imiscibilidade é a mais provável.

As temperaturas eutéticas das inclusões aquosas sugerem soluções do sistema $\mathrm{CaCl}_{2}-\mathrm{NaCl}-\mathrm{H}_{2} \mathrm{O}$. No entanto, as temperaturas mais altas $\left(-45 \mathrm{a}-40^{\circ} \mathrm{C}\right)$ em relação ao grupo $B(-65$ a -40$)$, sugerem que nesse caso não deve haver grande contribuição de outros sais dissolvidos. As temperaturas de fusão do gelo indicam salinidades moderadas e relativamente constantes $(13,6$ a $17,6 \mathrm{eq}$. \% em peso do $\mathrm{NaCl}$ ). Essa situação torna improvável a ocorrência de misturas de fluidos, e corrobora com as outras evidências de que as inclusões foram aprisionadas em condições subsolvus.

Baseado nos critérios de Roedder (1984) sobre o aprisionamento de incluões subsolvus podemos considerar que este grupo de inclusões foi aprisionado em temperaturas entre 160 e $180^{\circ} \mathrm{C}$, sendo este o intervalo médio das temperaturas de homogeneização obtidas nas inclusões aquosas (Fig. 10.7D).

\section{Estágio P4 (Grupo D)}

Nos veios onde ocorrem inclusões fluidas essencialmente aquosas e inclusões constituídas por água e metano, as primeiras apresentaram temperaturas de homogeneização total concentradas entre 245 e $265^{\circ} \mathrm{C}$ (Fig. 10.8C). As temperaturas de 
homogeneização total, de certo modo, apresentam grandes variações para salinidades aproximadamente constantes, tornando improvável uma evolução por mistura de fluidos.

Não existem evidências petrográficas de que as inclusões essencialmente aquosas sejam geneticamente associadas com as inclusões constituídas por água e metano, visto que cada grupo ocorre em regiões distintas da amostra, apesar de ambas serem primárias.

As inclusões constituídas por água e metano apresentam evidências petrográficas (variados graus de preenchimento, ausência de feições de modificações) e microtermométricas (homogeneização total pela expansão das fases aquosas ou rica em metano, em função do grau de preenchimento) de que foram aprisionadas em condições subsolvus. Suas salinidades são, de modo geral, baixas, como pode ser observado pelas temperaturas de dissociação de clatratos que variaram entre -13 e $-14^{\circ} \mathrm{C}$ (Fig. 10.8D). $\mathrm{O}$ intervalo relativamente constante de salinidade torna improvável a ocorrência de misturas parciais de fluidos.

Baseados nos critérios de Roedder (1984) sobre as temperaturas de aprisionamento em caso de imiscibilidade, interpretamos que essas inclusões foram aprisionadas ao redor de $300^{\circ} \mathrm{C}$ (Fig. 10.8C. Tabela 10.1).

Considerando-se todos os fragmentos da amostra estudada, os dados discutidos anteriormente sugerem que, embora localmente seja clara a ocorrência de processos de imiscibilidade (inclusões constituidas por $\mathrm{H}_{2} \mathrm{O}+\mathrm{CH}_{4}$ de baixa salinidade e Th $>300^{\circ} \mathrm{C}$ ), num sentido mais amplo os fluidos evoluiram no sentido de sistemas aquosos cada vez mais salinos e pobres em $\mathrm{CH}_{4}$, aprisionados em temperaturas cada vez mais baixas (inclusões essencialmente aquosas, salinidade entre 8 e 10 eq. $\%$ em peso do $\mathrm{NaCl}$, com Th entre 245 e $265^{\circ} \mathrm{C}$ ). Essa situação pode ser explicada por diferentes estágios de geração de inclusões fluidas, que podem estar ligados a diferentes etapas de formação do veio hospedeiro (F49), conforme sugerido também pelas microestruturas (ver item 10.1.2).

\section{Estágio P5 (Grupo E)}

As inclusões fluidas do grupo $E$ representam pulsos aquosos posteriores à formação dos cristais, sempre com soluções do sistema $\mathrm{CaCl}_{2}-\mathrm{NaCl}_{2}-\mathrm{H}_{2} \mathrm{O}$. Os vários intervalos de temperaturas eutéticas e salinidades, além das diferentes direções das trilhas analisadas indicam que estes fluidos estão associados a vários estágios de aprisionamento, motivo este de sua subdivisão em três subgrupos, conforme discutido na pagina 99 . 
Em relação aos valores eutéticos o subgrupo $E 1$ merece consideraçōes adicionais pelas baixas temperaturas (entre -75 e $-78^{\circ} \mathrm{C}$ - Tabela 10.1). Apesar de vários autores considerarem que estes valores podem ser resultado de metaestabilidade do sistema $\mathrm{CaCl}_{2}-\mathrm{NaCl}_{2}-\mathrm{H}_{2} \mathrm{O}$ (e.g. Goldstein \& Reynolds, 1994), também poderiam indicar a presença de sais exóticos como por exemplo LiCl (Borizenko, 1978 apud Roedder, 1984). No entanto, as considerações sobre a presença desse sistema na bibliografia tem sido utilizadas com cautela, somente nos casos onde outras características geológicas sugerem a possibilidade da ocorrência do lítio. Outra caracteristica importante desse grupo de inclusões é a definida pelas baixas temperaturas de fusão do gelo (de -34 a $39^{\circ} \mathrm{C}$, Tabela 10.1), corroborando com a hipótese de ocorrência de outros cátions além de $\mathrm{Na}$ e Ca. Como não sabemos ao certo a fonte destes fluidos, essa questão não pode ser resolvida até o momento.

Como a variação das temperaturas eutéticas e de fusão do gelo está ligada a diferentes trithas, isto é, em cada trilha individual praticamente não ocorre variação, é improvável que tenha ocorrido mistura de fluidos.

As temperaturas mínimas de aprisionamento das inclusões desse grupo variam de $85^{\circ}$ a $150^{\circ} \mathrm{C}$.

\section{Estágio P6 (Grupo F)}

Diversas evidências petrográficas indicam que as inclusões do grupo $F$ foram geradas concomitantemente com a milonitizaçăo dos veios de quartzo hospedeiro. Tais feições consistem de: (1) inclusões carbônicas em trilhas transgranulares em porfiroclastos; (2) inclusões carbônicas em arranjo aleatório em cristais neoformados; (3) inclusões carbônicas em junções tríplice de subgrãos; (4) mesmas composições e distribuição de densidades, independentes do modo de ocorrência; e (5) ausência de qualquer outro tipo de inclusão fluida.

Dessa forma podemos considerar que estas inclusões foram aprisionadas em temperaturas ao redor de $450-500^{\circ} \mathrm{C}$, conforme interpretamos pelos padrões de distribuição das tramas de eixo c de quartzo da amostra analisada (F42B - Fig. 9.1), além das paragêneses metamórficas associadas os milonitos encaixantes dos veios.

Grandes diferenças de densidade, independente do modo de ocorrência, aliados a ausência de feições de modificação posteriores ao aprisionamento das inclusões sugerem importantes processos de flutuação da pressão. O diagrama relacionando $\mathrm{Th}_{\mathrm{CO} 2}$ com $\mathrm{Tf}_{\mathrm{CO} 2}$ (Fig. 10.15), corrobora com essa interpretação, mostrando que as variações de $\mathrm{Th}_{\mathrm{CO} 2}$ não estão relacionadas com variações da composição. 


\subsubsection{Veios extensionais}

Os dados petrográficos e microtermométricos expostos anteriormente permitem interpretar apenas dois estágios de geração de inclusões fluidas nos veios extensionais. Essa situação mostra claramente que os veios extensionais e paralelos não encontramse associados temporalmente confirmando as observações de campo.

\section{Estágio El (Grupo 1)}

A coexistência entre inclusões carbônicas e aquocarbônicas com variados graus de preenchimento nas mesmas populações, a ausência de evidências de processos de modificações e as homogeneizações totais ocorridas pela expansão das fases aquosa e carbônica nos mesmos intervalos de temperatura sugerem que as inclusões do grupo 1 nos veios extensionais também foram aprisionadas em condições subsolvus. No entanto estas inclusões diferenciam-se daquelas formadoras do grupo A, nos veios paralelos, pela forma mais pura de ocorrência do $\mathrm{CO}_{2}$ e pelas temperaturas muito mais baixas de homogeneização total (Tabela 10.1).

Os valores de salinidade das inclusões aquocarbônicas podem ser relativamente constantes ou bastante variáveis, dependendo da amostra. Para amostra F200, o diagrama relacionando temperaturas de dissociação de clatratos com grau de preenchimento mostra uma tênue correlação negativa (Fig. 10.16B), indicando que quanto maior a salinidade maior o grau de preenchimento. Esse padrão é esperado para inclusões aprisionadas a partir de fluidos imisciveis (Anderson et al., 1992) conforme discutido anteriormente e corrobora com esta interpretação.

As temperaturas mais proximas das reais de aprisionamento obtidas situam-se ao redor de 190 e $220^{\circ} \mathrm{C}$, respectivamente para as amostras F198 e F200 (Tabela 10.1).

As densidades do $\mathrm{CO}_{2}$ apresentam variações que independem do grau de preenchimento das inclusões e podem estar relacionadas com flutuação da pressão na época do aprisionamento.

\section{Estágio E2 (Grupo 2)}

As inclusöes fluidas do grupo 2 representam pulsos aquosos tardios à formação dos veios extensionais. As temperaturas eutéticas próximas a $-40^{\circ} \mathrm{C}$ sugerem soluções do sistema $\mathrm{CaCl}_{2}-\mathrm{NaCl}_{2}-\mathrm{H}_{2} \mathrm{O}$. A pequena variação das temperaturas eutéticas e de fusão do gelo torna improvável que tenha ocorrido mistura de fluidos. Considerando as faixas mais freqüentes de temperaturas de homogeneização total (Tab 10.1), interpretamos que essas inclusões fluidas foram aprisionadas em temperaturas minimas de 155 a $210^{\circ} \mathrm{C}$. 


\subsubsection{Determinação das condições de pressão no aprisionamento das inclusões}

Diferentes métodos de determinação da pressão de aprisionamento foram utilizados, em função dos processos envolvidos na formação de cada grupo de inclusões fluidas. A sintese dos resultados é mostrada na tabela 10.2 .

\begin{tabular}{|c|c|c|c|c|c|c|c|}
\hline Amostra & $\begin{array}{c}\text { Tipo } \\
\text { de velo }\end{array}$ & Natureza & Grupo & $\begin{array}{l}\text { Temperatura } \\
\text { microtermometria }\end{array}$ & $\begin{array}{l}\text { Temperatura } \\
\text { cruzamento } \\
\text { de is } \delta \text { coras }\end{array}$ & Pressão & $\begin{array}{c}\text { Processo } \\
\text { (aprisionamento) }\end{array}$ \\
\hline F45-F254 & paralelo & primária & A & $360-380^{\circ} \mathrm{C}$ & $330^{\circ} \mathrm{C}$ & $1 \mathrm{kbar}$ & Imiscibilidade \\
\hline F45-F254 & paralelo & pseudo-secundária & $B$ & $250-270^{\circ} \mathrm{C}$ & - & - & \\
\hline $\mathrm{F} 45$ & paralelo & secundária & $\mathrm{C}$ & $160-180^{\circ} \mathrm{C}$ & $210^{\circ} \mathrm{C}$ & 0,7 kbar & Imiscibilidade \\
\hline F49 & paralelo & primária & D & $\sim 300^{\circ} \mathrm{C}$ & - & - & Imiscibitidade \\
\hline F49 & paralelo & primária & $\mathrm{D}$ & $245-265^{\circ} \mathrm{C}$ & - & $0,7 \mathrm{kbar}$ & \\
\hline F 45 & paralelo & secundária & $E 1$ & $85-143^{\circ} \mathrm{C}$ & . & & \\
\hline $\mathrm{F} 254$ & paralelo & secundiària & E2 & $110-150^{\circ} \mathrm{C}$ & - & & \\
\hline $\mathrm{F} 45$ & paralelo & secundária & E3 & $\sim 85^{\circ} \mathrm{C}$ & - & & \\
\hline $\mathrm{F} 45$ & paralelo & sin-deformaçäo & $F$ & & $\left(450-500^{\circ} \mathrm{C}\right)^{*}$ & $1,5-2,1 \mathrm{kbar}$ & \\
\hline $\mathrm{F} 200$ & extensional & primária & 1 & $\sim 220^{\circ} \mathrm{C}$ & $210^{\circ} \mathrm{C}$ & $0,7 \mathrm{kbar}$ & Imiscibilidade \\
\hline F198 & extensional & primária & 1 & $-190^{\circ} \mathrm{C}$ & - & - & Imiscibilidade \\
\hline F200 & extensional & pseudo-secundảria & 2 & $155-210^{\circ} \mathrm{C}$ & - & & \\
\hline
\end{tabular}

Tabela 10.2. Pressão e temperatura de aprisionamento estimadas nos grupos de inclusōes fluidas

As inclusões fluidas primárias dos veios paralelos e extensionais (grupos $A$ e 1 , respectivamente) e secundárias do grupo $C$ (veios paralelos), propiciam as melhores condições para a determinação da pressão, visto que representam fluidos aprisionados em condições subsolvus (Roedder, 1984). Neste caso o cruzamento das isócoras representativas dos extremos de composições carbônica e aquosa fornece uma estimativa de pressão confiável.

Em cada um dos três casos selecionou-se pares de inclusões adequados para construção das isócoras. Os cálculos foram processados a partir das equações de Bowers \& Helgeson (1983) para o sistema $\mathrm{CO}_{2}-\mathrm{H}_{2} \mathrm{O}-\mathrm{NaCl}$ e de Brown \& Lamb (1989) para o sistema $\mathrm{H}_{2} \mathrm{O}$. No caso do sistema $\mathrm{CO}_{2}-\mathrm{CH}_{4}$ foram utilizadas as equações do sistema denominado de Soup (Halloway) no programa Flincor (Brown, 1989). Para todas as inclusões ricas em $\mathrm{CO}_{2}$ utilizadas na construção de isócoras foram calculadas as porcentagens de $\mathrm{CH}_{4}$ através do método gráfico apresentado por Shepherd et al. (1985).

O cruzamento das isócoras do grupo A (veios paralelos), forneceu valores de $1 \mathrm{kbar}$ e $330^{\circ} \mathrm{C}$ (Fig. 10.17, Tabe/a 10.2). A temperatura estimada abaixo daquela obtida 
pela microtermometria $\left(360-380^{\circ} \mathrm{C}\right)$, torna essa estimativa confiável (Ramboz et al., 1982).

O grupo 1 (veios extensionais) forneceu valores de $0,7 \mathrm{~Kb}$ ar e $210^{\circ} \mathrm{C}$ (Fig. 10.17 Tabela 10.2). Novamente o valor de temperatura estimado é menor que o minimo obtido pela microtermometria $\left(220^{\circ} \mathrm{C}\right)$, mostrando que há bastante coerência nos resultados determinados pelo cruzamento de isócoras.

As inclusões secundárias do grupo $\mathrm{C}$ forneceram valores de $0,7 \mathrm{kbar}$ e $210^{\circ} \mathrm{C}$ (Fig. 10.17. Tabela 10.2). Nesse caso a temperatura obtida pelo cruzamento das isócoras, apesar de próxima, é maior que o mínimo observado na microtermometria $\left(160-180^{\circ} \mathrm{C}\right)$. Ramboz et. al., (1982) enfatiza que nesses casos os fluidos não poderiam ter sido aprisionados em condições subsolvus, representando provavelmente misturas. No entanto, como essa diferença entre as temperaturas é muito pequena, podendo ser conseqüência de imprecisões decorrentes das aproximações composicionais que devem ser feitas para a utilização das equações no programa flincor e, como discutido anteriormente, os critérios de imiscibilidade apresentados por esse grupo de inclusões são muito fortes, os dados nos fazem optar por esta hipótese.

A interpretação dos dados das inclusões essencialmente aquosas do grupo D utilizando-se equações de estado do sistema $\mathrm{H}_{2} \mathrm{O}-\mathrm{NaCl}$ disponiveis na literatura, mostraram fluidos originais com densidades variando principalmente entre 0,803 a 0,909 $\mathrm{g} / \mathrm{cm}^{3}$, a partir do qual foram construidas isócoras. Considerando-se nos diagramas isocóricos (P-T) a faixa mais freqüente de variação da Th $\left(245-265^{\circ} \mathrm{C}\right)$, foram determinadas pressöes de aprisionamento ao redor de 0,7Kbar. As pressões de aprisionamento das inclusões constituidas por água e metano não puderam ser estimadas.

As estimativas de pressão das inclusões carbônicas sin-deformacionais (grupo F - veios paralelos), foram realizadas a partir do cruzamento de isócoras com temperaturas obtidas a partir da interpretação dos padrões das tramas microestruturais e cristalográficas da amostra F45. A grande proporção de quartzo recristalizado dinamicamente neste veio (>70\%), aliado à grande concentração de eixo-c ao redor do eixo $Y$ (deslizamento prismático $<c>$ importante), além das condições mínimas de metamorfismo das rochas encaixantes (zona da granada), sugerem temperaturas de deformação de pelo menos $450-500^{\circ} \mathrm{C}$. Os cruzamentos dessas temperaturas com as isócoras representativas das inclusões carbônicas com densidades extremas (mínimas e máximas), forneceram pressões entre 1,5 e 2,1kbar (Fig. 10.17, Tabela 10.2). 


\subsubsection{Modelo de desenvolvimento dos veios}

Basicamente dois tipos de processos podem ser responsáveis pela imiscibilidade de fluidos: 1) resfriamento progressivo dos fluidos resultando em decréscimo da solubilidade do $\mathrm{CO}_{2}$ (comumente chamada de "boilling" retrógrado, Diamond, 1990); e 2) flutuação da pressão de fluidos durante a evolução do sistema de veios, causada pelos movimentos da falha (Sibson et al., 1975, 1988; Cox, 1995; Robert et al., 1995).

$O$ processo de boiling retrógrado conforme definido por Roedder (1984) e Diamond (1990), necessita de um substancial decréscimo da temperatura sem queda dramática da pressão de fluidos.

Na maioria dos veios da ZCR foram identificadas fortes evidências de ocorrencia de flutuação da pressão, registradas como diferentes densidades em inclusões do mesmo grupo.

Modelos propostos para explicar a flutuação na pressão de fluidos na formação de sistemas de veios incluem o de bombeamento sísmico (Sibson et al., 1975), o de faultvalve (Sibson et al., 1988) e o de desenvolvimento cíclico de veios de Robert et al (1995). Uma importante diferença entre esses modelos é que os dois primeiros foram elaborados para explicar uma única família de veio, enquanto o terceiro explica a relação contemporânea entre duas familias de veios com orientações diferentes, tais como os de cisalhamento e os extensionais. Outra diferença entre eles, é que os modelos de faultvalve e de desenvolvimento cíclico de veios consideram um sistema de falhas normais, enquanto o modelo de bombeamento sísmico foi desenvolvido para explicar veios associados com falhas transcorrentes. De qualquer modo, os três modelos essencialmente dependem de uma alta pressão de fluidos para desencadear eventos sísmicos, que resultam num decréscimo da pressão de fluidos devido à permeabilidade induzida pelo falhamento.

Segundo Cox (1995) em um sistema com um fornecimento constante de fluidos na base da zona de cisalhamento, inicialmente, após a ruptura, ocorre uma redução vagarosa da permeabilidade (pela precipitação de minerais e perda da pressão de fluidos), que resulta em um acréscimo gradual na pressão de fluidos antes da cicatrização da falha. Quando o fluxo de fluidos vai sendo progressivamente bloqueado pelo selamento da falha, pode ocorrer um rápido acúmulo de pressão de fluidos antes do selamento total das fraturas. Neste momento, uma movimentação sísmica na zona de cisalhamento produzirá dilatação em certas áreas e compactação em outras áreas. Nas áreas de dilatação, o brechamento das regiões anteriormente seladas produzirá um forte aumento da permeabilidade da zona de cisalhamento e, consequentemente, a pressão de fluidos pode decrescer repentinamente. 
Dos modelos propostos na literatura para o desenvolvimento de veios associados com zonas de cisalhamento (e.g. Sibson et al., 1975; Sibson et al., 1988, Robert et al, 1995; entre outros), somente o modelo de bombeamento sismico (Sibson et al., 1975) no qual é considerada uma falha transcorrente a geração dos sistemas de veios estudados neste trabalho.

Sendo a Zona de Cisalhamento Ribeira tipicamente de natureza transcorrente destral, com direção geral ENE, deveriamos esperar que os veios se formariam na direção do maior esforço principal $\left(\sigma_{1}\right)$, tendo, portanto, atitude NW/subvertical. Esse é justamente o padrão apresentado pelos veios extensionais (Fig. 10.18B). A presença de veios discordantes da foliação e com orientação NE, pode ser explicada como antigos veios extensionais rotacionados em sentido horário. A assimetria destral apresentada por esses veios corrobora com essa interpretação. Inicialmente essa poderia ser também uma explicação para a geração dos veios paralelos à foliação, visto que a orientação da foliação seria uma direção de compressão, improvável para aberturas. No entanto, muitos destes veios encontram-se praticamente indeformados, de modo deve existir outra explicação para suas gerações.

Uma hipótese provável de geração dos veios paralelos à foliação milonítica é a de que no rompimento da zona de cisalhamento, durante um sismo, esta se torna repentinamente permeável, induzindo a percolação dos fluidos expelidos da zona de dilatação e a precipitação de veios (Fig. 10,18).

\subsubsection{Possíveis fontes dos fluidos}

Diversas fontes devem ser consideradas na geração dos fluidos envolvidos na formação dos veios de quartzo sin-tectônicos, incluindo fluidos metamórficos gerados por devolatilização de rochas metassedimentares ou metabásicas, ou ainda provenientes da exalação de intrusões graniticas.

Os fluidos aquocarbônicos com salinidades moderadas a baixas, presentes em ambos sistemas de veios (paralelos e extensionais), são tipicamente semelhantes aos provenientes de fontes metamórficas, provavelmente relacionadas com devolatilização de rochas carbonáticas e/ou metabásicas. A abundância desses litotipos nas rochas encaixantes dos veios corrobora com essa interpretação.

Quanto as salmouras (grupo B) e inclusões moderadamente salinas (grupo E), podemos inicialmente considerar duas possiveis fontes: 1) devolatilização de metaevaporitos e 2) fontes magmática-hidrotermais. As evidências de campo são contrárias à primeira hipótese, visto que pelos dados levantados até o momento, as 
seqüências metavulcanossedimentares encaixantes dos veios säo tipicamente de mares relativamente profundos, não tendo sido identificados registros de metaevaporitos.

As evidências de campo também são inconclusivas quanto a uma origem magmática. Duas amostras apresentam inclusões de salmouras do grupo B (F45 e F254). A amostra F45 ocorre nas proximidades do batólito granítico Maciço de Itapeúna, e nesta localidade ocorrem veios pegmatíticos constituídos por feldspato, muscovita e quartzo, que poderiam sugerir contribuições magmáticas importantes. No entanto, a amostra F254, que se situa a $34 \mathrm{~km}$ de distância do corpo granítico mais próximo (o mesmo corpo), apresenta-se idêntica quanto ao número e características dos grupos de inclusões fluidas presentes, sugerindo que ambos os veios estão relacionados ao mesmo episódio de formação. Uma hipótese possivel, mas sem evidências diretas até 0 momento, é que a zona de cisaihamento intersecte fontes magmáticas em profundidade. Segundo Sibson et al. (1975) essa situação seria possivel se a área fonte dos fluidos for coincidente com a zona de dilatação.

De qualquer modo, estes fluidos são semelhantes àqueles identificados em algumas falhas ativas. Sibson et al. (1975) cita o exemplo da seqüência de terremotos Matsushiro (Hagiwara \& Iwate, 1968 apud Sibson et al., 1975), como resultado de movimentos transcorrentes, que fol acompanhada pela expulsão em superficie, em um ano, de aproximadamente $10^{10}$ litros de salmoura quente com $\mathrm{Na}-\mathrm{Ca}-\mathrm{Cl}$ e saturada em $\mathrm{CO}_{2}$ (Tsuneishi \& Nakamura, 1970, apud Sibson et al., 1975).

Por outro lado, a fonte metamórfica das salmouras não pode ser completamente descartada. Touret (1985) observou que inclusões fluidas hipersalinas são mais abundantes em mármores, metapelitos e rochas metavulcânicas do terreno granulítico Bamble, em relação aos ortognaisses da mesma região.

Outra possibilidade seria termos uma mesma fonte para os fluidos aquocarbônicos pouco salinos e as salmouras. Neste caso, os fluidos carbônicos, aquocarbônicos e as salmouras do sistema $\mathrm{CaCl}_{2}-\mathrm{NaCl}-\mathrm{H}_{2} \mathrm{O}$ poderiam ter sido gerados a partir de um fluido homogêneo formado originalmente pela devolatilização de rochas carbonáticas, e separados em profundidade (imiscibilidade), antes da ascensão e cristalização dos veios. Essa hipótese poderia explicar a presença, tanto nos veios paralelos quanto nos extensionais, de inclusões carbônicas e aquocarbônicas primárias que foram rapidamente sucedidas por inclusões aquosas de salinidades altas a moderadas. Essa situação provavelmente estaria ligada a diferentes propriedades de infiltração entre os fluidos rico em $\mathrm{CO}_{2}$ e rico em água e sais, de forma que um deveria ultrapassar o outro durante a ascensão. Contra essa hipótese está o fato de que as salmouras comumente ultrapassam o $\mathrm{CO}_{2}$ na ascensão (e.g. Newton et al., 1998). 


\subsection{Conclusões}

As texturas dos veios sin-tectônicos mostram grandes contrastes de deformação plástica e evidências de que estágios de crescimento se alternaram com estágios de deformação, indicando estágios cíclicos repetitivos no desenvolvimento dos sistemas de veios.

De modo geral, deduziu-se que os fluidos primários presentes na geração dos veios de quartzo (paralelos e extensionais) seriam aquocarbônicos e aprisionados em condições subsalvus sob regimes de flutuação da pressão. Ambos os veios foram afetados por pulsos aquossalinos tardios ou posteriores às suas cristalizações. No caso dos veios paralelos tais pulsos produziram misturas parciais com os fluidos aquocarbônicos mais primitivos.

Variações locais na composição de fluidos em veios paralelos são exemplificados pela amostra $\mathrm{F} 49$ (fluidos constituidos por água e metano), que também apresenta feições texturais muito distintas. Essas diferenças refletem a existência de diferentes episódios de formação de veios, e confirmam a ciclicidade dos processos de falhamento sismico decorrentes de ativações da ZCR.

As diferentes temperaturas de aprisionamento de inclusões primárias estimadas entre os veios paralelos $\left(300^{\circ} \mathrm{C}\right.$ e $\left.360-380^{\circ} \mathrm{C}\right)$ e extensionais $\left(190-220^{\circ} \mathrm{C}\right)$, associadas aos diversos estágios de formação de inclusões fluidas em cada tipo de veio, indicam que os veios paralelos estão relacionados a etapas mais antigas de movimentação da ZCR.

Recorrências de ativações da ZCR são indicadas pelos vários pulsos aquossalinos posteriores a formação dos veios paralelos. As temperaturas de aprisionamento cada vez mais baixas das inclusões secundárias sugerem que tais recorrências se deram em niveis estruturais progressivamente mais rasos.

Quanto a evolução geral do fluxo de fluidos pela Zona de Cisalhamento Ribeira, nota-se que pulsos de fluidos aquocarbônicos primitivamente ricos em metano evoluem no sentido de perda deste componente, e de um pequeno enriquecimento em nitrogênio. Esses pulsos se alternaram no tempo com pulsos aquossalinos.

Inclusões carbônicas sin-deformacionais presentes em amostras intensamente milonitizadas (F42 e F208), exemplificam bem a importância da presença de fluidos na milonitização. Também indicam flutuação da pressão em suas gerações.

A integração dos dados petrográficos e de inclusões fluidas mostram claramente que existiram repetidos ciclos de migração de fluidos pela ZCR, desde niveis mais inferiores (veios hipotermais cristalizados entre 360 e $380^{\circ} \mathrm{C}$ - inclusões do grupo A) até niveis superiores, com aprisionamento de inclusões fluidas em temperaturas menores que $100^{\circ} \mathrm{C}$ (inclusões do grupo E3). 
As grandes variações de densidade, associadas a falta de evidências de modificações posteriores ao aprisionamento das inclusões, na maioria dos grupos identificados, indicam importantes flutuações da pressão, que corroboram com a interpretação de processos de bombeamento sismico como mecanismo responsável pelo transporte e pela redistribuição de fluidos durante a ativação de zonas de cisalhamento, com geração de veios associada.

As conclusões obtidas pelo estudo de inclusões fluidas mostram-se coerentes com o contexto evolutivo das zonas de cisalhamento deduzido por outras abordagens. Em que pese as distâncias relativamente longas entre os pontos amostrados, os ambientes deduzidos mostram-se bem consistentes. 


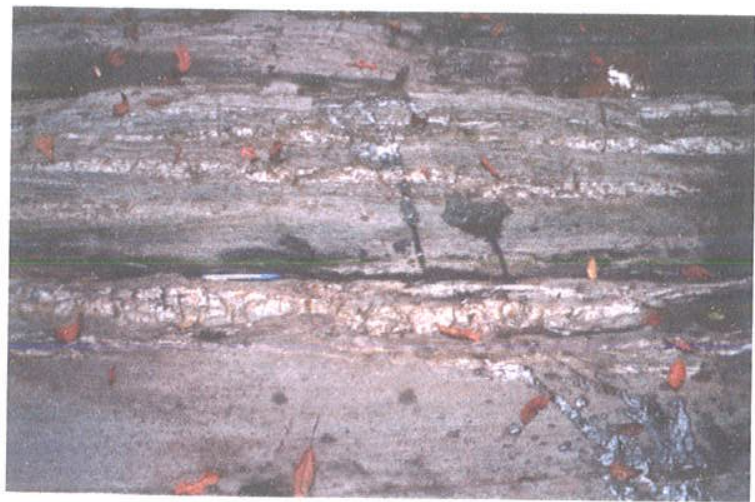

Figura 10.3A. Veio de quartzo paralelo à foliação milonítica.

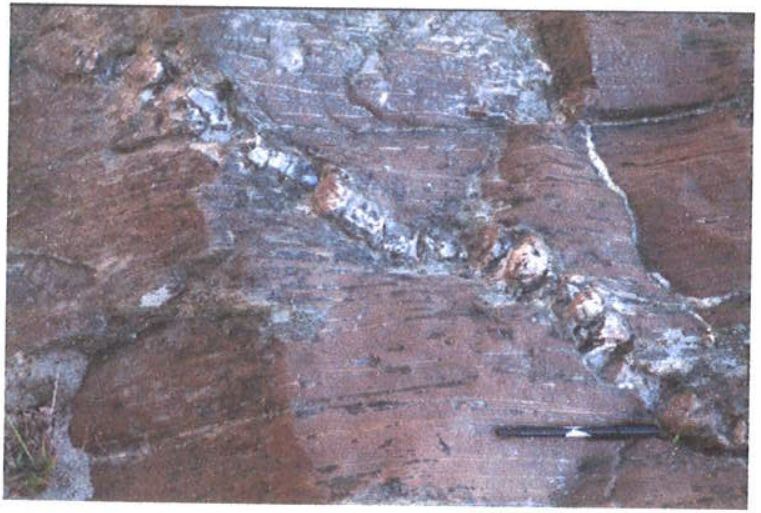

Figura 10.3B. Veio extensional de quartzo, com forma tabular, disposto a aproximadamente $45^{\circ}$ da foliação milonítica. Visão em planta.

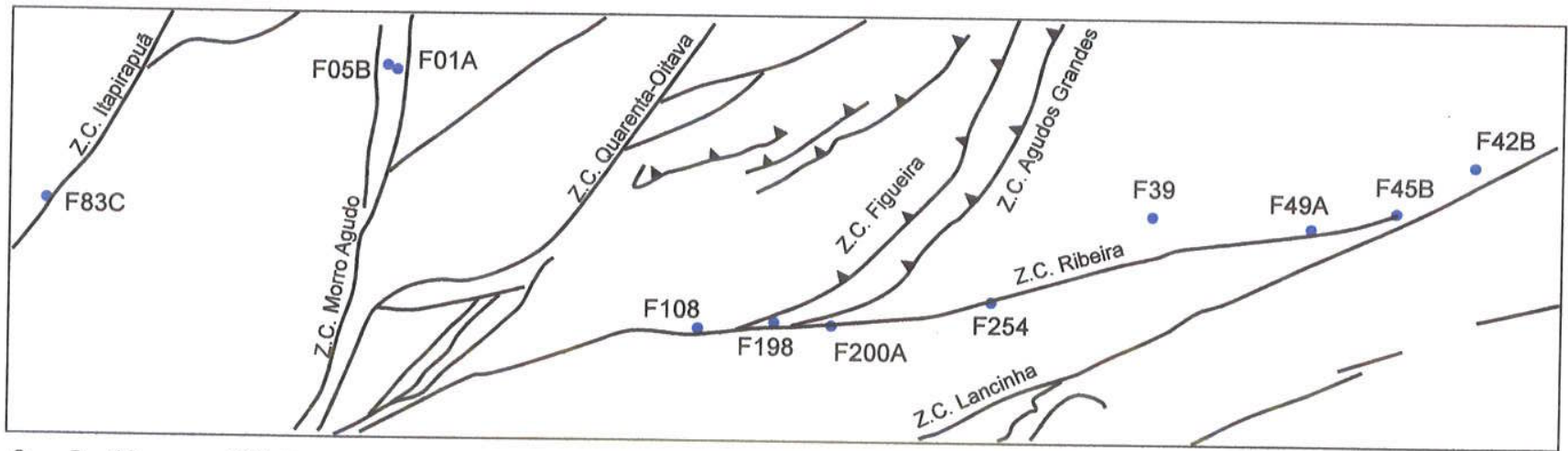

510 $20 \mathrm{~km}$

Figura 10.4. Localização das amostras de veios de quartzo estudadas. 
A

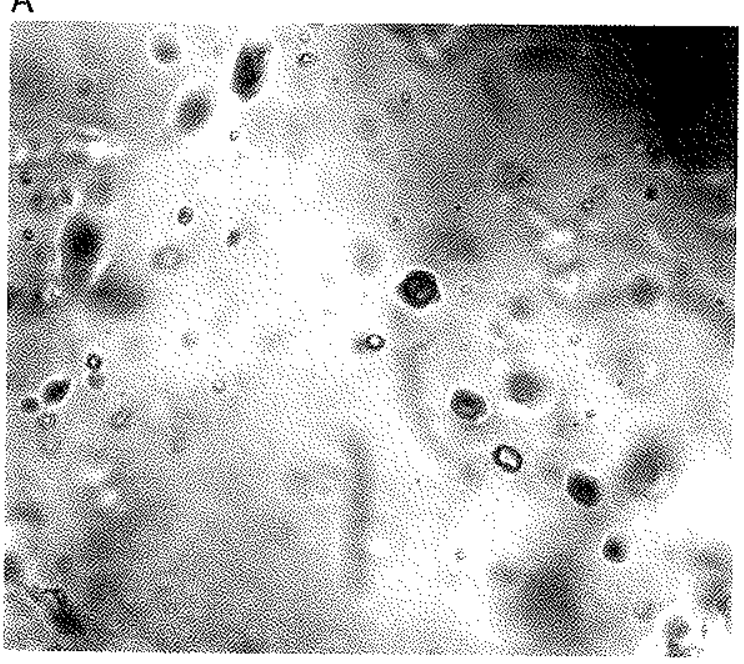

C
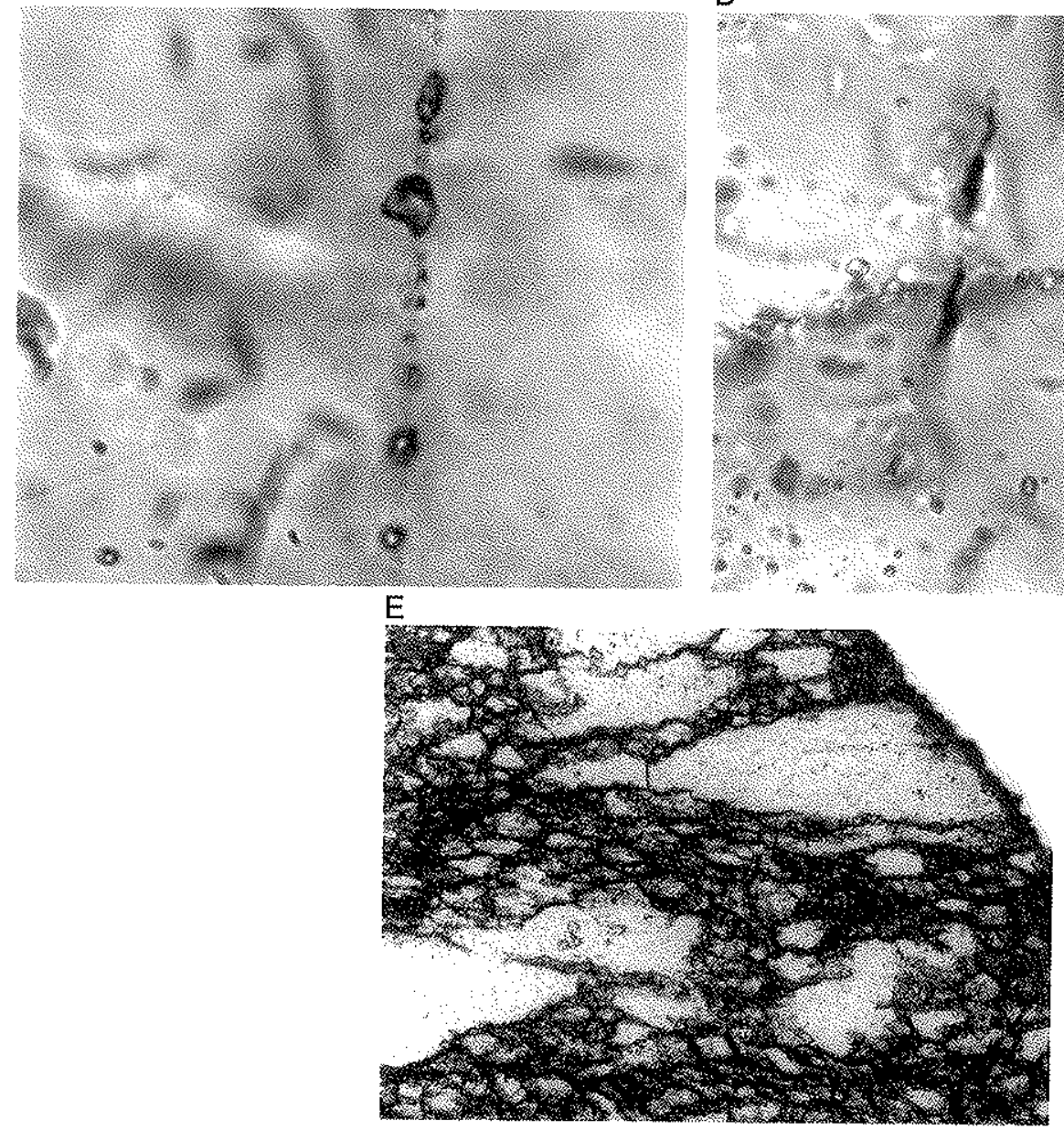

Figura 10.5. Fotomicrografias de inclusões fluidas nos veios paralelos. A) Inclusões carbônicas monofásicas e aquocarbônicas bifásicas associadas, grupo A. B) Inclusóes aquosas com sólidos de halita, grupo B. C) trilha formada por inclusões carbônicas e aquosas (fora do campo), grupo C. D) trilhas constituídas por inclusőes aquosas bifásicas tardias. E) amostra de veio de quartzo fortemente deformado. Notar tritha de inclusões carbônicas sin-deformacionais paralelas à foliação.

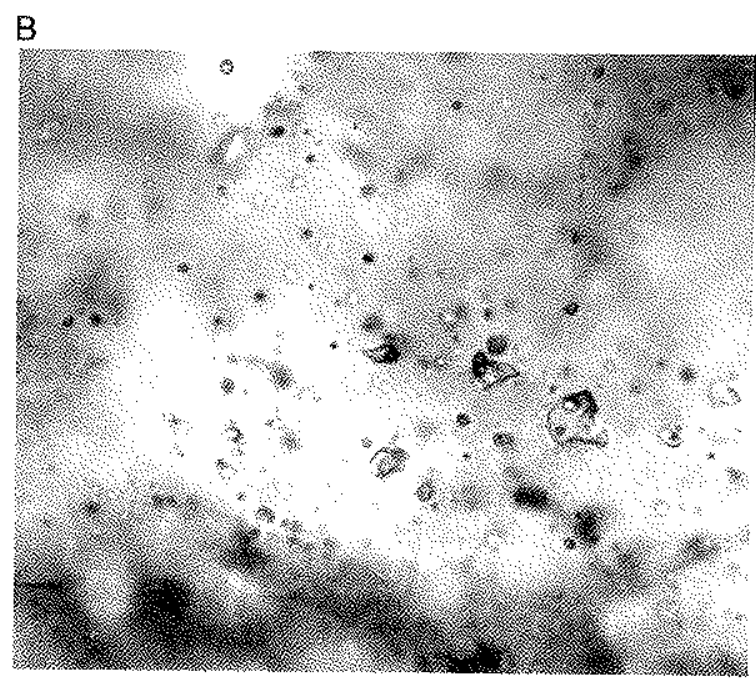

D

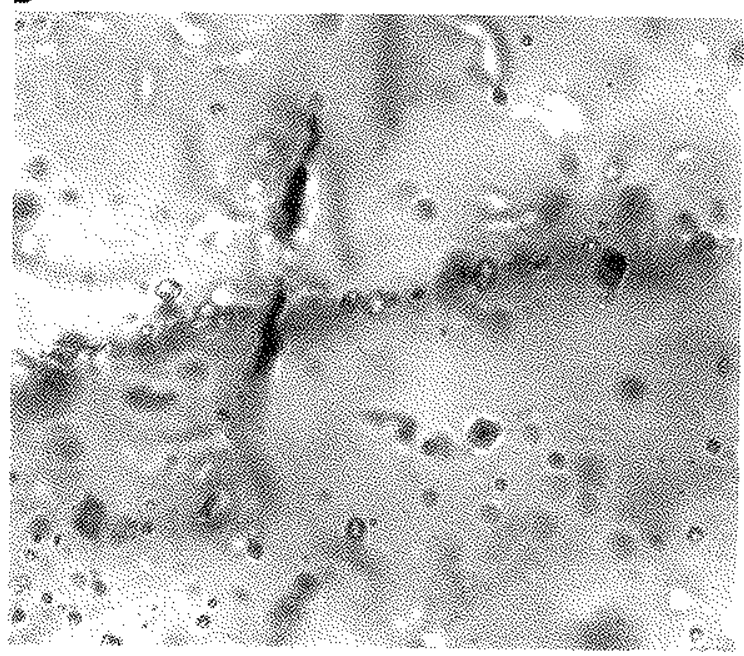



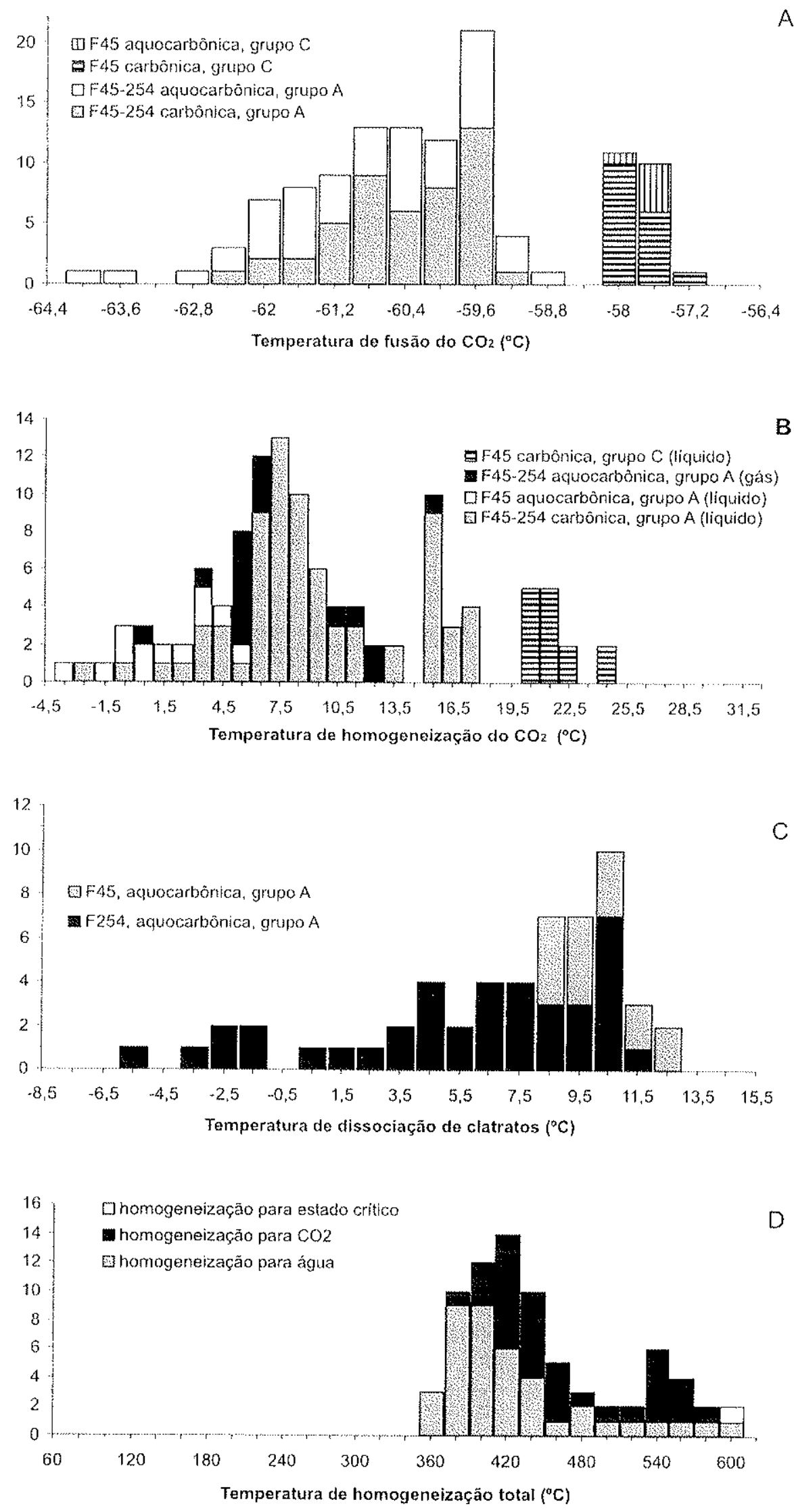

Figura 10.6. Histogramas com os resultados microtermométricos relativos às mudanças de fases em inclusões fluidas do grupo A presentes em veios paralelos a $5 \mathrm{~m}$. (A) Temperaturas de fusäo do $\mathrm{CO}_{2}$. (B) Temperaturas de homogeneização do $\mathrm{CO}_{2}$. (C) Temperaturas de dissociação de clataratos. (D) Temperaturas de homogeneização total. 

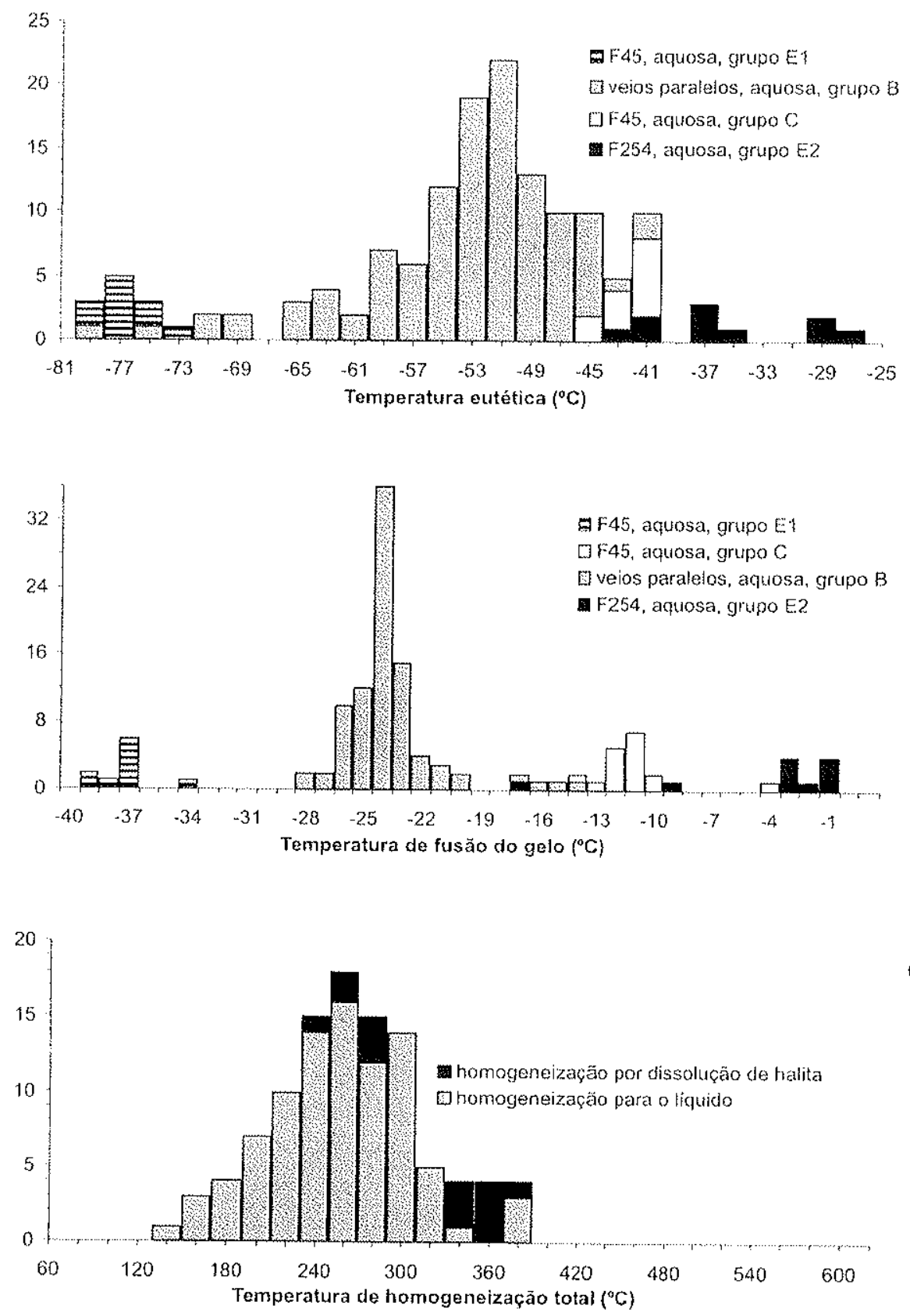

C

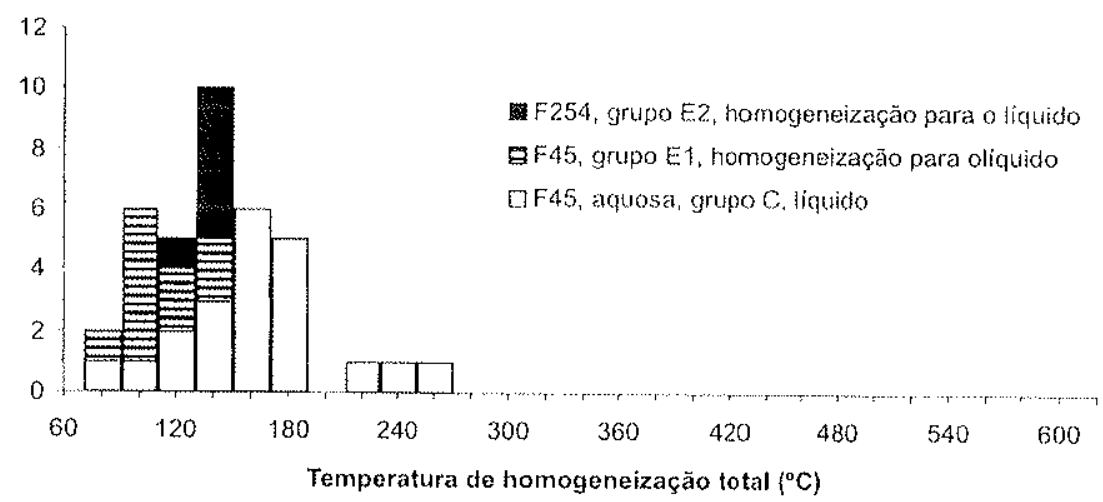

Figura 10.7. Histogramas com os resultado microtermométricos relativos às mudanças de fases em inclusöes aquosas primárias, pseudossecundárias e secundảrias. (A) Temperaturas eutéticas. (B) Temperaturas de fusão do gelo. (C e D) Temperaturas de homogeneização total. 


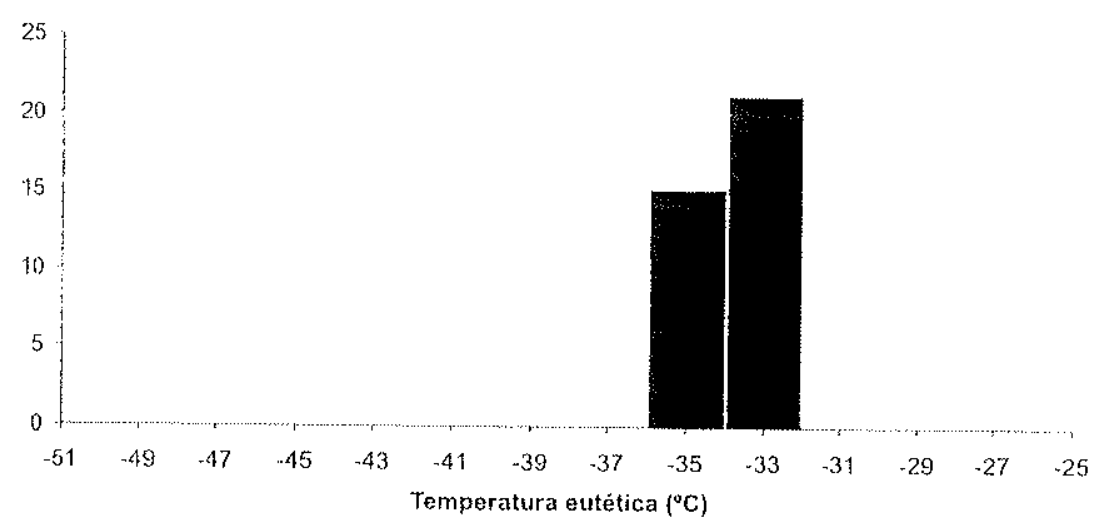

A

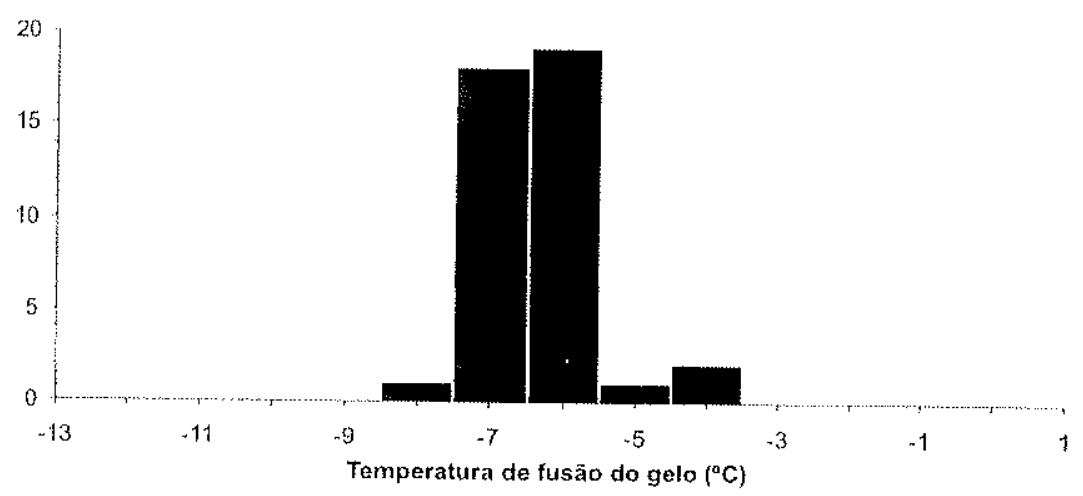

B
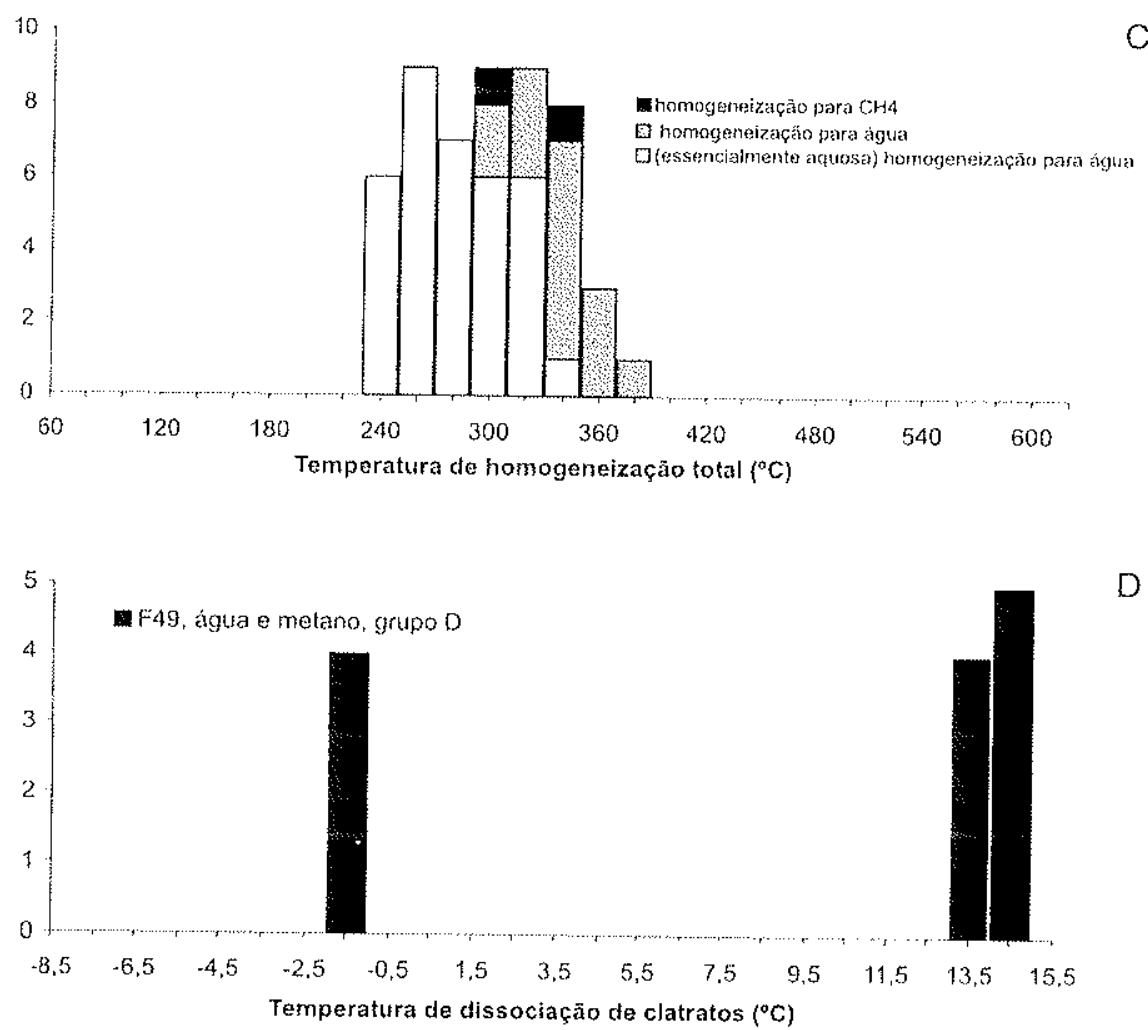

C

Figura 10.8. Histogramas com os resultados microtermométricos relativos às mudanças de fases em inclusôes fluidas do grupo $\mathrm{D}$ presentes em veios paralelos à $\mathrm{Sm}$. (A) Temperaturas eutéticas (essencialmente aquosas) (B) Temperaturas de fusão do gelo (essencialmente aquosas). (C) Temperaturas de homogeneização total. (D) Temperaturas de dissociação de clatratos (inclusões constituidas por $\mathrm{H}_{2} \mathrm{O}+\mathrm{C} \mathrm{H}_{4}$ ). 


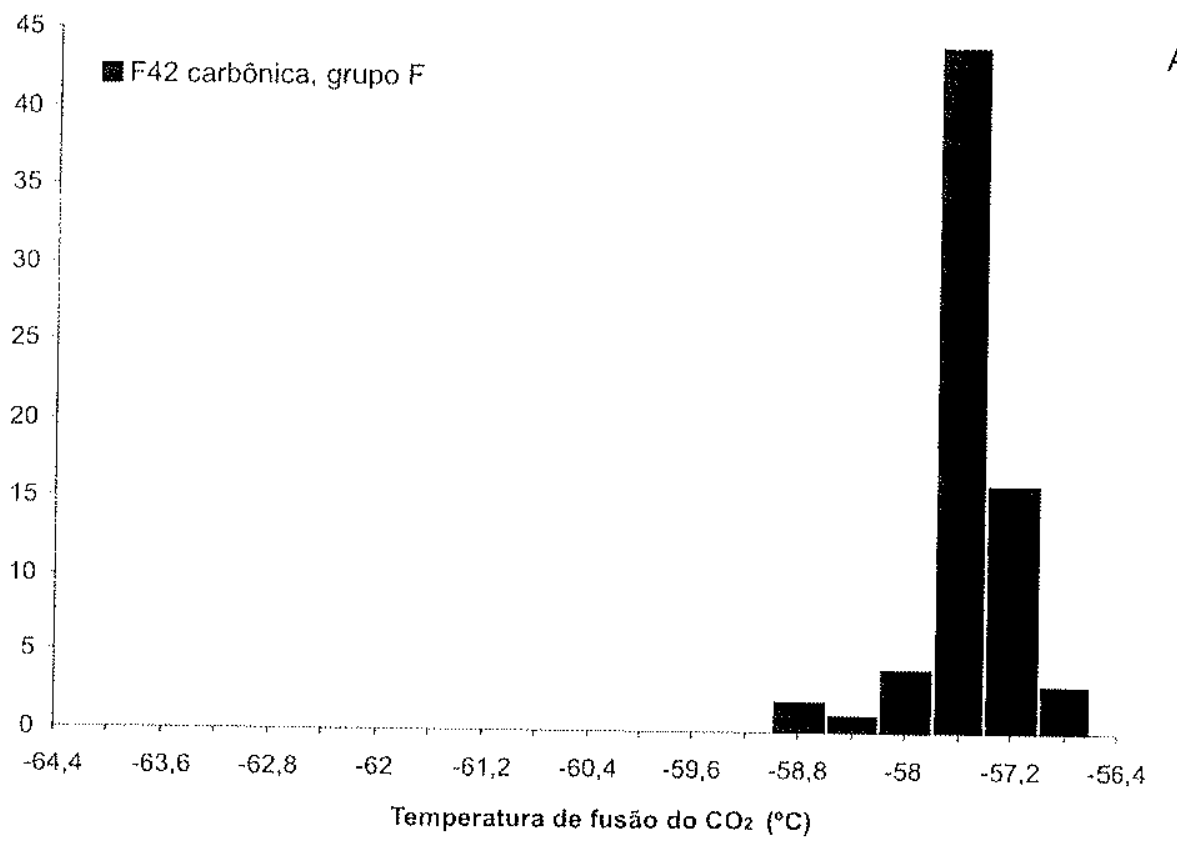

A

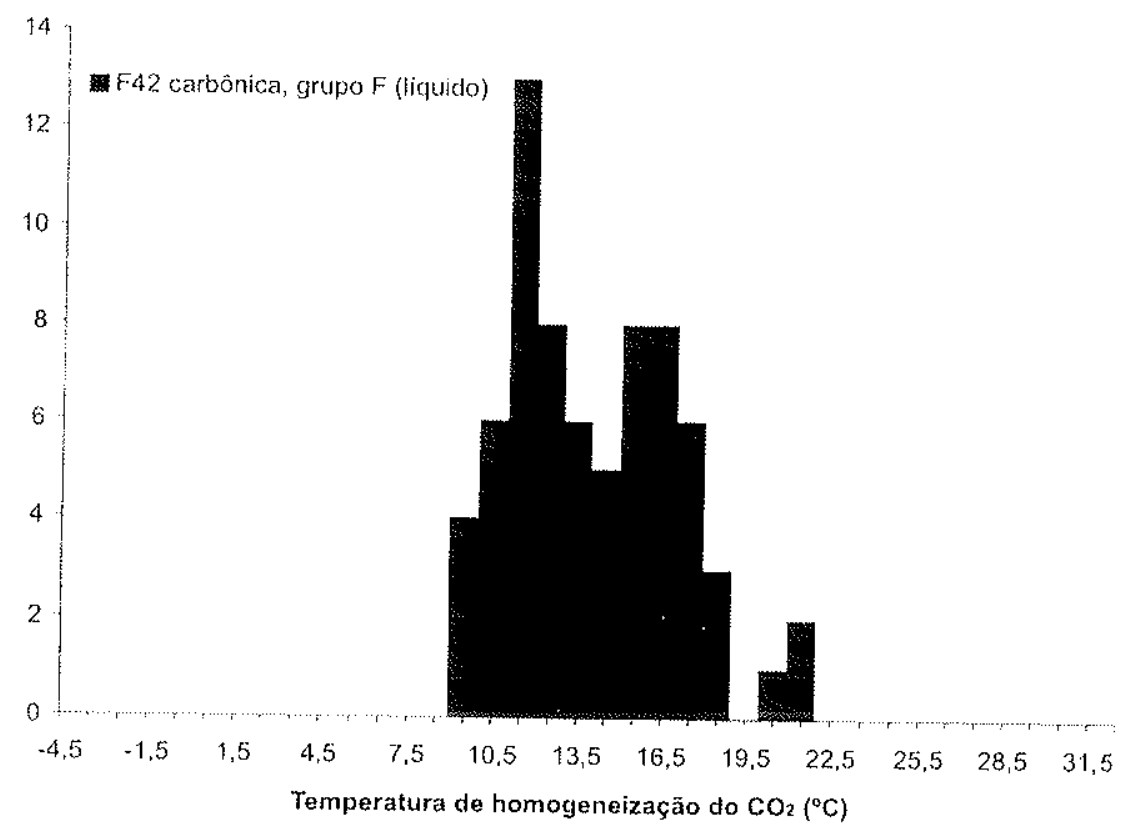

Figura 10.9. Histogramas com os resultados microtermométricos relativos às mudanças de fases em inclusões carbônicas do grupo f presentes em veios intensamente deformados e paralelos à foliação milonitica. (A) Temperaturas de fusão do $\mathrm{CO}_{2}$. (B) Temperaturas de homogeneização do $\mathrm{CO}_{2}$. 

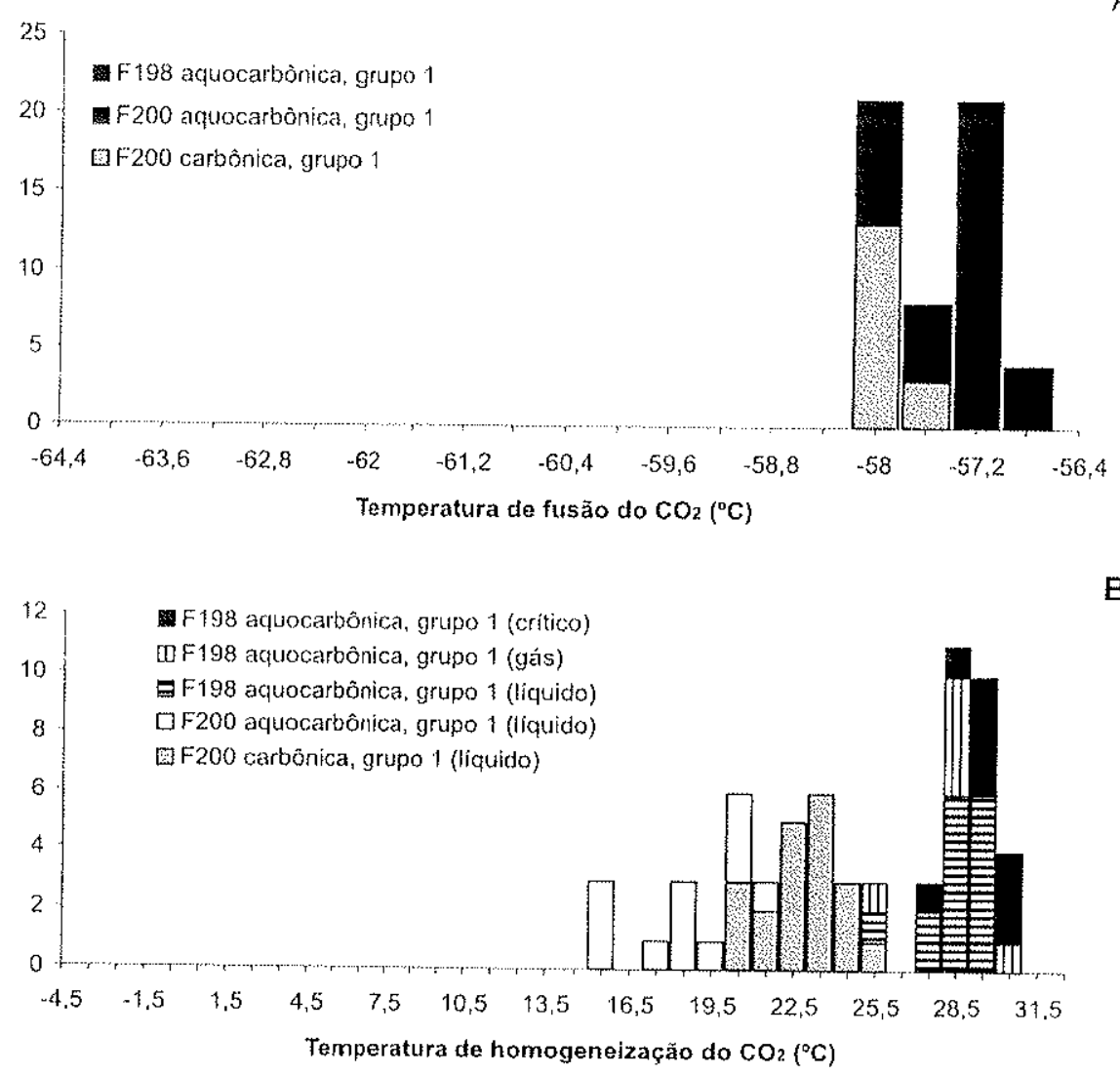

B

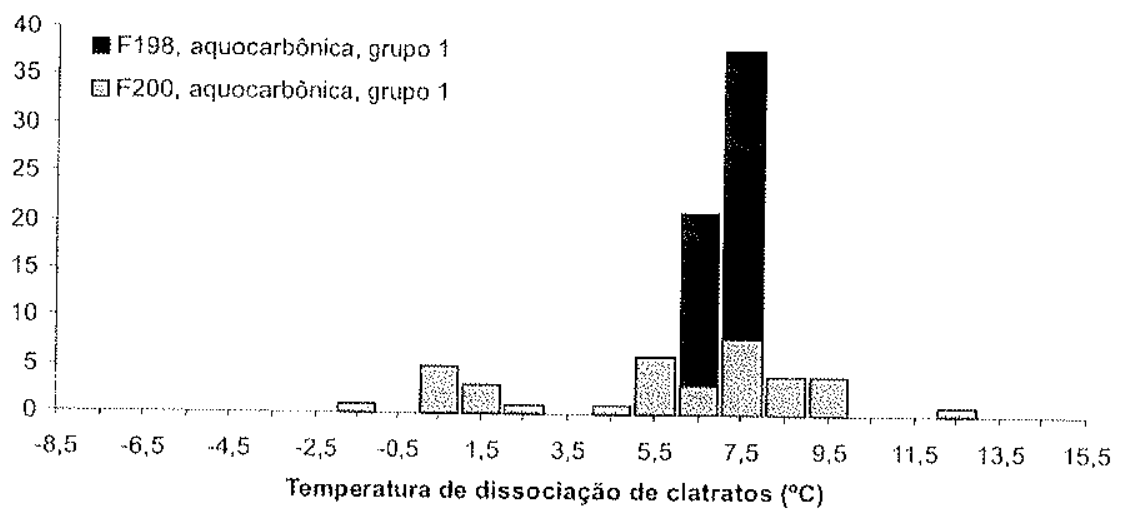

C

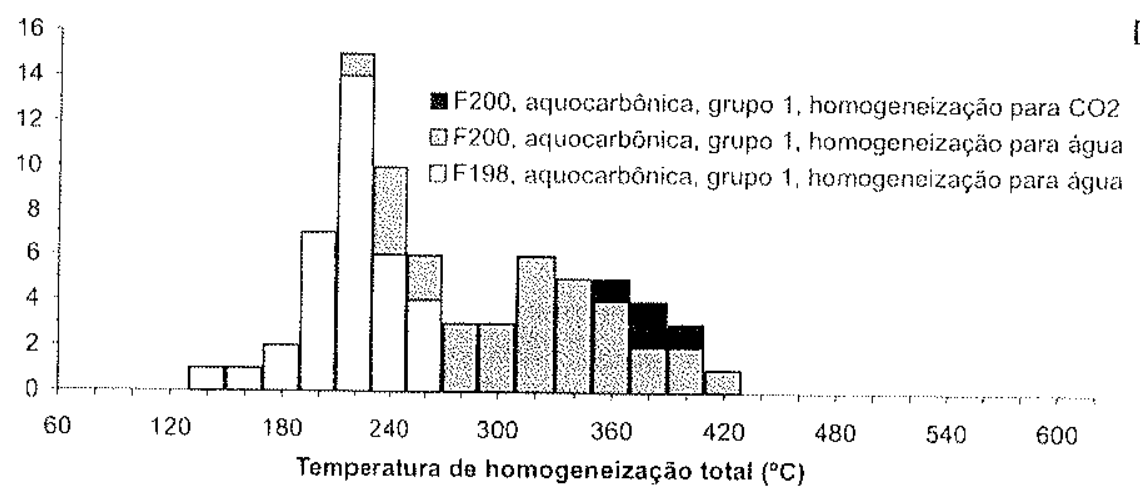

Figura 10.10. Histogramas com os resultados microtermométricos relativos às mudanças de fases em inclusöes fluidas do grupo 1 presentes em veios extensionais. (A) Temperaturas de fusão do $\mathrm{CO}_{2}$. (B) Temperaturas de homogeneização do $\mathrm{CO}_{2}$. (C) Temperaturas de dissociação de clataratos. (D) Temperaturas de homogeneização total. 

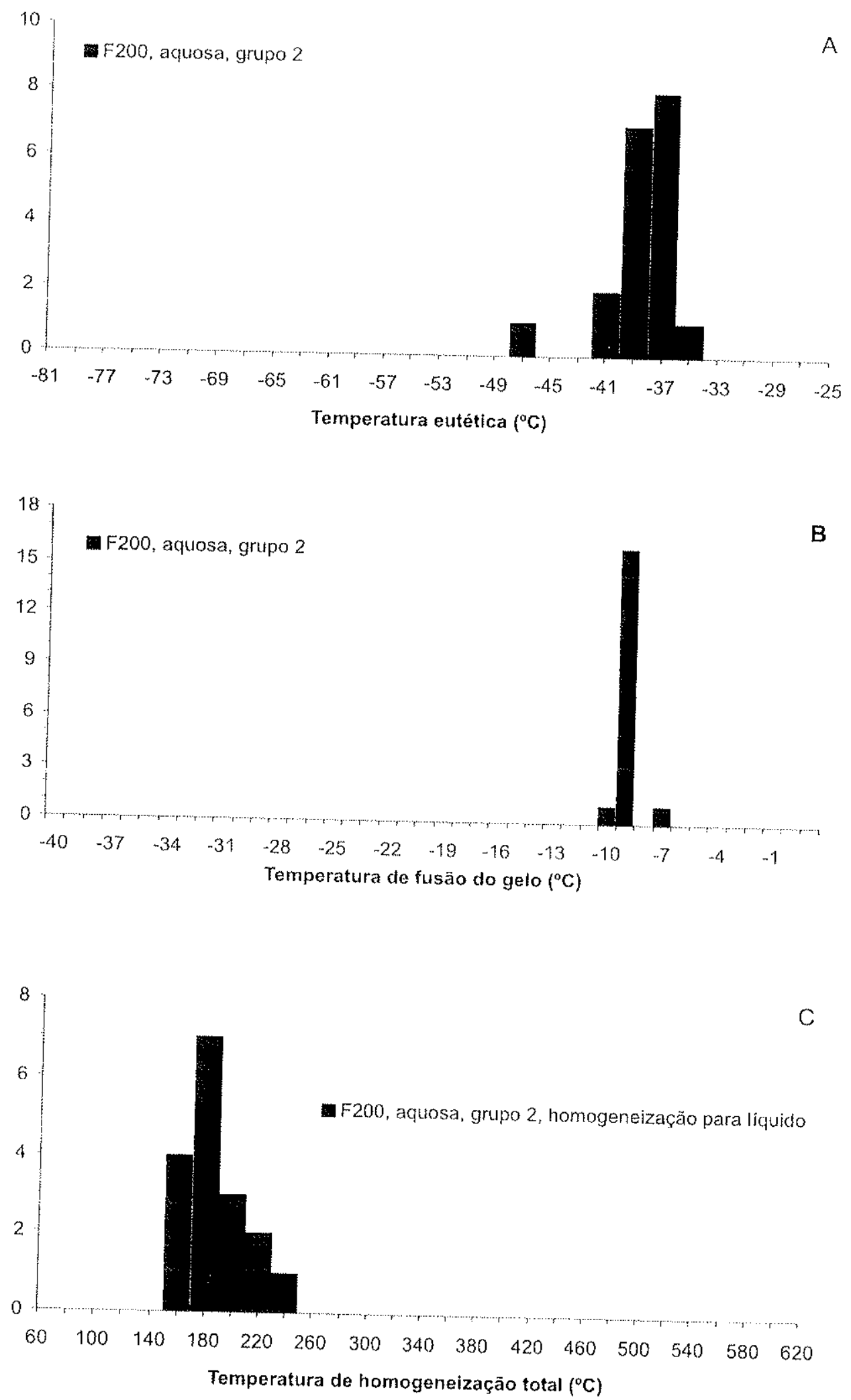

Figura 10.11. Histogramas com os resultados microtermométricos relativos às mudanças de fases em inclusões fluidas do grupo 2 presentes em veios extensionais. (A) Temperaturas eutéticas. (B) Temperaturas de fusão do gelo. (C) Temperaturas de homogeneização total. 

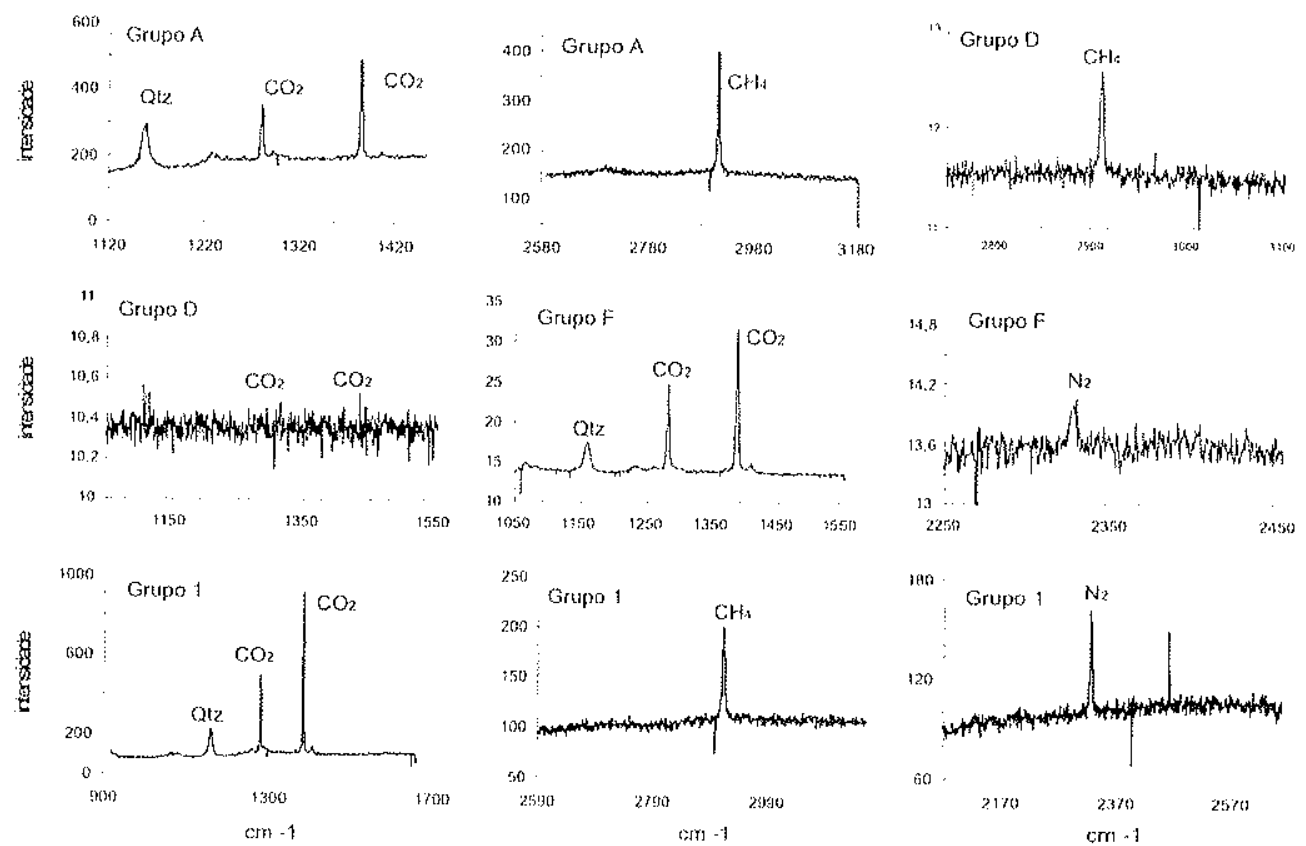

Figura 10.12. Espectros obtidos por espectroscopia Raman em inclusões fluidas carbônicas e aquocarbônicas dos grupos $A$ (primárias em veios paralelos), D (primárias em veios paralelos), $F$ (sin-deformacionais em veios paralelos intensamente milonitizados) e 1 (primárias em veios extensionais).
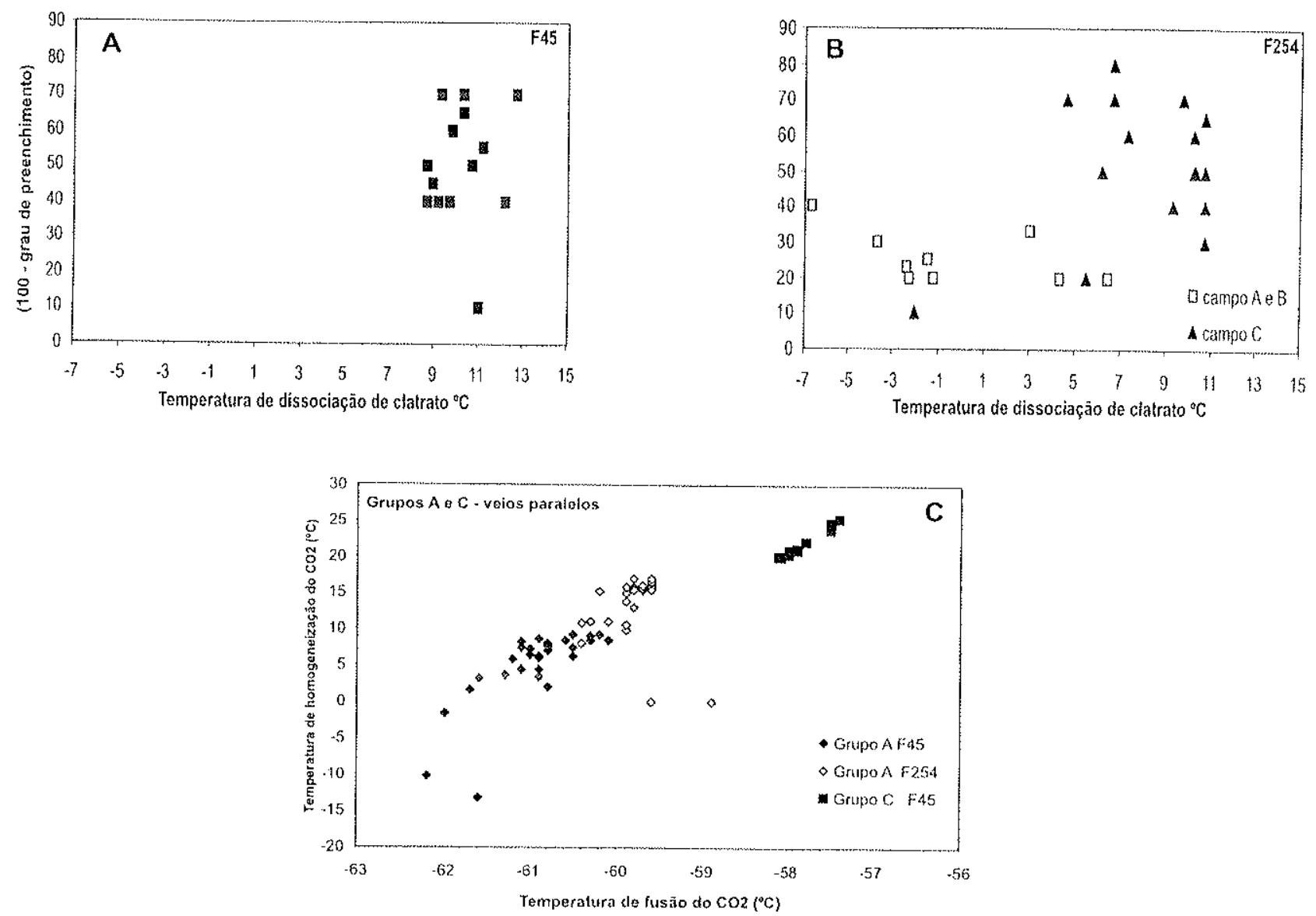

Figura 10.13. (A B) Diagramas relacionando temperaturas de dissociação de clatratos com grau de preenchimento para as inclusôes do grupo A presentes em diferentes amostras de veios paralelos à foliação milonítica.

(C) Diagrama relacionando temperaturas de fusão e homogeneização do $\mathrm{CO}_{2}$ para as inclusöes do grupo $\mathrm{A}$. 


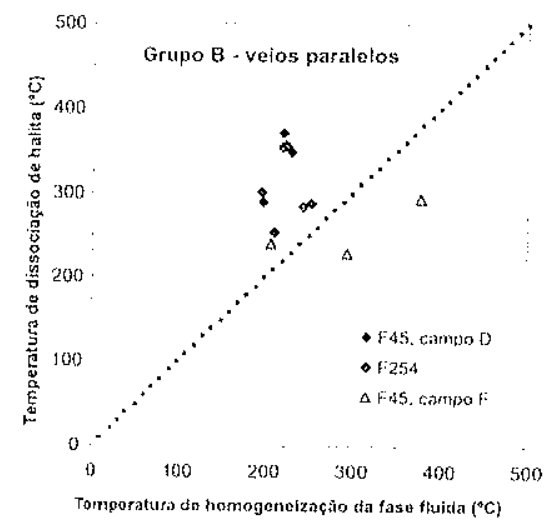

Figura 10.14. Diagrama relacionando temperaluras de homogeneização da fase fluidas e dissociação de sólidos. Inclusöes aquossalinas do grupo B, veios paralelos à foliação milonitica

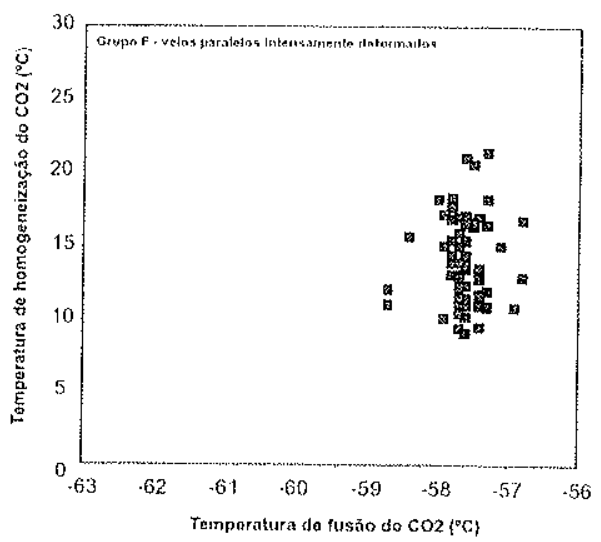

Figura 10.15. Diagrama relacionando temperaturas de homogeneização e fusão do $\mathrm{CO}_{2}$ para as inclusões carbônicas do grupo $F$, presente em veios intensamente deformados e paralelos à foliaçäo milonítica.
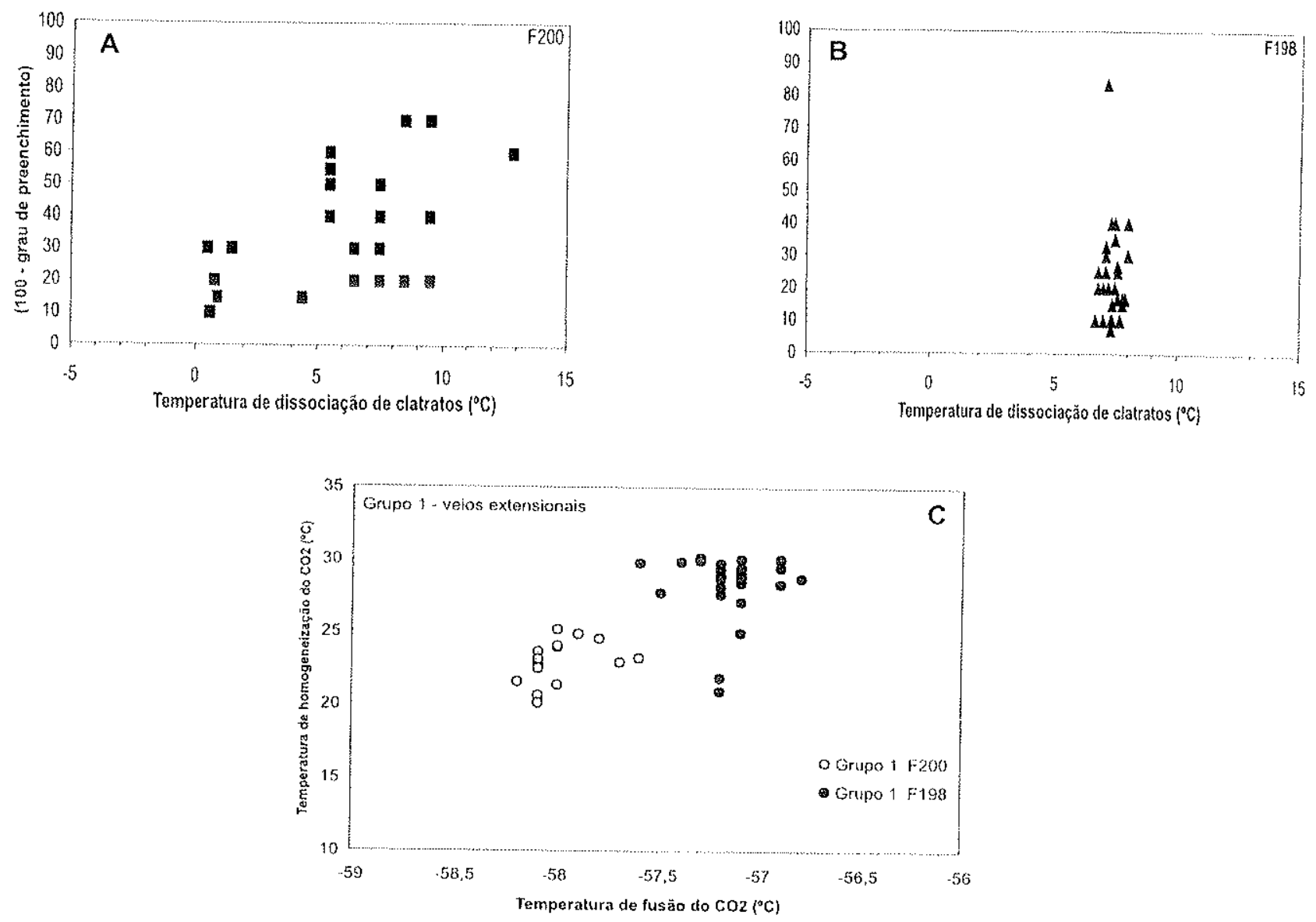

Figura 10.16. (A e B) Diagramas relacionando temperaturas de dissociação de clatratos com grau de preenchimento para as inclusões do grupo 1 presentes em diferentes amostras de veios extensionais.

(C) Diagrama relacionando temperaturas de fusão e homogeneização do $\mathrm{CO}_{2}$ para as inciusöes do grupo 1. 

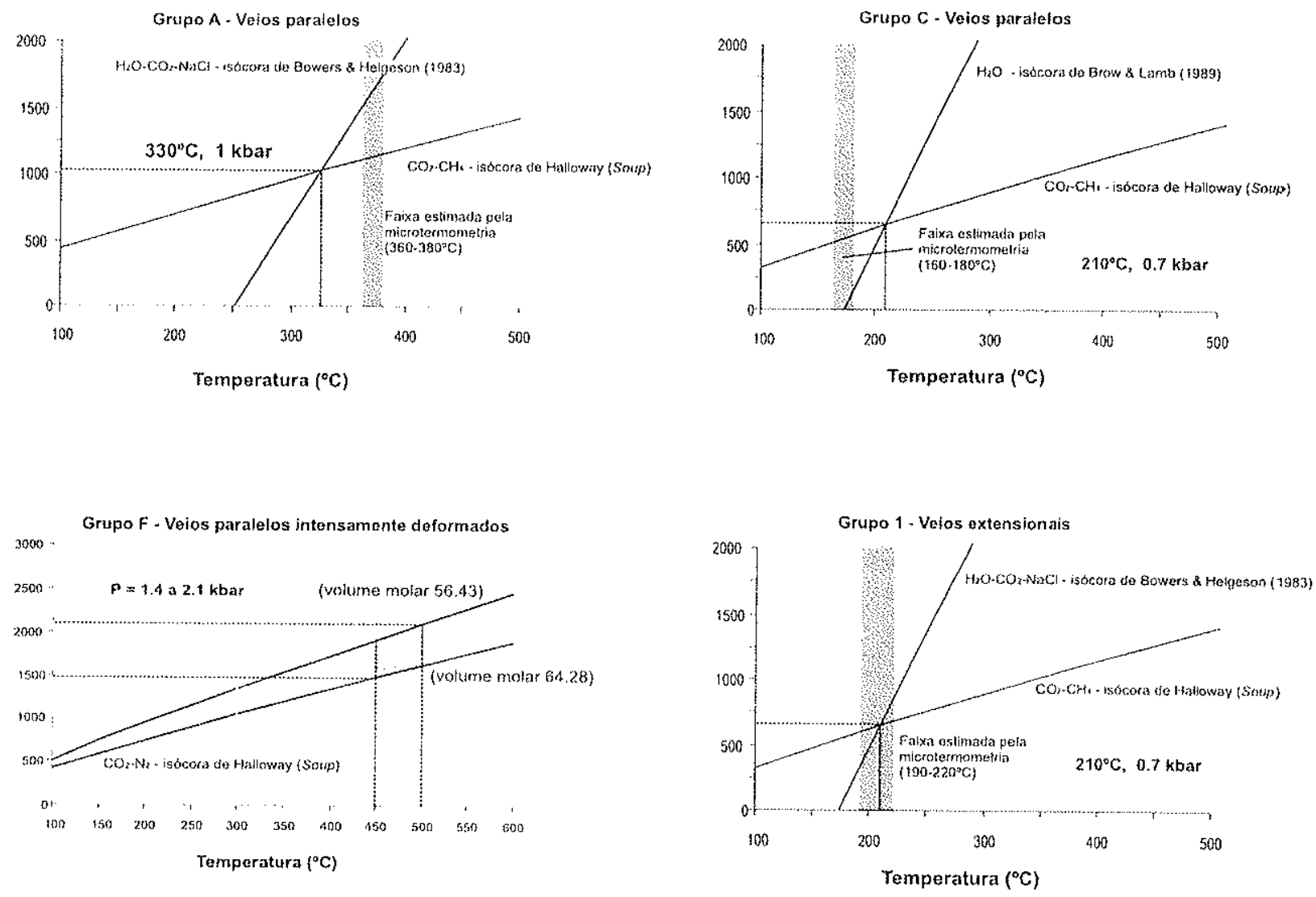

Figura 10.17. Estimativas de pressão de aprisionamento de inclusöes fíluidas pelos métodos do cruzamento entre isócoras (Grupos A, C e 1) e de isócoras com temperaturas estimadas por outro método (Grupo F) 
A

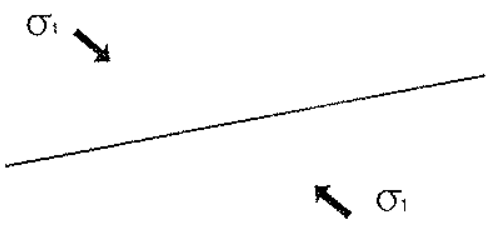

B

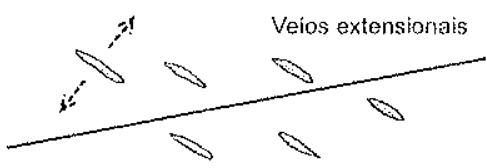

C

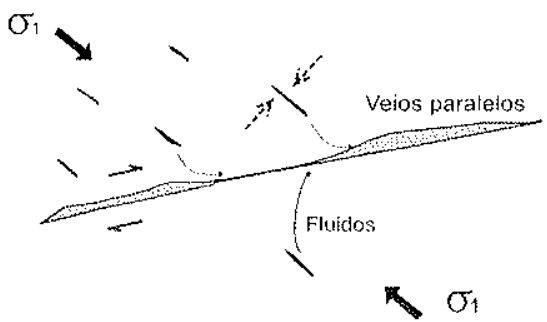

D

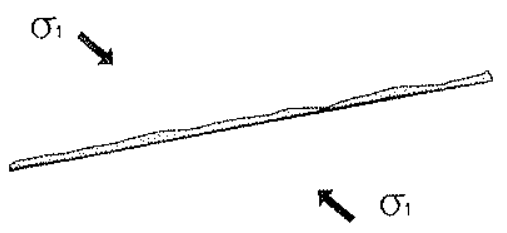

Inicial

Carregamento de tensöes

Falhamento e relaxamento das tensöes

Selamento da falha e novo carregamento das tensöes

Figura 10.18. Modelo alternativo de desenvolvimento dos veios paralelos à foliaçäo. 


\section{CONSIDERAÇÕES FINAIS}

\subsection{Evolução Metamórfica}

As estimativas de metamorfismo provenientes dos vários métodos utilizados (petrografia, microestrutural, tramas cristalográficas e inclusões fluidas) permitem reconhecer uma evolução polifásica da Zona de Cisalhamento Ribeira, desde niveis francamente dúcteis associado a metamorfismo em condições de fácies anfibolito até niveis relativamente rasos responsável pela geração de brechas tectônicas, veios de quartzo epitermais e inclusões fluidas secundárias de baixas temperaturas em fraturas cicatrizadas.

Apesar do caráter polifásico das deformações é possivel traçar um padrão de variação espacial, onde as rochas a norte dessa estrutura foram metamorfizadas em fácies xisto verde baixo, provavelmente em temperaturas inferiores a $400^{\circ} \mathrm{C}$, enquanto as rochas a sul foram metamorfizadas em condições mínimas de $500-520^{\circ} \mathrm{C}$ (metapelitos) e entre 500 e $600^{\circ} \mathrm{C}$ (metabasitos). As paragêneses da foliação milonítica $\left(S_{3}\right)$ mostram-se idênticas àquelas mostradas pelas rochas de ambos os blocos, norte e sul, sugerindo que a ZCR é responsável pela diferença de metamorfismo entre os dois blocos. Esse padräo pode facilmente ser explicado pela própria transcorrência. Considerando-se o rejeito direcional horário ao redor de $50 \mathrm{~km}$ calculado por Campanha \& Sadowski (2002), com uma lineação de estiramento caindo apenas $4^{\circ}$ para NE teriamos um rejeito vertical de aproximadamente $3,5 \mathrm{~km}$. Esse rejeito vertical deve ser o responsável pelo salto de no mínimo $150^{\circ} \mathrm{C}$ entre o metamorfismo dos blocos norte e sul. Ademais, as diferenças de metamorfismo e também do padrão estrutural poderiam ser explicadas como resultado da colagem de diferentes blocos, embora até o momento essa possibilidade não possa ser comprovada.

A rocha que apresentou o mais alto grau metamórfico determinado pela petrografia foi um metabasito situado no interior da ZCR. Nessa rocha a paragenese hornblenda + andesina (An 35-45), associada a completa ausência de clorita e a total recristalização dinâmica do plagioclásio, sugere condições metamórficas entre 550 e $600^{\circ} \mathrm{C}$, estando, portando, ligeiramente acima das condições de temperatura apresentadas pelas rochas encaixantes. A presença de porfiroclastos de anfibólio com núcleo de actinolita e borda de hornblenda e de hornblenda recristalizada na matriz milonítica indica que a milonitização se deu num dado momento com aumento da pressão e da temperatura. Um crescimento tardio de actinolita sobre as hornblendas. indica o inicio do retrometamorfismo, dado por queda da pressão e da temperatura. 
Os estudos das tramas cristalográficas de eixo-c de quartzo nas rochas de falha forneceram resultados compativeis com a análise petrográfica e microestrutural. As distribuições de eixos-c nas amostras estudadas indicam ativações principais dos sistemas de deslizamento basal <a> e romboédrico <a> na deformação do quartzo, porém com importantes contribuições do sistema prismático <a>. Essa situação sugere que as deformações ocorreram em temperaturas médias, de forma que devem estar associadas ao metamorfismo progressivo. Os padrões apresentados são coerentes com deformações entre 450 e $600^{\circ} \mathrm{C}$.

Uma trajetória de temperatura descendente é bem representada pelos vários grupos de inclusões fluidas presentes nos veios de quartzo. Inclusões carbônicas sindeformacionais presentes em veios intensamente deformados forneceram pressões entre 1,5 e 2,1 kbar considerando-se uma faixa de temperatura de deformação entre 450 e $500^{\circ} \mathrm{C}$ interpretadas a partir das microestruturas e das tramas cristalográficas na mesma amostra.

Inclusões primárias em veios de quartzo paralelos à foliação milonítica foram geradas em condições de $360-380^{\circ} \mathrm{C} / 1 \mathrm{kbar}$ e $300^{\circ} \mathrm{C}$.

Estágios posteriores de movimentação da ZCR são exemplificados pelas inclusões fluidas secundárias nos veios paralelos e pelos veios extensionais. Nos veios paralelos foram identificados grupos de inclusões fluidas secundárias presentes em trilhas distintas (fraturas cicatrizadas) geradas em condições de $250-270^{\circ} \mathrm{C}, 245$ $265^{\circ} \mathrm{C} / 0,7 \mathrm{kbar}, 160-180^{\circ} \mathrm{C} / 0,7 \mathrm{kbar}, 110-150^{\circ} \mathrm{C}$ e $85-143^{\circ} \mathrm{C}$, refletindo que a $\mathrm{ZCR}$ atuou em niveis progressivamente mais rasos.

Nos veios extensionais foram identificados apenas dois grupos de inclusões fluidas sendo um de inclusões primárias geradas em 190-220 $\mathrm{C} / 0,7 \mathrm{kbar}$ e outro de inclusões secundárias geradas entre 155 e $210^{\circ} \mathrm{C}$.

A integração dos dados sobre o metamorfismo e inclusões fluidas permitiu construir as trajetórias, em parte especulativas, mostradas na figura 11.1. Nenhuma das paragêneses reconhecidas na área de estudos é conclusiva quanto a pressão. No entanto, a completa ausência de cianita, mesmo em rochas metassedimentares que aparentemente teriam composições adequadas para a formação desta, sugere valores de pressão inferiores a $4 \mathrm{kbar}$, considerando as reações dos polimórfos de $\mathrm{Al}_{2} \mathrm{SiO}_{5}$ presentes na bibliografia. A trajetória de descida da temperatura apontada pelo estudo de inclusões fluidas mostra uma queda brusca desta sem grande variação da pressão. 


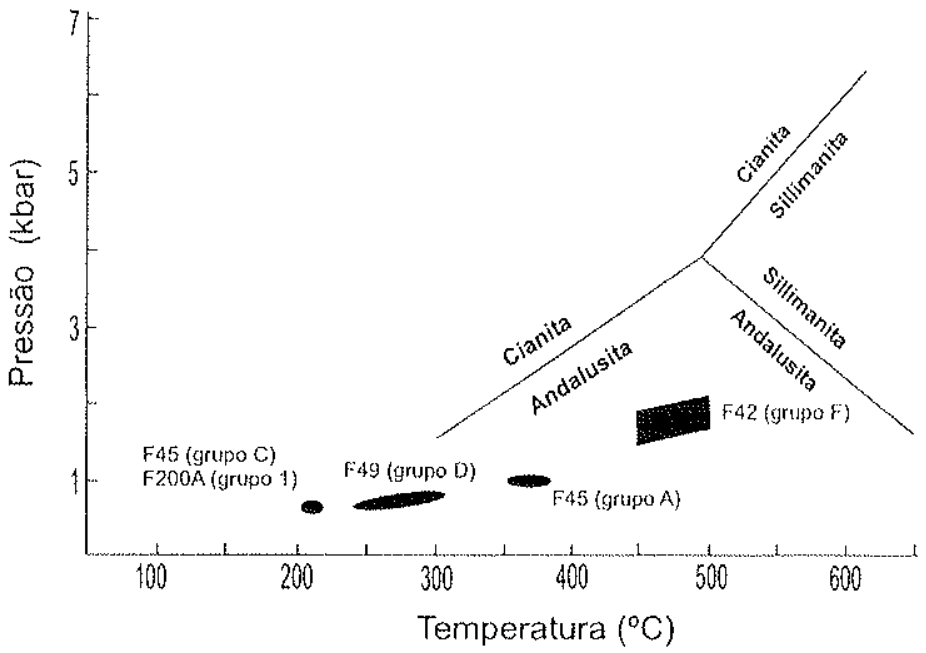

A

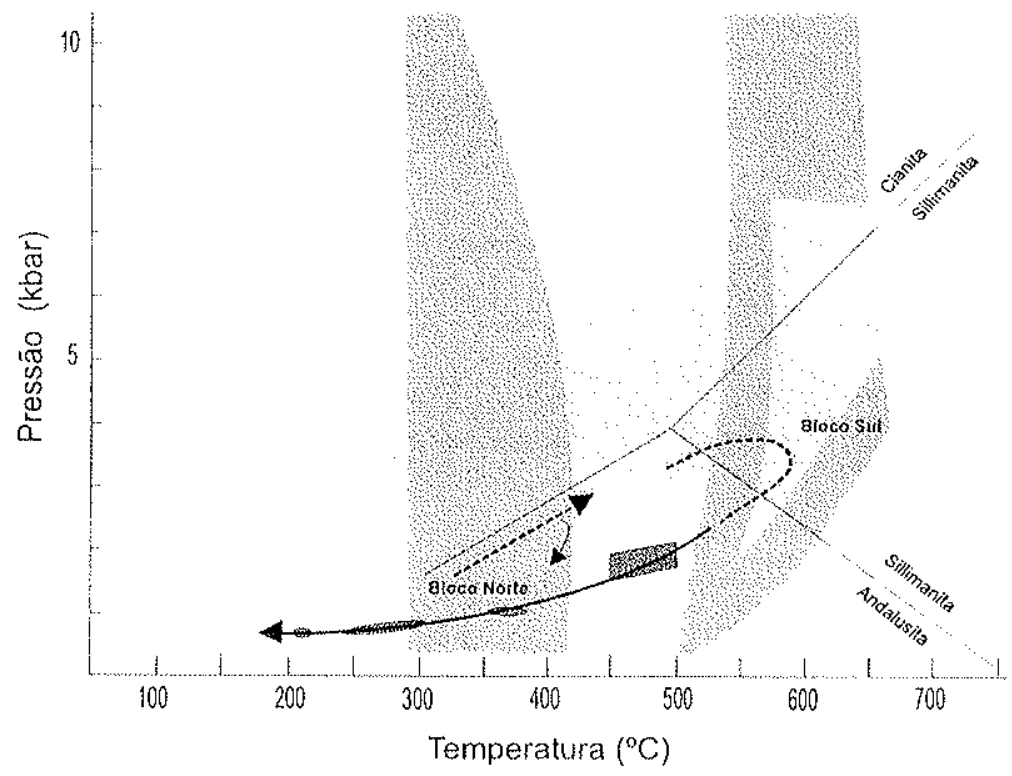

Figura 11.1. A) Campos de $P$ e $T$ estimados a partir das análises em inclusões fluidas. à trajetória obtida a partir da integração das estimativas de PT em inclusões fluidas.

B) Diagrama PT com os campos de estabilidade prováveis para as paragêneses relacionadas com cada foliação metamórfica e provável trajetória metamórfica. As linhas tracejadas são trajetórias interpretadas a partir das paragêneses metamórficas. A linha cheia corresponde à trajetória obtida a partir da integração das estimativas de PT em inclusões fluidas. 


\subsection{Evolução Cinemática}

Abaixo são discriminadas as principais evidências deformacionais do sistema de cisalhamento obtidas a partir dos vários métodos aplicados:

1) As estruturas defletidas ao redor da Zona de Cisalhamento Ribeira chegam a fazer ângulos de até $60^{\circ} \mathrm{com}$ esta estrutura. Segundo os modelos clássicos de cisalhamento simples (Ramsay \& Graham, 1970) e de transpressão (e.g. Sanderson \& Marchini, 1984; Robin \& Cruden, 1994; Tikoff \& Tessier, 1994) esse padrão não poderia representar foliações geradas concomitantemente com a zona de cisalhamento, uma vez que nestes casos os ângulos iniciais deveriam ser de no máximo $45^{\circ}$ no primeiro modelo, e menores que $45^{\circ}$ nos demais. Dessa forma é provável que as foliações e zonas de cisalhamento presentes, principalmente nos blocos a norte da ZCR sejam anteriores à geração desta.

2) O padrão de isógonas mostra uma clara interferência entre duas familias principais de estruturas tectônicas com orientações a grosso modo NE-SW e ENE-WSW. Às primeiras estruturas estariam associadas uma xistosidade de transposição intensa $\left(S_{1}\right)$ no Bloco Rio das Pedras, eixos de dobras regionais e foliação plano-axial empinada no Bloco Lajeado e falhas inversas tais como as zonas de cisalhamento Figueira, Agudos Grandes e Barra do Batatal. Como representante principal das estruturas da família ENE-WSW temos a ZCR e foliações associadas. O padrão de interferência entre as duas famílias de estruturas indica que as zonas de cisalhamento NE-SW, a princípio anteriores à ZCR, foram reativadas como falhas direcionais ou obliquas sinistrais.

3) A Zona de Cisalhamento Lancinha, tida como a principal estrutura do cinturão de cisalhamento transcorrente na área, corta todas as outras falhas sugerindo uma importante movimentação tardia em relação as outras estruturas. Corrobora com essa interpretação suas caracteristicas de campo, que mostram larguras muito restritas em relação à ZCR.

4) O padrão estrutural e metamórfico das unidades tectônicas ocorrentes a sul da Zona de Cisalhamento Lancinha é totalmente diverso, onde ocorrem foliações predominantemente de baixo ângulo, em alguns domínios com orientação NW, zonas 
de cisalhamento transcorrentes sinistrais e a presença de rochas metamorfizadas em grau mais alto, entre outras evidências.

5) As lineações de estiramento associadas à ZCR são predominantemente subhorizontais. No caso das zonas de cisalhamento NE-SW ocorrem lineações que variam desde máximo mergulho até obliquas com baixo caimento. Esse padrão foi comprovado também pelos eixos $X$ dos elipsóides de deformação finita $e$, atesta contra a aplicação dos modelos de transpressão de Sanderson \& Marchini (1984) e Tikoff \& Teyssier (1994) onde as lineações deveriam ser horizontais quando a transcorrência é dominante e de máximo mergulho na predominância de movimentos verticais, entretanto, nunca sendo oblíquas.

6) As formas dos elipsóides de deformação obtidos são tanto prolatas, como oblatas e próximas do tipo com $K=1$. Apesar da pequena quantidade de dados, é possivel traçar uma certa variação espacial entre esses tipos de elipsóides. A única trama obtida no Bloco Serra da Bandeira é prolata e, esse padrão é também sugerido pelas tramas fortemente lineares observadas em campo e pelas tramas cristalográficas de eixo-c em guirlandas cruzadas do tipo II, geralmente associadas a elipsóides prolatos. Elipsóides oblatos ocorrem somente na região de interação entre as zonas de cisalhamento Ribeira e Figueira, onde também situa-se a borda leste do maciço de Itaoca. Esse domínio é justamente aquele onde ocorrem lineações de estiramento de alto ângulo na faixa da ZCR. Portanto, é bem provável que aí ocorra intensa superposição de deformações. Ademais, os elipsóides do tipo com $\mathrm{K}=1$ parecem ocorrer onde dominam deformações da ZCR, no interior dos blocos tectônicos ou onde dominam as deformações das falhas da familia NE-SW.

7) Apesar da relativamente pequena variação da deformação máxima dada pela razão entre os valores dos eixos $X$ e $Z$, observa-se que a deformação é tipicamente heterogênea aumentando em direção às zonas de cisalhamento, conforme observado neste trabalho, por Campanha (1991) e Campanha \& Sadowski (2002).

8) Os indicadores cinemáticos das zonas de cisalhamento Ribeira e Lancinha são sistematicamente destrais, enquanto nas zonas de cisalhamento Figueira, Agudos Grandes e Barra do Batatal, parecem indicar componentes direcionais anti-horários.

Em vista de todas as evidências expostas acima o modelo teórico que melhor explica o desenvolvimento do sistema de cisalhamento presente na área é o de Merle \& 
Gapais (1997). Nesse modelo, os autores montaram uma equação matricial que combina cisalhamento simples transcorrente e cisalhamento simples de empurrão (ou normal). Os resultados são: elipsóides oblatos e prolatos quando se prescreve movimentos de empurrão e normais respectivamente; foliações e lineações bastante variadas com casos intermediários entre transcorrência e empurrões puros e presença de lineações oblíquas. Como esse modelo atende às prescrições de compatibilidade de strain (e.g. Ramsay \& Huber, 1987), são possiveis deformações heterogêneas.

Considerando-se os dados discutidos é possivel elaborar um modelo de evolução cinemática na qual todas as estruturas descritas seriam decorrentes de um único processo tectônico, provavelmente vinculado com uma convergência obliqua de placas (Fig. 11.2), seguindo a idéia inicial apresentada por Campanha (2002).

A partir de uma tensão máxima $\sigma_{1}$ de aproximadamente N55 W (direção perpendicular à orientação média das falhas $N E$ ), num primeiro momento teriam se formado, num estágio compressivo, empurrões e dobramentos de orientação NE-SW (Fig. 11.2A). A seguir instalar-se-ia um regime transcorrente, primeiramente com a geração das falhas ENE-WSW (Fig. 11.2B), cuja movimentação deslocaria as falhas NESW provocando ativações direcionais destas, que passariam a atuar como conjugados. Com a reativação direcional da porção sul da Zona de Cisalhamento Figueira, a Zona de Cisalhamento Morro Agudo seria gerada para compensar as movimentações (Fig. 11.2C). A etapa final seria representada pelos movimentos tardios controlados pelo cisalhamento paralelo à borda da placa, materializada pela Zona de Cisalhamento Lancinha (Fig. 11.2D).

Esse modelo diferencia-se daquele apresentado por Campanha (2002) pelas interpretações das reativações direcionais das falhas de empurrão e pelo significado da Zona de Cisalhamento Morro Agudo.

As reativações das falhas de empurrão são bem marcadas no padrão de isógonas, conforme discutido anteriormente.

Como suporte da hipótese de geração da Zona de Cisalhamento Morro Agudo podemos citar: (1) a natureza contraditória desta, tendo sido caracterizada como transcorrente (Fiori, 1985a, b; Campanha, 2002), transpressional (Kops et al., 1993) e como uma falha de empurrão na porção paranaense (e.g. Battola JR., 1977); (2) As diferenças de orientação da Zona de Cisalhamento Morro Agudo nos trechos a norte $\left(\sim \mathrm{N} 10^{\circ} \mathrm{E}\right)$ e a sul $\left(\sim \mathrm{N} 35^{\circ} \mathrm{E}\right)$ da Zona de Cisalhamento Ribeira; (3) Sua extremidade norte sugerindo padrões em rabo de cavalo típicos de terminações de Zonas de Cisalhamento. 

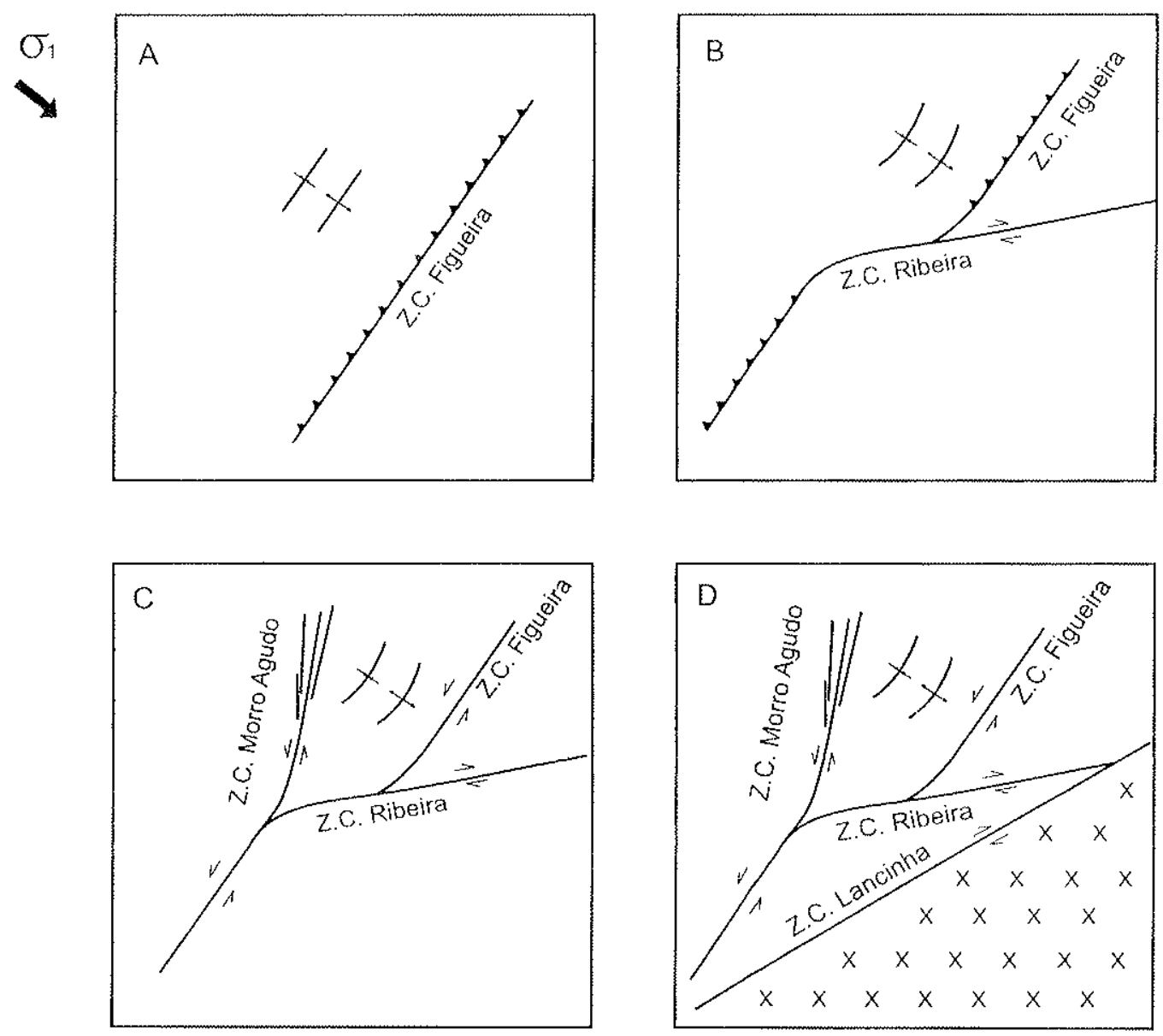

Figura 11.2. Modelo de evolução tectônica.
(A) episódio compressivo caracterizado por empurrões seguidos de dobramentos
(B) instalacação de regime transcorrente com geração das falhas ENE.
(C) reativaçăo direcional das falhas NE e geração das falhas transcorrentes NNE.
(D) movimentos tardios condicionados pela borda da placa. 


\section{CONCLUSÖES}

As diferenças estruturais e metamórficas entre os blocos separados pela Zona de Cisalhamento Ribeira indicam que esta é responsável pelo zonamento metamórfico do Supergrupo Açungui na região estudada. Esse zonamento pode ser explicado por uma transcorrência destral levemente oblíqua na qual o bloco a sul da ZCR teria sido alçado por alguns quilômetros em relação aos blocos a norte desta estrutura.

A presença lado a lado de rochas de falha com texturas contrastantes (e.g. brechas e ultramilonitos) reflete uma longa história deformacional da Zona de Cisalhamento Ribeira. Entretanto essas ocorrências podem ser, em parte, relacionadas com diferenças de competências entre as rochas e a atuação da pressão de fluidos (fraturamento hidráulico).

As evidências texturais apresentadas por anfibolitos miloníticos onde ocorre a substituição de actinolita por hornblenda indica que a milonitização se deu a princípio com aumento da pressão e temperatura, tendo alcançado condições de $550-600^{\circ} \mathrm{C}$ Posteriormente seguiu-se estágios de movimentação em niveis progressivamente mais rasos numa trajetória com forte decréscimo da temperatura sem grande decréscimo da pressão, conforme apontado pelas condições de aprisionamento de inclusões fluidas em veios de quartzo sin-tectônicos. Nos niveis mais rasos ocorreram deformações em temperaturas mínimas entre 85 e $150^{\circ} \mathrm{C}$, indicado por inclusões fluidas secundárias aprisionadas em fraturas cicatrizadas.

Os padrões de tramas de eixo-c de quartzo das rochas de falha são típicos daqueles gerados em temperaturas médias, de forma que devem estar registrando as etapas de metamorfismo progressivo. A variação espacial dos tipos de tramas observadas mostra uma clara associação destas com os diferentes niveis estruturais e/ou metamórficos, ou ainda relacionadas com o litotipo (proporção entre micas e quartzo).

As relações geométricas entre as diferentes familias de zonas de cisalhamento e foliações associadas indicam que uma trama NE, mais antiga, caracterizada por falhas de empurrão foi defletida por uma trama transcorrente destral ENE e reativada como falhas direcionais ou obliquas sinistrais atuando como conjugados destas últimas.

As relações angulares entre as zonas de cisalhamento das famillias NE e ENE aliadas aos padrões de distribuição espacial dos elipsóides de deformação e das foliações e lineações de estiramento associadas não favorecem a aplicação dos modelos transpressivos numa hipótese de geração concomitante destas estruturas. Dessa forma, os dados indicam que ocorreu superposição de deformações.

A distribuição espacial dos valores de deformação finita máxima mostra que estas crescem em direção às zonas de cisalhamento indicando deformações heterogêneas. 
A integração dos dados existentes sobre a história deformacional suportam a hipótese de uma evolução tectônica progressiva vinculada com convergência oblíqua entre placas, caracterizada por três estágios principais. Inicia-se um estágio compressivo no qual foram geradas falhas de empurrão e macrodobras de orientação NE. Segue-se a instalação de transcorrências com orientação ENE, reativações direcionais das falhas NE e geração de transcorrências NNE. O estágio final foi marcado pelos movimentos tardios controlados pelo cisalhamento paralelo à borda da placa, materializados pela Zona de Cisalhamento Lancinha.

A presença de veios de quartzo com diferentes geometrias e grupos de inclusões fluidas com características distintas sugere que esses foram gerados em diferentes estágios de movimentação da Zona de Cisalhamento Ribeira, em niveis progressivamente mais rasos. As texturas apresentadas pelos dois tipos principais de veios (extensionais e paralelos à foliação milonítica) mostram grandes contrastes de deformação plástica e evidências de que estágios de crescimento se alternaram com estágios de deformação. Esses dados indicam que os sistemas de veios foram desenvolvidos em estágios cíclicos repetitivos.

Ambos os tipos principais de veios de quartzo foram gerados na presença de fluidos primários aquocarbônicos aprisionados em condições subsolvus sob processos de flutuação da pressão. Em etapas tardias e posteriores a suas cristalizaçöes, ambos os tipos de veios foram submetidos a deformações acompanhadas de pulsos de percolação de fluidos aquossalinos, em niveis crustais progressivamente mais rasos.

As diferentes temperaturas de aprisionamento de inclusões primárias estimadas entre os veios paralelos $\left(300^{\circ} \mathrm{C}\right.$ e $\left.360-380^{\circ} \mathrm{C}\right)$ e extensionais $\left(190-220^{\circ} \mathrm{C}\right)$, associadas ao número de estágios de geração de inclusões fluidas identificadas em cada tipo de veio, indicam que os primeiros estão relacionados a etapas mais antigas de movimentação da ZCR.

Quanto a evolução geral do fluxo de fluidos pela Zona de Cisalhamento Ribeira, nota-se que pulsos de fluidos aquocarbônicos primitivamente ricos em metano evoluem no sentido de perda deste componente e de um pequeno enriquecimento em nitrogênio. Esses pulsos se alternaram no tempo com pulsos aquossalinos.

As grandes variações de densidade, associadas a falta de evidências de modificações posteriores ao aprisionamento das inclusões, na maioria dos grupos identificados, indicam importantes flutuações da pressão, que corroboram com a interpretação de processos de bombeamento sísmico como mecanismo responsável pelo transporte e redistribuição de fluidos durante a ativação de zonas de cisalhamento, com geração de veios associada. 


\section{REFERÊNCIAS BIBLIOGRÁFICAS}

ALGARTE, J. P. et al. 1974. Projeto Sudeste do Estado de São Paulo; relatório final. São Paulo, Convênio DNPM/CPRM.

ANDERSON, M.R.; RANKIN, A.H., SPIRO, B. 1992. Fluid mixing in the generation of mesothermal gold mineralization in the Transvaal Sequence, Transvaal, South Africa. Eur. J. Mineral. (4): 933-948.

APTED, M.J. \& LIOU, J.G. 1983. Phase relations among greenshist, epidote-amphibolite, and amphibolite in a basaltic system. Am. J. Sci (283): 328-353.

BARBOSA, O. 1941. Geologia e petrologia na região de Apiai, Estado de São Paulo. São Paulo, 76 p. (Tese para concurso da cadeira de "Geologia, Petrografia e Mineralogia". Escola Politécnica - USP) (inédito).

BARBOSA, O. 1948. A chamada Série Ribeira. São Paulo, Min. Metal. 13 (79): 187-189.

BIGARELLA, J.J. \& SALAMUNi, R. 1956a. Estudos Preliminares na Série Açungui. V. Estruturas organógenas nos dolomitos da Formação Capiru (Estado do Paraná). Dusenia, Curitiba, 7 (6): 317. 323.

BIGARELLA, J.J. \& SALAMUNI, R. 1956b. Estudos Preliminares na Série Açungui. VIl. Algumas estruturas singenéticas nos dolomitos da Formação Capiru. Curitiba, Arg. Biol. Tecnol. \{11\}: 197-205.

BIGARELLA, J.J. \& SALAMUNI, R. 1958a. Contibuição à geologia da região sul da Série Açungui (Estado do Paraná)., Săo Paulo, Bol. Paul. Geogr. (29): 1 14.

BIGARELLA, J.J. \& SALAMUNi, R. 1958b. Estudos Preliminares na Série Açungui. VIII. A Formação Votuverava. Curitiba, Instituto de História Natural, 6p. (Boletim de Geologia).

BLACIC, J.D. 1975. Plastic deformation mechanisms in quartz: The effect of water. Tectonophysics (27): 271. 294.

BODNAR, R.J.; REYNOLDS, T.J. \& HUEHN, C.A. 1985. Fluid inclusion systematics in epithermal systems. In: Geology and geochemistry of epithermal systems. Reviews in Economic Geology (2): 73-97.

BOULLIER, A.M.; FRANCELLANORD, C.; DUBESSY, J,; ADAMY, J. \& CHAMPENOIS, M. 1991. Linked fluid and tectonic evolution in the High Himalaya mountain (Nepal). Contr. Miner. Petrol. (107): 358-372.

BOWERS, T.S. \& HELGESON, H.C. 1983. Calculation of the thermodynamic and geochemical consequences of nonideal mixing in the system $\mathrm{H}_{2} \mathrm{O}-\mathrm{CO}_{2}-\mathrm{NaCl}$ on phase relations in geologic systems: Equation of state $\mathrm{H}_{2} \mathrm{O}-\mathrm{CO}_{2}-\mathrm{NaCl}$ fuids at high pressures and temperatures. Geochim. Cosmochim. Acta (47): $1247 \times 1275$.

BROWN, P.E. \& LAMB, W.M. 1989. P.V.T. properties of fluids in the system H2O-CO2-NaCl: new graphical presentations and implications for fluid inclusion studies. Geochim. Cosmochim. Acta (53): 1209-1221.

BUCHER, K. \& FREY, M. Petrogenesis of metamorphic rocks. Springer-Velag, $318 p$.

CAMARA, M.M. 1992. Classificaçäo das principais mineralizaçōes auríferas primárias do Vale do Ribeira. In: CONGR. BRAS. GEOL., 37, São Paulo, 1992. Bol. res. exp. ... São Paulo, SBG, 1992, v.1, p.236.

CAMPANHA, G.A.C. 1991. Tectônica proterozóica no Alto e Médio Vale do Ribeira, Estados de São Paulo e Paraná. São Paulo, 296 p., anexos (Tese de doutoramento. Instituto de Geociências Universidade de São Paulo).

CAMPANHA, G.A.C. 2002. O papel sistema de zonas de cisalhamento trancorrentes na configuração da porção meridional da Faixa Ribeira. São Paulo, 105 p. (Tese de Livre Docência Instituto de Geociências da USP).

CAMPANHA, G.A.C., \& FALEIROS, F.M. 2000. Structural and metamorphic patterns of the Ribeira Lineament, Southeast Brazil. In, 31 International GeologicalCongress, Rio de Janeiro, 2000. 
CAMPANHA G.A.C. \& SADOWSKI G.R., 1999. Tectonics of the Southern Portion of the Ribeira Belt (Apiai Domain). Precambrian Research (98/1): 31-51.

CAMPANHA G.A.C. \& SADOWSKI G.R., 2002. Determinações da deformação finita em rochas metassedimentares da Faixa Ribeira na região de Iporanga e Apiai, SP. Rev. Bras. Geoc. (32/1): 639650 .

CAMPANHA, G.A.C., GIMENEZ FILHO, A., SADOWSKI, G.R. 1994. Tectônica da Faixa Ribeira. In: CONGR. BRAS. GEOL., 38, Baineário de Camboriú, 1978. Bol. Res. Expandidos... Balneário de Camboriú, $S B G, v .1$, p. $271-272$.

CAMPANHA, G.A.C.; GIMENEZ FILFO, A.; CAETANO, S.L.V.; PIRES, F.A.; DANTAS, A.S.L.; TEIXEIRA, A.L.; DEHIRA, L.K. 1985. Geologia das folhas lporanga (SG.22-X-B-V-2) e Gruta do Diabo (SG.22-XB-VI-1), Estado de São Paulo. São Paulo, Contrato IPT/Pró-Minério (IPT. Relatório, 22 352) (inédito).

CAMPANHA, G.A.C.; GIMENEZ FIL.HO, A.; CAETANO, S.L.V.; PIRES, F.A.; DANTAS, A.S.L.; TEIXEIRA, A.L.; DEHIRA, L.K. 1986. Geologia e estratigrafia da região das folhas Iporanga e Gruta do Diabo, Vale do Ribeira, São Paulo. In: CONGRESSO BRASILEIRO de GEOLOGIA, 34, Goiânia, 1986. Anais... Goiânia, SBG. v.2, p.1058-1073.

CAMPANHA, G.A.C.; BISTRICHI, C.A.; ALMEIDA, M.A. de 1987. Considerações sobre a organização litoestratigráfica e evolução tectônica da Faixa de Dobramentos Apiaí. In: SIMPÓSIO SUL. BRASILEIRO de GEOLOGIA, 3, Curitiba, 1987.

CAMPANHA, G.A.C. et al. 1988. Avaliaçäo preliminar das geologia das folhas (em 1:50 000) Taquaral, Mina do Espirito Santo, Ribeiräo Itacolomi, Serra do Aboboral, Jacupiranga (Eldorado Paulista), Rio Guaraú (Barra do Azeite), Rio Turvo (Serra do Aleixo) - Vale do Ribeira, SP. São Paulo, Convênio IPT/SICCT. Pró-Minério. V. 1-4 (IPT. Relatório, 26.863) (inédito).

CAMPANHA, G.A.C., ESCUDERO, O.B., SADOWSKI, G.R. 1993. Análise da geometria e cinemática do Lineamento Ribeira, SP e PR. In: SIMP. NAC. EST. TECT., 4, Belo Horizonte, 1993. Atas... Belo Horizonte, SBG.

CAMPANHA, G.A.C., GIMENEZ FILHO, A., BISTRICHI, C.A. 1995. Geologia da Folha Itararé em 1:250.000. In: SIMP. GEOL. SUDESTE, 4, Águas de São Pedro, 1995. Boletim... Águas de Säo Pedro, SBG, p.111.

CAMPANHA, G.A.C. 2001. Análise da cinemática, nivel crustal e fluxo de fluidos das zonas de cisalhamento da porção menidional da Faixa Apiai. Relatório Final, Processo FAPESP 96/5648-1, 188p., anexos.

CARVALHO, P.I. \& PINTO, E.A. 1937. Reconhecimento geológico da Série Açungui, Brasil. Rio de Janeiro, DNPM. Serviço Geológico e Mineralógico do Brasil, 29p. (DNPM. Boletim 71).

COX, S.F., 1995. Faulting processes at high fluid pressures: An example of fault valve behavior from the Wattle Gully Fault, Vicioria, Australia. Journal of Geophysical Research, 100/n. 87: 12841-12859.

CLOCKE, P.L. \& KESLER, S.E. 1979. The halite trend in hidrothermal solutions. Economic Geology (74): 1823-1831.

DERBY, O.A. 1878. Geologia da região diamantifera da Província do Paraná no Brasil. Arq.Mus. Nac., Rio de Janeiro, (3): $89 \cdot 96$.

EBERT, H.D.; HASUI, Y. \& QUADRE, H. 1988. Aspectos da evolução estrutural do Cinturäo Móvel Costeiro na Regiäo da Mina do Perau, Vale do Ribeira - PR. In: Anais do XXXV Congresso Brasileiro de Geologia, Belém, Pará, V.5: 2318-2331pp.

EGYDIO-SILVA, M. VAUCHEZ, A., BASCOU, J. \& HIPPERTT, J., 2002. High-temperature deformation in the Neoproterozoic transpressional Ribeira belt, southeas Brazil. Tectonophysics.

ELLIOTT, D. 1968. Interpretation of fold geometry from lineation isogonic maps. Journal of Geology (76): 171190. 
FALEIROS, F. M. \& CAMPANHA. G. A. C. 1999. Caracterização Estrutural e Metamórfica do Lineamento Ribeira. In Boletim de Resumos, Simpósio Regional de Geologia, Águas de São Pedro - SP. 1999,São Paulo: Sociedade Brasileira de Geologia - Núcleo São Paulo.

FALEIROS, F. M. \& CAMPANHA, G. A. C. 1999. Caracterização Estrutural e Metamórfica do Lineamento Ribeira. In: SIMP. INT. INIC. CIENT., 7, São Paulo, 1999. Bol. Resumos.

FALEIROS, F. M.; CAMPANHA, G. A. C. \& BELLO, R.M.S. 2000. Termobarometria e caracterização de fluidos associados aos lineamentos Ribeira e Morro Agudo. In: SIMP. INT. INIC. CIENT., 8, São Carlos, 2000. Bol. Resumos.

FASSBINDER, E. 1990. Análise estrutural da falha da Lancinha, Estado do Paraná. São Paulo, 165 p. (Dissertação de Mestrado, Instituto de Geociências USP).

FASSBINDER, E.; FUMAGALL1. E.; FIORI, A.P. 1985. Estudo preliminar sobre os lineamentos tectônicos, intrusões e possiveis mineralizações associadas no Pré-Cambriano paranaense. In: SIMP. SULBRAS. GEOL., 2, Florianópolis, 1985. Atas ..., Florianópolis, SBG. v.1, p.172 - 183.

FASSBINDER, E.; SADOWSKl, G.R.; FIORI, A.P. 1992. Análise estrutural da Falha da Lancinha no Estado do Paraná. In: CONGR. BRAS. GEOL., 37, São Paulo, 1992. Bol. Res. Expandidos... São Paulo, $S B G, v .2$, p. 362 .

FASSBINDER, E.; SADOWSKI, G.R.; FIORI, A.P. 1994. Modelo de Riedel aplicado no Lineamento Lancinha, no Estado do Paraná. Bol. Paran. Geoc. (42): 173-184.

FASSBINDER, E. 1996. A unidade Água Clara no contexto do Grupo Açungui: um modelo transpressivo de colisão obliqua no Neoproterozóico Paranaense. São Paulo, 207p. (Tese de Doutorado, Instituto de Geociências da USP).

FIORl, A. P. 1985. Aplicação do modelo de cisalhamento simples na análise da deformação de alguns granitos paranaenses. Bol. Paran. Geoc. (36): 31-40, Curitiba.

FIORI, A. P. 1985. Avaliação preliminar do deslocamento dúctil das falhas de Lancinha e Morro Agudo no Estado do Paraná. Bol. Paran. Geoc. (36): 15-30, Curitiba.

FIORI, A. P. 1990. Tectônica e estratigrafia do Grupo Açungui à norte de Curitiba. São Paulo, Universidade de São Paulo, 261p. (Tese de Livre Docência - Instituto de Geociências da USP).

FIORI, A. P. 1993. O Sistema de Cavalgamento Açungui (PR). Geociências, São Paulo, (12/1): 187-208.

FIORI, A. P. 1997. Introdução à análise da deformaçâo. Curitiba, Editora UFPR 249 p.

FOREMAN, J.L. \& DUNE, W.M. 1991. Condition of vein formation in the southern Appalachian foreland: constraints from vein geometries and fiuid inclusion. J. Struct. Geol. (13): 1173-1183.

FUETTEN, F., 1997. A computer controlled rotating polarizer stage for the petrographic microscope. Computers and Geosciences (23): 203-208.

FUZIKAWA, K. 1985. Inclusōes fluidas: métodos usuais de estudo e aplicaçōes. In: Contribuiçöes à Geologia e à Petrologia. Boletim Especial, Nicleo de Minas Gerais, SBG. pp. 29.30.

GEOFREY, D.R. \& SANTOS, T.D. de S. 1942. Nota sobre a geologia de Apiaí. Min. Met., São Paulo, $(6 / 33): 109-110$.

GOLDSTEIN, R.H. \& REYNOLDS, T.J. 1994. Systematics of fluid inclusions in diagenetic minerals. Society for Sedimentary Geology. pp.

HARA, I.; PAULISTSCH, P.; HIDE, K. \& TAKEDA, K. 1976. A geometric relationship between quartz c axis fabrics produced in axial and ortorhombic strain states. Neves Jahrb. Mineral. Abstract (127): 84-96.

HASUI, Y. \& SADOWSKI, G.R. 1976. Evolução geológica do pré-Cambriano na regiăo sudeste do Estado de São Paulo. Rev. Bras. Geoc. (6/3): 182-200.

HOBBS, B.E.; MEANS, W.D.; WILLIANS, P.F. 1976. An outline of structural geology. New York, John Willey. 
HODGKINGS, M.A. \& STEWART, K.G. 1994. The use of fluid inclusion to constrain fault zone pressure, temperature and kinematic history: an example from the Alpi Apuane, Italy. Journal od Structural Geology (16): 85-96.

HOLLISTER, L.S. 1981. Information intrinsically available from fluid inclusions, In: HOLLISTER, L.S. \& CRAWFORD, M.L. (Eds) Fluid Inclusion: Aplications to Petrology, Calgary, Mineralogical Association of Canadá, 1-12 (Short Course, handbook, v.6).

JOY, S. \& SAHA, D. 1998. Influence of micaceous impurity on dinamically recrystallized quartz c-axis fabric in L-S tectonites from the Singhbhum Shear Zone and its footwall, Eastern India. Journal of Structural Geology (20/11): 1509-1520.

LAUNEAU, P. \& CRUDEN, A.R., 1998. Magmatic fabric acquisition mechanisms in a syenite: resultas of a combined anisotropy of magnétic suscetibility and image analysis study. Journal of Geophysical Research (103): 5067-5089.

LAUNEAU, P. \& ROBIN, P.Y.F. (submetido). Determination of fabric and strain ellipsoids from measured sectional ellipses - Implementation and applications.

LAUNEAU, P.; CRUDEN, A.R. \& BOUCHEZJ.L., 1994. Mineral recognition in digital images of rock: a review approach using multichannel classification. The Canadian Mineralogist (32): 919-933.

LIOU, J.G.; KUNIYOSHI, S. \& ITO, K. 1974. Experimental studies of the phase relations between greenschist and amphibolite in a basaltic system. Am. J. Sci. (274): 613.632.

LISTER, G.S. 1977. Discussion: crossed-girdle C-axis in quartzites plastically deformed by plane strain and progressive simple shear. Tecnophysics (39): 51-54.

LISTER, G.S. \& DORNSIEPEN, U.F. 1982. Fabric transitions in the Saxony Granulite Terrain. Journal of Structural Geology (4): 81-92.

LISTER, G.S. \& HOBBS, B.E. 1980. The simulation of fabric development during plastic deformation and it's application to quartzite: fabric transitions. Journal of Structural Geology (2): 355-370.

LISTER, G.S. \& SNOKE, A.W. 1984. S.C Mylonites. Journal of Structural Geology (6/6): 617-638.

LISTER, G.S. \& WILLIANS, P.F. 1979. Fabric development in shear zones: theoretical controls and observed phenomena. Journal of Structural Geology (1): 283-79.

MARINI, O.J.; TREIN, E. \& FUCK, R.A. 1967. O Grupo Açungui no Estado do Paraná. Bol. Paran. Geoc., Curitiba (23-25): 43-104.

MARTINS, G.R. 1938. Recursos minerais do Vale do Ribeira de Iguape. Min. Metal, São Paulo, 3:13.

MELLO, I.S. 1995. Geologia e aspectos metalogenéticos do Maciço Itaoca, Vale do Ribeira, SP e PR. Säo Paulo, Universidade de São Paulo, $168 \mathrm{p}$. (Tese de Doutorado - instituto de Geociências da USP).

MELLO, I.S. \& BITTENCOURT, J.S., 1998. Geologia e gênese das mineralizações associadas ao maciço de Itaoca, Vale do Ribeira, SP e PR. Revista Brasileira de Geociências (28/3): 269-284.

METAL MINING AGENCY of JAPAN. Japan international Cooperation Agency. 1981. Report on geological survey of Anta Gorda, phase 1. Convênio DNPM/MMAJ/JICA.

METAL MINING AGENCY of JAPAN. Japan international Cooperation Agency. 1982. Report on geological survey of Anta Gorda, phase 2. Convênio DNPM/MMAJ/JICA.

METAL MINING AGENCY of JAPAN. Japan International Cooperation Agency. 1983. Report on geological survey of Anta Gorda, phase 3. Convênio DNPM/MMAJ/JICA.

MORAES REGO, L.F. de 1933. Contribuição ao estudo das formaçöes Pré-devonianas de São Paulo. São Paulo, Instituto Astronômico e Geofísico de São Paulo, $60 \mathrm{p}$.

MORGENTAL, A., et al. 1975. Projeto Sudelpa, relatório final, geologia. São Paulo, convênio SUDELPACPRM, $18 \mathrm{~V}$. 
NADEN, J. \& SHEPHERD, T.J. 1989. Role of methane and carbon dioxide in gold deposition. In: NATURE, (342): 793-795.

NEWTON, R.C.; ARANOVICH, L.Ya.; HANSEN, E.C. \& VANDENHEUVEL, B.A. 1998. Hypersaline fluids in Precambrian deep-crustal metamorphism. Precambriam Research (91): 41-63.

NICOLAS, A., Principles de tectonique. Masson ed. 196p.

NITSCH, K.H. 1970. Experimentelle Bestimmung der oberen Stabilitätsgrenze von Stilpnomelan. Forstschr Mineral 47, Beih (1): 48-49.

NOGUEIRA, S.A.A. 1990. Estudo das mineralizaçöes filoneanas auriferas do depósito de Piririca, Vale do Ribeira, SP. São Paulo, 91p. (Dissertação de Mestrado, Instituto de Geociências - USP).

OLIVEIRA, E.P. 1916. Geologia do Estado do Paraná. Bol.Min. Agric.Ind.Com., Rio de Janeiro, (5/1): 77-143.

OLIVEIRA, E.P. 1925. Mapa geológico do Estado do Paraná, escala 1:1000 000. Rio de Janeiro, DNPM. Serviço Geológico e Mineralógico do Brasil.

OLIVEIRA, E.P. 1927. Geologia e recursos minerais do Estado do Paraná. Rio de Janeiro, DNPM. Serviço Geológico e Mineralógico do Brasil, 172 p. (Monografia, 6).

PASSCHIER, C.W. \& TROUW, R.A.J. 1996. Microtectonics. Berlim Heidelberg, Springer-Verlag, 289p.

PERROTA, M.M. 1996. Potencial aurifero de uma regiāo no Vale do Ribeira, São Paulo, estimado por modelagem de dados geológicos, geofísicos, geoquímicos e de sensores remotos num sistema de informações geográficas. Säo Paulo, 149p. (Tese de Doutoramento, Instituto de Geociências Universidade de São Paulo).

PETRI, S. \& SUGUIO, K. 1969. Sobre os metassedimentos do extremo sul do Estado de Säo Paulo. Säo Paulo, convênio USPIDAEE (Publicação especial).

PIRES, F.A. 1988. Uma nova concepçăo para os ambientes do Grupo Açungui, na regiäo de lporanga e Apiaí, sul de São Paulo. In: CONGRESSO BRASILEIRO de GEOLOGIA, 35. Belém, 1988. Anais... Belém, SBG. v.2, p.606-616.

PIRES, F.A. 1990. Análise paleoambiental e estratigráfica de seqüências metassedimentares (Grupo Açungui), na região de lporanga e Apiaí SP. São Paulo. (Dissertação de Mestrado. Instituto de Geociências - USP).

PIRES, F.A.; ALARSA, M.; AMARAL, G.; PETRI, S. 1990. Estruturação das seqüências Betari e FurnasLajeado (Grupo Açungui), na regiäo de lporanga - São Paulo. in: CONGRESSO BRASILEIRO de GEOLOGIA, 36. Natal, 1990. Boletim de Resumos. Natal, SBG. p.274.

PRICE, G.P. 1985. Preferred orientations in quartzites. In: Wenk, H.R. (ed) Preferred Orientations in Deformed Metals and Rocks: an Introduction to Modern Texture Analysis. Academic Press, Orlando, $385-406$.

RAMBOZ, C.; PICHAVANT, M. \& WEISBROD, A. 1982. Fluid immiscibility in natural processes: use and misure of fuid inclusion data. Chemical Geology (37): 29-48.

RAMSAY, J.G. 1967. Folding and fracturing of rocks. McGraw-Hill Book Co., New York, 568 p.

RAMSAY, J.G. \& GRAHAM, R.H. 1970. Strain variation in shear belts. Can. J. Earth Sci. (7): 786-813.

RAMSAY, J.G. \& WOOD, D.S. 1973. The geometric effects of volume change during deformational processes. Tectonophysics (16): 263-277.

RAMSAY, J.G. \& HUBER, M.l. 1983. The techniques of modern structural geology. Volume 1: Strain Analysis. New York, Academic Press 307p.

RAMSAY, 3.G. \& HUBER, M.I. 1987. The techniques of modern structural geology. Volume 2: Folds and Fractures. Academic Press 700p.

RAMSAY, J.G. \& LISLE, R.J. 2000. The techniques of modern structural geology, Volume 3: Applications of Continuum Mechanics in Structural Geology. Academic Press, London 560p. 
RAMSAY, J.G. 1980. Shear zone geometry: a review. Journal of Structural Geology, 2(1/2): 83-99.

REIS NETO, J.M. 1994. Faixa ltaiacoca: registro de uma colisão entre dois blocos continentais no Neoproterozóico. São Paulo, Universidade de Săo Paulo, 235p. (Tese de Doutorado - Instituto de Geociências da USP).

ROBERT, F., BOULLIER, A-M \& FIRDAOUS, K., 1995. Gold-quartz veins in metamorphic terranes and their bearing on the role of fluids in fauting. Journal of Geophysical Research, 100/n. B7: 12861-12879.

ROBIN, P.Y. F. Determination of fabric and strain ellipsoids from measured sectional ellipses ... Theory. Journal of Structural Geology (in press).

ROBIN, P.-Y.F. \& CRUDEN, A.R. 1994. Strain and vorticity patterns in ideally ductile transpression zones. Journal of Structural Geology (6): 447-466.

ROEDDER, E. 1984. Fluid Inclusions. Review in Mineralogy. v. 12, RIBBE, P.H. (ed). Mineralogical Society of America, 646p.

SADOWSKI, G.R. 1980. Brazilian precambrian ductile shear belts. XXVI Congr.Inter.Geol, sessão nr.5, tectonica, Bol.Res., v.1, p.385.

SADOWSKI, G.R. 1983. Sobre a geologia estrutural de cinturöes de cisalhamento continentais. São Paulo. 108p. (Tese de Livre Docência, Instituto de Geociências USP).

SADOWSKI, G.R. 1984 . Estado da arte do tema: Geologia estrutural de Grandes Falhamentos. In: CONG.BRAS.GEOL.,33, Rio de Janeiro, Anais:SBG, p.1767-1793.

SADOWSKi, G.R. 1991. A megafalha de Cubatäo no Sudeste Brasileiro. Bol. /G-usp, Sér. Cient. (22): 15 - 28. SANDERSON, D.J. \& MARCHINI, W.R.D., 1984. Transpression. Journal of Structural Geology, (6): 449.458.

SCHIMID, S. M. \& CASEY, M. 1986. Complete fabric analysis of some commonly observed quartz C-axis patterns in mineral and rock deformation: Laboratory Studies. The Paterson Volume. Geophisical Monograph, 36 .

SHEPHERD, T.J.; RANKIN, A.H.; ALDERTON, D.H.H. 1985. A practical guide to fluid inclusions studies. Blackie and Son Ltda, New York, 239p.

SIBSON, R. H. 1977. Faut rocks and fault mechanisms. J. Geol. Soc. London (133):191-213.

SIBSON, R. H., J. MOORE and A. H. RANKIN, 1975, Seismic pumping - a hydrothermal fluid transport mechanism, Journal Geol. Soc. London (131): 653-659.

SIBSON, R.H., ROBERT, F. \& POULSEN K.H. 1988. High-angle reverse faults, fluid pressure cycling, and mesothermal gold-quartz deposits. Geology (16): 551-555.

SILVA, A.T.S.F. \& ALGARTE, J.P. 1981a. Contribuição à geologia da Sequencia Turvo-Cajati entre o Rio Pardo e Pariquera-Açu, estado de São Paulo. 1 - Litologia e Petrografia. Atas do $3^{\circ}$ Simpósio Regional de Geologia, SBG, Curitiba, PR, volume 1: 109-119.

SILVA, A.T.S.F. \& ALGARTE, J.P. 1981b. Contribuição à geologia da Seqüência Turvo-Cajati entre o Rio Pardo e Pariquera-Açu, estado de Säo Paulo. II - Estrutura, metamorfismo e evoluçäo geotectônica. Atas do $3^{\circ}$ Simpósio Regional de Geologia, SBG, Curitiba, PR, volume 1: 121-132.

SILVA, A.T.S.F. et al. 1977. Projeto Santos --Iguape. Relatório final de geologia. Säo Paulo, Convênio DNPM/CPRM.

SiLVA, A.T.S.F. et al. 1978. Geologia integrada das tolhas iguape e Cananéia. In: Congr. Bras. Geol. 30 , Recife, 1978. Anais ... Recife, SBG, v1, p. 222.235.

SOARES, P.C. 1987. Seqüencias tectono-sedimentares e tectônica deformadora no centro-oeste do escudo paranaense. In: Simp. Sul-Brasileiro de Geol., 3. Curitiba, 1987. Atas ... Curitiba, SBG, v2: 743-771.

SRIVASTAVA, D.C. \& ENGELDER, T. 1991. Fluid evolution history of brittle ductile shear zones in hanging wall of Yellow Spring thrust, Vailey and Ridge Province, Pennsysvania, USA. Tectonophysics (198): 23-34. 
TIKOFF, B. \& TEYSSIER, C. 1994. Strain modeling of displacement-field partitioning in transpressional orogens. Journal of Structural Geology (16/11): 1575-1588.

TOURET, J.L.R. 1985. Fitid regime in southern Norway, the record of fluid inclusions. In: Tobi, A.C., Touret, J.L.R. (eds), The Deep Proterozoic Crust in the North Atlantic Provinces. Reidel, Dordrecht, pp. 517. 549.

TULLLIS, J.; CHRISTIE, J.M. \& GRIGGS, D.T. 1973. Microstructure and preferred orientation of experimentally deformed quartzites. Geological Society of America Bulletin (86): 632-638.

TURNER, F.J. \& WEISS, L.E. 1963. Structural analysis of metamorphic tectonites. New York, McGraw Hill. $545 p$.

VASCONCELOS, C.S.; YAMATO, A.A.; DEHLER, N.M.; LOPES Jr, I. 1999. Projeto Jacupiranga - Rio Guaraú, Estado de São Paulo. São Paulo, Convênio CPRM / Secretaria de Energia do Governo do Estado de São Paulo (inédito).

VOLL, G. 1976. Recristallization of quartz, biotite and feldspars from Ersfeld to the Leventina nappe, Swiss Alps, and its geological significance. Schweiz Mineral. Petrogr. Mitt. (56): 641-647.

VOLL, G. 1980. Ein Querprofil surch die Schweizer Alpen von Vierwaldstaetter See zur Wurzelzone Strukturen und ihre Entwicklung durch Deformationsmechanismen wichtinger Mineral. N. Jb. Geol. Palaeont. Abh (160): 321-335.

VROLUUK, P. 1987. Tectonically driven fluid flow in the kodiak accretionary complex, Alaska. Geology (15): 466-469.

XU, G. 1997. Fluid inclusions in crack-seal veins at Dugald River, Mount Isa Inlier: implications for palaeostress states and deformation conditions during orogenesis. Journal of Structural Geology (19/11): 1359-1368.

YONKEE, W.A.; PARRY, W.T.; BRUHN, R.L.; \& CASHMAN, P.H. 1989. Thermal models of thrust faulting: Constraints from fluid-inclusion observations, Willard thrust sheet, Idaho-Utah-Wyoming thrust belt. Bull. Geol. Soc. Am. (101): 304-313.

WAHLSTROM, E.E. 1969. Optical crystallography (4th ed.): John Wiley \& Sons, New York, 489p. 


\section{AGRADECIMENTOS}

O autor expressa seu agradecimento a todas as pessoas que tiveram participação direta ou indireta na elaboração deste trabalho.

Ao Prof. Dr. Ginaldo Ademar da Cruz Campanha pela orientação e apoio em todas atividades deste trabalho, bem como pelo incentivo dado desde a época da graduação.

À Dra. Rosa Maria da Silveira Bello pela orientação e participação de maneira interessada e cuidadosa nos estudos de inclusões fluidas.

Aos meus irmãos Rodrigo Meira Faleiros e Marcelo Meira Faleiros que participaram dos primeiros trabalhos de campo.

Aos amigos da pós-graduação do Instituto de Geociências da USP Sergio Willians de Oliveira Rodrigues, Carlos Henrique Grohmann de Carvalho, Leonardo Fadel Cury, Luciana Pascarelli, Werner Weber, Thiago da Rocha Karniol, pelas discussões teóricas, entre outras, que muito contribuíram para a conclusão deste trabalho. Aos demais amigos da geologia que de certa forma tiveram participação no desenvolvimento deste trabalho André Oliveira Sawakuchi, Thiago Bastos Bonás, Paula Garcia do Amaral, Eduardo Yamamoto, Lucelene Martins, Ivan Delfini Neves, Diana Maria Jimenez, Marcia Gomes da Silva, José Coelho de Araújo Filho. Agradecimento especial para Sergio Willians que, além de tudo, participou da etapa final de campo.

Aos colegas de sala William Sallun Filho, Francisco William da Cruz Júnior e Ivanety Pereira.

Aos professores Dr. Carlos José Archanjo e Dr. José Moacyr Vianna Coutinho pelo incentivo e apoio na aplicação dos métodos de obtenção de tramas de orientação preferencial de forma e cristalográfica, respectivamente. Ao professor Dr. Caetano Juliani por discussões teóricas.

Aos professores Dr. Roberto Perez Xavier (Unicamp) e Dr. Kazuo Fuzikawa (CDTN-CNEN) pelo apoio na realização de análises por espectroscopia Raman em inclusöes fluidas.

Ao professor Dr. Ian McReath pela correção do Abstract.

Aos funcionários do Instituto de Geociências da USP, em especial ao Tadeu Caggiano (Setor de Apoio aos Colegiados), à Ana Cristina Machado Rodríguez (LIG), ao Erickson Zanon (Seção Técnica de Informática) e ao pessoal da Seçăo de Pós* graduação, da Gráfica, do Setor de Laminação e da Biblioteca.

Aos funcionários da Divisão de Geologia do IPT pela disponibilização de fotos aéreas e lâminas petrográficas utilizadas nas etapas iniciais de desenvolvimento deste trabalho. 
Ao pessoal da Divisão de Dasonomia do Instituto Florestal, em especial aos funcionários Marco Aurélio e Mônica Pavão, pelo fornecimento de cartas topográficas em formato digital.

À FAPESP pelo auxilio financeiro referente à bolsa de estudos, processo 01/00199 4. 


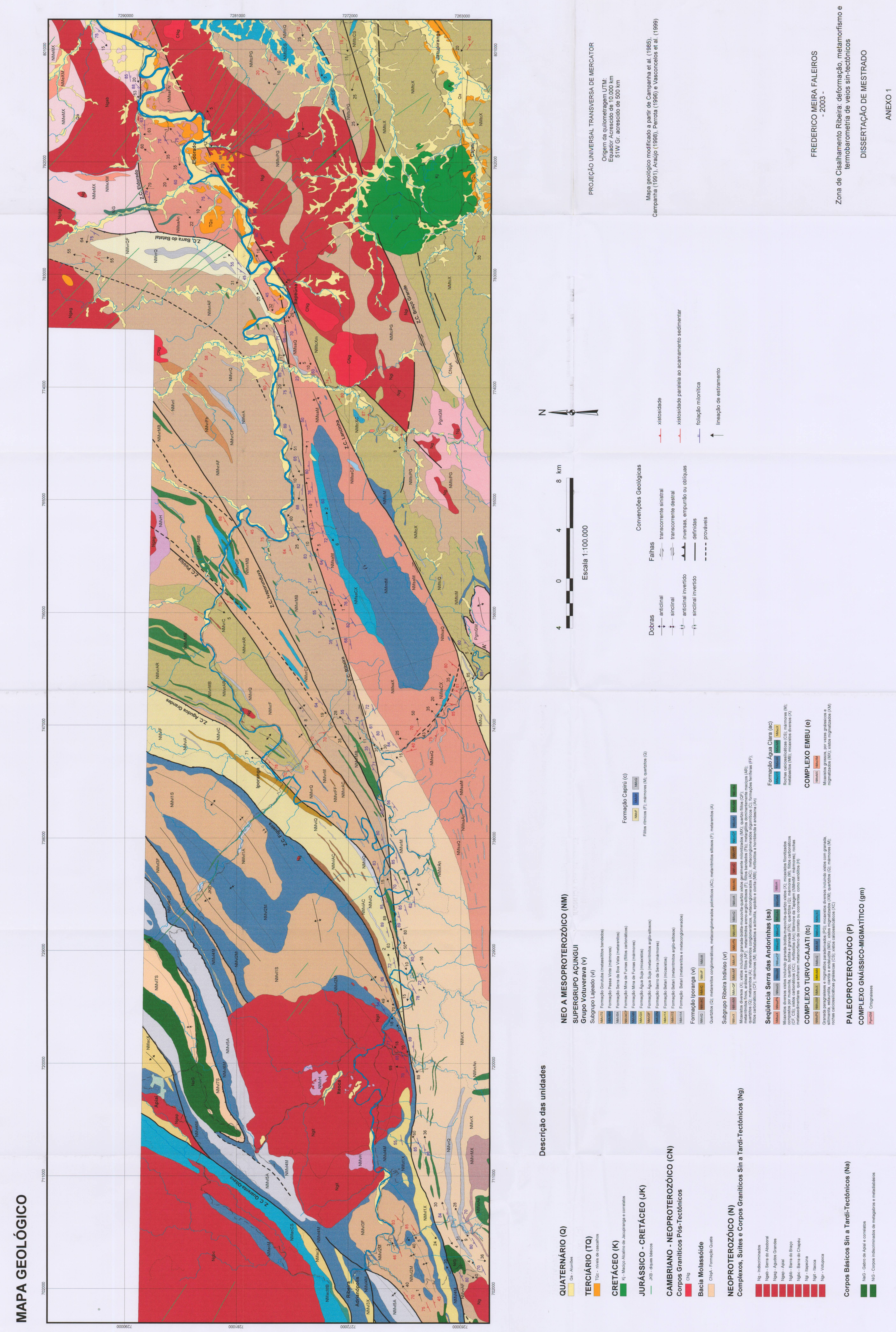




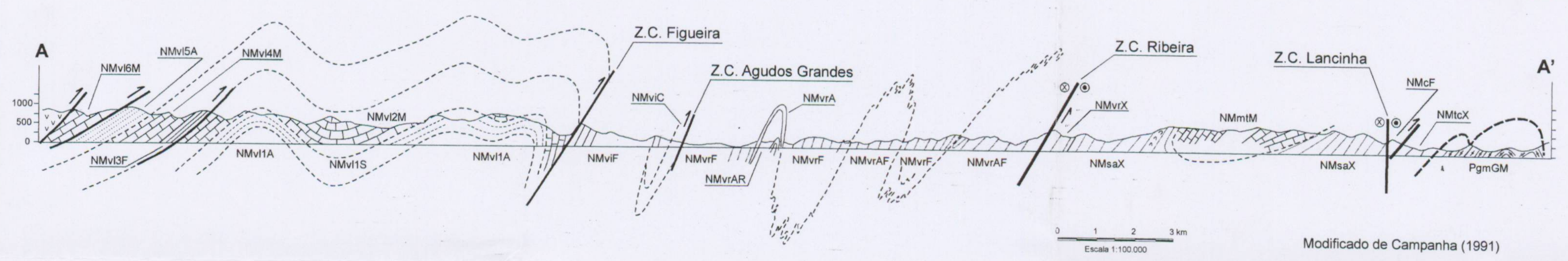

\section{SUBGRUPO LAJEADO}

NMvl6M - Formação Passa Vinte (mármores)

NMv15A - Formação Serra da Boa Vista (metarenitos)

NMv14M - Formação Mina de Furnas (mármores)

NMvl3F - Fomaçăo Agua Suja (filitos)

(mista (mármores)

NMvl1A - Formação Betari (metarenitos)

\section{FORMAÇÃO IPORANGA}

NMviF - filitos

$\mathrm{NMviC}$ - conglomerados

\section{SUBGRUPO RIBEIRA}

NMvrAR - metargilitos

MVrA - metarenito

NMVIF - filitos (metarritmitos)

NMvrAF - ardósias e metarritmitos

MvrX - micaxistos

\section{SEQÜÊNCIA SERRA DAS ANDORINHAS}

NMmtM - Mármore da Tapagem

\section{FORMAÇÃO CAPIRU}

NMCF - filitos

COMPLEXO TURVO CAJATI

$\mathrm{NMtcX}$ - micaxistos

COMPLEXO GNÁISSICO-MIGMATÍTICO

PGmGM - ortognáisses
Convenções Geológicas

— Falha definida

-...- Contatos inferidos

$\longrightarrow$ Componente de movimentação inversa ou norma

$\otimes$ - Componente de movimentação direcional destral predominante

\section{Perfil Geológico}

Zona de Cisalhamento Ribeira: deformação, metamorfismo e termobarometria de veios sin-tectônicos

DISSERTAÇÃO DE MESTRADO

FREDERICO MEIRA FALEIROS

-2003 -

ANEXO 2 


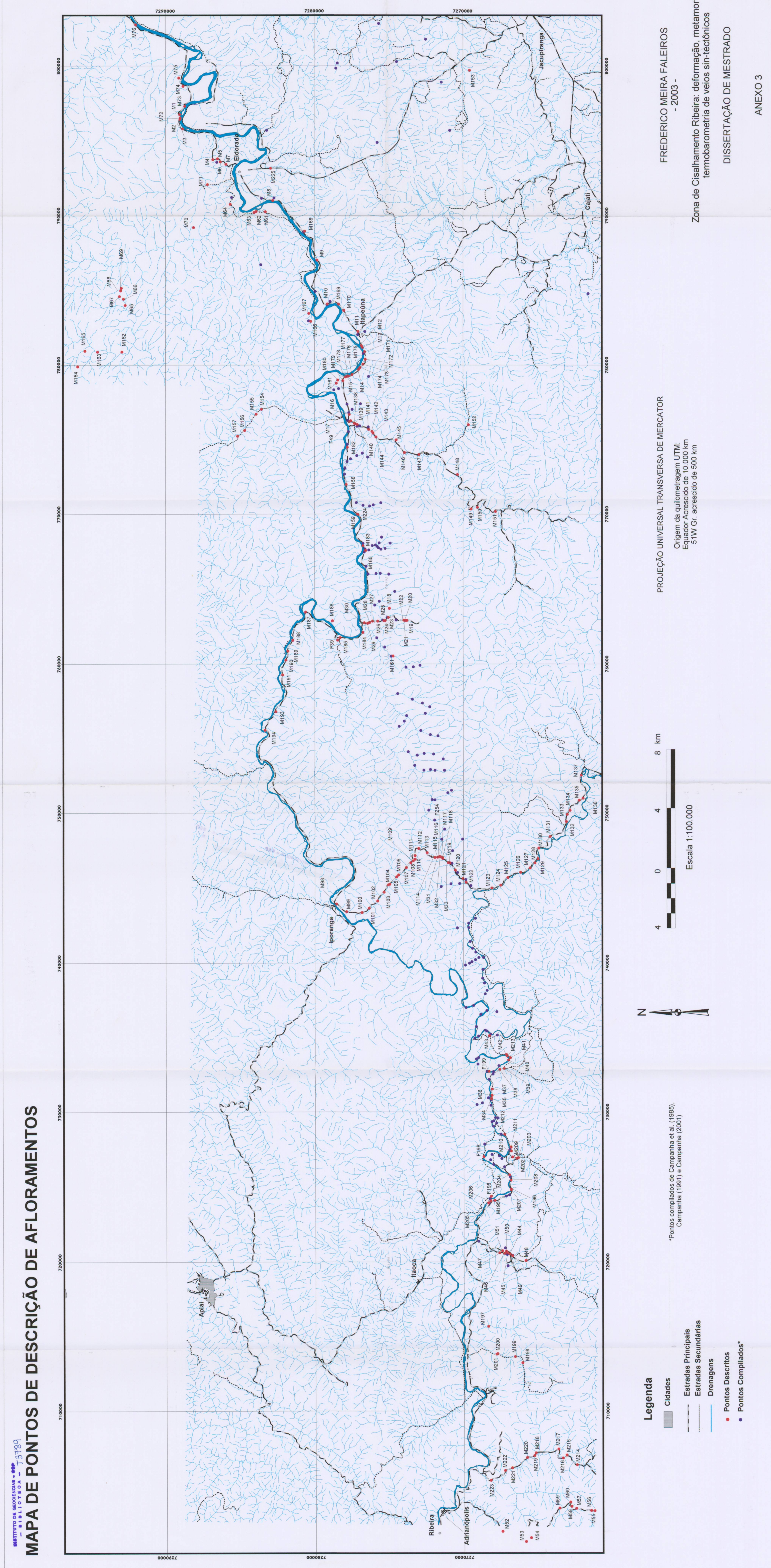

